\section{Literature and Information Related} to the Natural Resources of the North Aleutian Basin of Alaska

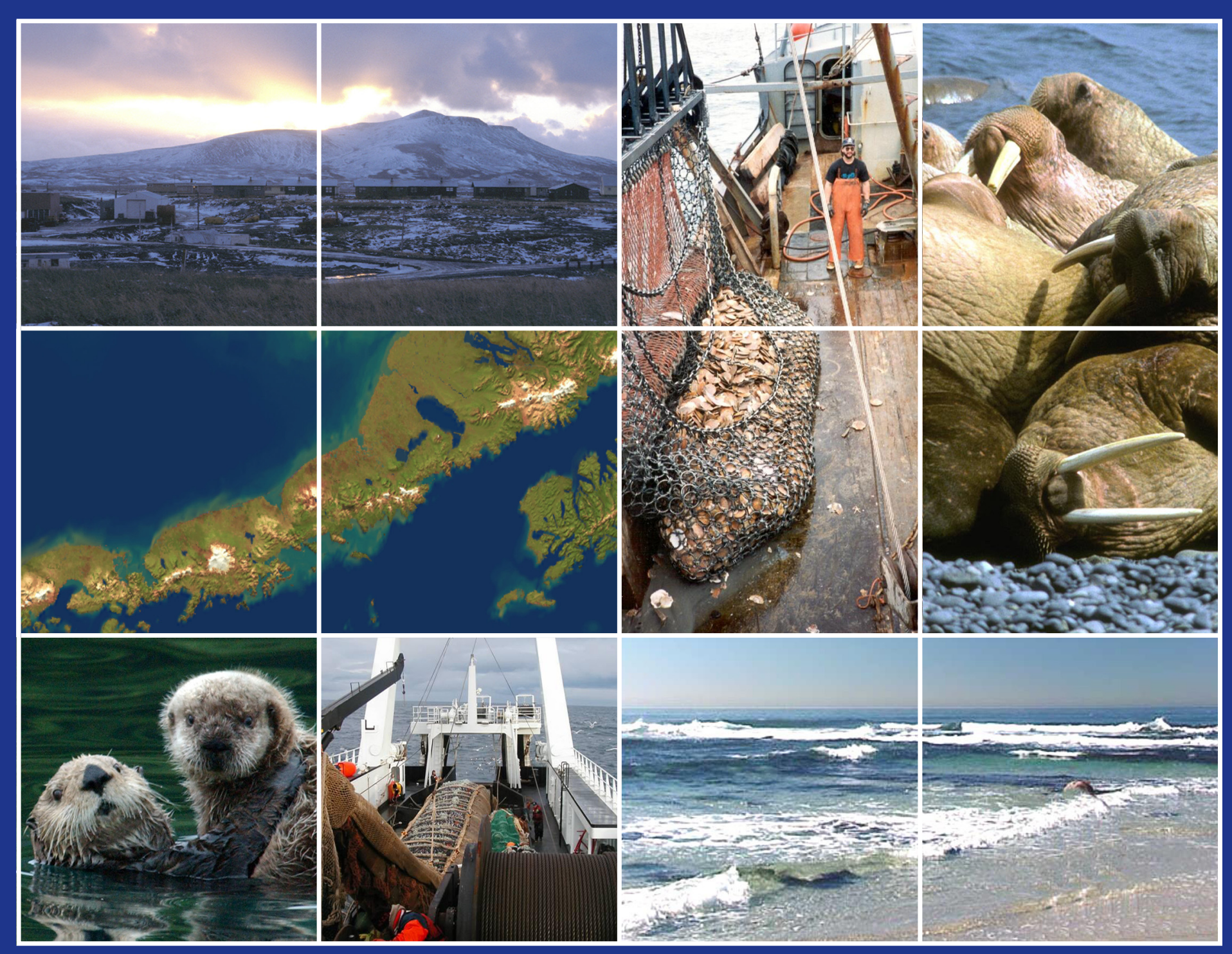

Minerals Management Service - Alaska Region U.S. Department of the Interior

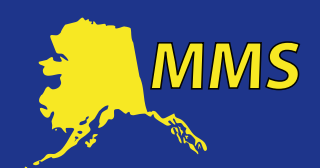

Argonne National Laboratory

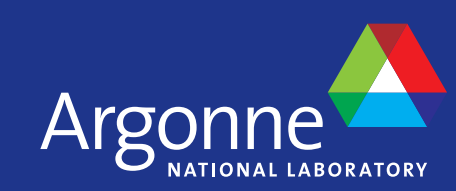


About Argonne National Laboratory

Argonne is a U.S. Department of Energy laboratory managed by UChicago Argonne, LLC

under contract DE-AC02-06CH11357. The Laboratory's main facility is outside Chicago,

South Cass Avenue, Argonne, Illinois 60439. For information about Argonne,

\section{Disclaimer}

This report was prepared as an account of work sponsored by an agency of the United States Government. Neither the United States Government nor any agency thereof, nor UChicago Argonne, LLC, nor any of their employees or officers, makes any warranty, express product, or procoess disclosed, or reperesents that its use would not infringe privately owned rights. Referennce herein to any specific commercial product, process, or service by trade name, trademark, manufacturer, or otherwise, does not necessarily constitute or imp document authors expressed herein do not necessarily state or erfect those of the United States Government or any agency thereof document authors expressed herein do not necessarlil stat
Argonne National Laboratory, or UChicago Argonne, LLC. 


\author{
prepared by
}

Environmental Science Division

Argonne National Laboratory

Argonne, Illinois

\author{
for \\ U.S. Department of Interior \\ Minerals Management Service \\ Alaska Outer Continental Shelf Region \\ Anchorage, Alaska
}

MMS OCS 2007-066

December 2007 


\section{CONTENTS}

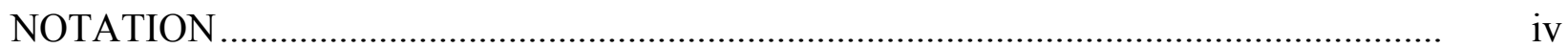

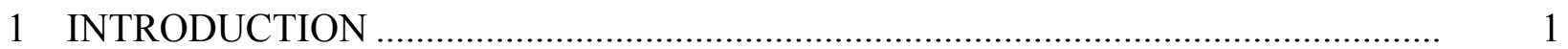

2 OCEANOGRAPHY AND ECOSYSTEMS ………................................................ 3

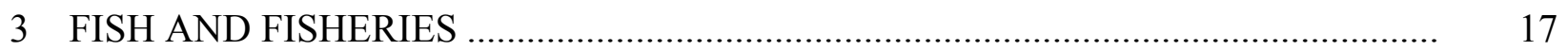

4 SEABIRDS, SHOREBIRDS, AND WATERFOWL …………………………............. 33

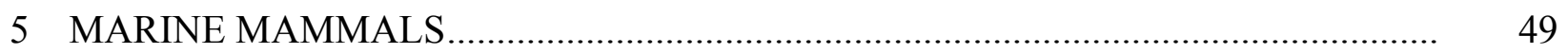

6 SOCIOECONOMICS AND SUBSISTENCE ………...............................................

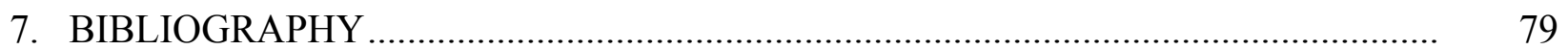

7.1. Oceanography and Ecosystems...................................................................... 79

7.2. Fish and Fisheries ............................................................................................... 89

7.3. Seabirds, Shorebirds, and Waterfowl............................................................ 102

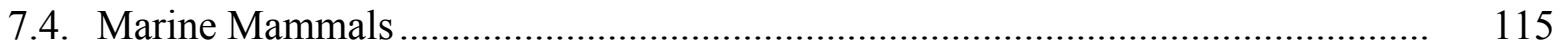

7.5. Socioeconomics and Subsistence................................................................ 134

\section{TABLES}

1 Publications from 1996 to 2006 Related to Oceanography and Ecosystems of the North Aleutian Basin

2 Publications from 1996 to 2006 Related to Fish and Fisheries of the North Aleutian Basin

3 Publications from 1996 to 2006 Related to Seabirds, Shorebirds, and Waterfowl of the North Aleutian Basin

4 Publications from 1996 to 2006 Related to Marine Mammals of the North Aleutian Basin 


\section{NOTATION}

The following is a list of the acronyms, initialisms, and abbreviations used in this document.

$\begin{array}{ll}\text { ADFG } & \text { Alaska Department of Fish and Game } \\ \text { ADNR } & \text { Alaska Department of Natural Resources } \\ \text { AMAP } & \text { Arctic Monitoring and Assessment Programme } \\ \text { Argonne } & \text { Argonne National Laboratory } \\ \text { ARRT } & \text { Alaska Regional Response Team } \\ \text { AYK-SSI } & \text { Arctic Yukon Kuskokwim Sustainable Salmon Initiative } \\ \text { BESIS } & \text { Bering Sea Impact Study } \\ \text { BEST } & \text { Bering Ecosystem Study } \\ \text { BLM } & \text { Bureau of Land Management } \\ \text { CIFAR } & \text { Cooperative Institute for Arctic Research } \\ \text { CFEC } & \text { Commercial Fisheries Entry Commission } \\ \text { DOC } & \text { U.S. Department of Commerce } \\ \text { DOD } & \text { U.S. Department of Defense } \\ \text { DOI } & \text { U.S. Department of Interior } \\ \text { EIS } & \text { environmental impact statement } \\ \text { ESA } & \text { Endangered Species Act } \\ \text { FWS } & \text { U.S. Fish and Wildlife Service } \\ \text { GIS } & \text { geographic information system } \\ \text { IAI } & \text { Impact Assessment, Inc. } \\ \text { MMPA } & \text { Marine Mammal Protection Act } \\ \text { MMS } & \text { Minerals Management Service } \\ \text { NMFS } & \text { National Marine Fisheries Service } \\ \text { NOAA } & \text { National Oceanographic and Atmospheric Administration } \\ \text { NPRB } & \text { North Pacific Research Board } \\ \text { OCS } & \text { Outer Continental Shelf } \\ \text { UBC } & \text { University of British Columbia } \\ \text { USGS } & \text { U.S. Geological Survey } \\ \end{array}$




\title{
LITERATURE AND INFORMATION RELATED TO THE NATURAL RESOURCES OF THE NORTH ALEUTIAN BASIN OF ALASKA
}

\author{
prepared by
}

\author{
Elisabeth A. Stull, Ihor Hlohowskyj, and Kirk E. LaGory \\ Environmental Science Division \\ Argonne National Laboratory \\ Argonne, Illinois
}

\section{INTRODUCTION}

The North Aleutian Basin Planning Area of the Minerals Management Service (MMS) is a large geographic area with significant natural resources. The Basin includes most of the southeastern part of the Bering Sea Outer Continental Shelf, including all of Bristol Bay. The area supports important habitat for a wide variety of species and globally significant habitat for birds and marine mammals, including several federally listed species. Villages and communities of the Alaska Peninsula and other areas bordering or near the Basin rely on its natural resources (especially commercial and subsistence fishing) for much of their sustenance and livelihood. The offshore area of the North Aleutian Basin is considered to have important hydrocarbon reserves, especially natural gas.

In 2006, the MMS released a draft proposed program, Outer Continental Shelf Oil and Gas Leasing Program, 2007-2012 and an accompanying draft programmatic environmental impact statement (EIS). The draft proposed program identified two lease sales proposed in the North Aleutian Basin in 2010 and 2012, subject to restrictions. The area proposed for leasing in the Basin was restricted to the Sale 92 Area in the southwestern portion. Additional EISs will be needed to evaluate the potential effects of specific lease actions, exploration activities, and development and production plans in the Basin. A full range of updated multidisciplinary scientific information will be needed to address oceanography, fate and effects of oil spills, marine ecosystems, fish, fisheries, birds, marine mammals, socioeconomics, and subsistence in the Basin.

Scientific staff at Argonne National Laboratory were contracted to assist MMS with identifying and prioritizing information needs related to potential future oil and gas leasing and development activities in the North Aleutian Basin. Argonne focused on three related tasks: (1) identify and gather relevant literature published since 1996, (2) synthesize and summarize the literature, and (3) identify and prioritize remaining information needs. To assist in the latter task, MMS convened the North Aleutian Basin Information Status and Research Planning Meeting (the Planning Meeting) in Anchorage, Alaska, from November 28 through December 1, 2006. 
That meeting and its results are described in Proceedings of the North Aleutian Basin Information Status and Research Planning Meeting (the Planning Meeting report) ${ }^{1}$.

Citations for recent literature (1996-2006) to support an assessment of the impacts of oil and gas development on natural, cultural, and socioeconomic resources in the North Aleutian Basin were entered in a database. The database, a series of Microsoft Excel spreadsheets with links to many of the reference materials, was provided to MMS prior to the Planning Meeting and was made available for participants to use during the meeting. Many types of references were identified and collected from the literature, such as workshop and symposium proceedings, personal web pages, web pages of government and nongovernmental organizations, EISs, books and articles reporting research results, regulatory documents, technical reports, newspaper and newsletter articles, and theses and dissertations. The current report provides (1) a brief overview of the literature; (2) descriptions (in tabular form) of the databased references, including geographic area covered, topic, and species (where relevant); (3) synopses of the contents of the referenced documents and web pages; and (4) a full citation for each reference.

At the Planning Meeting, subject matter experts with research experience in the North Aleutian Basin presented overviews of the area's resources, including oceanography, fish and shellfish populations, federal fisheries, commercial fishery economics, community socioeconomics, subsistence, seabirds and shorebirds, waterfowl, seals and sea lions, cetaceans, sea otters, and walruses. These presentations characterized the status of the resource, the current state of knowledge on the topic, and information needs related to an assessment of the effects of oil and gas development. An overview of each presentation and the presentation materials used at the meeting are provided in the Planning Meeting report. The reader should refer to that report as well as to the information presented in the current report for a more complete understanding of each resource.

\footnotetext{
${ }^{1}$ LaGory, K.E., J.R. Krummel, J.W. Hayse, I. Hlohowskyj, E.A. Stull, and L. Gorenflo. 2007. Proceedings of the North Aleutian Basin Information Status and Research Planning Meeting. OCS Study MMS 2007-031, U.S. Department of Interior, Minerals Management Service, Alaska Outer Continental Shelf Region, Anchorage, Alaska.
} 


\section{OCEANOGRAPHY AND ECOSYSTEMS}

This overview of information on oceanography and ecosystems of the North Aleutian Basin and southeastern Bering Sea is based on a collection of about 120 reports, research papers, and web-published materials dated from 1996 to 2006. Some literature on oceanography and ecosystems for areas outside the southeastern Bering Sea is included because the information is relevant to conditions in the North Aleutian Basin. Examples are the effects of the ice edge on oceanographic parameters, oceanographic effects of climate variability and regime shift, pollutants, and general circulation. A summary of model results related to circulation patterns, water mass distribution, and transport in the North Aleutian Basin was presented at the Planning Meeting by Wieslaw Maslowski of the Naval Postgraduate School. Application of this model to assessments of oil and gas development and information needed to improve the model were also provided.

Information on oceanography collected for the current report covers the following topics: physical oceanography (bathymetry, circulation, temperature, density, salinity, tides, and currents), chemical oceanography (nutrients and pollutants), benthos, biological oceanography (productivity, plankton, ecosystems and trophic structure), and coastal areas (shallow water, lagoons, estuaries, and islands). Table 1 summarizes the content of recent publications; full citations for these references are presented in Section 7.1.

In 1997, the bathymetry of the Bering Sea and Chukchi Sea was published by the U.S. Geological Survey (USGS), and in 2005 the USGS published a database on the coastal bathymetry that included the Bering Sea. Recent publications of circulation have included regional circulation of the Gulf of Alaska and Bering Sea, coastal currents near the Alaska Peninsula and Aleutian Islands, and more detailed studies of currents, turbulence, and fronts associated with Aleutian passes. Physical features studied include water transport, water origins, circulation (at the surface, intermediate depths, in deep waters, and over the Bering shelf), currents, gyres, fronts, tides, flow at the shelf edge, sea ice, and cold pools.

Climate and weather studies of the Bering Sea include the effects of solar radiation and temperature on sea ice and ocean circulation, and the formation of the cold pool. A sea ice atlas has been developed for Alaska and is periodically updated. Weather and climate have been evaluated in terms of biological oceanography and the organization of ecosystems. Historical data on sea surface temperatures have been studied for interannual changes in weather and climate. Modeling studies of water-column mixing have been interpreted in relation to nutrients and productivity.

Studies of physical oceanography of the Bering Sea have emphasized regional ocean circulation, primarily from data obtained in the summer. Evaluations of the potential effects of impacts from oil and gas exploration, development, and operations, as well as potential pollutant discharges, require circulation data on a relatively local scale and at all seasons of the year. More in-depth knowledge of the mechanisms of tidal effects in nearshore areas also is needed for an assessment of potential oil and gas development impacts in these nearshore areas. 
Distribution and transport of nutrients (e.g., nitrogen, phosphorus, and silica), carbon, and pollutants have been studied in relation to global climate, circulation, open water currents, currents in island passes, water column mixing, the ice edge, cold pools, circulation over the shelf, and planktonic productivity. Studies of organic and inorganic pollutants in the Bering Sea have included measurements of concentrations in seawater and biota, special distribution and transport, and pathways of distribution.

A large proportion of the shorebirds of the Western Hemisphere that breed in the Arctic use the coastal lagoons on the Aleutian Peninsula as staging areas during migration. Little information is available on the tides or currents into and out of these lagoons. These lagoons are close to areas of potential future development and should be studied.

The marine biology of the Bering Sea has been studied extensively in the last five years. Bacterial and viral production, turnover rate, and mortality rate have been measured. An experimental study investigated the ability of diatoms to alter the physical property of sea ice. The distribution of dinoflagellate cysts was interpreted with respect to sea surface temperature and sea ice. Phytoplankton studies have included measurements of primary productivity of the Bering Sea shelf edge, the time series of the spring bloom along the ice edge, and development of coccolithiphore populations responsible for altering water color.

Studies relating productivity to climate have identified isotopic evidence for declining primary productivity in the Bering Sea. Secondary productivity research has looked at the biomass of gelatinous zooplankton, data on composition and abundance of zooplankton and ichthyoplankton, the importance of episodic weather events, and the importance of water masses and circulation. Zooplankton in the Aleutian passes has been discussed in relation to the influence of the Alaska Stream and Alaska Coastal Current.

Ecological organization of the Bering Sea has received a great deal of attention, including the role of sea ice in organizing the ecosystem. Trophic pathways have been investigated using fatty acid signatures. However, the Bering Sea ecosystem has recently experienced changes in climate and changes resulting from unusual meteorological conditions. Biomass and diversity calculations from fishery trawl data have been used to evaluate regime shifts of the Bering Sea ecosystem. An oscillating-control hypothesis has been proposed to explain changes from bottomup control of ecosystem function in cold regimes to top-down control in warm regimes. This hypothesis has been explored with respect to planktonic and benthic production, marine mammals, and fish.

Various studies of the biological implication of regime shifts have been published. Regional atmospheric and hydrographic forcing is related to major changes in various components of the northern Bering Sea ecosystem. The effects of ecosystem change and regime status on fish population dynamics have been evaluated, emphasizing the walleye pollock (Theragra chalcogramma). Coordinated research efforts (e.g., the Bering Sea Ecosystem Study and the Bering-Aleutian Salmon International Survey) and workshops have been funded to study Bering Sea ecosystems, basin-shelf interactions, and regional changes associated with climate. 
Studies of Bering Sea benthic environments have examined carbon cycling, the importance of echinoderms in carbon remineralization, benthic community organization, productivity and community interactions, the effects of onshore disturbances on offshore benthic communities, and sediment oxygen demand in the St. Lawrence Island polynya. The role of the Bering Strait in benthic productivity and carbon cycling also has been evaluated.

There appear to be no recent studies of contaminants in the sediments or the benthos in the potential lease areas of the North Aleutian Basin. This information would be important in assessing and monitoring the impacts from oil and gas exploration, development, and operations. Benthic organisms of this area include important fishery species, as well as species consumed by marine birds and mammals.

Studies of the coastal areas of the Bering Sea have investigated the effects of tidal currents, fronts, and transport through Aleutian passes on zooplankton and seabirds. The impacts of sediment load from land disturbance on nearshore ice and benthic communities also have been assessed. No recent information was found on the biota of nearshore and intertidal areas of the north shore of the Alaska Peninsula. This information is needed because development of oil and gas production and transportation facilities could affect these areas, and because these areas would be the areas affected by any spill. 
TABLE 1. Publications from 1996 to 2006 Related to Oceanography and Ecosystems of the North Aleutian Basin.

\begin{tabular}{|c|c|c|c|c|}
\hline Authors & Date & Location & Topic & Document Content \\
\hline Abromaitis & 2000 & Bering Shelf & Primary productivity & $\begin{array}{l}\text { This thesis discusses the primary productivity of the Bering and } \\
\text { Chukchi Sea shelves using stable isotope ratios in seabirds. }\end{array}$ \\
\hline Alexander & 1999 & Bering Sea & Research programs & $\begin{array}{l}\text { This paper presents an overview of interdisciplinary studies of the } \\
\text { Bering Sea ecosystems up to about } 1997 \text {. }\end{array}$ \\
\hline AMAP & $1998 \mathrm{a}$ & Worldwide & Climate change & $\begin{array}{l}\text { This chapter presents an overview of climate change, UV-B } \\
\text { radiation, and its effect on the biosphere in high latitudes. }\end{array}$ \\
\hline AMAP & $1998 b$ & Worldwide & Pollutants & $\begin{array}{l}\text { This chapter discusses the pathways of pollutant distribution in } \\
\text { high-latitude environments. }\end{array}$ \\
\hline AMAP & $1998 \mathrm{c}$ & Worldwide & Physical & $\begin{array}{l}\text { This chapter gives a general description of the physical and } \\
\text { geographical characteristic of high latitudes. }\end{array}$ \\
\hline Ambrose et al. & 2001 & Chukchi Sea & Benthos, chemistry & $\begin{array}{l}\text { Observations of high densities and respiration rates of } \\
\text { echinoderms support the conclusion that echinoderms dominate } \\
\text { the benthic fauna of Arctic shelves and are important in carbon } \\
\text { remineralization. }\end{array}$ \\
\hline Arzhanova et al. & 1996 & Bering Sea & $\begin{array}{l}\text { Chemistry, primary } \\
\text { productivity }\end{array}$ & $\begin{array}{l}\text { This paper assesses relationships between seasonal variability of } \\
\text { nutrients and primary production in the Bering Sea. }\end{array}$ \\
\hline Bailey & 2000 & Bering Sea & $\begin{array}{l}\text { Regime shift, secondary } \\
\text { productivity }\end{array}$ & $\begin{array}{l}\text { Control of recruitment of walleye pollock appears to have shifted } \\
\text { in recent years from environmental effects on larvae to biological } \\
\text { control of juveniles. Ecosystem change and regime status need to } \\
\text { be considered when evaluating mechanisms underlying fish } \\
\text { population dynamics. }\end{array}$ \\
\hline BESIS Project Office & 1997 & Bering Sea & Climate, productivity & $\begin{array}{l}\text { This report considers the impacts of climate change on the Bering } \\
\text { Sea, including physical and biological parameters. }\end{array}$ \\
\hline $\begin{array}{l}\text { BEST Planning } \\
\text { Group }\end{array}$ & 2004 & Bering Sea & Research program & $\begin{array}{l}\text { This report discusses the development of a research plan for the } \\
\text { eastern Bering Sea Ecosystem. }\end{array}$ \\
\hline Bond and Overland & 2005 & Bering Sea & $\begin{array}{l}\text { Weather, circulation, } \\
\text { primary productivity, } \\
\text { secondary productivity }\end{array}$ & $\begin{array}{l}\text { This paper explores the importance of air-sea interactions } \\
\text { associated with episodic weather events to the transport of } \\
\text { nutrients into the Bering Sea region and associated primary and } \\
\text { secondary productivity. }\end{array}$ \\
\hline
\end{tabular}


Table 1 (Cont.)

\begin{tabular}{|c|c|c|c|c|}
\hline Authors & Date & Location & Topic & Document Content \\
\hline Brodeur et al. & 1999 & Bering Sea & Secondary productivity & $\begin{array}{l}\text { This paper reports a nearly } 10 \text {-fold increase in gelatinous } \\
\text { zooplankton in the Bering Sea from the 1970s to the 1990s and } \\
\text { evaluates hypotheses about the cause of the increases. }\end{array}$ \\
\hline Broerse et al. & 2003 & Bering Sea & Physical oceanography & $\begin{array}{l}\text { This paper reports the source of wintertime "bright waters" is } \\
\text { suspended particulate matter that reduces transparency. }\end{array}$ \\
\hline Budge et al. & 2002 & Bering Sea & Primary productivity, sea ice & $\begin{array}{l}\text { This presentation used fatty acid signatures to evaluate trophic } \\
\text { pathways of sea ice algae. }\end{array}$ \\
\hline Chen et al. & 2003 & Bering Sea & Carbon flux & $\begin{array}{l}\text { This paper used isotopic ratios to evaluate particulate organic } \\
\text { export fluxes. }\end{array}$ \\
\hline Cherniawsky et al. & 2005 & Bering Strait & Physical & $\begin{array}{l}\text { This paper reports the results of measuring Bering Strait transports } \\
\text { using satellite altimetry. }\end{array}$ \\
\hline Chernyak et al. & 1996 & $\begin{array}{l}\text { Bering Sea, } \\
\text { Chukchi Sea }\end{array}$ & Pollutants & $\begin{array}{l}\text { This paper reports observations of pesticides used in the 1990s in } \\
\text { air, ice, fog, seawater, and surface microlayer in the Bering and } \\
\text { Chukchi Seas. }\end{array}$ \\
\hline CIFAR & 2003 & General & Research program & $\begin{array}{l}\text { This report identifies studies funded in the second year (July-June } \\
\text { 2002/2003) of a cooperative agreement between the Cooperative } \\
\text { Institute for Arctic Research and the National Oceanographic and } \\
\text { Atmospheric Administration (NOAA). Results are summarized } \\
\text { and publications listed. }\end{array}$ \\
\hline CIFAR & 2004 & General & Research program & $\begin{array}{l}\text { This report identifies studies funded in the third year (July-June } \\
2003 / 2004 \text { ) of a cooperative agreement between the Cooperative } \\
\text { Institute for Arctic Research and NOAA. Results are summarized } \\
\text { and publications listed. }\end{array}$ \\
\hline CIFAR & 2005 & General & Research program & $\begin{array}{l}\text { This report identifies studies funded in the fourth year (July-June } \\
\text { 2004/2005) of a cooperative agreement between the Cooperative } \\
\text { Institute for Arctic Research and NOAA. Results are summarized } \\
\text { and publications listed. }\end{array}$ \\
\hline Cokelet and Stabeno & 1997 & Bering Sea & Physical & $\begin{array}{l}\text { This paper reports mooring observation of thermal structure, } \\
\text { density stratification, and currents in the southeastern Bering Sea } \\
\text { basin. }\end{array}$ \\
\hline
\end{tabular}


Table 1 (Cont.)

\begin{tabular}{|c|c|c|c|c|}
\hline Authors & Date & Location & Topic & Document Content \\
\hline Cokelet et al. & 1996 & Bering Sea & Physical & $\begin{array}{l}\text { Acoustic doppler current profiler measurements were used to } \\
\text { measure geotropic circulation in the Bering Sea basin. }\end{array}$ \\
\hline Connors et al. & 2002 & Bering Sea & $\begin{array}{l}\text { Benthos, regime shift, } \\
\text { ecosystem }\end{array}$ & $\begin{array}{l}\text { Data on Bering Sea bottom trawl surveys were interpreted in terms } \\
\text { of regime shift and ecosystem reorganization. }\end{array}$ \\
\hline Cooper et al. & 2002 & Bering Sea & $\begin{array}{l}\text { Primary productivity, } \\
\text { sediment carbon flux }\end{array}$ & $\begin{array}{l}\text { Data on chlorophyll a and sediment oxygen demand was used to } \\
\text { evaluate whether UV radiation affects productivity in the St. } \\
\text { Lawrence Island polynya, a region of high biological productivity. }\end{array}$ \\
\hline Coyle & 2005 & Aleutian Islands & Circulation, zooplankton & $\begin{array}{l}\text { Physical and biological (zooplankton) indicators were used to } \\
\text { identify the water masses prevalent in ocean passes in the eastern } \\
\text { and central Aleutian Islands. The central passes were characterized } \\
\text { as an oceanic environment influenced by Alaskan Stream water, } \\
\text { while the eastern passes were influenced by the Alaska Coastal } \\
\text { Current. }\end{array}$ \\
\hline Doyle et al. & 2002 & $\begin{array}{l}\text { Bering Sea, Gulf } \\
\text { of Alaska }\end{array}$ & Ichthyoplankton & $\begin{array}{l}\text { This paper examines data on ichthyoplankton assemblages in the } \\
\text { southern Bering Sea, the Gulf of Alaska, and off the U.S. west } \\
\text { coast. }\end{array}$ \\
\hline Duffy-Anderson et al. & 2006 & Bering Sea & Ichthyoplankton & $\begin{array}{l}\text { This paper analyzed spatial and temporal patterns of summer } \\
\text { ichthyoplankton assemblages on the eastern Bering Shelf and } \\
\text { interpreted them in relation to water masses and circulation. }\end{array}$ \\
\hline Gradinger and Bluhm & 2005 & Beaufort Sea & Disturbance & $\begin{array}{l}\text { This paper discusses the impact of sediment load on nearshore ice } \\
\text { and benthic communities. Implications for the impacts of on-land } \\
\text { disturbances on nearshore communities are discussed. }\end{array}$ \\
\hline Grebmeier & 1999 & $\begin{array}{l}\text { Bering Sea, } \\
\text { Chukchi Sea }\end{array}$ & $\begin{array}{l}\text { Ecosystems, benthic } \\
\text { productivity }\end{array}$ & $\begin{array}{l}\text { This paper discusses the role of the Bering Strait in benthic } \\
\text { productivity and carbon cycling. }\end{array}$ \\
\hline Grebmeier & 2006 & $\begin{array}{l}\text { Beaufort Sea, } \\
\text { Chukchi Sea }\end{array}$ & $\begin{array}{l}\text { Research programs, } \\
\text { ecosystems }\end{array}$ & $\begin{array}{l}\text { This website describes the Western Arctic Shelf-Basin } \\
\text { Interactions Project. This project investigates global climate } \\
\text { change and the physical, chemical, and biological interactions. }\end{array}$ \\
\hline $\begin{array}{l}\text { Grebmeier and } \\
\text { Dunton }\end{array}$ & 2000 & $\begin{array}{l}\text { Bering Sea, } \\
\text { Chukchi Sea }\end{array}$ & $\begin{array}{l}\text { Ecosystems, benthic } \\
\text { productivity }\end{array}$ & $\begin{array}{l}\text { This paper discusses the high productivity of the Beaufort and } \\
\text { Chukchi Seas and discusses benthic productivity and community } \\
\text { interactions. }\end{array}$ \\
\hline
\end{tabular}


Table 1 (Cont.)

\begin{tabular}{|c|c|c|c|c|}
\hline Authors & Date & Location & Topic & Document Content \\
\hline Grebmeier et al. & 2006 & Bering Sea & Productivity, regime shift & $\begin{array}{l}\text { This paper shows that northern Bering Sea ecosystems are shifting } \\
\text { away from the characteristics of extensive seasonal sea-ice cover, } \\
\text { high water column and sediment carbon production, and tight } \\
\text { pelagic-benthic coupling of organic production. These changes are } \\
\text { contemporaneous with changes in regional atmospheric and } \\
\text { hydrographic forcing. Geographic displacement of marine } \\
\text { mammal population distributions has coincided with a reduction in } \\
\text { benthic prey populations, an increase in pelagic fish, a reduction in } \\
\text { sea ice, and an increase in air and ocean temperatures. }\end{array}$ \\
\hline Hare and Mantua & 2002 & $\begin{array}{l}\text { North Pacific, } \\
\text { Bering Sea }\end{array}$ & $\begin{array}{l}\text { Regime shift, physical, } \\
\text { biological, ecosystem }\end{array}$ & $\begin{array}{l}\text { This report evaluated } 100 \text { physical and biological time series to } \\
\text { identify regime shifts in North Pacific and Bering Sea ecosystems } \\
\text { using atmospheric, terrestrial, oceanic, and ecosystem factors. }\end{array}$ \\
\hline Herman et al. & 2002 & Bering Sea & Physical & $\begin{array}{l}\text { This paper describes an eddy-resolving circulation model that } \\
\text { includes both tidal and subtidal dynamics for the southeast Bering } \\
\text { Sea. Modeling results suggest that the pattern of vertical mixing in } \\
\text { this area is strongly affected by both tidal and subtidal currents. }\end{array}$ \\
\hline Hoff & 2006 & Bering Sea & Biological, regime shift & $\begin{array}{l}\text { Fishery trawl data were used to evaluate regime shift in the eastern } \\
\text { Bering Sea, using biomass data for diversity calculations. }\end{array}$ \\
\hline Hunt et al. & 2002 & Bering Sea & $\begin{array}{l}\text { Physical, biological, regime } \\
\text { shift }\end{array}$ & $\begin{array}{l}\text { This paper proposes the Oscillating Control Hypothesis, which } \\
\text { predicts that pelagic ecosystem function in the southeastern Bering } \\
\text { Sea will alternate between primarily bottom-up control in cold } \\
\text { regimes and primarily top-down control in warm regimes, and } \\
\text { discusses this hypothesis with regard to climate and physical } \\
\text { oceanography, planktonic and benthic production, and marine } \\
\text { mammal and fish populations. }\end{array}$ \\
\hline Hunt and Stabeno & 2002 & Bering Sea & $\begin{array}{l}\text { Physical, biological, } \\
\text { ecosystem }\end{array}$ & $\begin{array}{l}\text { This paper explores the relationships between climate change and } \\
\text { ecosystems of the southeast Bering Sea. }\end{array}$ \\
\hline Hunt and Stabeno & 2005 & Aleutian Islands & Physical, biological & $\begin{array}{l}\text { This paper discusses the differences in oceanography east and west } \\
\text { of Samalga Pass. The authors conclude that there are at least two } \\
\text { ecological regions, and that there is high variability on both long } \\
\text { and short time scales. }\end{array}$ \\
\hline
\end{tabular}


Table 1 (Cont.)

\begin{tabular}{|c|c|c|c|c|}
\hline Authors & Date & Location & Topic & Document Content \\
\hline Huntington & 2000 & $\begin{array}{l}\text { Bering Sea, } \\
\text { Chukchi Sea }\end{array}$ & Climate, physical, biological & $\begin{array}{l}\text { This report is a compendium of papers discussing the impacts of } \\
\text { changes in climate and sea ice in the Bering Sea and Chukchi Sea } \\
\text { on the marine environment presented at the February } 2000 \text { Marine } \\
\text { Mammal Commission workshop on changes in sea ice. }\end{array}$ \\
\hline $\begin{array}{l}\text { Interagency Arctic } \\
\text { Research Policy } \\
\text { Committee }\end{array}$ & 2005 & General & Research programs & $\begin{array}{l}\text { This website maintained by the National Science Foundation, } \\
\text { Office of Polar Programs, provides links to past issues of the } \\
\text { publication Arctic Research of the United States. }\end{array}$ \\
\hline Jin et al. & 2006 & Bering Sea & $\begin{array}{l}\text { Modeling, primary } \\
\text { production }\end{array}$ & $\begin{array}{l}\text { A vertically one-dimensional ecosystem model was developed and } \\
\text { applied to the southeastern Bering Sea middle shelf. The } \\
\text { simulation studies showed the effects of tidal mixing, wind } \\
\text { stirring, and thermal stratification on the timing and magnitude of } \\
\text { the phytoplankton bloom and gross and net primary production. }\end{array}$ \\
\hline Johnson et al. & 2004 & $\begin{array}{l}\text { Bering Sea, } \\
\text { Aleutian Basin }\end{array}$ & Physical & $\begin{array}{l}\text { Mean circulation and water properties within the Aleutian Basin of } \\
\text { the Bering Sea were investigated using hydrographic and } \\
\text { subsurface pressure displacement data from a regional array of } 14 \\
\text { profiling conductivity-temperature-depth floats. The data revealed } \\
\text { the deep signature of the Bering Slope Current, Aleutian North } \\
\text { Slope Current, and the Bering Slope Current. Transport estimates } \\
\text { were derived from the data. }\end{array}$ \\
\hline Kachel et al. & 2002 & Bering Sea & $\begin{array}{l}\text { Modeling, physical, primary } \\
\text { production }\end{array}$ & $\begin{array}{l}\text { This paper describes the use of a model based on surface heat flux } \\
\text { and water-column mixing to explain the existence of cold belts } \\
\text { associated with fronts. Tidal and wind mixing in the presence of a } \\
\text { nutrient reservoir pump nutrients into the photic zone and prolong } \\
\text { primary production. }\end{array}$ \\
\hline Kaltin and Anderson & 2005 & $\begin{array}{l}\text { Bering Sea, } \\
\text { Chukchi Sea }\end{array}$ & Physical, chemical & $\begin{array}{l}\text { This paper presents an evaluation of the relative importance of } \\
\text { processes that influence the transport of carbon dioxide in water } \\
\text { transported over the Bering-Chukchi Sea shelf. }\end{array}$ \\
\hline Khen & 2005 & Bering Sea & Physical & $\begin{array}{l}\text { This paper analyzes the temperature, salinity, and pycnoclines of } \\
\text { the Bering Sea during } 2002-2003 \text {. }\end{array}$ \\
\hline
\end{tabular}


Table 1 (Cont.)

\begin{tabular}{|c|c|c|c|c|}
\hline Authors & Date & Location & Topic & Document Content \\
\hline King & 2005 & Bering Sea & $\begin{array}{l}\text { Regime shift, physical, } \\
\text { biological, ecological }\end{array}$ & $\begin{array}{l}\text { This report provides an overview of fisheries and ecosystem } \\
\text { responses to recent regime shifts in the North Pacific. It includes a } \\
\text { detailed chapter on recent changes in temperature and physical, } \\
\text { biological, and ecosystem components of the southeastern Bering } \\
\text { Sea. }\end{array}$ \\
\hline Kowalik & 1999 & Bering Sea & Physical & This paper describes tides and tidal currents in the Bering Sea. \\
\hline Krembs et al. & 2002 & General & Chemical, biological & $\begin{array}{l}\text { This poster session describes outdoor experiments on the ability of } \\
\text { a diatom to alter the physical properties of sea ice. }\end{array}$ \\
\hline Ladd et al. & $2005 a$ & Aleutian Islands & Physical, chemical & $\begin{array}{l}\text { Water properties (salinity, temperature, and nitrate) were measured } \\
\text { through Aleutian Island passes. These data were interpreted with } \\
\text { respect to water movement, origin, and nutrient transport. Samalga } \\
\text { Pass was identified as the transition between the eastern and } \\
\text { central Aleutian Islands }\end{array}$ \\
\hline Ladd et al. & $2005 b$ & Aleutian Islands & Physical, biological & $\begin{array}{l}\text { This paper discusses the relationship between hydrographic } \\
\text { features of Aleutian passes and observations of seabird foraging. }\end{array}$ \\
\hline Livingston et al. & 1997 & Bering Sea & Research programs & $\begin{array}{l}\text { This report contains papers on the Bering Sea ecosystem, } \\
\text { including past and ongoing research, inventory of data and } \\
\text { information bases, and data gaps and future research needs. }\end{array}$ \\
\hline Loughlin and Ohtani & 1999 & Bering Sea & $\begin{array}{l}\text { Physical, chemical, } \\
\text { biological }\end{array}$ & $\begin{array}{l}\text { This compendium of papers on the Bering Sea ecosystem includes } \\
\text { reports by many of the important Bering Sea researchers on the } \\
\text { physical, chemical, and biological components of the ecosystem. }\end{array}$ \\
\hline Lovvren et al. & 2005 & Bering Sea & Chemical & $\begin{array}{l}\text { This paper discusses transport of organic matter under sea ice in } \\
\text { the north-central Bering Sea. }\end{array}$ \\
\hline Luchin et al. & 1999 & Bering Sea & Physical & $\begin{array}{l}\text { Vertical structure, temporal variability, and features of temporal } \\
\text { and spatial structure were analyzed from data on temperature and } \\
\text { salinity. }\end{array}$ \\
\hline Luchin et al. & 2002 & Bering Sea & Physical, regime shifts & $\begin{array}{l}\text { This paper discusses long-term and large-scale patterns of } \\
\text { atmosphere-ice-sea relationships. }\end{array}$ \\
\hline MacDonald et al. & 2003 & General & Climate change, pollutants & $\begin{array}{l}\text { This paper discusses potential relationships between global climate } \\
\text { change and long-range transport of persistent organic pollutants. }\end{array}$ \\
\hline
\end{tabular}


Table 1 (Cont.)

\begin{tabular}{|c|c|c|c|c|}
\hline Authors & Date & Location & Topic & Document Content \\
\hline Macklin & 1999 & Bering Sea & $\begin{array}{l}\text { Physical, chemical, } \\
\text { biological }\end{array}$ & $\begin{array}{l}\text { This report presents a multi-author review of the conditions } \\
\text { occurring in the Bering Sea during the anomalous conditions of the } \\
\text { summers of } 1997 \text { and } 1998 \text {. The report includes physical, } \\
\text { chemical, and biological parameters. }\end{array}$ \\
\hline Merico et al. & 2003 & Bering Sea & Phytoplankton & $\begin{array}{l}\text { Satellite imagery was used to survey for blooms of the } \\
\text { coccolithophorid Emeliania huxleyi in the Bering Sea. No } \\
\text { evidence was found for blooms of this alga from } 1978 \text { to } 1995 . \\
\text { Imagery of the blooms of } 1996 \text { and } 1997 \text { were analyzed. }\end{array}$ \\
\hline Minobe & 2002 & Bering Sea & Physical & $\begin{array}{l}\text { This paper discusses interannual and interdecadal changes in the } \\
\text { Bering Sea. }\end{array}$ \\
\hline Mizobata and Saitoh & 2003 & Bering Sea & Physical & $\begin{array}{l}\text { This research used remote sensing to describe cyclonic and } \\
\text { anticyclonic eddies in the southeastern Bering Sea during 1998- } \\
1999 .\end{array}$ \\
\hline Mizobata and Saitoh & 2004 & Bering Sea & $\begin{array}{l}\text { Physical, primary } \\
\text { production }\end{array}$ & $\begin{array}{l}\text { This research used remote sensing to assess variability of eddies } \\
\text { and primary productivity along the Bering Sea shelf edge during } \\
1998-2000 \text {. }\end{array}$ \\
\hline Mordy et al. & 2005 & Aleutian Islands & $\begin{array}{l}\text { Physical, chemical, primary } \\
\text { production }\end{array}$ & $\begin{array}{l}\text { This paper presents detailed data on salinity, water flow, nutrients } \\
\text { (nitrate, phosphate, silicic acid) and primary production along the } \\
\text { eastern Aleutian Islands and island passes. }\end{array}$ \\
\hline Napp et al. & 2000 & Bering Sea & Physical, biological & $\begin{array}{l}\text { This paper examines the differences in the physical processes of } \\
\text { oceanic and shelf waters in the eastern Bering Sea. The report } \\
\text { concludes that in the oceanic region, interannual variation in food } \\
\text { for first-feeding pollock larvae is determined by advection; in the } \\
\text { shelf region, it is the coupled dynamics of the atmosphere-ice- } \\
\text { ocean system. }\end{array}$ \\
\hline Napp and Hunt & 2001 & Bering Sea & Climate, physical, biological & $\begin{array}{l}\text { This paper discusses the linkages among climate, weather, ocean } \\
\text { and biology in the southeastern Bering Sea. }\end{array}$ \\
\hline Niebauer & 1998 & Bering Sea & Physical, regime shift & $\begin{array}{l}\text { This paper examines the variability in Bering Sea ice cover as } \\
\text { affected by a regime shift in the North Pacific in the period of } \\
\text { 1947-1999. }\end{array}$ \\
\hline Niebauer et al. & 1996 & Bering Sea & Biology & $\begin{array}{l}\text { This paper presents time series of the spring bloom for the Bering } \\
\text { Sea ice edge. }\end{array}$ \\
\hline
\end{tabular}


Table 1 (Cont.)

\begin{tabular}{|c|c|c|c|c|}
\hline Authors & Date & Location & Topic & Document Content \\
\hline Niebauer et al. & 1999 & Bering Sea & Physical & $\begin{array}{l}\text { This paper examines the interactions between ocean, ice, and } \\
\text { atmosphere that characterize the Bering Sea. }\end{array}$ \\
\hline NOAA & 2006 & Bering Sea & Climate, ecosystems & $\begin{array}{l}\text { This web page provides links to Arctic information, including the } \\
\text { Bering Sea Climate and Ecosystems website. }\end{array}$ \\
\hline Okkonen & 2001 & Bering Sea & Physical & $\begin{array}{l}\text { This paper discusses the results of current measurements across the } \\
\text { Aleutian Basin to the Bering Slope. }\end{array}$ \\
\hline Okkonen et al. & 2004 & Bering Sea & Productivity & $\begin{array}{l}\text { This paper reports on the use of satellite and hydrographic } \\
\text { observations of chlorophyll a concentrations, salinity, and } \\
\text { fluorescence to describe the surface structure of the "Green Belt" } \\
\text { and its relationship to the Bering Slope Current. The results } \\
\text { suggest that eddies are important in causing the variability in } \\
\text { chlorophyll distribution during the spring bloom in the central } \\
\text { Bering Sea. }\end{array}$ \\
\hline Overland and Stabeno & 2004 & Bering Sea & Physics, ecosystems & $\begin{array}{l}\text { This paper discusses the shift in temperatures of the Bering Sea } \\
\text { and the effects on the ecosystem. }\end{array}$ \\
\hline Overland et al. & 2002 & Arctic & Physical & $\begin{array}{l}\text { This report discusses what is known and not known about large- } \\
\text { scale atmosphere-cryosphere interactions. It discusses the most } \\
\text { pressing scientific questions to be resolved. }\end{array}$ \\
\hline Radi et al. & 2001 & $\begin{array}{l}\text { Bering Sea, } \\
\text { Chukchi Sea }\end{array}$ & Biological & $\begin{array}{l}\text { Surface sediment samples from the Bering and Chukchi Seas were } \\
\text { examined for dinoflagellate cysts. Distributions of taxa were } \\
\text { interpreted with respect to latitude and hydrographic conditions, } \\
\text { including sea ice and sea surface temperature. }\end{array}$ \\
\hline Reed & 1998 & Bering Sea & Physical & This paper describes flow over the southeastern Bering Sea shelf. \\
\hline Reed and Stabeno & 1996 & Bering Sea & Physical & $\begin{array}{l}\text { This paper describes the climatological mean summer circulation } \\
\text { over the eastern Bering Sea shelf. }\end{array}$ \\
\hline Reed and Stabeno & 1997 & Aleutian Islands & Physical & This paper describes flow along the Aleutian chain. \\
\hline Reed and Stabeno & 1999 & $\begin{array}{l}\text { Bering Sea, } \\
\text { Aleutian Islands }\end{array}$ & Physical & $\begin{array}{l}\text { This paper describes flow through the Aleutian passes into the } \\
\text { Bering Sea and eastward currents along the Aleutian Island chain. }\end{array}$ \\
\hline Robertson & 1997 & $\begin{array}{l}\text { Bering Sea, } \\
\text { Chukchi Sea }\end{array}$ & Bathymetry & $\begin{array}{l}\text { This paper describes bathymetry coverages for the Bering and } \\
\text { Chukchi Seas developed by the USGS. }\end{array}$ \\
\hline Rodionov et al. & $2005 \mathrm{a}$ & Bering Sea & Climate & $\begin{array}{l}\text { This paper discusses the Aleutian low and winter climatic } \\
\text { conditions in the Bering Sea. }\end{array}$ \\
\hline
\end{tabular}


Table 1 (Cont.)

\begin{tabular}{|c|c|c|c|c|}
\hline Authors & Date & Location & Topic & Document Content \\
\hline Rodionov et al. & $2005 b$ & Aleutian Islands & Climate & $\begin{array}{l}\text { This paper discusses the spatial and temporal variability of climate } \\
\text { along the Aleutian chain. }\end{array}$ \\
\hline Rodionov et al. & $2005 c$ & Bering Sea & Physical & $\begin{array}{l}\text { This paper presents historical and recent data on sea surface } \\
\text { temperatures of a location near the Pribilof Islands in the Bering } \\
\text { Sea. }\end{array}$ \\
\hline Schell & 1998 & Bering Sea & Biological & $\begin{array}{l}\text { This paper presents isotopic evidence for declining primary } \\
\text { productivity in the Bering Sea. }\end{array}$ \\
\hline Schell & 2000 & Bering Sea & Biological & $\begin{array}{l}\text { This paper reports the use of isotope ratios in whale baleen to } \\
\text { assess productivity in the Bering Sea. }\end{array}$ \\
\hline $\begin{array}{l}\text { Schumacher and } \\
\text { Stabeno }\end{array}$ & 1998 & Bering Sea & Physical, biological & $\begin{array}{l}\text { This paper discusses characteristics of the continental shelf of the } \\
\text { Bering Sea. }\end{array}$ \\
\hline Schumacher et al. & 2003 & Bering Sea & Climate, biological & $\begin{array}{l}\text { Discusses climate change in the southeastern Bering Sea and its } \\
\text { biological consequences. }\end{array}$ \\
\hline Smith and Lee & 2005 & Alaska & Physical & $\begin{array}{l}\text { Abstract describing the development of a GIS-based Alaska Sea } \\
\text { Ice Atlas by the University of Alaska. }\end{array}$ \\
\hline Springer et al. & 1996 & Bering Sea & Biological & $\begin{array}{l}\text { This paper discusses primary productivity (the "green belt") at the } \\
\text { Bering Sea shelf edge. }\end{array}$ \\
\hline Stabeno and Overland & 2001 & Bering Sea & Physical & $\begin{array}{l}\text { This paper discusses observations of earlier transitions from winter } \\
\text { to spring in the Bering Sea. }\end{array}$ \\
\hline Stabeno et al. & 1998 & Bering Sea & Physical & $\begin{array}{l}\text { This paper contains under-ice observations of water column } \\
\text { temperature, salinity, and spring phytoplankton dynamics on the } \\
\text { eastern Bering Sea shelf }\end{array}$ \\
\hline Stabeno et al. & 1999 & Bering Sea & Physical & $\begin{array}{l}\text { This chapter discusses the physical oceanography of the Bering } \\
\text { Sea, including general circulation, circulation in passes, circulation } \\
\text { in the upper ocean, interior flow, eddies, deep circulation, shelf- } \\
\text { slope exchange, shelf flow, and tidal currents. }\end{array}$ \\
\hline Stabeno et al. & 2001 & Bering Sea & Physical & $\begin{array}{l}\text { This paper discusses the various implications of the temporal } \\
\text { variability of the physical environment on the southeastern Bering } \\
\text { Sea. }\end{array}$ \\
\hline
\end{tabular}


Table 1 (Cont.)

\begin{tabular}{|c|c|c|c|c|}
\hline Authors & Date & Location & Topic & Document Content \\
\hline Stabeno et al. & $2002 a$ & Bering Sea & Physical, chemical & $\begin{array}{l}\text { This paper investigates variability of physical and chemical } \\
\text { characteristics along the } 70 \text {-meter isobath of the southeastern } \\
\text { Bering Sea. Defines the southeastern cold pool, an intermediate } \\
\text { zone, and the northern cold pool. }\end{array}$ \\
\hline Stabeno et al. & $2002 b$ & Bering Sea & Physical & $\begin{array}{l}\text { This paper reports investigations of inflow through Unimak Pass. } \\
\text { Discusses the seasonal effects of freshwater discharge, tidal } \\
\text { mixing, and alongshore winds. Discusses implications of inflow } \\
\text { with nutrient transport. }\end{array}$ \\
\hline Stabeno et al. & $2005 a$ & Bering Sea & Physical & $\begin{array}{l}\text { This paper is an introduction to processes that control variability in } \\
\text { productivity and ecosystem structure of the Aleutian Archipelago. }\end{array}$ \\
\hline Stabeno et al. & $2005 b$ & Bering Sea & Physical & $\begin{array}{l}\text { This paper examines temperature, salinity, and transport in } \\
\text { Aleutian passes. }\end{array}$ \\
\hline Stabeno et al. & 2006 & Bering Sea & Physical & $\begin{array}{l}\text { This report discusses long-term changes in temperature and ice } \\
\text { cover of the Bering Sea shelf. }\end{array}$ \\
\hline Steward et al. & 1996 & $\begin{array}{l}\text { Bering Sea, } \\
\text { Chukchi Sea }\end{array}$ & Biological & $\begin{array}{l}\text { This paper reports measurements of viral and bacterial production, } \\
\text { turnover rate, and mortality rate in seawater of the Bering and } \\
\text { Chukchi Seas. }\end{array}$ \\
\hline Strachan et al. & 2001 & $\begin{array}{l}\text { Bering Sea, } \\
\text { Chukchi Sea }\end{array}$ & Pollutants & $\begin{array}{l}\text { This paper presents measurements of organochlorine compounds } \\
\text { in the Chukchi and Bering Seas, with an emphasis on PCBs and } \\
\text { DDT. }\end{array}$ \\
\hline Tynan & 1999 & Bering Sea & Physical, biological & $\begin{array}{l}\text { This paper discusses the effects of the } 1997 \text { El Niño on the pelagic } \\
\text { ecosystem of the Bering Sea. This paper links shifts in whale } \\
\text { distributions to shifts in plankton associated with either the El } \\
\text { Niño or longer term changes. }\end{array}$ \\
\hline University of Alaska & 2001 & Alaska & Physical & $\begin{array}{l}\text { This web page provides a link to the Alaska Sea Ice Atlas and } \\
\text { related publications. }\end{array}$ \\
\hline USGS & 2007 & $\begin{array}{l}\text { Bering Sea, } \\
\text { Chukchi Sea, } \\
\text { Beaufort Sea }\end{array}$ & Bathymetry & $\begin{array}{l}\text { This web page provides links to the USGS database on the coastal } \\
\text { bathymetry of the Bering, Chukchi, and Beaufort Seas. }\end{array}$ \\
\hline $\begin{array}{l}\text { van Meurs and } \\
\text { Stabeno }\end{array}$ & 1999 & Bering Sea & Physical, chemical & $\begin{array}{l}\text { Satellite-tracked drifters showed an episodic event of onshore flow } \\
\text { in the southeastern Bering Sea. Such flow can be a mechanism for } \\
\text { replenishment of nutrients on the shelf. }\end{array}$ \\
\hline
\end{tabular}


Table 1 (Cont.)

\begin{tabular}{|c|c|c|c|c|}
\hline Authors & Date & Location & Topic & Document Content \\
\hline Vance et al. & 1998 & Bering Sea & Biological & $\begin{array}{l}\text { This paper reports aquamarine waters in the eastern Bering Sea. } \\
\text { This color anomaly was ascribed to coccolithophorids, such as } \\
\text { Emiliania huxley. }\end{array}$ \\
\hline Vlietstra et al. & 2005 & $\begin{array}{l}\text { Aleutian Islands, } \\
\text { Bering Sea }\end{array}$ & Physical, biological & $\begin{array}{l}\text { This paper discusses the relationships between tidal fronts, } \\
\text { zooplankton size, and the size of prey used by the short-tailed } \\
\text { shearwater. }\end{array}$ \\
\hline Wang & 1999 & $\begin{array}{l}\text { Kuskokwim } \\
\text { River }\end{array}$ & Pollutants & $\begin{array}{l}\text { This report contains investigations of the spatial distribution of } \\
\text { mercury and other chemicals in the Kuskokwim River. Transport } \\
\text { of chemicals in water and sediments is also addressed. }\end{array}$ \\
\hline Weller et al. & 1998 & $\begin{array}{l}\text { Alaska, Bering } \\
\text { Sea }\end{array}$ & Climate impacts & Regional workshop report on climate change impacts. \\
\hline Wells et al. & 1997 & $\begin{array}{l}\text { Bering Sea, } \\
\text { Arctic Ocean }\end{array}$ & Chemical & $\begin{array}{l}\text { This paper discusses transport of organic matter between the } \\
\text { Bering Sea and Arctic Ocean and the effect on } \mathrm{CO}_{2} \text { distributions. }\end{array}$ \\
\hline Williams & 1999 & Alaska & Physical, biological & $\begin{array}{l}\text { This thesis discusses the interrelationships between Pacific herring } \\
\text { and physical variables. }\end{array}$ \\
\hline Wirts and Johnson & 2005 & $\begin{array}{l}\text { Aleutian Basin, } \\
\text { Bering Sea }\end{array}$ & Physical & $\begin{array}{l}\text { This paper discusses the implications of temperature-density-depth } \\
\text { measurements on circulation of the southeastern Aleutian Basin } \\
\text { during 2002-2003. }\end{array}$ \\
\hline $\begin{array}{l}\text { Woodgate and } \\
\text { Aagaard }\end{array}$ & 2004 & Bering Strait & Physical & $\begin{array}{l}\text { This paper reports measurements of freshwater flow through the } \\
\text { Bering Strait. }\end{array}$ \\
\hline Woodgate et al. & 2005 & Bering Strait & Physical & $\begin{array}{l}\text { This paper reports measurements of freshwater flow through the } \\
\text { Bering Strait. }\end{array}$ \\
\hline $\begin{array}{l}\text { Wyllie-Escheverria } \\
\text { and Wooster }\end{array}$ & 1998 & Bering Sea & Biological & $\begin{array}{l}\text { This paper discusses the relationship between ice cover, the cold } \\
\text { pool, and fish distributions. }\end{array}$ \\
\hline $\begin{array}{l}\text { Wyllie-Escheverria } \\
\text { and Ohtani }\end{array}$ & 1999 & Bering Sea & Biological & $\begin{array}{l}\text { This chapter discusses the role of sea ice in organizing the Bering } \\
\text { Sea ecosystem. }\end{array}$ \\
\hline Yao et al. & 2002 & $\begin{array}{l}\text { Bering Sea, } \\
\text { Chukchi Sea }\end{array}$ & Pollutants & $\begin{array}{l}\text { This paper reports measurements of organochlorine pesticides in } \\
\text { seawater of the Bering and Chukchi Seas. }\end{array}$ \\
\hline
\end{tabular}




\section{FISH AND FISHERIES}

This overview of information on fish and fisheries of the North Aleutian Basin and southeastern Bering Sea is based on a collection of about 150 reports, research papers, and webpublished materials dated from 1996 to 2006. Some literature on life history, impacts of human activity, and ecology for locales outside of the southeastern Bering Sea (such as the Gulf of Alaska) is included when the literature adds to the knowledge base for species occurring near the North Aleutian Basin.

Presentations at the Planning Meeting included overviews of (1) federal fisheries by Diana Evans of the North Pacific Fishery Management Council, (2) commercial fisheries by Gunnar Knapp of the University of Alaska Anchorage, and (3) marine fish abundance and distribution by Michael Sigler of the National Marine Fisheries Service (NMFS). The presentations, which can be found in the Planning Meeting report, summarize available information and information needs on these topics relevant to an impact assessment of oil and gas development in the Basin.

Information on fish and fisheries collected for this report includes general descriptions of distribution and habitat; population size, population parameters, and population dynamics; biotic relationships, including disease and parasitism and trophic and ecosystem relationships; impacts of human activities (such as offshore placer mining) and impacts of commercial fisheries on other groups of marine animals such as noncommercial fishes; fishing activity and catch; and regulatory status, management, and conservation. Table 2 presents brief summaries of the content of recent publications; full citations are provided in Section 7.2.

Since 1996, publications have included descriptions of meetings and research programs, literature databases or bibliographies on fish species or groups, and general species descriptions. Research on walleye pollock and shellfish have perhaps received the most attention. Specific studies of life history or general biology have been published for a variety of fishes, including arctic cod (Arctogadus glacialis), walleye pollock, and threaded sculpins (Gymnocanthus pistilliger), as well as for a variety of shellfish (such as crabs and molluscs).

Recent publications evaluating the distributions of some species in the Bering Sea and Bristol Bay have been prepared annually for fishery forecasting, fishery trends, and habitat management. The relationship between fish distribution and physical oceanographic factors, including sea ice and regime shifts, has also been studied. The Alaska Department of Fish and Game (ADFG) and the Alaska Department of Natural Resources (ADNR) have produced detailed maps and lists of streams used as spawning habitat by anadromous fish and of Pacific herring (Clupea pallasii). Distributions of shellfish, such as king crab (Paralithodes camtschaticus), snow crab (Chionoecetes oplio), and weathervane scallop (Patinopectea caurinus) have been studied to support fishery management. In order to understand population fluctuations in many fish species, spatial and temporal patterns of larval and early juvenile fish have been studied. The distribution of fishes and the identification of sensitive habitat are also important information for oil spill response planning for Bristol Bay (ARRT 2001). 
Fish population size, population variability, recruitment, and escapement are regularly monitored in the southeastern Bering Sea and the streams of the Alaska Peninsula and Bristol Bay. Recent publications for salmon have addressed short- and long-term trends in populations, escapement goals, escapement surveys, population variation and structure, and genetic relationship between populations. Studies of various crab populations include population surveys, tagging studies, the relationship of populations to physical factors and predation by groundfish, growth rates, studies of the effects of sex discrimination in catch, and bycatch of females and juveniles. Recent publications for Pacific herring include estimates of stocks and studies of the relationship of herring populations to environmental and oceanographic variables. Recent studies of walleye pollock have examined genetics, egg hatching and egg cannibalism, population distribution and characteristics, and the abundance of larval and juvenile fish. Studies of groundfish include trawl surveys and population structure of Pacific populations of halibut (Hippoglossus stenolepis) using parasites as population markers.

Fish survey data can provide a detailed view of the distribution and abundance of important fishery species in the North Aleutian Basin. However, no recent information was found for many nearshore species, including those inhabiting the lagoons of the Alaska Peninsula. In addition, many fishery studies did not provide a year-round view of the distribution of commercially important species, but rather focused primarily on distribution and abundenace during the harvest season. Because impacts of oil and gas development must be assessed for four seasons, more data on abundance and distribution for all four seasons are needed.

Recent studies on the ecology of fishes in the Bering Sea have discussed the general ecology of a few selected species, the potential effects of climate variability or regime shifts on species, the dynamics of ecosystems at the ice edge, predation and parasitism, and factors affecting recruitment and population dynamics. Larval fish and juvenile fish are an important part of the food base of birds, fish, and mammals, and information on ichthyoplankton distribution and abundance is needed for the North Aleutian Basin. Assessments of the impacts of oil and gas development on ecological relationships in the North Aleutian Basin have not been conducted.

Relatively few studies have investigated the impacts of environmental factors on fisheries and/or the impact of fisheries activities on other species. Consequently, there is a relatively poor understanding of the role that fisheries have on human activities and natural ecosystem of the Bering Sea. Incidental catch by fisheries has been studied with respect to population dynamics, conservation, and regulation of other fish species, seabirds, and marine mammals. The effects of offshore placer mining on crabs, effects of seismic air guns on the behavior of snow crabs, interactions between the gillnet fishery and oil and gas activities, and the effects of oil spills on various species have been studied. Heavy metal and organic contamination have been measured in crabs in the Norton Sound and in freshwater fish. Although there has been considerable work done on the effects of the Exxon Valdez oil spill, relatively little recent information was found on the interaction between fisheries and oil and gas development. Further study of the impacts of exploration, development, and production on fishery resources of the North Aleutian Basin is needed. 
In general, there are many recent fishery publications for the North Aleutian Basin. Commercial and subsistence fisheries for salmon, groundfish, crab species, and other shellfish are monitored each season. Population estimates are used to evaluate harvest strategies and predict catch. Historical records of catch are evaluated to identify trends in population and catch parameters (such as abundance and harvest levels). Some studies have examined the potential role of climate and oceanographic conditions on trends in population and catch parameters. Catch statistics are gathered to estimate subsistence use and economics of the fishery and to set management policies and regulations. The economies of fishing communities also have been profiled.

Many of the recent studies of fish and fisheries are related to regulations and management plans. Regulations have been promulgated to identify fishery seasons, licensing, catch limits, and other restrictions and requirements, and in an effort to minimize or control bycatch of other fish, seabirds, and marine mammals. Alternative harvest strategies, ecosystems, and sustainability have been studied to facilitate the evaluation and establishment of management practices. Although fisheries have been well-studied in the southeastern Bering Sea, one subject that has not been addressed in depth is the effect of oil and gas activities on the regulation of fishing activities. 
TABLE 2. Publications from 1996 to 2006 Related to Fish and Fisheries of the North Aleutian Basin.

\begin{tabular}{|c|c|c|c|c|c|}
\hline Authors & Date & Location & Topic & Species & Document Content \\
\hline ADFG & 1997 & Bristol Bay & Management & General & Bristol Bay commercial fisheries annual report for 1996. \\
\hline ADFG & 1997 & Western Alaska & Management & Shellfish & Western Region shellfish fisheries annual management report. \\
\hline ADFG & 2004 & Aleutian Islands & $\begin{array}{l}\text { Management, } \\
\text { impact }\end{array}$ & General & $\begin{array}{l}\text { ADFG news release about fishery closures after the Selendang } \\
\text { Ayu oil spill. }\end{array}$ \\
\hline ADFG & 2005 & Aleutian Islands & Management & General & $\begin{array}{l}\text { An announcement of reopening of the Makushin/Skan Bay area } \\
\text { to commercial fishing. This area was previously closed to all } \\
\text { commercial fishing activity due to the Selendang Ayu oil spill. }\end{array}$ \\
\hline $\mathrm{ADFG}$ & $2006 \mathrm{a}$ & Bristol Bay & Management & Salmon & Map showing the location of the Bristol Bay salmon districts. \\
\hline ADFG & $2006 b$ & Alaska & Management & Salmon & $\begin{array}{l}\text { Web page providing links to detailed information for 1997-2006 } \\
\text { on management and forecasts, as well as a news release updated } \\
\text { by ADFG on salmon, including run size and harvest by method. }\end{array}$ \\
\hline ADFG & $2006 \mathrm{c}$ & Alaska & Fishery & Shellfish & Website giving links to Alaska shellfish fishery information. \\
\hline ADFG & $2006 d$ & Togiak Bay & $\begin{array}{l}\text { Harvest, } \\
\text { management, } \\
\text { forecast }\end{array}$ & Pacific herring & $\begin{array}{l}\text { A website providing links to historical information on the Togiak } \\
\text { herring fishery, including annual management report, season } \\
\text { summary, announcements and updates, in-season harvest } \\
\text { summary, and preseason forecast. Covers } 1997-2005 \text {. }\end{array}$ \\
\hline $\mathrm{ADFG}$ & $2006 \mathrm{e}$ & Alaska & Distribution & Anadromous fishes & $\begin{array}{l}\text { ADFG catalog and map atlas of statewide anadromous waters } \\
\text { and maps, including the North Aleutian Basin. }\end{array}$ \\
\hline $\mathrm{ADFG}$ & $2006 f$ & Alaska & $\begin{array}{l}\text { Fishery } \\
\text { subsistence }\end{array}$ & General & $\begin{array}{l}\text { ADFG website with annual subsistence fisheries reports, 1999- } \\
2003 \text { (most recent report). }\end{array}$ \\
\hline $\begin{array}{l}\text { Adkinson } \\
\text { and Finney }\end{array}$ & 2003 & Bristol Bay & Fishery & Salmon & $\begin{array}{l}\text { Examines harvests and value of Bristol Bay salmon fisheries for } \\
\text { the years 1955-2003. Discusses causes of fluctuations and } \\
\text { forecasts of future returns. }\end{array}$ \\
\hline ADNR & $2005 a$ & $\begin{array}{l}\text { Alaska } \\
\text { Peninsula }\end{array}$ & General & General & $\begin{array}{l}\text { Generally describes freshwater and marine fishes and other fauna } \\
\text { of lease areas of the Alaska Peninsula. }\end{array}$ \\
\hline ADNR & $2005 b$ & Alaska & Distribution & Anadromous fish & $\begin{array}{l}\text { A table listing anadromous fish streams in Alaska indicating } \\
\text { species. }\end{array}$ \\
\hline ARRT & 2001 & Bristol Bay & $\begin{array}{l}\text { Distribution, } \\
\text { impacts }\end{array}$ & Fishery & $\begin{array}{l}\text { Describes distribution, habitats, and fishery of Bristol Bay. } \\
\text { Identifies sensitivity areas for oil spill contingency planning. }\end{array}$ \\
\hline
\end{tabular}


Table 2 (Cont.)

\begin{tabular}{|c|c|c|c|c|c|}
\hline Authors & Date & Location & Topic & Species & Document Content \\
\hline Aydin & 2002 & Bering Sea & Management & General & $\begin{array}{l}\text { Ecosim policy maximization routines were used to examine } \\
\text { fishing policies for a mid-1980s model of the eastern Bering Sea } \\
\text { shelf/slope ecosystem containing } 38 \text { functional groups and } \\
\text { including catch and bycatch. In addition to yield maximization, } \\
\text { the simulations explored "ecological" maximization (using the } \\
\text { 1/PB index discussed in the workshop as a criterion) and } \\
\text { examined mechanisms for increasing pinniped biomass through } \\
\text { selective prey manipulation, especially with respect to the } \\
\text { endangered Steller sea lion. }\end{array}$ \\
\hline AYK-SSI & 2006 & General & Population & Salmon & $\begin{array}{l}\text { This report addresses the trends and causes of variation in salmon } \\
\text { abundance and fisheries by assembling existing information, } \\
\text { gaining new information, and improving management and } \\
\text { restoration techniques through a collaborative and inclusive } \\
\text { process. Includes life history, populations, fisheries, and } \\
\text { subsistence, among others. }\end{array}$ \\
\hline Bailey & 2000 & General & $\begin{array}{l}\text { Ecology, } \\
\text { population }\end{array}$ & Walleye pollock & $\begin{array}{l}\text { Discusses factors influencing recruitment of walleye pollock. } \\
\text { Identifies a change from the importance of environmental factors } \\
\text { on larval fish to the importance of predation on juvenile fish by } \\
\text { cod and flatfish. }\end{array}$ \\
\hline Bailey et al. & 1997 & General & Population & Walleye pollock & Identifies factors in the population biology of walleye pollock. \\
\hline Bailey et al. & 2000 & General & $\begin{array}{l}\text { Ecology, } \\
\text { population }\end{array}$ & Walleye pollock & $\begin{array}{l}\text { Discusses factors affecting the population dynamics of walleye } \\
\text { pollock. }\end{array}$ \\
\hline Baker et al. & 2006 & Bristol Bay & Population & Salmon & $\begin{array}{l}\text { Escapement goals for sockeye, chinook, chum, coho, and pink } \\
\text { salmon for the Bristol Bay area. }\end{array}$ \\
\hline $\begin{array}{l}\text { Barnard and } \\
\text { Burt }\end{array}$ & 2006 & Bering Sea & Fishery & $\begin{array}{l}\text { Golden king crab, } \\
\text { scarlet king crab, snow } \\
\text { crab, grooved tanner } \\
\text { crab }\end{array}$ & $\begin{array}{l}\text { Summaries of data collected by observers for the } 2005 \text { pre- } \\
\text { rationalized BSAI crab fisheries in the Bering Sea, including } \\
\text { golden king crab, scarlet king crab, snow crab, and grooved } \\
\text { tanner crab. }\end{array}$ \\
\hline $\begin{array}{l}\text { Barnard and } \\
\text { Pengilley }\end{array}$ & 2006 & General & $\begin{array}{l}\text { Population, } \\
\text { fishery }\end{array}$ & Red king crab & $\begin{array}{l}\text { This study evaluated the effectiveness of the first season of the } \\
\text { federal Crab Rationalization Program to reduce bycatch of } \\
\text { females and juveniles. There was no indication that the first } \\
\text { season of the program reduced bycatch. Data supported a } \\
\text { conclusion of increased discarding of legal males. }\end{array}$ \\
\hline
\end{tabular}
abundance and fisheries by assembling existing information, gaining new information, and improving management and techniques through a collaborative and inclusive subsistence, among others.

Identifies a change from the importance of environmental factors 
Table 2 (Cont.)

\begin{tabular}{|c|c|c|c|c|c|}
\hline Authors & Date & Location & Topic & Species & Document Content \\
\hline Barnhart & 2006 & Bering Sea & $\begin{array}{l}\text { Management, } \\
\text { fishery }\end{array}$ & Weathervane scallop & $\begin{array}{l}\text { Annual management report for weathervane scallops, including } \\
\text { management, historic background, 2004/2005 fishery, and stock } \\
\text { status. }\end{array}$ \\
\hline $\begin{array}{l}\text { Barnhart } \\
\text { and } \\
\text { Rosenkranz }\end{array}$ & 2006 & Bering Sea & Fishery & Weathervane scallop & $\begin{array}{l}\text { Contains observer data for the } 2002 / 2003 \text { statewide weathervane } \\
\text { scallop fishery, including catch-and-effort and bycatch. }\end{array}$ \\
\hline $\begin{array}{l}\text { Blaylock } \\
\text { et al. }\end{array}$ & 2003 & $\begin{array}{l}\text { Eastern Pacific, } \\
\text { Bering Sea }\end{array}$ & Population & Halibut & $\begin{array}{l}\text { Statistical analysis of parasite data on fish collected from } \\
\text { California to the Bering Sea supports the conclusion that two } \\
\text { major groups of halibut exist and suggests the possibility of a } \\
\text { third group in the central and northern Bering Sea. }\end{array}$ \\
\hline Blood & 2002 & General & Population & Walleye pollock & $\begin{array}{l}\text { Laboratory study of development and time-to-hatching of } \\
\text { walleye pollock eggs. }\end{array}$ \\
\hline $\begin{array}{l}\text { Bond and } \\
\text { Overland }\end{array}$ & 2005 & Bering Sea & Ecology, climate & $\begin{array}{l}\text { Walleye pollock, tanner } \\
\text { crab }\end{array}$ & $\begin{array}{l}\text { Discusses the presumed effect of decadal climate variability on } \\
\text { recruitment of walleye pollock, tanner crabs, and } \\
\text { coccolithophorids. }\end{array}$ \\
\hline $\begin{array}{l}\text { Bowers } \\
\text { et al. }\end{array}$ & 2005 & $\begin{array}{l}\text { Bering Sea, } \\
\text { Bristol Bay }\end{array}$ & $\begin{array}{l}\text { Fishery, } \\
\text { management, } \\
\text { population }\end{array}$ & Shellfish & $\begin{array}{l}\text { Annual management report for commercial and subsistence } \\
\text { shellfish fishery for } 2004 / 2005 \text { contains information on the } \\
\text { Aleutian Islands and Bering Sea/Bristol Bay. Includes all species } \\
\text { of crabs, octopus, sea urchins, sea cucumbers, and snails. }\end{array}$ \\
\hline $\begin{array}{l}\text { Brodeur } \\
\text { et al. }\end{array}$ & 2003 & Bering Sea & $\begin{array}{l}\text { Distribution, } \\
\text { ecology }\end{array}$ & Salmon & $\begin{array}{l}\text { This article is an extensive literature review of research on the } \\
\text { movement, distribution, food resources, and other aspects of the } \\
\text { life history of juvenile salmon, including populations in the } \\
\text { eastern Bering Sea. }\end{array}$ \\
\hline Buklis & 1999 & Alaska & $\begin{array}{l}\text { Fishery, } \\
\text { socioeconomics }\end{array}$ & Salmon & $\begin{array}{l}\text { Discusses the economics of a mixed subsistence and commercial } \\
\text { salmon fishery subject to supply trends. Discusses impacts on } \\
\text { income. }\end{array}$ \\
\hline Byerly et al. & 1999 & Alaska & Fishery & Salmon & $\begin{array}{l}\text { Data on Alaska commercial salmon catches by species and area } \\
\text { from } 1878 \text { to } 1997 \text {. }\end{array}$ \\
\hline Callaway & 1997 & Alaska & $\begin{array}{l}\text { Fishing } \\
\text { communities, } \\
\text { subsistence }\end{array}$ & General & $\begin{array}{l}\text { Discusses the potential impact on subsistence communities of } \\
\text { climate change, on the basis of pre- } 1997 \text { data. }\end{array}$ \\
\hline
\end{tabular}


Table 2 (Cont.)

\begin{tabular}{|c|c|c|c|c|c|}
\hline Authors & Date & Location & Topic & Species & Document Content \\
\hline Cascorbi & 2004 & General & Management & Crabs & $\begin{array}{l}\text { Proposed guidelines for seafood choice based on conservation } \\
\text { concerns and support of sustainability goals. }\end{array}$ \\
\hline CFEC & 2004 & Alaska & Management & General & $\begin{array}{l}\text { Describes the decisions and activities of the Alaska Commercial } \\
\text { Fisheries Entry Commission for 2004, including adjudications, } \\
\text { licensing, research, and revenue. }\end{array}$ \\
\hline CFEC & 2005 & Alaska & Management & General & $\begin{array}{l}\text { Describes the decisions and activities of the Alaska Commercial } \\
\text { Fisheries Entry Commission for 2005, including adjudications, } \\
\text { licensing, research, and revenue. }\end{array}$ \\
\hline $\begin{array}{l}\text { Christian } \\
\text { et al. }\end{array}$ & 2003 & Bering Sea & Impacts & Snow crab & $\begin{array}{l}\text { Field and laboratory studies of the effects of seismic air guns on } \\
\text { the behavior and physiology of snow crabs were conducted with } \\
\text { Atlantic populations. }\end{array}$ \\
\hline Clark & $2005 a$ & $\begin{array}{l}\text { Bristol Bay, } \\
\text { Alagnak River }\end{array}$ & Distribution & Sockeye salmon & $\begin{array}{l}\text { Distribution of sockeye salmon in the Alagnak River system, of } \\
\text { Bristol Bay. }\end{array}$ \\
\hline Clark & $2005 b$ & Bristol Bay & Management & Salmon & $\begin{array}{l}\text { A review of the Bristol Bay salmon management program, } \\
\text { including stock assessment activities. }\end{array}$ \\
\hline $\begin{array}{l}\text { Connors } \\
\text { et al. }\end{array}$ & 2002 & Bering Sea & Ecology, climate & General & $\begin{array}{l}\text { This paper compiles data from bottom trawl surveys conducted } \\
\text { from 1963-2000. Time series are presented for three sites in the } \\
\text { southeastern Bering Sea. All three sites show strong evidence of } \\
\text { a shift in benthic biomass and community structure in the early to } \\
\text { mid-1980s. The data suggest that a complete reorganization of } \\
\text { benthic and demersal food webs may have taken place. The } \\
\text { timing of the shift is consistent with effects of the strong regime } \\
\text { shift observed in climate indices in 1976-1977. }\end{array}$ \\
\hline DeCicco & 2003 & Alaska & Management & General & $\begin{array}{l}\text { Fishery management in the northwest Alaska management area, } \\
\text { 2001-2003. Includes management programs and data on sport, } \\
\text { subsistence, and commercial fisheries. }\end{array}$ \\
\hline
\end{tabular}


Table 2 (Cont.)

\begin{tabular}{|c|c|c|c|c|c|}
\hline Authors & Date & Location & Topic & Species & Document Content \\
\hline Dieter et al. & 2003 & Worldwide & Fishery impacts & General & $\begin{array}{l}\text { Worldwide annotated bibliography of scientific and popular } \\
\text { literature on demersal, mobile fishing gear and its effects in } \\
\text { marine ecosystems. The primary focus is bottom trawling, } \\
\text { dredging, and raking, and the resulting direct disturbance of } \\
\text { marine habitats and associated biological communities. Papers } \\
\text { addressing other topics, such as bycatch and discards, and } \\
\text { seafloor impacts of marine aggregates dredging and gravel } \\
\text { extraction, are also referenced. Papers discussing impacts from } \\
\text { other activities, such as longline fishing, trapping, use of } \\
\text { chemicals, and dynamite blasting, are not referenced. }\end{array}$ \\
\hline DOC & 1997 & Alaska & $\begin{array}{l}\text { Management, } \\
\text { fishery impacts }\end{array}$ & Groundfish & $\begin{array}{l}\text { Rule establishing exclusive zones for hook-and-line groundfish } \\
\text { fisheries to control seabird bycatch is discussed. }\end{array}$ \\
\hline DOC & 1998 & Alaska & Management & Halibut & $\begin{array}{l}\text { Regulations to reduce seabird bycatch by halibut fisheries are } \\
\text { described. }\end{array}$ \\
\hline $\begin{array}{l}\text { Downton } \\
\text { and Miller }\end{array}$ & 1998 & Alaska & Fishery & Salmon & $\begin{array}{l}\text { Using multivariate time series models, Alaska's statewide } \\
\text { commercial catch of three salmon species during 1925-1994 is } \\
\text { shown to be related to surface temperatures in particular large } \\
\text { regions of the eastern North Pacific }\end{array}$ \\
\hline DuBois & 2002 & $\begin{array}{l}\text { Arctic-Yukon- } \\
\text { Kuskokwim } \\
\text { Delta }\end{array}$ & Population & Pacific herring & $\begin{array}{l}\text { Report on Pacific herring stocks of the Arctic-Yukon- } \\
\text { Kuskokwim Delta region of the Bering Sea. }\end{array}$ \\
\hline DuBois & 2003 & $\begin{array}{l}\text { Arctic-Yukon- } \\
\text { Kuskokwim } \\
\text { Delta }\end{array}$ & Population & Pacific herring & $\begin{array}{l}\text { Report on the age, sex, and size composition of Pacific herring } \\
\text { from coastal spawning sites in the Arctic-Yukon-Kuskokwim } \\
\text { region. }\end{array}$ \\
\hline $\begin{array}{l}\text { Duffield } \\
\text { et al. }\end{array}$ & 2007 & Bristol Bay & $\begin{array}{l}\text { Socioeconomics, } \\
\text { subsistence }\end{array}$ & Salmon & $\begin{array}{l}\text { This report provides estimates of the economic values associated } \\
\text { with sustainable use of wild salmon ecosystem resources, } \\
\text { primarily fisheries and wildlife, of the major watersheds of the } \\
\text { Bristol Bay region. Both regional economic significance and } \\
\text { social benefit-cost accounting frameworks were considered. This } \\
\text { study reviews and summarizes existing economic research on the } \\
\text { key sectors in this area and reports findings based on the original } \\
\text { survey data on expenditures, net benefits, attitudes, and } \\
\text { motivations of the angler population. }\end{array}$ \\
\hline
\end{tabular}

ishery impacts

Fishery

Salmon

motivations of the angler population. 
Table 2 (Cont.)

\begin{tabular}{|c|c|c|c|c|c|}
\hline Authors & Date & Location & Topic & Species & Document Content \\
\hline $\begin{array}{l}\text { Duffy- } \\
\text { Anderson et } \\
\text { al. }\end{array}$ & 2006 & $\begin{array}{l}\text { Eastern Bering } \\
\text { Sea }\end{array}$ & Distribution & Larval fish & $\begin{array}{l}\text { Spatial and temporal patterns of larval and early juvenile fishes } \\
\text { from the eastern Bering Sea were examined and float trajectories } \\
\text { modeled for samples collected during summers 1996-2000. }\end{array}$ \\
\hline $\begin{array}{l}\text { Dunaway } \\
\text { and } \\
\text { Sonnichsen }\end{array}$ & 2001 & Alaska & $\begin{array}{l}\text { Fishery } \\
\text { management }\end{array}$ & General & $\begin{array}{l}\text { Sport fishery management report for } 1999 \text {. Discusses } \\
\text { management plans affecting fish, major issues, ongoing research } \\
\text { and management, access programs and outreach programs. } \\
\text { Discusses sport fishing effort. For each species, this report } \\
\text { describes fishery history, historical performance, management, } \\
\text { the } 1999 \text { fishery, and outlook for } 2000 \text {. }\end{array}$ \\
\hline Dye et al. & 2006 & Bristol Bay & $\begin{array}{l}\text { Fishery, } \\
\text { management }\end{array}$ & Salmon & $\begin{array}{l}\text { This report summarizes Bristol Bay sport fisheries during } 2006 . \\
\text { Fisheries include Alagnak and Nushagak/Mulchatna Chinook } \\
\text { salmon, Kvichak sockeye salmon, lower Talarik Creek and upper } \\
\text { Nushagak River rainbow trout, and northern pike. The sport } \\
\text { fisheries are described, and estimates of sport effort, catch, and } \\
\text { harvest, and escapement are provided. Overviews of management } \\
\text { for each fishery are provided, such as pertinent sport fishing } \\
\text { regulations and management plans. }\end{array}$ \\
\hline $\begin{array}{l}\text { Failor- } \\
\text { Rounds }\end{array}$ & 2005 & Alaska & Fishery & $\begin{array}{l}\text { Sablefish, black } \\
\text { rockfish, Greenland } \\
\text { turbot, arrowtooth } \\
\text { flounder, rock sole, } \\
\text { yellowfin sole }\end{array}$ & $\begin{array}{l}\text { Contains a description of the historic background, the } 2004 \\
\text { fishery, and stock status for the Aleutian Islands sablefish and } \\
\text { black rockfish fishery. Also gives harvest data for Greenland } \\
\text { turbot, arrowtooth flounder, rock sole, yellowfin sole, and other } \\
\text { flatfish. }\end{array}$ \\
\hline $\begin{array}{l}\text { Fall and } \\
\text { Krieg }\end{array}$ & 2006 & Bristol Bay & $\begin{array}{l}\text { Fishery, } \\
\text { subsistence }\end{array}$ & General & $\begin{array}{l}\text { Discusses the subsistence fishery of Bristol Bay, including } \\
\text { permits, species, and catch. }\end{array}$ \\
\hline Farley et al. & 2003 & $\begin{array}{l}\text { Bering Sea, } \\
\text { Bristol Bay }\end{array}$ & $\begin{array}{l}\text { Distribution, } \\
\text { population }\end{array}$ & Salmon & $\begin{array}{l}\text { The numbers, distribution, and age composition of juvenile } \\
\text { salmon were estimated from fall surveys of the eastern Bering } \\
\text { shelf, including Bristol Bay. }\end{array}$ \\
\hline Finney et al. & 2000 & General & Population & Salmon & $\begin{array}{l}\text { Lake sediment records and biological indicators were used to } \\
\text { construct a } 300 \text {-year record of sockeye abundance. }\end{array}$ \\
\hline $\begin{array}{l}\text { Flint and } \\
\text { Miles }\end{array}$ & 2002 & Alaska & Fishery impacts & General & $\begin{array}{l}\text { Describes the relationship between boat harbors, fish processing, } \\
\text { organic contamination, and Steller's eiders. }\end{array}$ \\
\hline
\end{tabular}


Table 2 (Cont.)

\begin{tabular}{|c|c|c|c|c|c|}
\hline Authors & Date & Location & Topic & Species & Document Content \\
\hline $\begin{array}{l}\text { Flynn and } \\
\text { Hilborn }\end{array}$ & 2004 & $\begin{array}{l}\text { Port Moller, } \\
\text { Bristol Bay }\end{array}$ & $\begin{array}{l}\text { Fishery } \\
\text { management }\end{array}$ & Sockeye salmon & $\begin{array}{l}\text { Examined variability in indices for forecasting sockeye salmon } \\
\text { run size. Correcting models for age composition, migration route, } \\
\text { and timing may decrease error by as much as } 10 \% \text {. }\end{array}$ \\
\hline Flynn et al. & 2003 & Bristol Bay & Distribution & Sockeye salmon & $\begin{array}{l}\text { Presents a model using age composition data to identify spatial } \\
\text { distribution of component stocks migrating to Bristol Bay. }\end{array}$ \\
\hline FWS & 1998 & $\begin{array}{l}\text { Bering Sea, } \\
\text { Aleutian Islands }\end{array}$ & $\begin{array}{l}\text { Management, } \\
\text { fishery impacts }\end{array}$ & Halibut & $\begin{array}{l}\text { Biological opinion on the effects of the Bering Sea/Aleutian } \\
\text { Islands halibut fishery on the short-tailed albatross. }\end{array}$ \\
\hline FWS & 1999 & $\begin{array}{l}\text { Bering Sea, } \\
\text { Gulf of Alaska, } \\
\text { Aleutian Islands }\end{array}$ & $\begin{array}{l}\text { Management, } \\
\text { fishery impacts }\end{array}$ & Groundfish & $\begin{array}{l}\text { Endangered Species Act Section } 7 \text { consultation for the 1999- } \\
2000 \text { hook-and-line groundfish fisheries of the Gulf of Alaska, } \\
\text { Bering Sea, and Aleutian Islands area. }\end{array}$ \\
\hline FWS & 2001 & Alaska & $\begin{array}{l}\text { Fishery, } \\
\text { subsistence }\end{array}$ & General & $\begin{array}{l}2000 \text { Fisheries Resource Monitoring Plan status report to the } \\
\text { Regional Advisory Councils and Federal Subsistence Board. }\end{array}$ \\
\hline $\begin{array}{l}\text { Gharrett } \\
\text { et al. }\end{array}$ & 2001 & Alaska & Population & Salmon & $\begin{array}{l}\text { Genetic variability in coho salmon was measured for Bering Sea } \\
\text { and Gulf of Alaska stocks. }\end{array}$ \\
\hline Gillispie & 1997 & Arctic & Ecology & Arctic cod & Thesis on the biology and ecology of the arctic cod. \\
\hline Gravel et al. & 2006 & General & Population & Snow crab & $\begin{array}{l}\text { Over } 8,000 \text { large male snow crabs were tagged. Gender, size, } \\
\text { frequency, and catch per unit were recorded. }\end{array}$ \\
\hline Gunderson & $1996 \mathrm{a}$ & General & Ecology & Walleye pollock & Discusses the ecology of juvenile walleye pollock. \\
\hline Gunderson & $1996 b$ & General & General & Walleye pollock & Identifies research priorities related to juvenile walleye pollock. \\
\hline $\begin{array}{l}\text { Hammond } \\
\text { et al. }\end{array}$ & 2001 & Bering Sea & Fishery & Walleye pollack & $\begin{array}{l}\text { Applies a Bayesian spatial composition estimation tool to Bering } \\
\text { Sea acoustic fish survey data to determine applicability for } \\
\text { estimating abundance ratios of juvenile and adult fish. The results } \\
\text { suggest the tool may be usefully applied to actual surveys. }\end{array}$ \\
\hline $\begin{array}{l}\text { Hart and } \\
\text { van } \\
\text { Tamelen }\end{array}$ & 2002 & Alaska & General & Shellfish & User's guide to the ADFG's literature database on shellfish. \\
\hline Hoff & 2000 & Bristol Bay & Ecology & Threaded sculpin & $\begin{array}{l}\text { Describes the biology and ecology of the threaded sculpin, a } \\
\text { shallow-water fish found in Bristol Bay and other waters of the } \\
\text { North Pacific. }\end{array}$ \\
\hline
\end{tabular}


Table 2 (Cont.)

\begin{tabular}{|c|c|c|c|c|c|}
\hline Authors & Date & Location & Topic & Species & Document Content \\
\hline Jackson & 2006 & $\begin{array}{l}\text { Alaska } \\
\text { Peninsula, } \\
\text { Aleutian Islands }\end{array}$ & Fishery & Pacific herring & $\begin{array}{l}\text { History, harvest strategy, and catch of Pacific herring in the } \\
\text { Alaska Peninsula and Aleutian Islands Management Area for } \\
2005 .\end{array}$ \\
\hline $\begin{array}{l}\text { Jackson and } \\
\text { Poetter }\end{array}$ & 2006 & $\begin{array}{l}\text { Alaska } \\
\text { Peninsula, } \\
\text { Aleutian Islands }\end{array}$ & Fishery & Pacific herring & $\begin{array}{l}\text { Describes the herring fishery for 2004, 2005, and } 2006 \text { for the } \\
\text { Alaska Peninsula and Aleutian Islands Management Area. }\end{array}$ \\
\hline Jewett & 1999 & General & Impacts & Crabs & Evaluates effects of offshore placer mining. \\
\hline $\begin{array}{l}\text { Jewett and } \\
\text { Naidu }\end{array}$ & 2000 & Norton Sound & Impacts & Red crab & $\begin{array}{l}\text { Measured heavy metals in tissue and organs of red crab in Norton } \\
\text { Sound to study effects of offshore placer mining. }\end{array}$ \\
\hline Jewett et al. & 2003 & Alaska & Impacts & $\begin{array}{l}\text { Arctic grayling, } \\
\text { northern pike, and } \\
\text { whitefish }\end{array}$ & $\begin{array}{l}\text { Mercury concentrations in the flesh of Arctic grayling, northern } \\
\text { pike, and whitefish were measured and human health } \\
\text { implications evaluated. }\end{array}$ \\
\hline $\begin{array}{l}\text { Johnson and } \\
\text { Wiess }\end{array}$ & 2006 & $\begin{array}{l}\text { Alaska } \\
\text { Peninsula, } \\
\text { Bristol Bay }\end{array}$ & Distribution & Anadromous fish & $\begin{array}{l}\text { Lists anadromous fish for the lakes and streams of the southwest } \\
\text { region of Alaska, which includes the Alaska Peninsula and } \\
\text { Bristol Bay. }\end{array}$ \\
\hline King & 2005 & Bering Sea & Ecology, climate & General & $\begin{array}{l}\text { This report includes a section on climate shifts in the Bering Sea } \\
\text { and subsequent effects on fish communities. }\end{array}$ \\
\hline $\begin{array}{l}\text { Logerwell } \\
\text { et al. }\end{array}$ & 2005 & Aleutian Islands & $\begin{array}{l}\text { Distribution, } \\
\text { ecology }\end{array}$ & Demersal fish & $\begin{array}{l}\text { Discusses the composition and distribution of demersal fish } \\
\text { populations and communities in the Aleutian Islands region. } \\
\text { Food habits and growth of these species are also discussed. }\end{array}$ \\
\hline $\begin{array}{l}\text { Loher and } \\
\text { Armstrong }\end{array}$ & 2005 & Bering Sea & Population & King crab & $\begin{array}{l}\text { Distribution and abundance of ovigerous females were } \\
\text { investigated using trawl surveys from } 1975 \text { to } 2001 \text {. Near-bottom } \\
\text { temperatures are presented for } 1974-2001 \text {. It is suggested that } \\
\text { temperature may be an important factor in the distribution of this } \\
\text { species. }\end{array}$ \\
\hline Loher et al. & 2001 & $\begin{array}{l}\text { Aleutian } \\
\text { Islands, Gulf of } \\
\text { Alaska }\end{array}$ & Population & Red king crab & $\begin{array}{l}\text { Presents in situ growth rate of juvenile red king crabs, } \\
\text { comparisons to Unalaska and Kodiak Islands, and a primarily } \\
\text { pre-1996 reference list. }\end{array}$ \\
\hline
\end{tabular}


Table 2 (Cont.)

\begin{tabular}{|c|c|c|c|c|c|}
\hline Authors & Date & Location & Topic & Species & Document Content \\
\hline $\begin{array}{l}\text { Lovvren } \\
\text { et al. }\end{array}$ & 2005 & Bering Sea & $\begin{array}{l}\text { Ecology, } \\
\text { oceanography }\end{array}$ & $\begin{array}{l}\text { General, planktonic } \\
\text { fish, benthic fish }\end{array}$ & $\begin{array}{l}\text { Production from spring blooms at the retreating ice edge may } \\
\text { sink to the bottom with little grazing by zooplankton, thereby } \\
\text { supporting abundant benthic communities. This report discusses } \\
\text { organic matter pathways to macrobenthos and macrozooplankton } \\
\text { under ice cover in late winter (March-April) and open water in } \\
\text { late summer (September) in the north-central Bering Sea. }\end{array}$ \\
\hline $\begin{array}{l}\text { Lowe and } \\
\text { Fritz }\end{array}$ & 1997 & $\begin{array}{l}\text { Alaska } \\
\text { Peninsula }\end{array}$ & Fishery & Groundfish & $\begin{array}{l}\text { Projects groundfish stocks and fishery potential for the Aleutian } \\
\text { Island region for } 1998 .\end{array}$ \\
\hline $\begin{array}{l}\text { McDermott } \\
\text { et al. }\end{array}$ & 2005 & Aleutian Islands & $\begin{array}{l}\text { Population, } \\
\text { ecology }\end{array}$ & Atka mackerel & $\begin{array}{l}\text { Tag-recapture methods were used to estimate populations and } \\
\text { movement of Atka mackerel in the Aleutian Islands. Life history } \\
\text { of this fish is also discussed. }\end{array}$ \\
\hline $\begin{array}{l}\text { McNair and } \\
\text { Holder }\end{array}$ & 2000 & $\begin{array}{l}\text { Arctic-Yukon- } \\
\text { Kuskokwim } \\
\text { Delta }\end{array}$ & Population & Salmon & $\begin{array}{l}\text { Lists by release site all the salmon releases in the Alaska-Yukon- } \\
\text { Kuskokwim area. }\end{array}$ \\
\hline $\begin{array}{l}\text { Mecklen- } \\
\text { burg et al. }\end{array}$ & 2002 & Alaska & General & General & $\begin{array}{l}\text { A comprehensive guide to the fishes of Alaska. Includes } \\
\text { identification keys, family and species accounts, morphological } \\
\text { features, geographic range, and an extensive bibliography. }\end{array}$ \\
\hline Megrey & 1996 & General & $\begin{array}{l}\text { Ecology, } \\
\text { population }\end{array}$ & Walleye pollock & $\begin{array}{l}\text { Discusses the relationship of juvenile walleye pollock abundance } \\
\text { to adult recruitment and linkages with the environment. }\end{array}$ \\
\hline $\begin{array}{l}\text { Merrick and } \\
\text { Calkins }\end{array}$ & 1996 & General & Ecology & Walleye pollock & $\begin{array}{l}\text { Discusses the importance of walleye pollock in the diet of Steller } \\
\text { sea lions. }\end{array}$ \\
\hline $\begin{array}{l}\text { Meyers } \\
\text { et al. }\end{array}$ & 1996 & Alaska & Disease & Tanner crab & $\begin{array}{l}\text { Provides results of bitter crab syndrome surveys from } 1988 \text { to } \\
1991 .\end{array}$ \\
\hline MMS & 2004 & General & Impacts & General & $\begin{array}{l}\text { A study of the drift gillnet fishery and oil/gas interactions and } \\
\text { mitigation possibilities. }\end{array}$ \\
\hline $\begin{array}{l}\text { Moles and } \\
\text { Norcross }\end{array}$ & 1998 & General & Impacts & Flatfishes & Discusses the effects of oil-laden sediments on flatfishes. \\
\hline $\begin{array}{l}\text { Morstad } \\
\text { and Baker }\end{array}$ & 2006 & Kvichak River & Management & Salmon & $\begin{array}{l}\text { Discusses management and regulatory history, stock status, and } \\
\text { review and development of an action plan for sockeye salmon in } \\
\text { the Kvichak River. }\end{array}$ \\
\hline
\end{tabular}


Table 2 (Cont.)

\begin{tabular}{|c|c|c|c|c|c|}
\hline Authors & Date & Location & Topic & Species & Document Content \\
\hline $\begin{array}{l}\text { Mueter } \\
\text { et al. }\end{array}$ & 2006 & $\begin{array}{l}\text { Eastern Bering } \\
\text { Sea }\end{array}$ & $\begin{array}{l}\text { Management, } \\
\text { population }\end{array}$ & Walleye pollack & $\begin{array}{l}\text { Presents statistical analyses of leading hypotheses linking } \\
\text { recruitment variability to biotic and abiotic factors. The results } \\
\text { support the cold-pool hypothesis that recruitment is significantly } \\
\text { stronger when winter preceding the age- } 0 \text { and age- } 1 \text { stages is } \\
\text { mild. }\end{array}$ \\
\hline Mundy & 1998 & Alaska & $\begin{array}{l}\text { Management, } \\
\text { sustainability }\end{array}$ & Salmon & $\begin{array}{l}\text { A detailed discussion of the principles and criteria for sustainable } \\
\text { salmon management. }\end{array}$ \\
\hline Murphy & 2005 & $\begin{array}{l}\text { Alaska } \\
\text { Peninsula }\end{array}$ & Management & Groundfish & $\begin{array}{l}\text { Defines the } 2005 \text { fishery management plan for areas including } \\
\text { the north Alaska Peninsula. }\end{array}$ \\
\hline $\begin{array}{l}\text { Murphy and } \\
\text { Tschersich }\end{array}$ & 2005 & $\begin{array}{l}\text { Alaska } \\
\text { Peninsula }\end{array}$ & Management & Salmon & $\begin{array}{l}\text { Defines the } 2006 \text { salmon management plan for the north Alaska } \\
\text { Peninsula area. }\end{array}$ \\
\hline $\begin{array}{l}\text { Murphy and } \\
\text { Tschersich }\end{array}$ & 2006 & $\begin{array}{l}\text { Alaska } \\
\text { Peninsula }\end{array}$ & $\begin{array}{l}\text { Population, } \\
\text { fishery }\end{array}$ & Salmon & $\begin{array}{l}\text { Salmon escapement and harvest data for the north Alaska } \\
\text { Peninsula area. }\end{array}$ \\
\hline $\begin{array}{l}\text { Murphy et } \\
\text { al. }\end{array}$ & 1999 & $\begin{array}{l}\text { Prince William } \\
\text { Sound }\end{array}$ & Impacts & Salmon & $\begin{array}{l}\text { Discusses recovery of pink salmon spawning habitat after the } \\
\text { Exxon Valdez oil spill. }\end{array}$ \\
\hline Myers et al. & 2000 & General & Population & Salmon & Presents factors affecting the ocean production of salmon. \\
\hline $\begin{array}{l}\text { Napp and } \\
\text { Hunt }\end{array}$ & 2001 & Bering Sea & Ecology, climate & General & Discusses linkages among climate, weather, ocean, and biology. \\
\hline Napp et al. & 2000 & General & Ecology & Walleye pollock & $\begin{array}{l}\text { Discusses the biological and physical processes affecting the } \\
\text { feeding environment of larval walleye pollock. }\end{array}$ \\
\hline $\begin{array}{l}\text { Nelson } \\
\text { et al. }\end{array}$ & 2006 & $\begin{array}{l}\text { Alaska } \\
\text { Peninsula }\end{array}$ & Management & Salmon & $\begin{array}{l}\text { Discusses escapement goals for the Aleutian Peninsula and } \\
\text { Aleutian Islands Management Areas. }\end{array}$ \\
\hline NMFS & 2001 & $\begin{array}{l}\text { Bering Sea, } \\
\text { Gulf of Alaska, } \\
\text { Aleutian Islands }\end{array}$ & $\begin{array}{l}\text { Management, } \\
\text { fishery impacts }\end{array}$ & Groundfish & $\begin{array}{l}\text { Biological opinion regarding incidental take from groundfish } \\
\text { fisheries. }\end{array}$ \\
\hline NMFS & 2003 & $\begin{array}{l}\text { Bering Sea, } \\
\text { Gulf of Alaska, } \\
\text { Aleutian Islands }\end{array}$ & $\begin{array}{l}\text { Management, } \\
\text { fishery impacts }\end{array}$ & Groundfish & $\begin{array}{l}\text { Supplement to the } 2001 \text { biological opinion and incidental take } \\
\text { from groundfish fisheries. }\end{array}$ \\
\hline NMFS & 2006 & General & Fishery impacts & General & $\begin{array}{l}\text { Draft summary table from stock assessment report, including } \\
\text { estimates of mortality of marine mammals due to fisheries. }\end{array}$ \\
\hline NPFMC & 2006 & Alaska & Management & Multiple & Website for the North Pacific Fisheries Management Council. \\
\hline
\end{tabular}


Table 2 (Cont.)

\begin{tabular}{|c|c|c|c|c|c|}
\hline Authors & Date & Location & Topic & Species & Document Content \\
\hline $\begin{array}{l}\text { O’Connell } \\
\text { et al. }\end{array}$ & 1998 & $\begin{array}{l}\text { Bering Sea, } \\
\text { Prince William } \\
\text { Sound }\end{array}$ & Population & Pacific herring & $\begin{array}{l}\text { Genetic variability of Pacific herring was measured for } \\
\text { populations from the Bering Sea to Prince William Sound. }\end{array}$ \\
\hline Olsen & 2002 & General & Population & Walleye pollock & $\begin{array}{l}\text { An examination of spatial and temporal genetic variation in } \\
\text { walleye pollock. }\end{array}$ \\
\hline $\begin{array}{l}\text { Oswood } \\
\text { et al. }\end{array}$ & 2000 & Alaska & Distribution & Freshwater fish & Biogeography of the freshwater fishes of Alaska. \\
\hline Paul & 2000 & Bering Sea & General & Snow crab & A 46-page bibliography on the snow crab. \\
\hline Paul et al. & 2002 & General & $\begin{array}{l}\text { Ecology, } \\
\text { management }\end{array}$ & Crabs & $\begin{array}{l}\text { Collection of papers on crabs in coldwater regions, and their } \\
\text { biology, management, and economics. }\end{array}$ \\
\hline Peterson & 2000 & $\begin{array}{l}\text { Prince William } \\
\text { Sound }\end{array}$ & Impacts & General & $\begin{array}{l}\text { A critique of previous studies on the effects of the Exxon Valdez } \\
\text { oil spill. }\end{array}$ \\
\hline $\begin{array}{l}\text { Rugolo } \\
\text { et al. }\end{array}$ & 2006 & Bering Sea & $\begin{array}{l}\text { Distribution, } \\
\text { population }\end{array}$ & Red king crab & $\begin{array}{l}\text { Detailed results of trawl surveys of distribution and abundance of } \\
\text { red king crab (Bristol Bay and Pribilof districts), blue king crab } \\
\text { (Pribilof and Northern districts), tanner crab (Southern district), } \\
\text { snow crab (all districts), and hair crab (all districts). }\end{array}$ \\
\hline Salomone & 2006 & Bristol Bay & Fishery & Salmon & $\begin{array}{l}\text { A summary of effort and harvest of sockeye salmon for Bristol } \\
\text { Bay in 2001-2006. }\end{array}$ \\
\hline Sands & 2006 & Bristol Bay & Fishery & Salmon & $\begin{array}{l}\text { A summary of the Bristol Bay commercial salmon fishery in } \\
2004-2006 \text {. }\end{array}$ \\
\hline $\begin{array}{l}\text { Schabets- } \\
\text { berger et al. }\end{array}$ & 1999 & General & Population & Walleye pollock & Discusses egg cannibalism in walleye pollock. \\
\hline $\begin{array}{l}\text { Schumacher } \\
\text { and Kruse }\end{array}$ & 2005 & General & $\begin{array}{l}\text { Management, } \\
\text { sustainability }\end{array}$ & General & Examination of issues related to sustainable ecosystem services. \\
\hline $\begin{array}{l}\text { Seeb and } \\
\text { Crane }\end{array}$ & 1999 & $\begin{array}{l}\text { Southwest } \\
\text { Alaska }\end{array}$ & Population & Salmon & $\begin{array}{l}\text { Genetic relationships between } 64 \text { populations of chum salmon in } \\
\text { southwestern Alaska. }\end{array}$ \\
\hline Sepez et al. & 2005 & Alaska & $\begin{array}{l}\text { Fishery, } \\
\text { socioeconomics }\end{array}$ & General & $\begin{array}{l}\text { Social and economic profiles of } 136 \text { fishing communities in } \\
\text { Alaska based on } 2000 \text { data. Included are people and places } \\
\text { (location, demographics, education, local housing, and local } \\
\text { history), community infrastructure (current economic activity, } \\
\text { governance, and facilities), and involvement in North Pacific } \\
\text { fisheries (commercial, subsistence, and recreational fishing). }\end{array}$ \\
\hline
\end{tabular}


Table 2 (Cont.)

\begin{tabular}{|c|c|c|c|c|c|}
\hline Authors & Date & Location & Topic & Species & Document Content \\
\hline Spalinger & 2006 & $\begin{array}{l}\text { Alaska } \\
\text { Peninsula, } \\
\text { Aleutian } \\
\text { Islands, Gulf of } \\
\text { Alaska }\end{array}$ & Population & $\begin{array}{l}\text { Shellfish, groundfish, } \\
\text { walleye pollock }\end{array}$ & $\begin{array}{l}\text { Includes data from trawl surveys of the Kodiak, South Peninsula, } \\
\text { and Eastern Aleutian Management Districts for June-September } \\
\text { 2005. Species surveyed included tanner crab and red king crab. } \\
\text { Average haul weight and composition of fish and invertebrates } \\
\text { were measured. Groundfish included flathead sole, arrowtooth } \\
\text { flounder, and walleye pollock. }\end{array}$ \\
\hline Stehn et al. & 2001 & Alaskan waters & Fishery impacts & General & Discusses incidental catch of seabirds by longline fisheries. \\
\hline Trudel & 2002 & Bering Sea & Ecology & Salmon & Discusses sea lice on pink salmon. \\
\hline Tschersich & 2006 & $\begin{array}{l}\text { Alaska } \\
\text { Peninsula, } \\
\text { Aleutian } \\
\text { Islands, Atka- } \\
\text { Amelia Islands }\end{array}$ & Management & General & $\begin{array}{l}\text { Summarizes the } 2005 \text { season and historical information } \\
\text { concerning management of subsistence and commercial fisheries } \\
\text { of the Alaska Peninsula, Aleutian Islands, and Atka-Amelia } \\
\text { Islands. }\end{array}$ \\
\hline $\begin{array}{l}\text { Tschersich } \\
\text { and Foster }\end{array}$ & 2006 & $\begin{array}{l}\text { Alaska } \\
\text { Peninsula, } \\
\text { Aleutian Islands }\end{array}$ & Population & Salmon & $\begin{array}{l}\text { Presents Alaska Peninsula and Aleutian Islands Management } \\
\text { Areas escapement and catch sampling results. }\end{array}$ \\
\hline $\begin{array}{l}\text { van Tamelen } \\
\text { and Woodby }\end{array}$ & 2003 & General & General & Crabs & $\begin{array}{l}\text { Presents the agenda of the December } 11-13,2002 \text {, meeting on } \\
\text { crab research. Gives a brief bulleted summary of presentations. }\end{array}$ \\
\hline $\begin{array}{l}\text { Vining and } \\
\text { Zheng }\end{array}$ & 2006 & Bristol Bay & Population & Red king crab & $\begin{array}{l}\text { Provides population estimates for red king crab in Bristol Bay } \\
(1972-2005) .\end{array}$ \\
\hline $\begin{array}{l}\text { Webb and } \\
\text { Woodby }\end{array}$ & 2006 & General & General & Crabs & $\begin{array}{l}\text { Summary of the interagency crab research meeting, December } \\
14-16,2005 \text {. }\end{array}$ \\
\hline West & 2006 & Bristol Bay & Population & Salmon & $\begin{array}{l}\text { Drift gillnets were used in the Kvichak, Egegik, and Ugashik } \\
\text { Rivers to estimate in river abundance. Travel times were } \\
\text { estimated. }\end{array}$ \\
\hline $\begin{array}{l}\text { West and } \\
\text { Fair }\end{array}$ & 2006 & Bristol Bay & Population & Salmon & $\begin{array}{l}\text { Abundance, age, size, and gender statistics for Bristol Bay in } \\
2003 \text {. }\end{array}$ \\
\hline $\begin{array}{l}\text { Westing } \\
\text { et al. }\end{array}$ & 2005 & Bristol Bay & Fishery & General & $\begin{array}{l}\text { A detailed description for } 2004 \text { of the Bristol Bay commercial } \\
\text { and subsistence salmon fisheries and the herring fisheries. }\end{array}$ \\
\hline $\begin{array}{l}\text { Westing } \\
\text { et al. }\end{array}$ & $2006 a$ & Bristol Bay & Fishery & Pacific herring & A review of the Togiak herring fisheries of Bristol Bay. \\
\hline
\end{tabular}


Table 2 (Cont.)

\begin{tabular}{|c|c|c|c|c|c|}
\hline Authors & Date & Location & Topic & Species & Document Content \\
\hline $\begin{array}{l}\text { Westing } \\
\text { et al. }\end{array}$ & $2006 b$ & Bristol Bay & Fishery & Salmon, Pacific herring & $\begin{array}{l}\text { A detailed description for } 2005 \text { of the Bristol Bay commercial } \\
\text { and subsistence salmon fisheries and the herring fisheries. }\end{array}$ \\
\hline Williams & 1998 & General & Distribution & Salmon & $\begin{array}{l}\text { Discusses a recent review of a } 40 \text {-year database that examines } \\
\text { how fluctuating water temperatures affect the distribution of } \\
\text { salmon. }\end{array}$ \\
\hline Williams & 1999 & General & $\begin{array}{l}\text { Population, } \\
\text { ecology }\end{array}$ & Pacific herring & $\begin{array}{l}\text { Discusses interrelationships of Pacific herring populations and } \\
\text { large-scale environmental and oceanographic variables. }\end{array}$ \\
\hline $\begin{array}{l}\text { Williams } \\
\text { and Quinn }\end{array}$ & 1998 & General & Population & General & $\begin{array}{l}\text { Presents a parametric bootstrap method for estimating catch-age } \\
\text { compositions. }\end{array}$ \\
\hline Witherell & 1999 & Bering Sea & $\begin{array}{l}\text { Management, } \\
\text { ecology }\end{array}$ & Groundfish & $\begin{array}{l}\text { Discusses incorporating ecosystem considerations into the } \\
\text { management of Bering Sea groundfish fisheries. }\end{array}$ \\
\hline $\begin{array}{l}\text { Wolfe and } \\
\text { Utermohl }\end{array}$ & 2000 & Alaska & $\begin{array}{l}\text { Fishery, } \\
\text { subsistence }\end{array}$ & General & Estimates wild food consumption for rural Alaska populations. \\
\hline $\begin{array}{l}\text { Wyllie- } \\
\text { Escheverria }\end{array}$ & 1997 & Bering Sea & $\begin{array}{l}\text { Distribution, } \\
\text { oceanography }\end{array}$ & $\begin{array}{l}\text { General, walleye } \\
\text { pollock }\end{array}$ & Discusses sea ice and fish distribution in the Bering Sea. \\
\hline $\begin{array}{l}\text { Wyllie- } \\
\text { Escheverria } \\
\text { and Ohtani }\end{array}$ & 1999 & Bering Sea & $\begin{array}{l}\text { Ecology, } \\
\text { oceanography }\end{array}$ & $\begin{array}{l}\text { General, walleye } \\
\text { pollock }\end{array}$ & Discusses sea ice variability and the Bering Sea ecosystem. \\
\hline $\begin{array}{l}\text { Wyllie- } \\
\text { Escheverria } \\
\text { and } \\
\text { Wooster }\end{array}$ & 1998 & Bering Sea & $\begin{array}{l}\text { Ecology, } \\
\text { oceanography, } \\
\text { distribution }\end{array}$ & General & $\begin{array}{l}\text { Year-to-year variations in Bering Sea sea ice and some } \\
\text { consequences for fish distributions. }\end{array}$ \\
\hline Zheng & 2003 & General & Management & Red king crab & $\begin{array}{l}\text { Evaluates alternative harvest strategies based on simulation } \\
\text { modeling of } 2002 \text { population status. }\end{array}$ \\
\hline $\begin{array}{l}\text { Zheng and } \\
\text { Kruse }\end{array}$ & 2005 & Bering Sea & Population & Crabs & $\begin{array}{l}\text { Presentation on ecosystem effects on Bering Sea crab } \\
\text { populations. }\end{array}$ \\
\hline $\begin{array}{l}\text { Zheng and } \\
\text { Kruse }\end{array}$ & 2006 & General & $\begin{array}{l}\text { Population, } \\
\text { ecology }\end{array}$ & Red king crab & $\begin{array}{l}\text { Examines the correlations between geographic and seasonal } \\
\text { variability of crab stock, physical forcing, and groundfish } \\
\text { predation. Results suggest a mix of climate forcing and predation } \\
\text { in influencing crab recruitment. }\end{array}$ \\
\hline
\end{tabular}




\section{SEABIRDS, SHOREBIRDS, AND WATERFOWL}

This overview of information on seabirds, shorebirds, and waterfowl of the North Aleutian Basin and southeastern Bering Sea is based on a collection of about 150 reports, research papers, and web-published materials dated from 1996 to 2006. Some literature on the life history of species, the impacts of human activity on species, and migration for locales outside of the southeastern Bering Sea is included when the literature adds to the knowledge base for species occurring in the North Aleutian Basin.

Presentations at the Planning Meeting included overviews of (1) seabird and shorebird populations and distributions by Kathy Kuletz of the U.S. Fish and Wildlife Service (FWS) and (2) waterfowl populations and distributions by William Larned and Christian Dau of the FWS. The presentations, which can be found in the Planning Meeting report, summarize available information and information needs on these topics relevant to an impact assessment of oil and gas development.

Information on birds collected for this report includes general species descriptions; distribution, migration, and habitat; population size, population parameters, and dynamics; biotic relationships, including trophic and ecosystem relationships; impacts of human activities; and regulatory status, management, and conservation. Table 3 summarizes the content of recent publications, and full citations are provided in Section 7.3.

The life histories of birds have been described in detail in The Birds of North America Online, published by the Cornell Laboratory of Ornithology and the American Ornithological Union (http://bna.birds.cornell.edu/BNA/). The web articles are written by authorities in the life history and ecology of each species. The articles provide details on distribution, systematics, migration, habitat, food habits, behavior, breeding, demography and populations, conservation and management, and priorities for future research. Descriptions are not yet available for some Bering Sea species, such as the short-tailed albatross (Phoebastria albatrus). General life history information for the short-tailed shearwater (Puffinus tenuirostris), the short-tailed albatross, and certain other wide-ranging seabirds is not available at the same level of detail as for other species. While these species may not breed in the Bering Sea, the region is an important foraging and winter habitat. More study of the distribution and habits of these species may be needed.

Distribution, migration, and habitats of seabirds are monitored by the ADFG. In 1997, detailed maps were published that included seabird colonies on the Aleutian Islands, Alaska Peninsula, and Bristol Bay coastline. USGS and FWS have developed the North Pacific Pelagic Seabird Database, which includes observations on species and abundance from ship transects and other surveys. The database is an important source of information in assessing population trends, distribution, and impact assessment and is being used to produce a seabird atlas.

The North Aleutian Basin provides habitat for many seabirds. Surveys of seabirds have been accomplished with a variety of techniques, which makes statistical analysis of trends in population size and distribution difficult. While the winter range of eiders has been studied, the winter range of other species is incomplete or lacking. Several wide-ranging seabirds use the Bering Sea as wintering habitat, and resident and migrating Alaskan species are found in coastal 
lagoons and unfrozen areas of the sea. Determining the relationship between seabird distribution and potential oil and gas development in the North Aleutian Basin could be difficult.

The North Pacific Pelagic Seabird Database (which includes the North Aleutian Basin) contains estimates of the population sizes of nesting seabirds and of seabirds observed at sea. Surveys have been conducted on a seasonal and annual basis on waterfowl, including nesting, migrating, and wintering populations. These surveys focus on eiders and geese, but observations of other waterbirds are included. Survey information has been used to determine breeding status, productivity, and trends in populations. Long-term trends of seabird populations in the Aleutian Islands have been studied by examining paleoarcheological evidence. Oceanographic conditions and changes in prey base have been used to interpret these long-term trends. The genetic structure of selected species that could be affected by oil spills has been studied to determine the potential for recovery by recolonization.

Conservation of waterfowl, shorebirds, and seabirds has received regulatory attention due to the threatened or endangered status of their populations. The Steller's eider, spectacled eider (Somateria fischeri), and short-tailed albatross have received the most attention. Critical habitats have been designated, regulations governing longline fishing have been promulgated, and recovery plans pursuant to implementation of the Endangered Species Act (ESA) have been enacted. Environmental assessment of oil and gas development has resulted in the development of Biological Opinions for listed species. These opinions contain useful information on the ecology of the listed species.

Two species have been particularly well studied. The ecology of the Kittlitz's murrelet (Brachyramphus brevirostris) and the Steller's eider (Polysticta stelleri) have received special attention due at least in part to the threatened or endangered status of their populations. Studies of the Kittlitz's murrelet have focused on habitat requirements. Studies of the Steller's eider have looked at factors affecting migration, ecological relationships during the winter, and diet.

Studies of seabirds have described abundance, feeding behavior, and diet in relation to oceanographic features. Fronts and current patterns in Aleutian passes provide important feeding habitats for a variety of seabirds. Seabirds have been shown to be affected by recent ecosystem changes in the Bering Sea, and have been proposed as sensitive indicators of environmental change. Potential impacts to eiders from recent changes in clam populations in wintering locations have been studied. Population trends require continued study in order to provide a basis for assessment of future potential environmental impact.

The coastal lagoons of the Alaska Peninsula form a unique habitat for migrating shorebirds and waterfowl. A large proportion of western hemisphere shorebirds use these lagoons as staging areas during migration. Few recent studies of these lagoons and their birds were found. Since these habitats may be affected by North Aleutian Basin oil and gas development, further study of the ecology of these lagoons and their shorebirds may be warranted. 
Three important impacting factors on seabirds and shorebirds have been studied: (1) effects of oil spills on populations, (2) presence of inorganic and organic contaminants in seabirds, and (3) the effects of construction and development activities. Studies of oil effects have largely been conducted in Prince William Sound (as related to the Exxon Valdez oil spill), and studies of construction and development effects have focused on the effects of North Slope oil and gas development. Contaminant studies have been conducted on populations important in subsistence harvest, on Bering Sea islands and in the Yukon-Kuskokwim Delta.

One aspect of oil and gas development that has not been well studied is the effects of oil platforms on seabirds. Literature about these effects was found only for the North Atlantic and the Gulf of Mexico. The potential for bird collision at a proposed windfarm on St. Lawrence Island also has been assessed and the results of that assessment may be relevant. Collisions and attraction to lights are of particular concern. Because of the length of winter darkness and the importance of the region as habitat for wintering seabirds, studies of both collisions and attraction are needed. 
TABLE 3. Publications from 1996 to 2006 Related to Seabirds, Shorebirds, and Waterfowl of the North Aleutian Basin.

\begin{tabular}{|c|c|c|c|c|c|}
\hline Authors & Date & Location & Topic & Species & Document Content \\
\hline ADFG & $1997 \mathrm{a}$ & Bristol Bay & Distribution & Seabirds, waterfowl & $\begin{array}{l}\text { Map showing seabird colonies and waterfowl habitat } \\
\text { distribution of Togiak Bay and the Walrus Islands area. }\end{array}$ \\
\hline ADFG & $1997 b$ & Bristol Bay & Distribution & Seabirds, waterfowl & $\begin{array}{l}\text { Map showing seabird colonies and waterfowl habitat } \\
\text { distribution of Nushagak Bay area. }\end{array}$ \\
\hline ADFG & $1997 \mathrm{c}$ & Bristol Bay & Distribution & Seabirds, waterfowl & $\begin{array}{l}\text { Map showing seabird colonies and waterfowl distribution } \\
\text { of the Kvichak Bay area. }\end{array}$ \\
\hline $\mathrm{ADFG}$ & $1997 d$ & Bristol Bay & Distribution & Seabirds, waterfowl & $\begin{array}{l}\text { Map showing seabird colonies and waterfowl habitat } \\
\text { distribution of the Egigik Bay area. }\end{array}$ \\
\hline ADFG & $1997 \mathrm{e}$ & Bristol Bay & Distribution & Seabirds, waterfowl & $\begin{array}{l}\text { Map showing waterfowl habitat distribution of the } \\
\text { Ugashik Bay area. }\end{array}$ \\
\hline ADFG & $1997 f$ & Bristol Bay & Distribution & Seabirds, waterfowl & $\begin{array}{l}\text { Map showing waterfowl habitat distribution of the Cinder } \\
\text { River area. }\end{array}$ \\
\hline ADFG & $1997 \mathrm{~g}$ & Bristol Bay & Distribution & Seabirds, waterfowl & $\begin{array}{l}\text { Map showing waterfowl habitat distribution of the Port } \\
\text { Heiden area. }\end{array}$ \\
\hline $\mathrm{ADFG}$ & $1997 \mathrm{~h}$ & Bristol Bay & Distribution & Seabirds, waterfowl & $\begin{array}{l}\text { Map showing seabird colonies and waterfowl habitat } \\
\text { distribution of the Kujulik Bay area. }\end{array}$ \\
\hline ADNR & 2000 & $\begin{array}{l}\text { Bristol Bay, } \\
\text { Alaska } \\
\text { Peninsula }\end{array}$ & Distribution & Seabirds & $\begin{array}{l}\text { Map showing the location and size of seabird colonies for } \\
\text { Bristol Bay and the north and south Alaska Peninsula to } \\
\text { Port Moller and Ikofski. }\end{array}$ \\
\hline $\begin{array}{l}\text { Agler and } \\
\text { Kendall }\end{array}$ & 1997 & $\begin{array}{l}\text { Prince William } \\
\text { Sound }\end{array}$ & Impacts & Seabirds, waterfowl & $\begin{array}{l}\text { This report includes trends in marine bird populations } \\
\text { following the Exxon Valdez oil spill. }\end{array}$ \\
\hline Ainley et al. & 2002 & General & General & Common murre & $\begin{array}{l}\text { This chapter discusses the life history and ecology of the } \\
\text { common murre. }\end{array}$ \\
\hline $\begin{array}{l}\text { Alaska Maritime } \\
\text { National } \\
\text { Wildlife Refuge }\end{array}$ & 2006 & Alaska & $\begin{array}{l}\text { Breeding status, } \\
\text { population trends }\end{array}$ & Seabirds & $\begin{array}{l}\text { Website with links to yearly reports, "Breeding Status and } \\
\text { Population Trends of Seabirds in Alaska," from } 1996 \text { to } \\
2004 \text { (most recent). }\end{array}$ \\
\hline $\begin{array}{l}\text { Alaska Natural } \\
\text { Heritage } \\
\text { Program }\end{array}$ & 2005 & Alaska & General & Kittlitz's murrelet & $\begin{array}{l}\text { A description of the taxonomy, ecology, distribution and } \\
\text { abundance, existing protection, challenge, research and } \\
\text { inventory needs, conservation and management needs, } \\
\text { and a bibliography. }\end{array}$ \\
\hline
\end{tabular}


Table 3 (Cont.)

\begin{tabular}{|c|c|c|c|c|c|}
\hline Authors & Date & Location & Topic & Species & Document Content \\
\hline $\begin{array}{l}\text { Alaska } \\
\text { Shorebird } \\
\text { Working Group }\end{array}$ & 2000 & Alaska & Conservation & Shorebirds & $\begin{array}{l}\text { Describes conservation regions in Alaska, shorebird } \\
\text { species priorities, conservation issues, goals and } \\
\text { objectives, implementation, and coordination. Discusses } \\
\text { immediate priority projects for shorebirds in Alaska. } \\
\text { Identifies Western Hemisphere Shorebird Reserve } \\
\text { Network Sites in Alaska. }\end{array}$ \\
\hline ARRT & 2001 & Alaska & Distribution & Seabirds & $\begin{array}{l}\text { Presents excerpts from the Alaska Seabird Colony } \\
\text { Catalog in the form of detailed maps. }\end{array}$ \\
\hline BLM & 2005 & North Slope & Impacts & $\begin{array}{l}\text { Spectacled eider, Steller's } \\
\text { eider }\end{array}$ & $\begin{array}{l}\text { This appendix of the National Petroleum Reserve Alaska } \\
\text { EIS discusses the potential sources of impacts of } \\
\text { petroleum development on spectacled eider and Steller's } \\
\text { eider. }\end{array}$ \\
\hline Bustnes et al. & 2000 & Norway & Ecology & Steller's eider & $\begin{array}{l}\text { Paper reporting the diet of wintering Steller's eiders in } \\
\text { Norway. }\end{array}$ \\
\hline $\begin{array}{l}\text { Byrd and } \\
\text { Dragoo }\end{array}$ & 1997 & Alaska & Population & Seabirds & $\begin{array}{l}\text { Report presenting data on breeding success and } \\
\text { population trends of seabirds in Alaska in } 1996 .\end{array}$ \\
\hline Byrd et al. & 2005 & $\begin{array}{l}\text { Aleutian } \\
\text { Islands }\end{array}$ & Population & Seabirds & $\begin{array}{l}\text { This paper discusses seabird population trends and the } \\
\text { ecological factors, including predation, that affect } \\
\text { seabirds near island passes in the Aleutian Island chain. }\end{array}$ \\
\hline Causey et al. & 2005 & $\begin{array}{l}\text { Aleutian } \\
\text { Islands }\end{array}$ & Population & Seabirds & $\begin{array}{l}\text { Paleoarcheological data were examined to evaluate trends } \\
\text { in marine bird populations in the Aleutian Islands. } \\
\text { Although effects of human predation could be detected on } \\
\text { a local scale, evidence suggests that local oceanography } \\
\text { and changes in prey base in the past had a significant } \\
\text { effect on abundance of seabirds. }\end{array}$ \\
\hline $\begin{array}{l}\text { Center for } \\
\text { Biological } \\
\text { Diversity et al. }\end{array}$ & 2001 & General & Regulation & Kittlitz's murrelet & $\begin{array}{l}\text { This petition to add Kittlitz's murrelet to the endangered } \\
\text { species list discusses potential threats to the species. }\end{array}$ \\
\hline $\begin{array}{l}\text { Christopher } \\
\text { et al. }\end{array}$ & 2002 & $\begin{array}{l}\text { Bering Sea, } \\
\text { Gulf of Alaska }\end{array}$ & Impacts & Common murre & $\begin{array}{l}\text { Reports on measured mercury concentrations in common } \\
\text { murres from the Bering Sea and Gulf of Alaska. }\end{array}$ \\
\hline
\end{tabular}


Table 3 (Cont.)

\begin{tabular}{|c|c|c|c|c|c|}
\hline Authors & Date & Location & Topic & Species & Document Content \\
\hline $\begin{array}{l}\text { Circumpolar } \\
\text { Seabird } \\
\text { Working Group }\end{array}$ & 1997 & Worldwide & $\begin{array}{l}\text { Distribution, } \\
\text { conservation }\end{array}$ & Eiders & $\begin{array}{l}\text { Discusses the worldwide range and abundance of eiders, } \\
\text { utilization of eiders, and management, conservation, and } \\
\text { population trends. Identifies management issues and } \\
\text { actions, and develops management guidelines. }\end{array}$ \\
\hline Dau and Mallek & 2006 & $\begin{array}{l}\text { Southwestern } \\
\text { Alaska }\end{array}$ & Populations & $\begin{array}{l}\text { Emperor goose, Brant, } \\
\text { Steller's eider, other } \\
\text { waterbirds }\end{array}$ & $\begin{array}{l}\text { Overflights were used to survey populations of emperor } \\
\text { geese and other waterbirds from Kokechek Bay to } \\
\text { Unimak Island, including both sides of the peninsula, } \\
\text { during April and May 2004. Brant and Steller's eider } \\
\text { were among the species counted. }\end{array}$ \\
\hline Dau et al. & 2000 & $\begin{array}{l}\text { Alaska } \\
\text { Peninsula }\end{array}$ & Distribution & Steller's eider & $\begin{array}{l}\text { Reports the results of banding and recovering molting } \\
\text { Steller's eiders along the lower Alaska peninsula. }\end{array}$ \\
\hline Day and Nigro & 2000 & $\begin{array}{l}\text { Prince William } \\
\text { Sound }\end{array}$ & Ecology & Marbled murrelet & $\begin{array}{l}\text { Discusses feeding ecology of marbled murrelets in Prince } \\
\text { William Sound. }\end{array}$ \\
\hline Day and Nigro & 2003 & $\begin{array}{l}\text { Prince William } \\
\text { Sound }\end{array}$ & Ecology & Kittlitz's murrelet & $\begin{array}{l}\text { Evaluates Kittlitz's murrelet on Prince William Sound } \\
\text { reproductive problems. }\end{array}$ \\
\hline Day et al. & $1997 \mathrm{a}$ & $\begin{array}{l}\text { Kenai } \\
\text { Peninsula }\end{array}$ & Impacts & General & $\begin{array}{l}\text { Reports on the effect of the Exxon Valdez oil spill on bird } \\
\text { habitat use along the Kenai Peninsula. }\end{array}$ \\
\hline Day et al. & $1997 b$ & $\begin{array}{l}\text { Prince William } \\
\text { Sound }\end{array}$ & Impacts & General & $\begin{array}{l}\text { Reports on the effect of the Exxon Valdez oil spill on bird } \\
\text { habitat use in Prince William Sound. }\end{array}$ \\
\hline Day et al & 1999 & General & General & Kittlitz's murrelet & $\begin{array}{l}\text { This chapter discusses the life history and ecology of } \\
\text { Kittlitz's murrelet. }\end{array}$ \\
\hline Day et al. & 2000 & $\begin{array}{l}\text { Prince William } \\
\text { Sound }\end{array}$ & Ecology & Kittlitz's murrelet & $\begin{array}{l}\text { Describes at-sea habitats of Kittlitz's murrelets in Prince } \\
\text { William Sound. }\end{array}$ \\
\hline Day et al. & $2003 a$ & $\begin{array}{l}\text { Prince William } \\
\text { Sound }\end{array}$ & Ecology & $\begin{array}{l}\text { Kittlitz's murrelet, marbled } \\
\text { murrelet }\end{array}$ & $\begin{array}{l}\text { Examines the habitat use and niche overlap between } \\
\text { Kittlitz's murrelet and marbled murrelet in nearshore } \\
\text { waters of Prince William Sound. Discusses the } \\
\text { significance of habitat differences as related to } \\
\text { morphological differences. }\end{array}$ \\
\hline Day et al. & $2003 b$ & $\begin{array}{l}\text { St. Lawrence } \\
\text { Island, Bering } \\
\text { Sea }\end{array}$ & Impacts & Eiders, general birds & $\begin{array}{l}\text { Assesses the potential collision potential of eiders and } \\
\text { other birds near a proposed wind farm at St. Lawrence } \\
\text { Island in the Bering Sea. }\end{array}$ \\
\hline
\end{tabular}


Table 3 (Cont.)

\begin{tabular}{|c|c|c|c|c|c|}
\hline Authors & Date & Location & Topic & Species & Document Content \\
\hline Day et al. & $2005 a$ & Beaufort Sea & Impacts & Eiders, general & $\begin{array}{l}\text { Reports the results of studies of migration and collision } \\
\text { avoidance of eiders and other birds at Northstar Island in } \\
\text { 2001-2004. }\end{array}$ \\
\hline Day et al. & $2005 b$ & North Slope & Ecology & Eiders & $\begin{array}{l}\text { This paper presents observations of factors affecting } \\
\text { migration of eiders, including weather. The height of } \\
\text { migrating eiders was determined. }\end{array}$ \\
\hline DOC & 1997 & Alaska & Conservation & Seabirds & $\begin{array}{l}\text { Establishes management measures for the fisheries of the } \\
\text { Exclusive Economic Zone to reduce seabird bycatch in } \\
\text { hook-and-line groundfish fisheries. }\end{array}$ \\
\hline DOC & 1998 & Alaska & Conservation & Seabirds & $\begin{array}{l}\text { Establishes management measures to reduce seabird } \\
\text { bycatch in halibut fisheries. }\end{array}$ \\
\hline DOD & 1999 & Beaufort Sea & Impacts & General & $\begin{array}{l}\text { Environmental impact statement addressing impacts of } \\
\text { the Northstar project. }\end{array}$ \\
\hline DOI & 1997 & General & Conservation & Steller's eider & $\begin{array}{l}\text { Final rule for establishing the threatened status for the } \\
\text { Alaska breeding population of the Steller's eider. }\end{array}$ \\
\hline DOI & 2000 & General & Conservation & Spectacled eider & $\begin{array}{l}\text { Identifies and supports proposed critical habitat for the } \\
\text { spectacled eider. }\end{array}$ \\
\hline DOI & $2001 \mathrm{a}$ & General & Conservation & Spectacled eider & $\begin{array}{l}\text { Final determination of designated critical habitat for the } \\
\text { spectacled eider. }\end{array}$ \\
\hline DOI & $2001 b$ & General & Conservation & Steller's eider & $\begin{array}{l}\text { Final determination of designated critical habitat for the } \\
\text { Alaska-breeding population of the Steller's eider. }\end{array}$ \\
\hline DOI & $2001 \mathrm{c}$ & General & Conservation & Aleutian Canada goose & $\begin{array}{l}\text { Final rule to remove the Aleutian Canada goose from the } \\
\text { federal list of endangered and threatened wildlife. }\end{array}$ \\
\hline DOI & 2003 & General & Conservation & Steller's eider & $\begin{array}{l}\text { Announces the availability of the recovery plan for the } \\
\text { Alaska breeding population of the Steller's eider. }\end{array}$ \\
\hline DOI & $2005 a$ & General & Impacts & Seabirds & $\begin{array}{l}\text { This website describes the Seabird Tissue Archival and } \\
\text { Monitoring Project. }\end{array}$ \\
\hline DOI & $2005 b$ & General & Ecology & General & $\begin{array}{l}\text { This website provides access to the FWS's Wetlands } \\
\text { Digital Data. }\end{array}$ \\
\hline Dragoo et al. & 2000 & General & $\begin{array}{l}\text { Population, } \\
\text { ecology }\end{array}$ & Seabirds & $\begin{array}{l}\text { This report provides information on breeding status and } \\
\text { population trends of seabirds in Alaska in } 1999 .\end{array}$ \\
\hline
\end{tabular}


Table 3 (Cont.)

\begin{tabular}{|c|c|c|c|c|c|}
\hline Authors & Date & Location & Topic & Species & Document Content \\
\hline Dragoo et al. & 2003 & General & $\begin{array}{l}\text { Population, } \\
\text { ecology }\end{array}$ & Seabirds & $\begin{array}{l}\text { This report provides information on the breeding status, } \\
\text { population trends, and diets of seabirds in } 2001 \text {. }\end{array}$ \\
\hline Dragoo et al. & 2004 & General & $\begin{array}{l}\text { Population, } \\
\text { ecology }\end{array}$ & Seabirds & $\begin{array}{l}\text { This report provides information on the breeding status, } \\
\text { population trends, and diets of seabirds in } 2002 \text {. }\end{array}$ \\
\hline Drew and Piatt & $2005 a$ & North Pacific & $\begin{array}{l}\text { Population, } \\
\text { distribution }\end{array}$ & Seabirds & $\begin{array}{l}\text { Report describing the North Pacific Pelagic Seabird } \\
\text { Database. }\end{array}$ \\
\hline Drew and Piatt & $2005 b$ & North Pacific & Distribution & Seabirds & $\begin{array}{l}\text { This presentation describes the creation of the North } \\
\text { Pacific Pelagic Seabird Database and the studies that have } \\
\text { used the database. }\end{array}$ \\
\hline Esler et al. & 2000 & $\begin{array}{l}\text { Prince William } \\
\text { Sound }\end{array}$ & Impacts & Harlequin duck & $\begin{array}{l}\text { This paper compares winter survival of adult harlequin } \\
\text { ducks in oiled and unoiled areas in order to interpret } \\
\text { impacts of the Exxon Valdez oil spill. }\end{array}$ \\
\hline Esler et al. & 2002 & $\begin{array}{l}\text { Prince William } \\
\text { Sound }\end{array}$ & Impacts & Harlequin duck & $\begin{array}{l}\text { This paper discusses recovery of harlequin duck } \\
\text { populations after the Exxon Valdez oil spill. Constraints to } \\
\text { recovery are discussed. }\end{array}$ \\
\hline Estes et al. & 1997 & $\begin{array}{l}\text { Aleutian } \\
\text { Islands }\end{array}$ & Impacts & Bald eagles & $\begin{array}{l}\text { This paper reports data on organochlorines in bald eagles } \\
\text { from the Aleutian Archipelago. }\end{array}$ \\
\hline Flint and Fowler & 1998 & St. Paul Island & Impacts & Seabirds & $\begin{array}{l}\text { This paper discusses experiments to assess the influence } \\
\text { of wind on recovery of oiled seabirds. }\end{array}$ \\
\hline Flint and Miles & 2002 & $\begin{array}{l}\text { Aleutian } \\
\text { Islands, Alaska } \\
\text { Peninsula }\end{array}$ & Impacts & Steller's eider & $\begin{array}{l}\text { This report discusses the effects of boat harbors, fish } \\
\text { processing, and organic contamination on wintering } \\
\text { Steller's eiders. }\end{array}$ \\
\hline Flint et al. & 1997 & Alaska & Impacts & $\begin{array}{l}\text { Spectacled eider, diving } \\
\text { ducks }\end{array}$ & $\begin{array}{l}\text { Discusses lead exposure of diving ducks in western } \\
\text { Alaska. }\end{array}$ \\
\hline Flint et al. & 1998 & General & Population & Northern pintail & $\begin{array}{l}\text { Reports modeling of the productivity and population } \\
\text { growth rate of the northern pintail. }\end{array}$ \\
\hline Flint et al. & 1999 & $\begin{array}{l}\text { St. Paul Island, } \\
\text { Bering Sea }\end{array}$ & Impacts & Seabirds & $\begin{array}{l}\text { Presents modeling of bird mortality associated with the } \\
\text { M/V Citrus oil spill off St. Paul Island. }\end{array}$ \\
\hline Flint et al. & 2000 & $\begin{array}{l}\text { Alaska } \\
\text { Peninsula }\end{array}$ & Population & Steller's eider & $\begin{array}{l}\text { Reports annual survival and site fidelity of Steller's } \\
\text { eiders. }\end{array}$ \\
\hline
\end{tabular}


Table 3 (Cont.)

\begin{tabular}{|c|c|c|c|c|c|}
\hline Authors & Date & Location & Topic & Species & Document Content \\
\hline Flint et al. & 2004 & General & Ecology & Long-tailed duck & $\begin{array}{l}\text { This paper discusses movements of flightless long-tailed } \\
\text { ducks during wing molt. }\end{array}$ \\
\hline Fowler and Flint & 1997 & $\begin{array}{l}\text { St. Paul Island, } \\
\text { Bering Sea }\end{array}$ & Impacts & King eider & $\begin{array}{l}\text { The persistence of oiled king eider carcasses following an } \\
\text { oil spill was modeled to help determine mortality rates. }\end{array}$ \\
\hline Fredrickson & 2001 & General & General & Steller's eider & $\begin{array}{l}\text { This chapter discusses life history and ecology of Steller's } \\
\text { eider. }\end{array}$ \\
\hline FWS & $1996 a$ & Alaska & Population & Seabirds & A catalog of Alaska seabird colonies. \\
\hline FWS & $1996 b$ & General & Conservation & Spectacled eider & Recovery plan for the spectacled eider. \\
\hline FWS & $1999 a$ & $\begin{array}{l}\text { Bering Sea, } \\
\text { Aleutian } \\
\text { Islands }\end{array}$ & Conservation & Short-tailed albatross & $\begin{array}{l}\text { Biological Opinion on the effects of the Bering } \\
\text { Sea/Aleutian Islands fishery on the short-tailed albatross. }\end{array}$ \\
\hline FWS & $1999 b$ & Alaska & Population & Sea ducks & $\begin{array}{l}\text { This report discusses population status and population } \\
\text { trends in sea ducks in Alaska. }\end{array}$ \\
\hline FWS & 2000 & $\begin{array}{l}\text { Alaska } \\
\text { Peninsula }\end{array}$ & Impacts & Steller's eider & $\begin{array}{l}\text { Biological Opinion on the effects of harbor construction } \\
\text { on the Steller's eider. }\end{array}$ \\
\hline FWS & 2001 & Alaska & General & Short-tailed albatross & This fact sheet describes the short-tailed albatross. \\
\hline FWS & 2002 & Alaska & Conservation & Steller's eider & Recovery plan for the Steller's eider. \\
\hline FWS & $2004 a$ & $\begin{array}{l}\text { Southwest } \\
\text { Alaska }\end{array}$ & Population & Steller's eider & $\begin{array}{l}\text { This report presents the Steller's eider spring migration } \\
\text { survey in southwest Alaska. }\end{array}$ \\
\hline FWS & $2004 b$ & $\begin{array}{l}\text { Alaska } \\
\text { Peninsula, } \\
\text { Bristol Bay, } \\
\text { Bering Sea }\end{array}$ & Conservation & Steller's eider & Critical habitat map for the Steller's eider. \\
\hline $\begin{array}{l}\text { Gaston and } \\
\text { Hipfner }\end{array}$ & 2000 & General & General & Thick-billed murre & $\begin{array}{l}\text { This chapter discusses the life history and ecology of the } \\
\text { thick-billed murre. }\end{array}$ \\
\hline Gilchrist & 2001 & General & General & Thick-billed murre & $\begin{array}{l}\text { This chapter discusses the life history and ecology of the } \\
\text { glaucous gull. }\end{array}$ \\
\hline Gill & 2004 & Alaska & General & Shorebirds & $\begin{array}{l}\text { This report contains summaries of studies on Alaska } \\
\text { shorebirds ongoing in } 2003 \text {. }\end{array}$ \\
\hline $\begin{array}{l}\text { Gill and } \\
\text { McCaffery }\end{array}$ & 1999 & Alaska & Population & Bar-tailed godwits & $\begin{array}{l}\text { This paper provides population estimates of bar-tailed } \\
\text { godwits based on observations from the staging grounds. }\end{array}$ \\
\hline
\end{tabular}


Table 3 (Cont.)

\begin{tabular}{|c|c|c|c|c|c|}
\hline Authors & Date & Location & Topic & Species & Document Content \\
\hline Gill and Senner & 1996 & Alaska & Conservation & Shorebirds & $\begin{array}{l}\text { This paper discusses the importance of Alaska to western } \\
\text { hemisphere shorebirds. }\end{array}$ \\
\hline Golet et al. & 2002 & $\begin{array}{l}\text { Prince William } \\
\text { Sound }\end{array}$ & Impacts & Pigeon guillemot & $\begin{array}{l}\text { This paper discusses the long-term and indirect effects of } \\
\text { the Exxon Valdez oil spill on pigeon guillemots. }\end{array}$ \\
\hline Goudie et al. & 2000 & General & General & Common eider & $\begin{array}{l}\text { This book chapter describes the life history and ecology } \\
\text { of the common eider. }\end{array}$ \\
\hline Grand et al. & 1998 & Alaska & Impacts & Spectacled eider & $\begin{array}{l}\text { This paper discusses the effects of lead poisoning on } \\
\text { spectacled eider survival rates. }\end{array}$ \\
\hline Grand et al. & 2002 & $\begin{array}{l}\text { Yukon-Kusk- } \\
\text { okwim Delta }\end{array}$ & Impacts & $\begin{array}{l}\text { Spectacled eider, common } \\
\text { eider }\end{array}$ & $\begin{array}{l}\text { This paper presents concentrations of trace elements in } \\
\text { the eggs and blood of spectacled and common eiders. }\end{array}$ \\
\hline Guillemette & 1998 & $\begin{array}{l}\text { Gulf of St. } \\
\text { Lawrence }\end{array}$ & Ecology & Common eider & $\begin{array}{l}\text { This paper discusses aspects of feeding, diving, and } \\
\text { digestion of common eiders feeding on blue mussel beds } \\
\text { in the winter. }\end{array}$ \\
\hline Guillemette & 2001 & $\begin{array}{l}\text { Gulf of St. } \\
\text { Lawrence }\end{array}$ & Ecology & Common eider & $\begin{array}{l}\text { This paper discusses spring feeding rates of common } \\
\text { eiders in the Gulf of St. Lawrence. }\end{array}$ \\
\hline Handel and Gill & 2000 & Alaska & Ecology & Black turnstone & This paper discusses monogamy in the black turnstone. \\
\hline Handel and Gill & 2001 & General & General & Black turnstone & $\begin{array}{l}\text { This chapter describes the life history and ecology of the } \\
\text { black turnstone. }\end{array}$ \\
\hline Harding et al. & 2005 & Alaska, Russia & Population & Horned puffin & $\begin{array}{l}\text { This paper discusses census methods for crevice-nesting } \\
\text { puffins. }\end{array}$ \\
\hline Hatch et al. & 1996 & $\begin{array}{l}\text { Bering Sea, } \\
\text { Chukchi Sea, } \\
\text { Gulf of Alaska }\end{array}$ & Population & $\begin{array}{l}\text { Common murres, thick- } \\
\text { billed murres, tufted puffins }\end{array}$ & $\begin{array}{l}\text { This report provides estimates of seasonal movements and } \\
\text { habitat use by common murres and tufted puffins. }\end{array}$ \\
\hline Hatch et al. & 2000 & $\begin{array}{l}\text { Bering Sea, } \\
\text { Chukchi Sea, } \\
\text { Gulf of Alaska }\end{array}$ & Population & $\begin{array}{l}\text { Common murres, thick- } \\
\text { billed murres, tufted puffins }\end{array}$ & $\begin{array}{l}\text { This report provides estimates of seasonal movements and } \\
\text { habitat use by common murres, thick-billed murres, and } \\
\text { tufted puffins. }\end{array}$ \\
\hline Hobson & 1997 & General & General & Pelagic cormorant & $\begin{array}{l}\text { This book chapter discusses life history and ecology of } \\
\text { the pelagic cormorant. }\end{array}$ \\
\hline Hodges et al. & 1996 & Alaska & Population & Seabirds & $\begin{array}{l}\text { Reports the results of aerial surveys of seabirds in } 1957- \\
1994 .\end{array}$ \\
\hline
\end{tabular}


Table 3 (Cont.)

\begin{tabular}{|c|c|c|c|c|c|}
\hline Authors & Date & Location & Topic & Species & Document Content \\
\hline Hunt et al. & 2001 & North Pacific & Ecology & Seabirds & $\begin{array}{l}\text { This report discusses consumption of prey by marine } \\
\text { birds in the subarctic North Pacific Ocean. It contains } \\
\text { aggregate estimates by region of prey class, consumption } \\
\text { rates, biomass, and energy transfer. The report also } \\
\text { contains estimates of the populations of major groups of } \\
\text { seabirds. }\end{array}$ \\
\hline Hunt et al. & 2005 & Gulf of Alaska & Ecology & Seabirds & $\begin{array}{l}\text { This paper presents data on prey consumption and energy } \\
\text { transfer by seabirds (shearwaters, murres, puffins, } \\
\text { murrelets, auklets, and sea ducks) in the Gulf of Alaska. }\end{array}$ \\
\hline Irons et al. & 2000 & $\begin{array}{l}\text { Prince William } \\
\text { Sound }\end{array}$ & Impacts & Marine birds & $\begin{array}{l}\text { This paper compares populations of a variety of seabirds } \\
\text { before and after the Exxon Valdez oil spill. Data are } \\
\text { interpreted with respect to life history parameters. }\end{array}$ \\
\hline Jahncke et al. & 2005 & $\begin{array}{l}\text { Aleutian } \\
\text { Islands }\end{array}$ & $\begin{array}{l}\text { Distribution, } \\
\text { ecology }\end{array}$ & Seabirds & $\begin{array}{l}\text { This paper presents the differences in seabird abundance, } \\
\text { distribution, and diet between the eastern and central } \\
\text { Aleutian Islands. Oceanographic factors and diet are } \\
\text { evaluated. }\end{array}$ \\
\hline Jones et al. & 2001 & General & General & Parakeet auklet & $\begin{array}{l}\text { This book chapter discusses the life history and ecology } \\
\text { of the parakeet auklet. }\end{array}$ \\
\hline Kitaysky et al. & 2006 & North Pacific & Ecology & Red-legged kittiwake & $\begin{array}{l}\text { This paper discusses the effects of lipid-poor diets on } \\
\text { condition of juvenile red-legged kittiwakes. The authors } \\
\text { conclude lipid-poor diets may result in population } \\
\text { declines. }\end{array}$ \\
\hline Kucklick et al. & 2002 & $\begin{array}{l}\text { Bering Sea, } \\
\text { Gulf of Alaska }\end{array}$ & Impacts & $\begin{array}{l}\text { Common murre, thick-billed } \\
\text { murre }\end{array}$ & $\begin{array}{l}\text { This presentation discusses the presence of persistent } \\
\text { organic pollutants in murre eggs. }\end{array}$ \\
\hline Kuletz & 2004 & Alaska & Population & Kittlitz's murrelet & $\begin{array}{l}\text { This paper discusses the relationship between glaciation } \\
\text { and Kittlitz's murrelet. }\end{array}$ \\
\hline Kuletz et al. & 2003 & $\begin{array}{l}\text { Prince William } \\
\text { Sound }\end{array}$ & Population & Kittlitz's murrelet & $\begin{array}{l}\text { This paper discusses the relationship between glaciation } \\
\text { in Prince William Sound and Kittlitz's murrelet. }\end{array}$ \\
\hline Lacroix et al. & 2003 & Beaufort Sea & Impacts & Long-tailed duck & $\begin{array}{l}\text { This paper reports the results of studies of the effects of } \\
\text { underwater seismic surveys on molting male long-tailed } \\
\text { ducks. }\end{array}$ \\
\hline
\end{tabular}


Table 3 (Cont.)

\begin{tabular}{|c|c|c|c|c|c|}
\hline Authors & Date & Location & Topic & Species & Document Content \\
\hline Ladd et al. & 2005 & $\begin{array}{l}\text { Aleutian } \\
\text { Islands }\end{array}$ & Distribution & Seabirds & $\begin{array}{l}\text { This paper discusses the foraging behavior of different } \\
\text { seabirds at the convergence zones and fronts between } \\
\text { water masses in Aleutian passes. }\end{array}$ \\
\hline Lance et al. & 2001 & $\begin{array}{l}\text { Prince William } \\
\text { Sound }\end{array}$ & Population & General & $\begin{array}{l}\text { This paper investigates evidence of population recovery } \\
\text { of a wide variety of affected species oiled by the Exxon } \\
\text { Valdez oil spill. }\end{array}$ \\
\hline Lanctot et al. & 1999 & $\begin{array}{l}\text { Prince William } \\
\text { Sound }\end{array}$ & Population & Harlequin duck & $\begin{array}{l}\text { This study looks at genetic differences in harlequin duck } \\
\text { populations to evaluate the potential for migration to } \\
\text { repopulate depleted populations. }\end{array}$ \\
\hline Larned & 1998 & $\begin{array}{l}\text { Western } \\
\text { Alaska }\end{array}$ & Population & King eider & $\begin{array}{l}\text { This report presents the results of aerial surveys of king } \\
\text { eider molting areas in western Alaska. }\end{array}$ \\
\hline Larned & $2000 \mathrm{a}$ & $\begin{array}{l}\text { Southwest } \\
\text { Alaska }\end{array}$ & Population & Steller's eider, seabirds & $\begin{array}{l}\text { This report presents the results of aerial surveys of } \\
\text { Steller's eiders and other seabirds. }\end{array}$ \\
\hline Larned & $2000 b$ & $\begin{array}{l}\text { Southwest } \\
\text { Alaska }\end{array}$ & Population & Steller's eider & $\begin{array}{l}\text { This report presents the results of } 2000 \text { spring migration } \\
\text { surveys for the Steller's eider. }\end{array}$ \\
\hline Larned & 2002 & $\begin{array}{l}\text { Southwest } \\
\text { Alaska }\end{array}$ & Population & Steller's eider & $\begin{array}{l}\text { This report presents the result of } 2002 \text { spring migration } \\
\text { surveys for the Steller's eider. }\end{array}$ \\
\hline Larned & 2003 & Bering Sea & Population & Spectacled eider & $\begin{array}{l}\text { This report presents the results of late wintering surveys } \\
\text { of spectacled eiders in the Bering Sea in 1996-1997. }\end{array}$ \\
\hline Larned & 2004 & $\begin{array}{l}\text { Southwest } \\
\text { Alaska }\end{array}$ & Population & Steller's eider & $\begin{array}{l}\text { This report presents the result of } 2004 \text { spring migration } \\
\text { surveys for the Steller's eider. }\end{array}$ \\
\hline Larned & 2005 & $\begin{array}{l}\text { Southwest } \\
\text { Alaska }\end{array}$ & Population & Steller's eider & $\begin{array}{l}\text { This report presents the result of } 2005 \text { spring migration } \\
\text { surveys for the Steller's eider. }\end{array}$ \\
\hline $\begin{array}{l}\text { Larned and } \\
\text { Tiplady }\end{array}$ & 1997 & Bering Sea & Population & Spectacled eider & $\begin{array}{l}\text { This report presents the results of late wintering surveys } \\
\text { of spectacled eiders in the Bering Sea in 1996-1997. }\end{array}$ \\
\hline $\begin{array}{l}\text { Larned and } \\
\text { Tiplady }\end{array}$ & 1999 & Bering Sea & Population & Spectacled eider & $\begin{array}{l}\text { This report presents the results of late wintering surveys } \\
\text { of spectacled eiders in the Bering Sea in } 1998 .\end{array}$ \\
\hline $\begin{array}{l}\text { Laubhan and } \\
\text { Metzner }\end{array}$ & 1999 & $\begin{array}{l}\text { Alaska } \\
\text { Peninsula }\end{array}$ & Population & Steller's eider & $\begin{array}{l}\text { This paper reports the results of surveys of wintering } \\
\text { Steller's eiders in Izembeck Lagoon and Cold Bay }\end{array}$ \\
\hline Litzow et al. & 2002 & Gulf of Alaska & Ecology & Pigeon guillemot & $\begin{array}{l}\text { This paper presents data on survival of pigeon guillemot } \\
\text { chicks in areas of low-lipid food and high-lipid food. }\end{array}$ \\
\hline
\end{tabular}


Table 3 (Cont.)

\begin{tabular}{|c|c|c|c|c|c|}
\hline Authors & Date & Location & Topic & Species & Document Content \\
\hline Lovvorn et al. & 2000 & Bering Sea & Ecology & Spectacled eider & $\begin{array}{l}\text { This study describes the development of an empirically } \\
\text { based computer model of the foraging energetics of the } \\
\text { spectacled eider that winters southwest of the St. } \\
\text { Lawrence Island polynya in the Bering Sea. }\end{array}$ \\
\hline Lovvorn et al. & 2003 & Bering Sea & Ecology & Spectacled eider & $\begin{array}{l}\text { This paper presents the results of studies of diet and body } \\
\text { condition of wintering spectacled eiders. Diet was } \\
\text { investigated by examination of stomach contents. }\end{array}$ \\
\hline Mallek and Dau & 2004 & $\begin{array}{l}\text { Southwestern } \\
\text { Alaska }\end{array}$ & Population & Emperor goose, seabirds & $\begin{array}{l}\text { This report presents the results of aerial surveys of } \\
\text { Emperor geese and other seabirds in southwestern Alaska } \\
\text { during fall } 2002 \text {. }\end{array}$ \\
\hline Mallek and Dau & 2005 & $\begin{array}{l}\text { Southwestern } \\
\text { Alaska }\end{array}$ & Population & Emperor goose, seabirds & $\begin{array}{l}\text { This report presents the results of aerial surveys of } \\
\text { Emperor geese and other seabirds in southwestern Alaska } \\
\text { during fall } 2005 \text {. }\end{array}$ \\
\hline $\begin{array}{l}\text { McCaffery and } \\
\text { Gill }\end{array}$ & 2001 & General & General & Bar-tailed godwit & $\begin{array}{l}\text { This book chapter presents the life history and ecology of } \\
\text { the bar-tailed godwit. }\end{array}$ \\
\hline Meehan et al. & 1999 & Alaska & Ecology & Seabirds & $\begin{array}{l}\text { This paper discusses the importance of seabird } \\
\text { populations as indicators of the ecosystem effects of } \\
\text { climate change and environmental effects of } \\
\text { development. }\end{array}$ \\
\hline Melvin et al. & 2006 & Alaska & Distribution & Seabirds & $\begin{array}{l}\text { This report discusses observations of seabirds obtained } \\
\text { during stock assessments of Pacific halibut and sablefish. } \\
\text { Species composition by region is presented. Implications } \\
\text { for longline fishery impacts on seabirds are discussed. }\end{array}$ \\
\hline Murphy et al. & 1997 & $\begin{array}{l}\text { Prince William } \\
\text { sound }\end{array}$ & Impacts & $\begin{array}{l}\text { Seabirds, shorebirds, } \\
\text { waterfowl }\end{array}$ & $\begin{array}{l}\text { This paper discusses the effects of the Exxon Valdez oil } \\
\text { spill on birds based on pre- and post-spill surveys. }\end{array}$ \\
\hline Pearce et al. & 2005 & Worldwide & Population & Steller's eider & $\begin{array}{l}\text { This paper presents studies of genetic differentiation } \\
\text { among Steller's eider populations in order to facilitate } \\
\text { conservation. }\end{array}$ \\
\hline $\begin{array}{l}\text { Petersen and } \\
\text { Douglas }\end{array}$ & 2004 & Bering Sea & Ecology & Spectacled eider & $\begin{array}{l}\text { This study describes the environmental characteristics of } \\
\text { wintering areas for spectacled eiders and discusses the } \\
\text { relationship of these characteristics to population biology. }\end{array}$ \\
\hline
\end{tabular}


Table 3 (Cont.)

\begin{tabular}{|c|c|c|c|c|c|}
\hline Authors & Date & Location & Topic & Species & Document Content \\
\hline $\begin{array}{l}\text { Petersen and } \\
\text { Flint }\end{array}$ & 2002 & $\begin{array}{l}\text { Bering Sea, } \\
\text { Beaufort Sea }\end{array}$ & Population & Common eider & $\begin{array}{l}\text { This paper describes the degree of isolation of Bering Sea } \\
\text { and Beaufort Sea populations of the common eider. }\end{array}$ \\
\hline Petersen et al. & 1998 & Bering Sea & Ecology & Spectacled eider & This paper presents data on the diet of spectacled eiders. \\
\hline Petersen et al. & 1999 & $\begin{array}{l}\text { Bering Sea, } \\
\text { Arctic Alaska, } \\
\text { and Russia }\end{array}$ & Population & Spectacled eider & $\begin{array}{l}\text { This paper reviews data and observations on spectacled } \\
\text { eiders to identify seasonal habitats, including wintering } \\
\text { grounds. }\end{array}$ \\
\hline Piatt and Drew & 2004 & $\begin{array}{l}\text { Aleutian } \\
\text { Islands }\end{array}$ & Population & Seabirds & $\begin{array}{l}\text { This paper uses the North Pacific Pelagic Seabird } \\
\text { Database to estimate the abundance of seabirds within } \\
100 \mathrm{~km} \text { of the Selendang Ayu grounding on Unalaska } \\
\text { Island. }\end{array}$ \\
\hline Piatt and Ford & $2000 \mathrm{a}$ & Alaska & Distribution & Seabirds & $\begin{array}{l}\text { This report describes a computerized pelagic seabird atlas } \\
\text { for Alaska. }\end{array}$ \\
\hline Piatt and Ford & $2000 \mathrm{~b}$ & Alaska & Population & Seabirds & $\begin{array}{l}\text { This report describes the use of a pelagic seabird atlas for } \\
\text { monitoring seabird populations in areas of potential } \\
\text { development. }\end{array}$ \\
\hline $\begin{array}{l}\text { Piatt and } \\
\text { Kitaysky }\end{array}$ & 2002 & General & General & Horned puffin & $\begin{array}{l}\text { This chapter describes the life history and ecology of the } \\
\text { horned puffin. }\end{array}$ \\
\hline $\begin{array}{l}\text { Piatt and } \\
\text { Springer }\end{array}$ & 2004 & Bering Sea & Ecology & Seabirds & $\begin{array}{l}\text { This paper discusses the factors affecting the } \\
\text { biogeography of seabirds in the Bering Sea. }\end{array}$ \\
\hline Piatt et al. & 2006 & Alaska & $\begin{array}{l}\text { Distribution, } \\
\text { population }\end{array}$ & Seabirds & $\begin{array}{l}\text { This atlas was developed from the North Pacific Pelagic } \\
\text { Seabird Database. It illustrates data on abundance and } \\
\text { distribution of } 31 \text { species/groups of seabirds. }\end{array}$ \\
\hline $\begin{array}{l}\text { Richman and } \\
\text { Lovvorn }\end{array}$ & 2003 & Bering Sea & Ecology & Spectacled eider & $\begin{array}{l}\text { This paper discusses the characteristics of clam species } \\
\text { that affect the energetics of spectacled eiders. }\end{array}$ \\
\hline $\begin{array}{l}\text { Robertson and } \\
\text { Savard }\end{array}$ & 2002 & General & General & Long-tailed duck & $\begin{array}{l}\text { This book chapter discusses the life history and ecology } \\
\text { of the long-tailed duck. }\end{array}$ \\
\hline Russell & 2005 & $\begin{array}{l}\text { Gulf of } \\
\text { Mexico }\end{array}$ & Impacts & Migrating birds & $\begin{array}{l}\text { This report gives detailed observations of migrating birds } \\
\text { on offshore gas and oil platforms in the northern Gulf of } \\
\text { Mexico. }\end{array}$ \\
\hline
\end{tabular}


Table 3 (Cont.)

\begin{tabular}{|c|c|c|c|c|c|}
\hline Authors & Date & Location & Topic & Species & Document Content \\
\hline $\begin{array}{l}\text { Schauer and } \\
\text { Murphy }\end{array}$ & 1996 & Alaska & Ecology & Common murre & $\begin{array}{l}\text { This paper presents the results of studies of predation on } \\
\text { eggs and nestlings of common murres at Bluff, Alaska. }\end{array}$ \\
\hline $\begin{array}{l}\text { Sea Duck Joint } \\
\text { Venture }\end{array}$ & 2003 & General & General & Steller's eider & This fact sheet describes the Steller's eider. \\
\hline Solovieva & 1999 & General & Ecology & Steller's eider & $\begin{array}{l}\text { This dissertation discusses research on the biology and } \\
\text { bioenergetics of the Steller's eider. }\end{array}$ \\
\hline Springer et al. & 1996 & $\begin{array}{l}\text { Aleutian } \\
\text { Islands }\end{array}$ & Ecology & Seabirds & $\begin{array}{l}\text { This paper discusses seabirds as indicators of marine } \\
\text { ecosystem conditions. }\end{array}$ \\
\hline Stehn et al. & 2001 & Alaska & Population & Seabirds & $\begin{array}{l}\text { This paper discusses the incidental catch of seabirds by } \\
\text { longline fisheries. }\end{array}$ \\
\hline $\begin{array}{l}\text { Stephenson and } \\
\text { Irons }\end{array}$ & 2003 & $\begin{array}{l}\text { Bering Sea, } \\
\text { Gulf of Alaska }\end{array}$ & Population & Colonial seabirds & $\begin{array}{l}\text { This paper discusses differences in colonial nesting } \\
\text { seabird populations in the eastern Bering Sea and Gulf of } \\
\text { Alaska using data from the Beringian Seabird Colony } \\
\text { Database. }\end{array}$ \\
\hline Stout & 2002 & Alaska, Russia & Impacts & Eiders & $\begin{array}{l}\text { Livers and kidney tissues were collected from eiders in } \\
\text { Alaska and Russia for organic and elemental analyses. } \\
\text { Results showed that organochlorine and many elemental } \\
\text { levels were below toxic thresholds; however, in many } \\
\text { cases, cadmium, copper, lead and selenium appeared high } \\
\text { relative to other waterfowl. With the exception of lead, } \\
\text { local anthropogenic sources for these elements are not } \\
\text { known. Although adverse physiological responses have } \\
\text { not been documented in eiders, these four elements } \\
\text { cannot be ruled out as contaminants of potential concern } \\
\text { for some eider species. }\end{array}$ \\
\hline Suydam & 2000 & General & General & King eider & $\begin{array}{l}\text { This chapter describes the life history and ecology of the } \\
\text { king eider. }\end{array}$ \\
\hline
\end{tabular}


Table 3 (Cont.)

\begin{tabular}{|c|c|c|c|c|c|}
\hline Authors & Date & Location & Topic & Species & Document Content \\
\hline $\begin{array}{l}\text { Systad and } \\
\text { Bustnes }\end{array}$ & 2001 & Arctic & Ecology & $\begin{array}{l}\text { Common eider, king eider, } \\
\text { long-tailed duck }\end{array}$ & $\begin{array}{l}\text { This paper describes the effects of darkness and low } \\
\text { temperatures on winter foraging of common eiders, king } \\
\text { eiders, and long-tailed ducks. The numbers of common } \\
\text { eiders and king eiders species remained fairly constant } \\
\text { throughout winter, whereas long-tailed ducks moved out } \\
\text { of the area in midwinter. As day length decreased, eiders } \\
\text { extended their feeding period into lower light intensities. } \\
\text { The ability to survive when days are short might be } \\
\text { explained by use of stored nutrient reserves, night } \\
\text { feeding, or high prey availability. }\end{array}$ \\
\hline
\end{tabular}

\begin{tabular}{|c|c|c|c|c|c|}
\hline Trust et al. & 2000 & $\begin{array}{l}\text { St. Lawrence } \\
\text { Island, Bering } \\
\text { Sea }\end{array}$ & Impacts & Spectacled eider & $\begin{array}{l}\text { Inorganic and organic contaminants were measured in } \\
\text { spectacled eiders from St. Lawrence Island. }\end{array}$ \\
\hline Vander Pol et al. & 2003 & Alaska & Impacts & Murres & $\begin{array}{l}\text { This poster discusses trends in concentrations of organic } \\
\text { pollutants in eggs from murre colonies. }\end{array}$ \\
\hline Vlietstra et al. & 2005 & $\begin{array}{l}\text { Aleutian } \\
\text { Islands }\end{array}$ & Ecology & Short-tailed shearwater & $\begin{array}{l}\text { This paper associates sizes of prey with fronts in Aleutian } \\
\text { passes with respect to the diet of the short-tailed } \\
\text { shearwater. }\end{array}$ \\
\hline Ward et al. & 1999 & $\begin{array}{l}\text { Southwestern } \\
\text { Alaska }\end{array}$ & Impacts & Brant, Canada goose & $\begin{array}{l}\text { Observations of the response of fall-staging brant and } \\
\text { Canada geese to aircraft overflights. }\end{array}$ \\
\hline $\begin{array}{l}\text { Wiese and } \\
\text { Robertson }\end{array}$ & 2004 & General & Impacts & Seabirds & $\begin{array}{l}\text { Presents a computer model for assessing the effects of } \\
\text { chronic exposure of seabirds to low levels of oil } \\
\text { discharge. }\end{array}$ \\
\hline Wiese et al. & 2001 & North Atlantic & Impacts & Seabirds & $\begin{array}{l}\text { This paper discusses the sources of mortality to seabirds } \\
\text { congregating at offshore oil platforms. }\end{array}$ \\
\hline Wilbor & 1999 & Bering Sea & Conservation & Long-tailed duck & This report discusses the status of the long-tailed duck. \\
\hline Wilson et al. & 2004 & Alaska & Impacts & Spectacled eider, king eider & $\begin{array}{l}\text { Reports the levels of metals and trace elements found in } \\
\text { the blood of spectacled and king eiders. }\end{array}$ \\
\hline $\begin{array}{l}\text { Winker and } \\
\text { Rocque }\end{array}$ & 2004 & General & Impact & Seabirds & $\begin{array}{l}\text { This report discusses the use of archived seabird samples } \\
\text { as resources for marine environmental assessment. }\end{array}$ \\
\hline York et al. & 2001 & General & Impact & Seabirds & $\begin{array}{l}\text { This report discusses the use of archived seabird samples } \\
\text { and protocols for collecting and banking seabird eggs. }\end{array}$ \\
\hline
\end{tabular}




\section{MARINE MAMMALS}

This evaluation of information on marine mammals of the Bering Sea, Bristol Bay, and the North Aleutian Basin is based on a collection of about 200 reports, research papers, and web-published materials dated from 1996 to 2006. Information is included on 25 species of cetaceans (whales, porpoises, and dolphins); pinnipeds (seals, sea lions, and walrus); and sea otters. These species are included because (1) they occur in Bristol Bay and adjoining shores, (2) they are wide-ranging in the Bering Sea and cannot be ruled out for regions potentially affected by oil and gas development activities, (3) impacts on them may be similar to those on species occurring in the North Aleutian Basin, or (4) they are part of the subsistence culture of Alaska Natives in Bristol Bay and the southeastern Bering Sea. A few poorly known species, such as the beaked whales, are included because they are mentioned in literature pertaining to other species. Literature concerning mammals in the Chukchi Sea and Beaufort Sea is included when the results of the studies could potentially be extrapolated to mammals of the southeastern Bering Sea.

Presentations at the Planning Meeting included overviews of (1) important pinniped populations by John Bengtson of the National Marine Mammal Laboratory, (2) North Pacific right whale (Eubalaena japonica) and other cetaceans by Philip Clapham of the National Marine Mammal Laboratory, and (3) northern sea otters (Enhydra lutris kenyoni) and Pacific walrus (Odobenus rosmarus divergens) by Angela Doroff of the FWS. The presentations, which can be found in the Planning Meeting report, summarize available information and information needs on these topics relevant to an impact assessment of oil and gas development in the Basin.

Recent literature on marine mammals identified and collected for this report includes general species descriptions; information on distribution and habitat; estimates of population size, population parameters, and dynamics; biotic relationships, including trophic and ecosystem relationships; impacts of human activities; and regulatory status and management. Table 4 presents summaries of the content of selected recent publications. Full citations are presented in Section 7.4.

Since 1996, the regulatory status under the Marine Mammal Protection Act (MMPA) and the Endangered Species Act (ESA) of certain stocks of marine mammals that inhabit the North Aleutian Basin area (e.g., sea otter, North Pacific right whale) has changed. New fishery regulations have been implemented to protect critical habitat for the Steller sea lion (Eumetopias jubatus), and critical habitat has been designated for the North Pacific right whale.

Large areas of critical habitat exist for the Steller sea lion in the Bering Sea. In 2005, the FWS listed the Southwest Alaska distinct population segment of the northern sea otter as threatened under the ESA. In 2006, the NMFS established critical habitat for the North Pacific right whale in the Bering Sea and Gulf of Alaska, and is proposing to expand the area of these habitats and released the draft recovery plan for the fin whale (Balaenoptera physalus).

\footnotetext{
${ }^{2}$ Dr. Lisa Rotterman, Minerals Management Service, Anchorage, provided valuable input for the preparation of this section.
} 
The Marine Mammal Commission prepares annual reports to Congress on the regulation, conservation, management, status, and human impacts to marine mammals listed as threatened and endangered under the ESA or depleted under the MMPA. The American Cetacean Society publishes fact sheets on the general biology, distribution, life history, and status of marine mammals. These fact sheets, which include bibliographies, are available for many of the species found in Bristol Bay and the Bering Sea, such as the Pacific white-sided dolphin (Lagenorhynchus obliquidens), Dall's porpoise (Phocoenoides dalli), and the harbor porpoise (Phocoena phocoena), among others.

Detailed species information on marine mammals is updated periodically and published in Alaska Marine Mammal Stock Assessments. These annual reports contain information on many or all of the marine mammals found in the southeastern Bering Sea. These stock assessments give good, up-to-date summaries of what is known for each species, including (1) stock definition and geographic range; (2) population size, including historic and recent data; (3) current and maximum productivity estimates and potential biological removal; (4) annual human caused mortality and serious injury, including subsistence and commercial harvest; (5) stock status, including regulation and management; and (6) references. The stock assessments also identify data gaps and assessments that cannot be made due to missing or incomplete data.

The MMPA allows Alaska Natives to harvest marine mammals for subsistence uses. Per the MMPA requirements, the FWS has established a Marking, Tagging, and Recording Program under which all sea otter and polar bear hides and skulls, and all walrus tusks, are tagged by a FWS representative. In addition, the FWS monitors the annual spring walrus hunt in several Alaskan villages as part of its Walrus Harvest Monitoring Program. Tagging reports provide information on location, age class, and gender.

The ADFG publishes detailed habitat maps of nearshore waters including habitats of the Pacific walrus, spotted seals (Phoca largha), Steller sea lions, harbor seals (Phoca vitulina), beluga whales (Delphinapterus leucas), and northern sea otters. These maps identify haulouts for walrus, seals, and sea lions, as well as feeding and calving areas for whales. Map coverage includes the shores of southeastern Bristol Bay, including the north shore of the Alaska Peninsula and Aleutian Islands, the south shore of the Alaska Peninsula, and islands of the Gulf of Alaska.

Observations and census of pinnipeds and cetaceans by direct observation and remote sensing have provided information on distribution patterns and migratory routes, as well as population estimates. In 1996, North Pacific right whales were discovered to still be present in the southeastern Bering Sea. Subsequent studies by shipboard observations, aerial surveys, and acoustic analysis have established the relatively regular presence of these whales in the southeastern Bering Sea, including the North Aleutian Basin, during most years.

Recent studies of changes in the distribution of cetaceans (North Pacific right whale, fin whale, western gray whale [Eschrichtius robustus], and humpback whale [Megaptera novaeangliae]) have been evaluated with respect to climate change. Studies published from 1996 to 2006 discuss the relationship of cetacean, pinniped, walrus, and sea otter distributions to bathymetry, oceanic and coastal circulation, sea ice, productivity, and food abundance. 
Observations of Steller sea lions and cetaceans have been related to biophysical variables for the Alaska Peninsula, Aleutian Islands, and the Gulf of Alaska.

While marine mammals are relatively well studied in the Bering Sea compared with other taxonomic groups, little of this information applies specifically to the areas of the North Aleutian Basin where oil and gas development could occur. In order to assess the impacts of development in the Basin, further study of marine mammal movement, habitat use, reproduction, population dynamics, and diet is needed.

Visual observations, radiotelemetry, remote sensing, tagging, capture, and passive acoustics have been used to monitor the populations of cetaceans, pinnipeds, walrus, and sea otters in the Bering Sea, Bristol Bay, and Aleutian Islands. Population parameters studied include stock identification, population genetics, population size, population trends, stock productivity, reproduction, and sources of mortality. These studies provide a historical perspective on population size and change and have been used to predict future population trends and recovery. Decreasing numbers of some species such as Steller sea lions have been investigated from the perspectives of nutrition, prey availability, natural and hunting mortality, disease, and pollution. Various modeling techniques have been developed to assist with assessing population dynamics and proposed recovery measures for cetacean species of regulatory concern, such as bowhead whales. Remote sensing techniques have been developed for some species, such as the Pacific walrus (using airborne thermal sensors) and the spotted seal (using satellite-linked transmitters). Few of these data are specific to the North Aleutian Basin, but they could be used for assessments if the population sizes and distributions of marine mammals in the Basin have been determined.

Recent studies of diet and trophic relationships of marine mammals include analyses of temporal and geographic variation. Diets of northern fur seals (Callorhinus ursinus), Steller sea lions, and sea otters have been investigated to try to better understand observed geographic patterns and recent population changes. Levels of organic pollutants in marine mammals have been interpreted on the basis of diet. In recent years, food webs have undergone major changes in the Bering Sea. Changes in ecosystem structure have been implicated in changes in marine mammal body condition, growth, and population size. Declines of prey species and changes in ecosystem structure have been hypothesized to be related to interdecadal changes in climate, major climate events, and a trend of increasing temperature. Studies of variability in sea ice, circulation patterns across the Bering Shelf, and circulation through Aleutian passes have been interpreted as affecting selected marine mammal populations. These recent changes in the Bering Sea ecosystem create a need for continued study of marine mammal seasonal habitat use, seasonal diet, condition, and health status.

Oil spill impacts on marine environments have been extensively studied in Prince William Sound, including population trends, body condition, and survival of sea otters following the Exxon Valdez oil spill in Prince William Sound. Other potential impacts from oil and gas development include disturbance by activities on the Outer Continental Shelf, including drilling, transportation, and exploration. Contaminants in marine mammals have been studied from the perspectives of human health, marine mammal population effects, and food chain transfer. 
Information about the subsistence harvest of seals, sea lions, whales, and sea otters has been monitored by the ADFG, FWS, and NMFS (depending on the species).

Human activities such as oil and gas exploration and production, commercial fisheries, Naval activities, and whale watching may affect marine mammals as a result of increases in noise and disturbance from breaking ice, vessel traffic and ship strikes, harassment, illegal shooting, research seismic surveys, and pollution. Behavioral changes of marine mammals due to disturbance by these activities needs further study. Oil and gas exploration, development, and production activities will generate noise to which cetaceans and pinnipeds are sensitive. Studies of acoustic effects on species that inhabit the North Aleutian Basin should be implemented. 
TABLE 4. Publications from 1996 to 2006 Related to Marine Mammals of the North Aleutian Basin.

\begin{tabular}{|c|c|c|c|c|c|}
\hline Authors & Date & Location & Topic & Species & Document Content \\
\hline ADFG & $1997 \mathrm{a}$ & Togiak Bay & Distribution & $\begin{array}{l}\text { Pacific walrus, harbor seal, } \\
\text { spotted seal, Steller sea lion }\end{array}$ & $\begin{array}{l}\text { Map of Togiak Bay showing haulout areas for walrus, } \\
\text { harbor and spotted seals, and sea lions. }\end{array}$ \\
\hline $\mathrm{ADFG}$ & $1997 b$ & Nushagak Bay & Distribution & $\begin{array}{l}\text { Harbor seal, spotted seal, beluga } \\
\text { whale }\end{array}$ & $\begin{array}{l}\text { Map of Nushagak Bay showing beluga whale calving } \\
\text { and harbor and spotted seal haulout areas. }\end{array}$ \\
\hline $\mathrm{ADFG}$ & $1997 \mathrm{c}$ & Kvichak Bay & Distribution & Harbor seal, beluga whale & $\begin{array}{l}\text { Map of Kvichak Bay showing beluga whale calving } \\
\text { and feeding areas and haulout areas for harbor seals. }\end{array}$ \\
\hline ADFG & $1997 d$ & Egigik Bay & Distribution & Harbor seal, beluga whale & $\begin{array}{l}\text { Map of Egigik Bay showing beluga whale feeding } \\
\text { areas and harbor seal haulout areas. }\end{array}$ \\
\hline $\mathrm{ADFG}$ & $1997 \mathrm{e}$ & Ugashik Bay & Distribution & Harbor seal & $\begin{array}{l}\text { Map of Ugashik Bay showing harbor seal haulout } \\
\text { areas. }\end{array}$ \\
\hline ADFG & $1997 f$ & Cinder River area & Distribution & Harbor seal & $\begin{array}{l}\text { Map of the Cinder River area showing harbor seal } \\
\text { haulout areas. }\end{array}$ \\
\hline $\mathrm{ADFG}$ & $1997 \mathrm{~g}$ & Port Heiden area & Distribution & Harbor seal & $\begin{array}{l}\text { Map of the Port Heiden area showing harbor seal } \\
\text { haulout areas. }\end{array}$ \\
\hline $\mathrm{ADFG}$ & $1997 \mathrm{~h}$ & Kujulik Bay area & Distribution & $\begin{array}{l}\text { Steller sea lion, northern sea } \\
\text { otter }\end{array}$ & $\begin{array}{l}\text { Map of the Kujulik Bay area showing areas of northern } \\
\text { sea otter concentration and Steller sea lion haulout } \\
\text { areas. }\end{array}$ \\
\hline $\begin{array}{l}\text { Agler and } \\
\text { Kendall }\end{array}$ & 1997 & $\begin{array}{l}\text { Prince William } \\
\text { Sound }\end{array}$ & Impacts & Sea otter & $\begin{array}{l}\text { Report describes trends in sea otter population } \\
\text { abundance of Prince William Sound following the } \\
\text { Exxon Valdez oil spill. }\end{array}$ \\
\hline $\begin{array}{l}\text { Alaska } \\
\text { Fisheries } \\
\text { Science Center }\end{array}$ & 2006 & Alaska & $\begin{array}{l}\text { Multiple } \\
\text { topics }\end{array}$ & Marine mammals & $\begin{array}{l}\text { A searchable database of all Alaska Fisheries Science } \\
\text { Center and National Marine Mammals Library } \\
\text { publications. }\end{array}$ \\
\hline $\begin{array}{l}\text { Alaska Science } \\
\text { Center }\end{array}$ & 2004 & $\begin{array}{l}\text { Bering Sea, } \\
\text { Chukchi Sea }\end{array}$ & Ecology & Pacific walrus & $\begin{array}{l}\text { Website maintained by the Alaska Science Center with } \\
\text { links to the Pacific walrus international database. }\end{array}$ \\
\hline $\begin{array}{l}\text { Alaska Sea } \\
\text { Life Center }\end{array}$ & 2006 & Alaska & $\begin{array}{l}\text { Various } \\
\text { topics }\end{array}$ & Marine mammals & $\begin{array}{l}\text { Website with a bibliography of more than } 175 \text { peer- } \\
\text { reviewed publications. }\end{array}$ \\
\hline $\begin{array}{l}\text { American } \\
\text { Cetacean } \\
\text { Society }\end{array}$ & 2004 & Worldwide & General & Pacific white-sided dolphin & $\begin{array}{l}\text { Fact sheet describing the biology, distribution, life } \\
\text { history, and status of the Pacific-white-sided dolphin. } \\
\text { A bibliography is included. }\end{array}$ \\
\hline
\end{tabular}


Table 4 (Cont.)

\begin{tabular}{|c|c|c|c|c|c|}
\hline Authors & Date & Location & Topic & Species & Document Content \\
\hline $\begin{array}{l}\text { American } \\
\text { Cetacean } \\
\text { Society }\end{array}$ & $2005 a$ & Worldwide & General & Dall's porpoise & $\begin{array}{l}\text { Fact sheet describing the biology, distribution, life } \\
\text { history, and status of the Dall's porpoise. A } \\
\text { bibliography is included. }\end{array}$ \\
\hline $\begin{array}{l}\text { American } \\
\text { Cetacean } \\
\text { Society }\end{array}$ & $2005 b$ & Worldwide & General & Harbor porpoise & $\begin{array}{l}\text { Fact sheet describing the biology, distribution, life } \\
\text { history, and status of the harbor porpoise. A } \\
\text { bibliography is included. }\end{array}$ \\
\hline $\begin{array}{l}\text { Angliss and } \\
\text { Outlaw }\end{array}$ & 2005 & Alaska & General & Marine mammals & $\begin{array}{l}\text { Detailed descriptions are provided for each regional } \\
\text { stock of marine mammals in Alaskan waters. The stock } \\
\text { assessments are updated to } 2005 \text {. Descriptions include } \\
\text { stock definitions and geographic range, population size } \\
\text { and trends, stock productivity, fisheries, } \\
\text { subsistence/native harvest, other sources of mortality, } \\
\text { stock status, and habitat concerns. }\end{array}$ \\
\hline Angliss et al. & 2002 & Worldwide & Regulation & $\begin{array}{l}\text { Blue whale, North Pacific right } \\
\text { whale, Steller sea lion, } \\
\text { humpback whale }\end{array}$ & $\begin{array}{l}\text { This report presents the results of a February } 2001 \\
\text { workshop on developing recovery criteria for large } \\
\text { whale species. The workshop reviewed regulatory } \\
\text { history and developed a general framework for } \\
\text { recovery criteria. }\end{array}$ \\
\hline Antonelis et al. & 1997 & Bering Sea & Ecology & Northern fur seal & $\begin{array}{l}\text { Reports studies of the interisland variation in the diet } \\
\text { of female northern fur seals in the Bering Sea. }\end{array}$ \\
\hline Baker et al. & 2005 & North Pacific & Population & Steller sea lion & $\begin{array}{l}\text { Genetic analyses of individuals from all known } \\
\text { significant rookeries found no evidence of genetic } \\
\text { bottleneck effects, and found significant divergence } \\
\text { between eastern and western stock animals and } \\
\text { between Asian rookeries and other western stock } \\
\text { rookeries. Recommends three stocks be recognized. }\end{array}$ \\
\hline Bengtson et al. & 1999 & Bering Sea & Ecology & Seals & $\begin{array}{l}\text { Discusses the life history of seals in term of } \\
\text { interdecadal changes in Bering Sea ecosystems. }\end{array}$ \\
\hline Brownell et al. & 2001 & North Pacific & Conservation & North Pacific right whale & $\begin{array}{l}\text { Discusses the conservation status of North Pacific right } \\
\text { whales. }\end{array}$ \\
\hline Brueggeman & 1998 & $\begin{array}{l}\text { North Aleutian } \\
\text { Basin }\end{array}$ & Distribution & Marine mammals & $\begin{array}{l}\text { Discusses marine habitat use in the MMS planning } \\
\text { areas of the North Aleutian Basin, St. George Basin, } \\
\text { and the Gulf of Alaska. }\end{array}$ \\
\hline
\end{tabular}


Table 4 (Cont.)

\begin{tabular}{|c|c|c|c|c|c|}
\hline Authors & Date & Location & Topic & Species & Document Content \\
\hline $\begin{array}{l}\text { Buckland and } \\
\text { Breiwick }\end{array}$ & 2002 & Eastern Pacific & Population & Gray whale & $\begin{array}{l}\text { Discusses trends in abundance of eastern Pacific gray } \\
\text { whales estimated from shore counts from 1967-1968 to } \\
\text { 1995-1996. }\end{array}$ \\
\hline Burek et al. & 2005 & $\begin{array}{l}\text { Gulf of Alaska, } \\
\text { Aleutian Islands }\end{array}$ & Population & Steller sea lion & $\begin{array}{l}\text { Serologic data were examined to determine whether } \\
\text { infectious disease may have played a role in the decline } \\
\text { of Steller sea lions in the Gulf of Alaska and Aleutian } \\
\text { Islands. }\end{array}$ \\
\hline Burn & 1998 & Bering Sea & Regulation & Pacific walrus & $\begin{array}{l}\text { Estimates hunter compliance with the Marine Mammal } \\
\text { Marking, Tagging and Reporting Program for walrus. }\end{array}$ \\
\hline $\begin{array}{l}\text { Burn and } \\
\text { Perryman }\end{array}$ & 1999 & Bering Sea & Population & Pacific walrus & $\begin{array}{l}\text { Discusses application of remote sensing to walrus } \\
\text { studies in Alaska. }\end{array}$ \\
\hline Burn et al. & 2003 & Bering Sea & Population & Pacific walrus & $\begin{array}{l}\text { This paper reports on tests of airborne thermal imagery } \\
\text { of Pacific walrus to determine if this technology can be } \\
\text { used to detect walrus groups on sea ice and estimate } \\
\text { the number of walruses present in each group. The } \\
\text { study identified a significant linear relation between } \\
\text { walrus group size and the amount of heat measured by } \\
\text { the thermal sensor. Results of this study indicate that } \\
\text { an aerial survey using a thermal sensor can cover as } \\
\text { much as } 4 \text { times the area per hour of flight time with } \\
\text { greater reliability than visual observation. }\end{array}$ \\
\hline $\begin{array}{l}\text { Butterworth } \\
\text { et al. }\end{array}$ & $2002 a$ & Bering Sea & Population & Gray whale & $\begin{array}{l}\text { Discusses dynamic response analysis for the North } \\
\text { Pacific gray whale population. }\end{array}$ \\
\hline $\begin{array}{l}\text { Butterworth } \\
\text { et al. }\end{array}$ & $2002 b$ & Bering Sea & Population & Gray whale & $\begin{array}{l}\text { Discusses modeling of the North Pacific gray whale } \\
\text { population. }\end{array}$ \\
\hline $\begin{array}{l}\text { Calambokidis } \\
\text { et al. }\end{array}$ & 1996 & North Pacific & Population & Humpback whale & $\begin{array}{l}\text { Discusses interchange and isolation between humpback } \\
\text { whales off California and other North Pacific feeding } \\
\text { grounds. }\end{array}$ \\
\hline Calkins et al. & 1998 & Alaska & Population & Steller sea lion & $\begin{array}{l}\text { Evaluates nutritional stress as a cause for the decline in } \\
\text { numbers of Steller sea lions in the Gulf of Alaska, the } \\
\text { Aleutian Islands, and the Bering Sea. }\end{array}$ \\
\hline
\end{tabular}


Table 4 (Cont.)

\begin{tabular}{|c|c|c|c|c|c|}
\hline Authors & Date & Location & Topic & Species & Document Content \\
\hline $\begin{array}{l}\text { Call and } \\
\text { Loughlin }\end{array}$ & 2005 & $\begin{array}{l}\text { Aleutian Islands, } \\
\text { Gulf of Alaska }\end{array}$ & Ecology & Steller sea lion & $\begin{array}{l}\text { This paper presents a broad ecological characterization } \\
\text { of rookeries for the western stock of Steller sea lions to } \\
\text { inform management decisions for their recovery. Data } \\
\text { on habitat, diet, and population trends were used to } \\
\text { group sea lion rookeries into ecologically related } \\
\text { regions. Five distinct classes of rookeries (potential } \\
\text { management regions) were identified. }\end{array}$ \\
\hline $\begin{array}{l}\text { Cascadia } \\
\text { Research }\end{array}$ & 2006 & North Pacific & $\begin{array}{l}\text { Abundance, } \\
\text { population, } \\
\text { human } \\
\text { impacts }\end{array}$ & Humpback whale & $\begin{array}{l}\text { This website presents the results of the "Structure of } \\
\text { Populations, Levels of Abundance, and Status of } \\
\text { Humpbacks" (SPLASH) project that examined } \\
\text { population structure, abundance, and human impacts }\end{array}$ \\
\hline
\end{tabular}

\begin{tabular}{|c|c|c|c|c|}
\hline Castellini et al. & 1996 & Alaska & General & Harbor seal \\
\hline $\begin{array}{l}\text { Chadwick } \\
\text { et al. }\end{array}$ & 1996 & Chukchi Sea & Impacts & Pacific walrus \\
\hline Chivers & 1999 & North Pacific & Population & Pacific walrus \\
\hline Chivers et al. & 2002 & North Pacific & Population & Harbor porpoise \\
\hline $\begin{array}{l}\text { Clark and } \\
\text { Ellison }\end{array}$ & 2000 & $\begin{array}{l}\text { Bering, Chukchi, } \\
\text { \& Beaufort Seas }\end{array}$ & Distribution & Bowhead whale \\
\hline $\begin{array}{l}\text { Clarke and } \\
\text { Moore }\end{array}$ & 2002 & $\begin{array}{l}\text { Bering Sea, } \\
\text { Chukchi Sea }\end{array}$ & Distribution & Gray whale \\
\hline Clark et al. & 1996 & $\begin{array}{l}\text { Bering Sea, } \\
\text { Chukchi Sea, } \\
\text { Beaufort Sea }\end{array}$ & Distribution & Bowhead whale \\
\hline
\end{tabular}
for humpback whales in the North Pacific.

Reports annual investigations on harbor seals in Alaska.

Reports preliminary research on the potential effects of disturbance in the Outer Continental Shelf.

This report discusses biological indices using models to monitor the population status of walrus.

Molecular genetic analysis is used to evaluate smallscale population structure of eastern North Pacific harbor porpoises.

Acoustic location methods for bowhead whales are calibrated and compared.

Report of observations of gray whales in the southern Chukchi and northern Bering Seas during AugustNovember 1980-1989.

An acoustic study was conducted off Point Barrow, Alaska, in spring 1993 as part of the continuing effort to census the Bering-Chukchi-Beaufort Sea bowhead whale population. The offshore distribution of acoustically located whales indicates that throughout the 1993 migration period, $86 \%$ of the vocalizing animals were within $4 \mathrm{~km}$ of the nearshore ice edge. 
Table 4 (Cont.)

\begin{tabular}{|c|c|c|c|c|c|}
\hline Authors & Date & Location & Topic & Species & Document Content \\
\hline Coffing et al. & 1998 & $\begin{array}{l}\text { Yukon- } \\
\text { Kuskokwim } \\
\text { Delta }\end{array}$ & Impacts & $\begin{array}{l}\text { Bearded seal, ribbon seal, ringed } \\
\text { seal, spotted seal, Steller sea lion }\end{array}$ & $\begin{array}{l}\text { The subsistence harvest of seals and sea lions by } \\
\text { Alaska Natives in three communities of the Yukon- } \\
\text { Kuskowim Delta during 1997-1998 is reported. }\end{array}$ \\
\hline Coffing et al. & 1999 & $\begin{array}{l}\text { Yukon- } \\
\text { Kuskokwim } \\
\text { Delta }\end{array}$ & Impacts & $\begin{array}{l}\text { Bearded seal, ribbon seal, ringed } \\
\text { seal, spotted seal, Steller sea lion }\end{array}$ & $\begin{array}{l}\text { The subsistence harvest of seals and sea lions by } \\
\text { Alaska Natives in three communities of the Yukon- } \\
\text { Kuskowim Delta during 1998-1999 is reported. }\end{array}$ \\
\hline Coombs et al. & 2003 & Bering Sea & Ecology & Marine mammals & $\begin{array}{l}\text { This paper assesses the impact of contaminants on } \\
\text { marine mammals and human health in the eastern } \\
\text { Bering Sea. }\end{array}$ \\
\hline Da Silva et al. & 2000 & General & Population & Bowhead whale & $\begin{array}{l}\text { Capture-recapture techniques using photo- } \\
\text { identification were used to estimate bowhead whale } \\
\text { population size. }\end{array}$ \\
\hline Dahlheim et al. & 2000 & $\begin{array}{l}\text { Bristol Bay, Gulf } \\
\text { of Alaska }\end{array}$ & Population & Harbor porpoise & $\begin{array}{l}\text { Aerial surveys were used to estimate harbor porpoise } \\
\text { abundance. }\end{array}$ \\
\hline Dehn et al. & 2002 & Alaska & $\begin{array}{l}\text { Ecology, } \\
\text { impacts }\end{array}$ & $\begin{array}{l}\text { Ringed seal, spotted seal, } \\
\text { bearded seal }\end{array}$ & $\begin{array}{l}\text { Discusses feeding ecology of arctic phocids to evaluate } \\
\text { implications for heavy metal dynamics. }\end{array}$ \\
\hline Dehn et al. & 2003 & Alaska & $\begin{array}{l}\text { Ecology, } \\
\text { impacts }\end{array}$ & Ringed seal, spotted seal & $\begin{array}{l}\text { Heavy metals in renal and hepatic tissue of ringed, } \\
\text { bearded, and spotted seals was evaluated in relation to } \\
\text { age and diet. }\end{array}$ \\
\hline DeMaster et al. & 1996 & $\begin{array}{l}\text { Bering Sea, } \\
\text { Chukchi Sea, } \\
\text { Beaufort Sea }\end{array}$ & Population & Seals & $\begin{array}{l}\text { This paper evaluates data on ice-associated seals from } \\
1975 \text { to } 1991 \text {. }\end{array}$ \\
\hline DeMaster et al. & 1997 & Alaska & Population & Ringed seal & $\begin{array}{l}\text { This paper presents observations on the distribution } \\
\text { and abundance of ringed seals in northern Alaska in } \\
\text { May } 1996 .\end{array}$ \\
\hline DeMaster et al. & 2001 & Norton Sound & Population & Beluga whale & $\begin{array}{l}\text { This paper evaluates the effect of sea condition on } \\
\text { estimates of beluga whales, and makes } \\
\text { recommendations for survey methods. }\end{array}$ \\
\hline
\end{tabular}


Table 4 (Cont.)

\begin{tabular}{|c|c|c|c|c|c|}
\hline Authors & Date & Location & Topic & Species & Document Content \\
\hline DOC & 2002 & $\begin{array}{l}\text { Bering Sea, } \\
\text { Beaufort Sea }\end{array}$ & Ecology & Bowhead whale & $\begin{array}{l}\text { In this Federal Register notice, NMFS concludes not to act on } \\
\text { a petition to designate certain areas of the Beaufort Sea as } \\
\text { critical habitat for the Beaufort Sea stock of bowhead whales. } \\
\text { The determination summarizes the state of knowledge of } \\
\text { bowhead ecology in the Bering and Beaufort Seas. }\end{array}$ \\
\hline DOC & 2006 & $\begin{array}{l}\text { Bering Sea, Gulf of } \\
\text { Alaska }\end{array}$ & Regulation & North Pacific right whale & $\begin{array}{l}\text { In this Federal Register notice, NMFS designates areas of the } \\
\text { Bering Sea and the Gulf of Alaska as critical habitat for the } \\
\text { North Pacific right whale. The determination includes a } \\
\text { summary of the status of the species. }\end{array}$ \\
\hline DOD & 1999 & Beaufort Sea & Impacts & Marine mammals & $\begin{array}{l}\text { This final EIS assesses the impact of oil and gas development } \\
\text { for the Northstar project. }\end{array}$ \\
\hline DOI & 2000 & Aleutian Islands & Regulation & Northern sea otter & $\begin{array}{l}\text { This } 2000 \text { determination is a notice of designation of the } \\
\text { northern sea otter in the Aleutian Islands as a candidate } \\
\text { species. }\end{array}$ \\
\hline Eberhardt et al. & 2005 & $\begin{array}{l}\text { Aleutian Islands, } \\
\text { Gulf of Alaska }\end{array}$ & Population & Steller sea lion & $\begin{array}{l}\text { This paper attempts to project trends of Steller sea lion } \\
\text { populations in six subdivisions of the western Alaska } \\
\text { population. Populations were predicted to increase in three } \\
\text { areas, decrease in two areas, and be relatively stable in } \\
\text { another area. }\end{array}$ \\
\hline Estes et al. & 1997 & Aleutian Islands & $\begin{array}{l}\text { Ecology, } \\
\text { impacts }\end{array}$ & Northern sea otter & $\begin{array}{l}\text { This paper evaluates organochlorines in northern sea otters } \\
\text { from the Aleutian Islands. }\end{array}$ \\
\hline Evans et al. & 1997 & Aleutian Islands & Population & Northern sea otter & $\begin{array}{l}\text { This report discusses the distribution and relative abundance } \\
\text { of northern sea otters in the Aleutian Islands. }\end{array}$ \\
\hline Fadely et al. & 2005 & Aleutian Islands & Ecology & Spotted seal & $\begin{array}{l}\text { This paper evaluated the extent that oceanographic features } \\
\text { and bathymetry influenced the diving activity of } 30 \text { immature } \\
\text { sea lions in the eastern Aleutian Islands. Locations associated } \\
\text { with diving to }>4 \text { m were within } 10 \text { nautical miles of shore } \\
\text { and associated with onshelf waters }<100 \text { m deep. Diving } \\
\text { activity varied coincidently with increases in sea surface } \\
\text { temperature and chlorophyll a concentrations and sea lion } \\
\text { age. Immature sea lions developing into independent foragers } \\
\text { in the relatively shallow pass areas did so at a time of rapid } \\
\text { changes in oceanography and prey availability. }\end{array}$ \\
\hline
\end{tabular}


Table 4 (Cont.)

\begin{tabular}{|c|c|c|c|c|c|}
\hline Authors & Date & Location & Topic & Species & Document Content \\
\hline Fay et al. & 1997 & Alaska & Population & Pacific walrus & $\begin{array}{l}\text { This paper evaluates the status of the Pacific walrus } \\
\text { population from } 1950 \text { to } 1989 \text {. }\end{array}$ \\
\hline Fedoseev & 2000 & North Pacific & Ecology & Seals & $\begin{array}{l}\text { This report discusses the biology of ice-associated } \\
\text { seals and their role in North Pacific ecosystems. }\end{array}$ \\
\hline Ferrero & 1996 & North Pacific & Population & Pacific white-sided dolphin & $\begin{array}{l}\text { This report discusses growth patterns of the Pacific } \\
\text { white-sided dolphin in the central North Pacific. }\end{array}$ \\
\hline $\begin{array}{l}\text { Ferrero and } \\
\text { Walker }\end{array}$ & 1996 & North Pacific & Population & Pacific white-sided dolphin & $\begin{array}{l}\text { This paper measures age, growth, and reproductive } \\
\text { patterns of the Pacific white-sided dolphin taken in } \\
\text { high-seas driftnets in the central North Pacific Ocean. }\end{array}$ \\
\hline Folkens & 2003 & General & $\begin{array}{l}\text { Population, } \\
\text { impacts }\end{array}$ & Marine mammals & $\begin{array}{l}\text { This paper discusses global climate change and } \\
\text { implications for marine mammal survival. }\end{array}$ \\
\hline $\begin{array}{l}\text { Forney and } \\
\text { Brownell }\end{array}$ & 1996 & Aleutian Islands & Population & Marine mammals & $\begin{array}{l}\text { This paper gives a preliminary report of a } 1994 \\
\text { Aleutian Island marine mammal survey. }\end{array}$ \\
\hline $\begin{array}{l}\text { Fritz and } \\
\text { Hinckley }\end{array}$ & 2005 & $\begin{array}{l}\text { Gulf of Alaska, } \\
\text { Aleutian Islands, } \\
\text { Bering Sea }\end{array}$ & Population & Steller sea lion & $\begin{array}{l}\text { This study evaluated the nutritional stress hypotheses } \\
\text { for explaining the decline in the western Steller sea } \\
\text { lion population. Little support was found for the } \\
\text { hypothesis. }\end{array}$ \\
\hline FWS & $2006 \mathrm{a}$ & Alaska & $\begin{array}{l}\text { Threatened } \\
\text { and } \\
\text { endangered } \\
\text { species }\end{array}$ & $\begin{array}{l}\text { Polar bear, northern sea otter, } \\
\text { Pacific walrus }\end{array}$ & $\begin{array}{l}\text { FWS Alaska Endangered Species Listing Program } \\
\text { website. This website provides information on a } \\
\text { variety of species listed under the ESA, and links to a } \\
\text { variety of species-specific information. }\end{array}$ \\
\hline FWS & $2006 b$ & Alaska & $\begin{array}{l}\text { Ecology, } \\
\text { population, } \\
\text { harvest }\end{array}$ & $\begin{array}{l}\text { Polar bear, northern sea otter, } \\
\text { Pacific walrus }\end{array}$ & $\begin{array}{l}\text { FWS Alaska marine mammals management website } \\
\text { with some downloadable reports and a publication } \\
\text { listing. }\end{array}$ \\
\hline FWS & $2006 \mathrm{c}$ & Alaska & $\begin{array}{l}\text { Population, } \\
\text { subsistence } \\
\text { hunting }\end{array}$ & Sea otter and walrus & $\begin{array}{l}\text { Annual Marking, Tagging, and Reporting Program and } \\
\text { the Walrus Harvest Monitoring Program tagging } \\
\text { reports provide location, age class, and sex data for sea } \\
\text { otters and walrus harvested by Alaskan Natives. }\end{array}$ \\
\hline FWS & $2006 d$ & Alaska & $\begin{array}{l}\text { Endangered } \\
\text { and } \\
\text { threatened } \\
\text { species }\end{array}$ & Northern sea otter & $\begin{array}{l}\text { FWS website providing information on listing of the } \\
\text { Southwest Alaska Distinct Population Segment of the } \\
\text { northern sea otter; includes access to all listing } \\
\text { documents and special rules. }\end{array}$ \\
\hline
\end{tabular}


Table 4 (Cont.)

\begin{tabular}{|c|c|c|c|c|c|}
\hline Authors & Date & Location & Topic & Species & Document Content \\
\hline Garlich-Miller & 1997 & Bering Strait & Population & Pacific walrus & $\begin{array}{l}\text { This report presents data on age, gender, and } \\
\text { reproductive status of the Pacific walrus harvested in } \\
\text { the Bering Strait region from } 1994 \text { to } 1996 .\end{array}$ \\
\hline $\begin{array}{l}\text { Garlich-Miller } \\
\text { and Burn }\end{array}$ & 1999 & Alaska & Population & Pacific walrus & $\begin{array}{l}\text { This paper reports the results of surveys of harvest of } \\
\text { the Pacific walrus in Alaska and Chukotka, including } \\
\text { communities in the Bering Sea, Chukchi Sea, and Gulf } \\
\text { of Alaska. }\end{array}$ \\
\hline $\begin{array}{l}\text { Garlich-Miller } \\
\text { and Jay }\end{array}$ & 2000 & Alaska & Population & Pacific walrus & $\begin{array}{l}\text { This report is the proceedings of a workshop } \\
\text { concerning walrus survey methods. }\end{array}$ \\
\hline $\begin{array}{l}\text { Garlich-Miller } \\
\text { and Pungowiyi }\end{array}$ & 1999 & Alaska & $\begin{array}{l}\text { Population, } \\
\text { impacts }\end{array}$ & Pacific walrus & $\begin{array}{l}\text { This report is the proceedings of a workshop } \\
\text { concerning walrus harvest in Alaska and Chukotka. }\end{array}$ \\
\hline $\begin{array}{l}\text { Garlich-Miller } \\
\text { et al. }\end{array}$ & 2006 & Bering Strait & Population & Pacific walrus & $\begin{array}{l}\text { This paper reports age and population structure of } \\
\text { walruses harvested in the Bering Strait over the past } 50 \\
\text { years. }\end{array}$ \\
\hline Gelatt & 1996 & Aleutian Islands & Ecology & Northern sea otter & $\begin{array}{l}\text { This thesis presents studies of activity patterns and } \\
\text { time budgets of sea otters at Amchitka Island. }\end{array}$ \\
\hline George et al. & 2001 & $\begin{array}{l}\text { Bering Sea, } \\
\text { Chukchi Sea, } \\
\text { Beaufort Sea }\end{array}$ & Ecology & Bowhead whale & $\begin{array}{l}\text { This paper looks at energetic adaptations of the } \\
\text { bowhead whale. }\end{array}$ \\
\hline George et al. & 2002 & $\begin{array}{l}\text { Bering Sea, } \\
\text { Chukchi Sea, } \\
\text { Beaufort Sea }\end{array}$ & Population & Bowhead whale & $\begin{array}{l}\text { This paper reports the population size of the Bering- } \\
\text { Chukchi-Beaufort Sea stock of bowhead whales, based } \\
\text { on the } 2001 \text { census off Point Barrow. }\end{array}$ \\
\hline Givens & 2000 & General & Population & Bowhead whale & $\begin{array}{l}\text { Gives an example of strike limit algorithm } \\
\text { optimization. }\end{array}$ \\
\hline Givens & 2003 & General & $\begin{array}{l}\text { Population, } \\
\text { impacts }\end{array}$ & Bowhead whale & $\begin{array}{l}\text { Estimates safe aboriginal whaling limits for bowhead } \\
\text { whales. }\end{array}$ \\
\hline $\begin{array}{l}\text { Givens and } \\
\text { Bravington }\end{array}$ & 1996 & General & Population & Bowhead whale & $\begin{array}{l}\text { Evaluates sensitivity and adequacy of modeling of } \\
\text { bowhead whale stocks. }\end{array}$ \\
\hline $\begin{array}{l}\text { Goddard and } \\
\text { Rugh }\end{array}$ & 1998 & Bering Sea & Distribution & North Pacific right whale & $\begin{array}{l}\text { This paper reports a siting of a group of right whales in } \\
\text { the Bering Sea in July } 1996 .\end{array}$ \\
\hline
\end{tabular}


Table 4 (Cont.)

\begin{tabular}{|c|c|c|c|c|c|}
\hline Authors & Date & Location & Topic & Species & Document Content \\
\hline Greene et al. & 2003 & Alaska & Population & Bowhead whale & $\begin{array}{l}\text { This report discusses the use of DIFAR sensors to } \\
\text { locate calling bowhead whales and monitor their } \\
\text { migration. }\end{array}$ \\
\hline $\begin{array}{l}\text { Gudmundson } \\
\text { et al. }\end{array}$ & 2006 & Bering Sea & Ecology & Northern fur seal & $\begin{array}{l}\text { The diet of northern fur seals was studied by } \\
\text { examining scat or spews to determine size and age } \\
\text { composition of prey. }\end{array}$ \\
\hline Hastings & 2001 & Bering Sea & Impacts & Harbor seal & $\begin{array}{l}\text { Data from Alaska were compared with data on harbor } \\
\text { seals from other areas to evaluate the need for further } \\
\text { study. }\end{array}$ \\
\hline $\begin{array}{l}\text { Hill and } \\
\text { DeMaster }\end{array}$ & 1999 & Alaska & $\begin{array}{l}\text { Population, } \\
\text { impacts }\end{array}$ & Cetaceans & $\begin{array}{l}\text { This report provides information on the marine } \\
\text { mammal stocks of Alaska under the jurisdiction of the } \\
\text { NMFS, and includes a description of the stock's } \\
\text { geographic range, a minimum population estimate, } \\
\text { current population trends, current and maximum net } \\
\text { productivity rates, optimum sustainable population } \\
\text { levels and allowable removal levels, and estimates of } \\
\text { annual human-caused mortality and serious injury }\end{array}$ \\
\hline Hill et al. & 1997 & Alaska & $\begin{array}{l}\text { Population, } \\
\text { impacts }\end{array}$ & Cetaceans & $\begin{array}{l}\text { This report provides information on the marine } \\
\text { mammal stocks of Alaska under the jurisdiction of the } \\
\text { NMFS. Each stock assessment includes a description } \\
\text { of the stock's geographic range, a minimum population } \\
\text { estimate, current population trends, current and } \\
\text { maximum net productivity rates, optimum sustainable } \\
\text { population levels and allowable removal levels, and } \\
\text { estimates of annual human-caused mortality and } \\
\text { serious injury through interactions with commercial } \\
\text { fisheries and subsistence hunters. }\end{array}$ \\
\hline Hills & 2001 & Alaska & Ecology & Pacific walrus & $\begin{array}{l}\text { This paper discusses movements and behavior of male } \\
\text { Pacific walruses in spring and early summer. }\end{array}$ \\
\hline Hirons & 1996 & $\begin{array}{l}\text { Bering Sea, Gulf } \\
\text { of Alaska }\end{array}$ & Ecology & $\begin{array}{l}\text { Steller sea lion, northern fur seal, } \\
\text { harbor seal }\end{array}$ & $\begin{array}{l}\text { This paper reports the use of stable carbon and nitrogen } \\
\text { isotope analysis to investigate the trophic relations of } \\
\text { Alaska pinnipeds in the Bering Sea and Gulf of Alaska. }\end{array}$ \\
\hline
\end{tabular}


Table 4 (Cont.)

\begin{tabular}{|c|c|c|c|c|c|}
\hline Authors & Date & Location & Topic & Species & Document Content \\
\hline Hirons et al. & 2001 & $\begin{array}{l}\text { Bering Sea, Gulf } \\
\text { of Alaska }\end{array}$ & Ecology & $\begin{array}{l}\text { Steller sea lion, northern fur seal, } \\
\text { harbor seal }\end{array}$ & $\begin{array}{l}\text { This paper reports the use of stable carbon and nitrogen } \\
\text { isotope analysis to investigate the trophic relations of } \\
\text { Alaska pinnipeds in the Bering Sea and Gulf of Alaska. } \\
\text { It examines the hypothesis that trophic changes were } \\
\text { related to declines of certain populations. }\end{array}$ \\
\hline $\begin{array}{l}\text { Hobson and } \\
\text { Sease }\end{array}$ & 1998 & Alaska & Ecology & Steller sea lion & $\begin{array}{l}\text { This paper used stable isotope analyses to examine } \\
\text { dietary records of the Steller sea lion. }\end{array}$ \\
\hline Hoekstra et al. & $2002 \mathrm{a}$ & Alaska & Ecology & Bowhead whale & $\begin{array}{l}\text { This paper discusses the trophic ecology of bowhead } \\
\text { whales as determined from carbon, nitrogen, and sulfur } \\
\text { isotope signatures. }\end{array}$ \\
\hline Hoekstra et al. & $2002 b$ & Beaufort Sea & $\begin{array}{l}\text { Ecology, } \\
\text { impacts }\end{array}$ & Bowhead whale & $\begin{array}{l}\text { This paper reports investigations of the } \\
\text { bioaccumulation of organochlorine contaminants in } \\
\text { bowhead whales. }\end{array}$ \\
\hline $\begin{array}{l}\text { Houck and } \\
\text { Jefferson }\end{array}$ & 1999 & General & General & Dall's porpoise & $\begin{array}{l}\text { This chapter describes the life history and biology of } \\
\text { Dall's porpoise. }\end{array}$ \\
\hline Hunt et al. & 2001 & Bering Sea & Ecology & $\begin{array}{l}\text { Pinnipeds, cetaceans, and } \\
\text { northern sea otter }\end{array}$ & $\begin{array}{l}\text { This data gives quantitative data on abundance and } \\
\text { estimates of energy requirements, diet, and prey } \\
\text { consumption for marine mammals in the continental } \\
\text { shelf and pelagic regions of the Bering Sea. }\end{array}$ \\
\hline $\begin{array}{l}\text { International } \\
\text { Whaling } \\
\text { Commission }\end{array}$ & 2006 & Worldwide & Management & Whales & $\begin{array}{l}\text { This report presents reports of International Whaling } \\
\text { Commission observers at various meetings addressing } \\
\text { whale management. It also summarizes activities of the } \\
\text { International Whaling Commission. }\end{array}$ \\
\hline $\begin{array}{l}\text { Ivashchenko } \\
\text { et al. }\end{array}$ & 2003 & Russia & Impacts & Gray whale & $\begin{array}{l}\text { This paper discusses the reactions of western gray } \\
\text { whales to seismic surveys. }\end{array}$ \\
\hline Jamison & 2001 & $\begin{array}{l}\text { Bering Sea, Gulf } \\
\text { of Alaska }\end{array}$ & Ecology & Harbor seal & $\begin{array}{l}\text { Scat and stomach contents were analyzed in order to } \\
\text { provide data on the diet of harbor seals. Regional } \\
\text { differences in diet were noted. }\end{array}$ \\
\hline Jamison et al. & 2001 & Bristol Bay & Population & Harbor seal & $\begin{array}{l}\text { Harbor seals were surveyed in Nunvak Bay and } \\
\text { analyzed with respect to time, weather, and sea } \\
\text { conditions. Trends were compared with those in other } \\
\text { populations in Alaska. }\end{array}$ \\
\hline
\end{tabular}


Table 4 (Cont.)

\begin{tabular}{|c|c|c|c|c|c|}
\hline Authors & Date & Location & Topic & Species & Document Content \\
\hline Jay et al. & 1998 & Bristol Bay & Impacts & Pacific walrus & $\begin{array}{l}\text { Responses of Pacific walruses to disturbance during } \\
\text { capture and handling activities associated with tagging } \\
\text { were measured at a haulout location at Cape Pierce. }\end{array}$ \\
\hline Kasuya & 2002 & General & General & Beaked whales & $\begin{array}{l}\text { A general description of the natural history and biology } \\
\text { of beaked whales. }\end{array}$ \\
\hline Kelly et al. & 1999 & Bering Sea & Population & Pacific walrus & $\begin{array}{l}\text { This paper discusses evidence of a declining } \\
\text { population of the Pacific walrus. }\end{array}$ \\
\hline Kim et al. & 1996 & Alaska & Impacts & Steller sea lion & $\begin{array}{l}\text { This paper presents results of research on the specific } \\
\text { accumulation and distribution of butylin compounds in } \\
\text { organs and tissues of the Steller sea lion. Comparisons } \\
\text { with organochlorine accumulation are made. }\end{array}$ \\
\hline Krahn et al. & 1997 & Alaska & Impacts & Seals & $\begin{array}{l}\text { Organochlorine contaminants in the blubber of four } \\
\text { seal species were discussed in terms of integrated } \\
\text { biomonitoring and specimen banking. }\end{array}$ \\
\hline Krahn et al. & 1999 & Alaska & Impacts & Beluga whale & $\begin{array}{l}\text { Concentrations and patterns of persistent } \\
\text { organochlorine contaminants were measured in three } \\
\text { Alaska stocks of beluga whales. }\end{array}$ \\
\hline Krahn et al. & 2001 & North Pacific & Impacts & Gray whale & $\begin{array}{l}\text { Organochlorine contaminant concentrations and lipid } \\
\text { profiles in the eastern North Pacific gray whale were } \\
\text { measured. }\end{array}$ \\
\hline $\begin{array}{l}\text { Kucey and } \\
\text { Trites }\end{array}$ & 2006 & General & Impacts & Sea lions & $\begin{array}{l}\text { This paper provides a review of the potential effects of } \\
\text { disturbance on sea lions, including both response and } \\
\text { recovery. }\end{array}$ \\
\hline Le Boeuf et al. & 2000 & $\begin{array}{l}\text { Bering Sea, } \\
\text { Pacific }\end{array}$ & Ecology & Gray whale & $\begin{array}{l}\text { This paper evaluates the starvation hypothesis, among } \\
\text { others, to explain high gray whale mortality. Declining } \\
\text { amphipod populations in the Bering Sea are } \\
\text { implicated. }\end{array}$ \\
\hline LeDuc et al. & 2000 & North Pacific & Population & North Pacific right whale & $\begin{array}{l}\text { This report discusses the progress of research on the } \\
\text { eastern North Pacific right whale during July } 1999 .\end{array}$ \\
\hline LeDuc et al. & 2001 & $\begin{array}{l}\text { Bering Sea, } \\
\text { Bristol Bay }\end{array}$ & Population & North Pacific right whale & $\begin{array}{l}\text { This note discusses surveys for right whales in the } \\
\text { southeastern Bering Sea. }\end{array}$ \\
\hline
\end{tabular}


Table 4 (Cont.)

\begin{tabular}{|c|c|c|c|c|c|}
\hline Authors & Date & Location & Topic & Species & Document Content \\
\hline LeDuc et al. & 2002 & North Pacific & Population & Gray whale & $\begin{array}{l}\text { This paper discusses genetic differences between } \\
\text { western and eastern North Pacific gray whale } \\
\text { populations. }\end{array}$ \\
\hline Lee et al. & 1996 & $\begin{array}{l}\text { Bering Sea, } \\
\text { Alaska }\end{array}$ & Impacts & Steller sea lion & $\begin{array}{l}\text { This paper discusses persistent organochlorines in } \\
\text { Steller sea lions in Alaska, including the Bering Sea, } \\
\text { from } 1976 \text { to } 1981 \text {. }\end{array}$ \\
\hline Lesage et al. & 1999 & $\begin{array}{l}\text { St. Lawrence } \\
\text { River }\end{array}$ & Impacts & Beluga whale & $\begin{array}{l}\text { This report presents observations on the behavior and } \\
\text { primarily vocalizations of beluga whales when in the } \\
\text { presence of noise from a ferry and a small boat. }\end{array}$ \\
\hline $\begin{array}{l}\text { Loughlin and } \\
\text { Yorke }\end{array}$ & 2000 & $\begin{array}{l}\text { Aleutian Islands, } \\
\text { Gulf of Alaska }\end{array}$ & $\begin{array}{l}\text { Population, } \\
\text { impacts }\end{array}$ & Steller sea lion & $\begin{array}{l}\text { This paper examines sources of mortality for the } \\
\text { western population of Steller sea lion that account for } \\
\text { decline of the population. Mortality of sea lions is } \\
\text { estimated for subsistence harvest, incidental to fishing, } \\
\text { illegal shooting, research, and predation by sharks and } \\
\text { killer whales. }\end{array}$ \\
\hline Lowry et al. & 1998 & $\begin{array}{l}\text { Bering Sea, } \\
\text { Chukchi Sea }\end{array}$ & Population & Spotted seal & $\begin{array}{l}\text { This paper monitored the movements and behavior of } \\
\text { satellite-tagged spotted seals caught in Kasegaluk } \\
\text { Lagoon in the Chukchi Sea. Movements and } \\
\text { proportion of time spent at haulouts or at sea were } \\
\text { monitored for } 12 \text { individuals. Seals range as far south } \\
\text { as the Bering Sea sites of Providenya Bay on Chukchi } \\
\text { Peninsula and Golovin Bay on the Seward Peninsula. }\end{array}$ \\
\hline Lowry et al. & $2000 \mathrm{a}$ & Bering Sea & Distribution & Spotted seal & $\begin{array}{l}\text { This paper examines habitat use and selection by } \\
\text { spotted seals in both Alaskan and Russian waters of the } \\
\text { Bering Sea. Seals were fitted with satellite-linked tags } \\
\text { and followed for August to June during several years. }\end{array}$ \\
\hline Lowry et al. & $2000 b$ & Bering Sea & Ecology & $\begin{array}{l}\text { Spotted seal, bearded seal, } \\
\text { ringed seal, Pacific walrus, } \\
\text { bowhead whale, beluga whale }\end{array}$ & $\begin{array}{l}\text { Discusses the relationship of marine mammals to sea } \\
\text { ice and evaluates potential changes in habitat, food } \\
\text { availability, and interspecies relationships due to } \\
\text { changes in sea ice. }\end{array}$ \\
\hline Maldini et al. & 2005 & Alaska & Population & Northern sea otter & $\begin{array}{l}\text { This report presents papers from a workshop } \\
\text { addressing the decline of the southwestern Alaska sea } \\
\text { otter population. }\end{array}$ \\
\hline
\end{tabular}


Table 4 (Cont.)

\begin{tabular}{|c|c|c|c|c|c|}
\hline Authors & Date & Location & Topic & Species & Document Content \\
\hline $\begin{array}{l}\text { Marine } \\
\text { Mammal } \\
\text { Commission }\end{array}$ & 2001 & General & $\begin{array}{l}\text { Regulation, } \\
\text { impacts }\end{array}$ & $\begin{array}{l}\text { North Pacific right whale, gray } \\
\text { whale, Steller sea lion, Pacific } \\
\text { walrus, harbor seal, northern sea } \\
\text { otter }\end{array}$ & $\begin{array}{l}\text { This report addresses the regulation, conservation, } \\
\text { management, status, and human impacts to marine } \\
\text { mammals listed as threatened and endangered under } \\
\text { the ESA or depleted under the MMPA. }\end{array}$ \\
\hline $\begin{array}{l}\text { Marine } \\
\text { Mammal } \\
\text { Commission }\end{array}$ & 2002 & General & $\begin{array}{l}\text { Regulation, } \\
\text { impacts }\end{array}$ & $\begin{array}{l}\text { North Pacific right whale, gray } \\
\text { whale, Steller sea lion, Pacific } \\
\text { walrus, harbor seal, northern sea } \\
\text { otter, humpback whale, killer } \\
\text { whale }\end{array}$ & $\begin{array}{l}\text { This report addresses the regulation, conservation, } \\
\text { management, status, and human impacts to marine } \\
\text { mammals listed as threatened and endangered under } \\
\text { the ESA or depleted under the MMPA. }\end{array}$ \\
\hline Marine & 2003 & General & Regulation, & North Pacific right whale, gray & This report addresses the regulation, conservation, \\
\hline
\end{tabular}

\section{Mammal \\ Commission}

Marine

Mammal

Commission

Marine

Mammal

Commission

Marine

Mammal

Commission

Matkin et al.
2004

General

2005

General

2006

General

ral

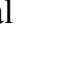

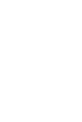

\section{impacts}

whale, Steller right whale, gray walrus, harbor seal, northern sea otter, humpback whale, killer whale

Regulation, Killer whale, northern sea otter, impacts beaked whales

Regulation, North Pacific right whale, impacts

\section{beaked whales}

Regulation, impacts

North Pacific right whale, killer whale, ice seals, harbor seal, Steller sea lion, northern fur seal, northern sea otter

Steller sea lion, killer whale management, status, and human impacts to marine mammals listed as threatened and endangered under the ESA or depleted under the MMPA.

This report addresses the regulation, conservation, management, status, and human impacts to marine mammals listed as threatened and endangered under the ESA or depleted under the MMPA.

This report addresses the regulation, conservation, management, status, and human impacts to marine mammals listed as threatened and endangered under the ESA or depleted under the MMPA.

This report addresses the regulation, conservation, management, status, and human impacts to marine mammals listed as threatened and endangered under the ESA or depleted under the MMPA. This edition gives special attention to Alaska marine ecosystems.

This paper estimates the predation of killer whales on Steller sea lions. It examines whether diet or predation contributes to the continuing decline and lack of recovery of sea lions, and concludes that predation may be an important source of mortality, but that better data are needed to quantify the extent to which predation contributes to the lack of recovery. 
Table 4 (Cont.)

\begin{tabular}{|c|c|c|c|c|c|}
\hline Authors & Date & Location & Topic & Species & Document Content \\
\hline $\begin{array}{l}\text { McDonald and } \\
\text { Moore }\end{array}$ & 2002 & Bristol Bay & Population & $\begin{array}{l}\text { North Pacific right whale, fin } \\
\text { whale, killer whale, sperm whale }\end{array}$ & $\begin{array}{l}\text { Calls from North Pacific right whales were recorded } \\
\text { during visual and acoustic surveys in Bristol Bay north } \\
\text { of the Aleutian Peninsula in July } 1999 \text {. Acoustic } \\
\text { detections numbered 26, and } 511 \text { calls were detected. } \\
\text { Calls were also detected from fin whales, killer whales } \\
\text { and a sperm whale. }\end{array}$ \\
\hline $\begin{array}{l}\text { Merrick and } \\
\text { Calkins }\end{array}$ & 1996 & Gulf of Alaska & Ecology & Steller sea lion & $\begin{array}{l}\text { This paper discusses the importance of juvenile } \\
\text { walleye pollock in the diet of Gulf of Alaska Steller } \\
\text { sea lions. }\end{array}$ \\
\hline Merrick et al. & 1997 & Alaska & Ecology & Steller sea lion & $\begin{array}{l}\text { Investigates the hypothesis that diet is related to the } \\
\text { decline of the Steller sea lion. }\end{array}$ \\
\hline MMS & $2006 a$ & $\begin{array}{l}\text { Beaufort Sea, } \\
\text { Chukchi Sea }\end{array}$ & Impacts & $\begin{array}{l}\text { Bowhead whale, fin whale, } \\
\text { humpback whale }\end{array}$ & $\begin{array}{l}\text { This evaluation of the potential effect of oil and gas } \\
\text { leasing in the Beaufort Sea and Chukchi Sea includes } \\
\text { the topics of acoustic effects, harassment, oil spill } \\
\text { effects, and development activities. The species } \\
\text { considered include bowhead whales, fin whales, and } \\
\text { humpback whales. The report also reviews the } \\
\text { literature on distribution, life history, ecology, and } \\
\text { human interactions for the species. }\end{array}$ \\
\hline MMS & $2006 b$ & Bering Sea & Population & Pacific walrus & $\begin{array}{l}\text { This report presents a final study plan for estimating } \\
\text { the size of the Pacific walrus population. The study } \\
\text { will include aerial photography, infrared imaging, and } \\
\text { satellite tagging of both western and eastern Bering } \\
\text { Sea populations. }\end{array}$ \\
\hline Moore & 2000 & Bering Sea & Population & Whales & $\begin{array}{l}\text { This paper discusses estimates of baleen whale } \\
\text { abundance on the central Bering Sea shelf in } 1999 \text {. }\end{array}$ \\
\hline Moore & 2002 & Bering Sea & Population & Cetaceans & $\begin{array}{l}\text { The use of acoustics in detecting cetaceans is } \\
\text { discussed. }\end{array}$ \\
\hline Moore & 2005 & General & Impacts & Marine mammals & $\begin{array}{l}\text { This book chapter discusses the potential effects of } \\
\text { long-term environmental change on marine mammals. }\end{array}$ \\
\hline Moore & 2006 & Bering Sea & Distribution & $\begin{array}{l}\text { Fin whale, humpback whale, } \\
\text { gray whale, North Pacific right } \\
\text { whale }\end{array}$ & $\begin{array}{l}\text { General overview of cetacean distribution and } \\
\text { abundance in the Bering Sea. }\end{array}$ \\
\hline
\end{tabular}


Table 4 (Cont.)

\begin{tabular}{|c|c|c|c|c|c|}
\hline Authors & Date & Location & Topic & Species & Document Content \\
\hline $\begin{array}{l}\text { Moore and } \\
\text { Clarke }\end{array}$ & 2002 & General & Impacts & Gray whale & $\begin{array}{l}\text { This paper reviews information on the effects of } \\
\text { human activities on the western gray whale. Offshore } \\
\text { oil and gas drilling, commercial fishing and vessel } \\
\text { traffic, and whale watching and scientific research are } \\
\text { discussed. }\end{array}$ \\
\hline Moore et al. & 2000 & Bering Sea & Population & Whale & $\begin{array}{l}\text { This paper discusses baleen whale abundance and } \\
\text { associations with prey on the central Bering Sea shelf. }\end{array}$ \\
\hline Moore et al. & 2001 & General & Population & Gray whale & $\begin{array}{l}\text { Abundance of gray whales is discussed with respect to } \\
\text { carrying capacity. }\end{array}$ \\
\hline Moore et al. & 2002 & Bering Sea & Populations & Whales, porpoises & $\begin{array}{l}\text { Discusses associations of the distribution of cetaceans } \\
\text { in the central and southeastern Bering Sea with } \\
\text { bathymetry and prey. }\end{array}$ \\
\hline Moulton et al. & 2003 & Beaufort Sea & Impacts & Ringed seal & $\begin{array}{l}\text { Discusses the effects of offshore oil development with } \\
\text { abundance and distribution of ringed seals in the } \\
\text { Beaufort Sea. }\end{array}$ \\
\hline $\begin{array}{l}\text { National } \\
\text { Marine } \\
\text { Mammals } \\
\text { Laboratory }\end{array}$ & 2006 & Alaska & $\begin{array}{l}\text { Multiple } \\
\text { topics }\end{array}$ & Marine mammals & $\begin{array}{l}\text { National Marine Mammal Laboratory library website } \\
\text { contains an extensive collection of marine mammal } \\
\text { literature. }\end{array}$ \\
\hline NMFS & 2001 & $\begin{array}{l}\text { Bering Sea, } \\
\text { Aleutian Islands }\end{array}$ & Impacts & Steller sea lion & $\begin{array}{l}\text { This report provides a detailed discussion of past and } \\
\text { potential effects of fishing and other human activities } \\
\text { on Steller sea lions. It discusses fishing, status and } \\
\text { management, life history and ecology, and cumulative } \\
\text { effects, and contains an extensive bibliography. }\end{array}$ \\
\hline NMFS & 2003 & Alaska & Impacts & Steller sea lion & $\begin{array}{l}\text { This report supplements the } 2001 \text { Biological Opinion } \\
\text { on the pollock, cod, and mackerel fisheries off Alaska, } \\
\text { updates the status of the Steller sea lion, and } \\
\text { summarizes Steller sea lion conservation measures. } \\
\text { Changes in the spatial and temporal distribution and } \\
\text { the possible effects of groundfish fisheries on the prey } \\
\text { field for sea lions are discussed. }\end{array}$ \\
\hline
\end{tabular}


Table 4 (Cont.)

\begin{tabular}{|c|c|c|c|c|c|}
\hline Authors & Date & Location & Topic & Species & Document Content \\
\hline NMFS & 2005 & United States & General & Northern right whale & $\begin{array}{l}\text { This presentation at a scoping meeting discusses the } \\
\text { EIS on Northern right whale research planned to be } \\
\text { completed in August } 1997 .\end{array}$ \\
\hline NMFS & $2006 \mathrm{a}$ & Worldwide & $\begin{array}{l}\text { Threatened } \\
\text { and } \\
\text { endangered } \\
\text { species }\end{array}$ & Fin whale & Draft recovery plan for the fin whale. \\
\hline NMFS & $2006 b$ & Alaska & $\begin{array}{l}\text { Threatened } \\
\text { and } \\
\text { endangered } \\
\text { species }\end{array}$ & North Pacific right whale & $\begin{array}{l}\text { Proposed rule to list the North Pacific right whale as } \\
\text { endangered and designate critical habitat in the Gulf of } \\
\text { Alaska and Bering Sea. }\end{array}$ \\
\hline NMFS & $2006 c$ & Alaska & Regulation & Steller sea lion & $\begin{array}{l}\text { This map shows designated critical habitat for the } \\
\text { Steller sea lion. }\end{array}$ \\
\hline NOAA & $2006 \mathrm{a}$ & Worldwide & $\begin{array}{l}\text { Population, } \\
\text { impacts }\end{array}$ & Fin whale & $\begin{array}{l}\text { This report is a draft recovery plan for the Antarctic, } \\
\text { Atlantic, and North Pacific populations of the fin } \\
\text { whale. Taxonomy, species description, population } \\
\text { structure, zoogeography, life history, and ecology are } \\
\text { described. The report discusses all sources of threats, } \\
\text { both human and natural, and defines a recovery } \\
\text { program. }\end{array}$ \\
\hline NOAA & $2006 b$ & Alaska & Regulation & Steller sea lion & $\begin{array}{l}\text { This draft recovery plan for the western population of } \\
\text { the Steller sea lion describes the species, its population } \\
\text { structure, life history, and ecology. The report } \\
\text { describes all sources of threats, both human and } \\
\text { natural, and defines a recovery program. }\end{array}$ \\
\hline NOAA & $2006 \mathrm{c}$ & Alaska & $\begin{array}{l}\text { Threatened } \\
\text { and } \\
\text { endangered } \\
\text { species }\end{array}$ & Marine mammals & $\begin{array}{l}\text { NOAA website with information on latest status and } \\
\text { activities related to protected species and their habitats, } \\
\text { such as new fisheries regulations for protection of } \\
\text { Steller sea lion critical habitat. }\end{array}$ \\
\hline NOAA & $2006 d$ & Alaska & $\begin{array}{l}\text { Critical } \\
\text { habitat }\end{array}$ & Steller sea lion & $\begin{array}{l}\text { Website providing information on Steller sea lion } \\
\text { critical habitat and no-entry zones. }\end{array}$ \\
\hline
\end{tabular}




\section{Table 4 (Cont.)}

\begin{tabular}{|c|c|c|c|c|c|}
\hline Authors & Date & Location & Topic & Species & Document Content \\
\hline $\begin{array}{l}\text { Nordeen and } \\
\text { Lien }\end{array}$ & 2001 & General & Impacts & Baleen whales & $\begin{array}{l}\text { This report discusses the effects of high-amplitude } \\
\text { acoustics on the distribution, abundance, and behavior } \\
\text { of baleen whales. }\end{array}$ \\
\hline Pauly et al. & 1998 & World & Ecology & $\begin{array}{l}\text { Pinnipeds, cetaceans, and } \\
\text { northern se otter }\end{array}$ & $\begin{array}{l}\text { Standardized diet compositions were derived for } 97 \\
\text { species of marine mammals from published accounts } \\
\text { of stomach contents, as well as from morphological, } \\
\text { behavioral, and other information. Diet was } \\
\text { apportioned among eight categories of prey types } \\
\text { (benthic invertebrates, large zooplankton, small squids, } \\
\text { large squids, small pelagic fishes, mesopelagic fishes, } \\
\text { miscellaneous fishes, and higher invertebrates). } \\
\text { Trophic levels were estimated for each species of } \\
\text { marine mammals and compared with published } \\
\text { estimates derived using stable isotope ratios. }\end{array}$ \\
\hline $\begin{array}{l}\text { Perryman and } \\
\text { Lynn }\end{array}$ & 2002 & Pacific & Population & Gray whale & $\begin{array}{l}\text { This paper evaluated the nutritive condition and } \\
\text { reproductive status of migrating gray whales using } \\
\text { photogrammetric data. }\end{array}$ \\
\hline $\begin{array}{l}\text { Poole and } \\
\text { Givens }\end{array}$ & 2001 & $\begin{array}{l}\text { Bering Sea, } \\
\text { Chukchi Sea, } \\
\text { Beaufort Sea }\end{array}$ & Population & Bowhead whale & $\begin{array}{l}\text { Assessment of the Bering-Chukchi-Beaufort Seas } \\
\text { population of bowhead whales. }\end{array}$ \\
\hline $\begin{array}{l}\text { Punt and } \\
\text { Butterworth }\end{array}$ & 1996 & $\begin{array}{l}\text { Bering Sea, } \\
\text { Chukchi Sea, } \\
\text { Beaufort Sea }\end{array}$ & Population & Bowhead whale & $\begin{array}{l}\text { Discusses a Bayesian approach to assessing of the } \\
\text { Bering-Chukchi-Beaufort Seas population of bowhead } \\
\text { whales. }\end{array}$ \\
\hline $\begin{array}{l}\text { Punt and } \\
\text { Butterworth }\end{array}$ & 1997 & $\begin{array}{l}\text { Bering Sea, } \\
\text { Chukchi Sea, } \\
\text { Beaufort Sea }\end{array}$ & Population & Bowhead whale & $\begin{array}{l}\text { Discusses maximum likelihood and Bayesian } \\
\text { approaches to assessing bowhead whale populations in } \\
\text { the Bering-Chukchi-Beaufort Seas. }\end{array}$ \\
\hline $\begin{array}{l}\text { Punt and } \\
\text { Butterworth }\end{array}$ & 1999 & $\begin{array}{l}\text { Bering Sea, } \\
\text { Chukchi Sea, } \\
\text { Beaufort Sea }\end{array}$ & Population & Bowhead whale & $\begin{array}{l}\text { Presents a Bayesian approach for modeling bowhead } \\
\text { whale populations. }\end{array}$ \\
\hline $\begin{array}{l}\text { Punt and } \\
\text { Butterworth }\end{array}$ & 2000 & $\begin{array}{l}\text { Bering Sea, } \\
\text { Chukchi Sea, } \\
\text { Beaufort Sea }\end{array}$ & Population & Bowhead whale & $\begin{array}{l}\text { Discusses differences in maximum likelihood and } \\
\text { Bayesian approaches to assessing bowhead whale } \\
\text { populations. }\end{array}$ \\
\hline
\end{tabular}


Table 4 (Cont.)

\begin{tabular}{|c|c|c|c|c|c|}
\hline Authors & Date & Location & Topic & Species & Document Content \\
\hline $\begin{array}{l}\text { Punt and } \\
\text { Butterworth }\end{array}$ & 2002 & $\begin{array}{l}\text { Bering Sea, } \\
\text { Chukchi Sea, } \\
\text { Beaufort Sea }\end{array}$ & Population & Gray whale & $\begin{array}{l}\text { Discusses assumptions used in assessing the status of } \\
\text { gray whale stocks. }\end{array}$ \\
\hline Punt et al. & 1997 & $\begin{array}{l}\text { Bering Sea, } \\
\text { Chukchi Sea, } \\
\text { Beaufort Sea }\end{array}$ & Population & Bowhead whale & $\begin{array}{l}\text { Comparison of strike limit algorithms for the Bering- } \\
\text { Chukchi-Beaufort Seas stock of bowhead whales. }\end{array}$ \\
\hline $\begin{array}{l}\text { Read and } \\
\text { Wade }\end{array}$ & 2000 & $\begin{array}{l}\text { Bering Sea, Gulf } \\
\text { of Alaska }\end{array}$ & $\begin{array}{l}\text { Population, } \\
\text { impacts }\end{array}$ & Steller sea lion, harbor seal & $\begin{array}{l}\text { This report lists marine mammals for which the take } \\
\text { exceeds the potential biological removal level set under } \\
\text { the MMPA. Steller sea lion and Gulf of Alaska harbor } \\
\text { seals are listed. }\end{array}$ \\
\hline Ream et al. & 2005 & $\begin{array}{l}\text { Bering Sea, } \\
\text { North Pacific }\end{array}$ & $\begin{array}{l}\text { Population, } \\
\text { impacts }\end{array}$ & Northern fur seal & $\begin{array}{l}\text { This paper reports results of monitoring the movements } \\
\text { of } 13 \text { female northern fur seals tagged at St. Paul Island } \\
\text { during November } 2002 \text {. Seals migrated through the } \\
\text { Bering Sea through Unimak into the North Pacific as } \\
\text { far as the California coast and oceanic transition zone. } \\
\text { Two seals were tracked until they returned to St. Paul } \\
\text { Island after journeys of more than } 9,000 \mathrm{~km} \text {. Dive } \\
\text { characteristics of fur seals, relationship to } \\
\text { oceanographic features, and detailed diet data for fur } \\
\text { seals at sea are also presented. }\end{array}$ \\
\hline Reeves et al. & 1998 & $\begin{array}{l}\text { Atlantic and } \\
\text { North Pacific } \\
\text { Ocean }\end{array}$ & $\begin{array}{l}\text { Regulation, } \\
\text { impacts }\end{array}$ & Fin whale, sei whale & $\begin{array}{l}\text { This report is a draft recovery plan for the Atlantic and } \\
\text { North Pacific populations of the fin whale and the } \\
\text { North Pacific population of the sei whale. It describes } \\
\text { taxonomy, species description, population structure, } \\
\text { zoogeography, life history, and ecology. The report } \\
\text { discusses all sources of threats, both human and } \\
\text { natural, and defines a recovery program. }\end{array}$ \\
\hline Richardson & 1996 & Beaufort Sea & Impacts & Bowhead whale & $\begin{array}{l}\text { This paper reports the response of bowhead whales to } \\
\text { disturbances from vessels, dredging, and drilling } \\
\text { activities. This paper is followed by other papers on } \\
\text { acoustics and response of whales. }\end{array}$ \\
\hline
\end{tabular}


Table 4 (Cont.)

\begin{tabular}{|c|c|c|c|c|c|}
\hline Authors & Date & Location & Topic & Species & Document Content \\
\hline Rugh et al. & 1997 & Alaska & Distribution & Spotted seal & This paper discusses the spotted seal in Alaska. \\
\hline Rugh et al. & 1999 & North Pacific & $\begin{array}{l}\text { Regulation, } \\
\text { impacts }\end{array}$ & Gray whale & $\begin{array}{l}\text { This document reviews the status of the eastern } \\
\text { population of gray whale } 5 \text { years after removal from } \\
\text { the list of endangered and threatened wildlife and } \\
\text { plants in } 1994 \text {. It describes abundance, distribution, } \\
\text { population trends, reproduction, habitat use, and } \\
\text { anthropogenic concerns. }\end{array}$ \\
\hline Rugh et al. & 2001 & Pacific & Distribution & Gray whale & $\begin{array}{l}\text { This paper discusses the timing of the western gray } \\
\text { whale southbound migration. }\end{array}$ \\
\hline Schell & 2000 & Bering Sea & Ecology & Bowhead whale & $\begin{array}{l}\text { Isotope ratios in baleen from bowhead whales were } \\
\text { used to estimate the marine productivity and the } \\
\text { carrying capacity of the Bering Sea ecosystem. }\end{array}$ \\
\hline Scribner et al. & 1997 & General & Populations & Northern sea otter & $\begin{array}{l}\text { A review of genetic studies was used to differentiate } \\
\text { populations of sea otters. }\end{array}$ \\
\hline $\begin{array}{l}\text { Seagars and } \\
\text { Garlich-Miller }\end{array}$ & 2001 & Bering Sea & $\begin{array}{l}\text { Ecology, } \\
\text { impacts }\end{array}$ & Pacific walrus & $\begin{array}{l}\text { This study reported analyses of organochlorine } \\
\text { compounds and aliphatic hydrocarbons in Pacific } \\
\text { walrus blubber. }\end{array}$ \\
\hline Sheffield et al. & 2001 & Bering Sea & Ecology & Pacific walrus & $\begin{array}{l}\text { Controlled digestion studies were used to determine } \\
\text { differential digestion rates of walrus prey. The } \\
\text { objective was to evaluate biases in diet data based on } \\
\text { stomach contents. }\end{array}$ \\
\hline $\begin{array}{l}\text { Shelden and } \\
\text { Rugh }\end{array}$ & 2002 & Worldwide & Regulation & Bowhead whale & $\begin{array}{l}\text { This report describes the historic and current status of } \\
\text { the bowhead whale. The study supports decision } \\
\text { making on bowhead whale management under the } \\
\text { ESA. }\end{array}$ \\
\hline Shelden et al. & 2001 & General & Regulation & Bowhead whale & $\begin{array}{l}\text { This paper discusses considerations involved in } \\
\text { reviewing the status of marine mammals proposed for } \\
\text { listing under the ESA. The bowhead whale is used as a } \\
\text { case study. }\end{array}$ \\
\hline Shelden et al. & 2005 & $\begin{array}{l}\text { Bering Sea, Gulf } \\
\text { of Alaska }\end{array}$ & Distribution & North Pacific right whale & $\begin{array}{l}\text { This paper uses siting data to evaluate historic and } \\
\text { current habitat use by North Pacific right whales. }\end{array}$ \\
\hline
\end{tabular}


Table 4 (Cont.)

\begin{tabular}{|c|c|c|c|c|c|}
\hline Authors & Date & Location & Topic & Species & Document Content \\
\hline Shelden et al. & 2006 & $\begin{array}{l}\text { Bering Sea, Gulf } \\
\text { of Alaska }\end{array}$ & Distribution & North Pacific right whale & $\begin{array}{l}\text { This presentation presents historic and recent data on } \\
\text { the distribution of North Pacific right whales in the } \\
\text { eastern north Pacific, with emphasis on the } \\
\text { southeastern Bering Sea and the Gulf of California. }\end{array}$ \\
\hline Simpkins et al. & 2003 & Bering Sea & Ecology & $\begin{array}{l}\text { Bearded seal, ringed seal, ribbon } \\
\text { seal, spotted seal, Pacific walrus }\end{array}$ & $\begin{array}{l}\text { Aerial surveys of ice-associated pinnipeds were } \\
\text { evaluated with respect to ice habitat type and benthic } \\
\text { community. }\end{array}$ \\
\hline Sinclair et al. & 2005 & $\begin{array}{l}\text { Bering Sea, Gulf } \\
\text { of Alaska }\end{array}$ & Distribution & $\begin{array}{l}\text { Steller sea lion, humpback } \\
\text { whale, minke whale, killer } \\
\text { whale, sperm whale }\end{array}$ & $\begin{array}{l}\text { Biophysical variables were analyzed with respect to } \\
\text { locations of Steller sea lions and cetaceans. The most } \\
\text { significant correlations were depth and proximity to the } \\
\text { nearest measured pass for Steller sea lions and all } \\
\text { cetaceans, respectively; frequencies of herring and } \\
\text { salmon in Steller sea lion diet with population trend; } \\
\text { fluorescence in the top } 50 \mathrm{~m} \text { with occurrence of } \\
\text { humpback, minke, and killer whales; and surface } \\
\text { temperature with occurrence of humpback, killer, and } \\
\text { sperm whales. }\end{array}$ \\
\hline Small & 2001 & Bristol Bay & Distribution & Harbor seal & $\begin{array}{l}\text { Seal haulouts were identified on the north side of the } \\
\text { Alaska Peninsula during 1998-1999. }\end{array}$ \\
\hline Small et al. & 2003 & $\begin{array}{l}\text { Bristol Bay, Gulf } \\
\text { of Alaska }\end{array}$ & Population & Harbor seal & $\begin{array}{l}\text { Trends in abundance of harbor seals were evaluated for } \\
\text { the years } 1983-2001 \text {. }\end{array}$ \\
\hline Smultea et al. & 1999 & Beaufort Sea & Impacts & Seals & $\begin{array}{l}\text { Reactions of seals to underwater playbacks of drilling } \\
\text { and icebreaker noise were observed. }\end{array}$ \\
\hline Strick et al. & 1997 & Aleutian Islands & Population & Steller sea lion & $\begin{array}{l}\text { Aerial and ship-based surveys of Steller sea lions were } \\
\text { conducted from southeast Alaska to the Aleutian } \\
\text { Islands in June and July } 1994 \text {. }\end{array}$ \\
\hline Taylor & 2003 & $\begin{array}{l}\text { Beaufort Sea, } \\
\text { Bering Sea, } \\
\text { Chukchi Sea }\end{array}$ & Population & Bowhead whale & $\begin{array}{l}\text { This paper discusses modeling that is related to the } \\
\text { issue of whether the Beaufort-Chukchi-Bering Sea } \\
\text { population of bowhead whales should be listed as } \\
\text { endangered. }\end{array}$ \\
\hline
\end{tabular}


Table 4 (Cont.)

\begin{tabular}{|c|c|c|c|c|c|}
\hline Authors & Date & Location & Topic & Species & Document Content \\
\hline $\begin{array}{l}\text { Trites and } \\
\text { Heise }\end{array}$ & 1996 & Gulf of Alaska & Ecology & Pinnipeds, cetaceans & $\begin{array}{l}\text { This report estimates the consumption of food by } 13 \\
\text { populations of marine mammals found in the Alaskan } \\
\text { Gyre of the Gulf of Alaska. The model of food } \\
\text { consumption is based on population numbers, mean } \\
\text { body weight, and gender. Prey composition is also } \\
\text { noted. }\end{array}$ \\
\hline Trites et al. & 2006 & World & $\begin{array}{l}\text { Ecology, } \\
\text { impacts, } \\
\text { population }\end{array}$ & Steller sea lion & $\begin{array}{l}\text { This report presents papers from a symposium on sea } \\
\text { lions of the world. The following topics are included: } \\
\text { physiological ecology, foraging ecology, population } \\
\text { ecology and dynamics, and conservation and } \\
\text { management. The following topics on the Steller sea } \\
\text { lion are included: contaminants, maternal behavior, } \\
\text { prey type, prey abundance, prey variability, diving and } \\
\text { feeding behavior, spatial dynamics, population trends, } \\
\text { management, and response to disturbance and noise. }\end{array}$ \\
\hline Tynan & 1999 & Bering Sea & Distribution & $\begin{array}{l}\text { Fin whale, sei whale, humpback } \\
\text { whale, minke whale, North } \\
\text { Pacific right whale }\end{array}$ & $\begin{array}{l}\text { Visual surveys during transects of the Bering Sea were } \\
\text { used to monitor the distribution of five whale species } \\
\text { during unusual oceanographic conditions associated } \\
\text { with El Niño in } 1997 \text {. Whale distribution was } \\
\text { associated with shifts in production plankton. }\end{array}$ \\
\hline UBC & 1999 & Bering Sea & Ecology & Marine mammals & $\begin{array}{l}\text { This report describes the application of mass balance } \\
\text { ecosystem models to the ecosystem of the Bering Sea in } \\
\text { order to compare results from } 1950 \text { with } 1980 \text {. The } \\
\text { results are interpreted with respect to changes in marine } \\
\text { mammal exploitation, changes of fisheries, and } \\
\text { ecosystem production. }\end{array}$ \\
\hline USGS & 2004 & $\begin{array}{l}\text { Bering Sea, } \\
\text { Chukchi Sea }\end{array}$ & Population & Pacific walrus & $\begin{array}{l}\text { The Pacific Walrus International Database is a } \\
\text { comprehensive set of Pacific walrus biological data } \\
\text { collected in the Bering and Chukchi Seas by several } \\
\text { participating organizations. Data categories include: } \\
\text { land and ice haulout counts, gender/age composition, } \\
\text { reproduction, mortality, harvest statistics, and } \\
\text { morphometry. }\end{array}$ \\
\hline
\end{tabular}


Table 4 (Cont.)

\begin{tabular}{|c|c|c|c|c|c|}
\hline Authors & Date & Location & Topic & Species & Document Content \\
\hline Wade & 1998 & Alaska & $\begin{array}{l}\text { Population, } \\
\text { impacts }\end{array}$ & Cetaceans, pinnipeds & $\begin{array}{l}\text { This paper discusses calculating limits to the allowable } \\
\text { human-caused mortality of cetaceans and pinnipeds. }\end{array}$ \\
\hline Wade & 2002 & $\begin{array}{l}\text { Alaska, Bering } \\
\text { Sea }\end{array}$ & Population & Gray whale & $\begin{array}{l}\text { Stock assessment for the eastern Pacific gray whale } \\
\text { using Bayesian analyses. }\end{array}$ \\
\hline Wade et al. & 2006 & Bering Sea & Distribution & North Pacific right whale & $\begin{array}{l}\text { Reports on the use of sonobuoys and satellite radio tags } \\
\text { to identify and track right whales in the Bering Sea, } \\
\text { and on results of photographic and genetic analyses of } \\
\text { some of these whales. }\end{array}$ \\
\hline Waite 1998 & 1998 & Alaska & Distribution & North Pacific right whale & $\begin{array}{l}\text { Paper discusses sighting of North Pacific right whales } \\
\text { off Alaska. }\end{array}$ \\
\hline Waite et al. & 2002 & Bering Sea & $\begin{array}{l}\text { Distribution, } \\
\text { population }\end{array}$ & Killer whale & $\begin{array}{l}\text { Reports on the distribution and abundance of killer } \\
\text { whales in the central and southeastern Bering Sea in } \\
1999 \text { and } 2000 .\end{array}$ \\
\hline Weller et al. & 2002 & Sea of Okhostk & Impacts & Western gray whale & $\begin{array}{l}\text { Study evaluated the effects of 3D seismic testing on the } \\
\text { distribution of gray whales on known feeding areas. } \\
\text { Results show a relationship between seismic survey } \\
\text { operations and an observed change in distribution of } \\
\text { whales. }\end{array}$ \\
\hline Wiggens et al. & 2004 & Bering Sea & Distribution & North Pacific right whale & $\begin{array}{l}\text { Waveguide propagation used to estimate range of } \\
\text { North Pacific right whales in the Bering Sea. }\end{array}$ \\
\hline $\begin{array}{l}\text { Winship and } \\
\text { Trites }\end{array}$ & 2006 & $\begin{array}{l}\text { Gulf of Alaska, } \\
\text { Aleutian Islands }\end{array}$ & Population & Steller sea lion & $\begin{array}{l}\text { Study used population viability analysis to estimate the } \\
\text { risk of the Steller sea lion becoming extirpated in } \\
\text { western Alaska. Results suggest that the overall predicted } \\
\text { risk of extirpation of Steller sea lions as a species in } \\
\text { western Alaska was low in the next } 100 \text { yr under all } \\
\text { scenarios explored. However, most subpopulations of } \\
\text { Steller sea lions had high probabilities of going extinct } \\
\text { within the next } 100 \text { years if population trends observed } \\
\text { during the } 1990 \text { s were to continue. }\end{array}$ \\
\hline Winship et al. & 2001 & $\begin{array}{l}\text { Gulf of Alaska, } \\
\text { Bering Sea }\end{array}$ & Growth & Steller sea lion & $\begin{array}{l}\text { Growth models (mass and length) were constructed for } \\
\text { male ( } 1 \text { year old), female ( } 1 \text { year old), and pregnant } \\
\text { female Steller sea lions shot on rookeries or haulouts, } \\
\text { or in coastal waters. }\end{array}$ \\
\hline
\end{tabular}


Table 4 (Cont.)

\begin{tabular}{|c|c|c|c|c|c|}
\hline Authors & Date & Location & Topic & Species & Document Content \\
\hline $\begin{array}{l}\text { Wolfe and } \\
\text { Mishler }\end{array}$ & 1996 & Alaska & Impacts & Harbor seal, Steller sea lion & $\begin{array}{l}\text { This report provides detailed information on the } \\
\text { subsistence take of harbor seals and Steller sea lions by } \\
\text { Alaska natives in the previous year. }\end{array}$ \\
\hline $\begin{array}{l}\text { Wolfe and } \\
\text { Hutchinson- } \\
\text { Scarbrough }\end{array}$ & 1999 & Alaska & Impacts & Harbor seal, Steller sea lion & $\begin{array}{l}\text { This report provides detailed information on the } \\
\text { subsistence take of harbor seals and Steller sea lions by } \\
\text { Alaska natives in the previous year. }\end{array}$ \\
\hline Wolfe et al. & 2002 & Alaska & Subsistence & Harbor seal, Steller sea lion & $\begin{array}{l}\text { This report provides detailed information on the } \\
\text { subsistence take of harbor seals and Steller sea lions by } \\
\text { Alaska natives in the previous year. }\end{array}$ \\
\hline Wolfe et al. & 2003 & Alaska & Impacts & Harbor seal, Steller sea lion & $\begin{array}{l}\text { This report provides detailed information on the } \\
\text { subsistence take of harbor seals and Steller sea lions by } \\
\text { Alaska native in the previous year. }\end{array}$ \\
\hline Wolfe et al. & 2004 & Alaska & Impacts & Harbor seal, Steller sea lion & $\begin{array}{l}\text { This report provides detailed information on the } \\
\text { subsistence take of harbor seals and Steller sea lions by } \\
\text { Alaska natives in the previous year. }\end{array}$ \\
\hline Wolfe et al. & 2005 & Alaska & Impacts & Harbor seal, Steller sea lion & $\begin{array}{l}\text { This report provides detailed information on the } \\
\text { subsistence take of harbor seals and Steller sea lions by } \\
\text { Alaska natives in the previous year. }\end{array}$ \\
\hline Zeh et al. & 2002 & Alaska & Population & Bowhead whale & $\begin{array}{l}\text { Annual survival probability of bowhead whales was } \\
\text { estimated using both Bayesian and maximum } \\
\text { likelihood implementations of Cormack and Jolly- } \\
\text { Seber models for capture-recapture estimation in open } \\
\text { populations and reduced-parameter generalizations of } \\
\text { these models. Aerial photographs of naturally marked } \\
\text { bowheads collected between } 1981 \text { and } 1998 \text { provided } \\
\text { the data. }\end{array}$ \\
\hline
\end{tabular}




\section{SOCIOECONOMICS AND SUBSISTENCE}

Presentations at the Planning Meeting included overviews of (1) community socioeconomics by Ed Glazier of Impact Assessment, Inc. (IAI) and (2) subsistence research by Brian Davis, formerly of the ADFG, Division of Subsistence. The presentations, which can be found in the Planning Meeting report, summarize available information and information needs on these topics relevant to an impact assessment of oil and gas development in the Basin.

Socioeconomic trends and current conditions have been summarized in a report prepared by IAI in preparation for the Planning Meeting (IAI 2007). ${ }^{3}$ The report provides an excellent overview of socioeconomics and subsistence activities for the communities adjacent to the North Aleutian Basin. It can be used as a source document for preparation of impact assessments for oil and gas development in the North Aleutian Basin. References from the report are included in Section 7.5.

Descriptive and quantitative information is presented in IAI (2007) for the following geographical regions in the vicinity of the North Aleutian Basin:

- Aleutian East Borough and Unalaska/Dutch Harbor, including the communities of Akutan, Cold Bay, False Pass, King Cove, Nelson Lagoon, Sand Point, and Unalaska/Dutch Harbor;

- Bristol Bay Region, including Goodnews Bay, King Salmon, Naknek, South Naknek, Togiak, Manokotak, New Stuyahok, Clark's Point, and Dillingham;

- Lake and Peninsula Borough, including Newhalen, Pilot Point, Port Heiden, Egegik, Chignik, Chignik Lake, Chignik Lagoon, Ivanoff Bay, Perryville, Port Moller, and Pauloff Harbor.

For each of these regions, a socioeconomic overview is provided in the IAI report that describes population trends, demographic conditions, patterns of out-migration, employment, seasonal workers, nonresident employment, income, and the dominant economic activities in the region, including commercial fisheries, sport fisheries, and subsistence. Location, history, conditions, and trends are provided for the communities in each region.

The following is a brief overview of socioeconomic and subsistence trends and conditions in the communities of the North Aleutian Basin as presented in IAI (2007).

The economy of communities in the North Aleutian Basin region is based primarily on commercial fisheries and associated services, including harvest, processing, and distribution of seafood. Salmon fisheries are most important in communities in the northern portion of the Basin, while groundfish, crab, and salmon fisheries are prevalent in the southern portion.

Detrimental socioeconomic effects have occurred in communities throughout the North Aleutian Basin as a result of recent downturns in the salmon fishery and other commercial

\footnotetext{
${ }^{3}$ The IAI 2007 report is available at: www.mms.gov/alaska/reports/2007rpts/akpubs07.htm.
} 
fisheries. Many households in the region were living in conditions of poverty at the time of the year 2000 Census. There are few employment alternatives to fishing and associated industries in the Basin. Sport fish guiding is a possible alternative, but the decline in salmon populations has resulted in an apparent decrease in demand. Government employment opportunities are limited, but do provide important sources of income for some individuals.

Subsistence fishing and hunting are critically important to many residents of the Basin, both as a source of food and for the maintenance of cultural traditions. While many persons of all ethnic groups engage in hunting and fishing activities, the majority of participants are Alaska natives who continue centuries-long traditions of gathering wild foods. Food-sharing and trade are common throughout the area and buffer participants from changes in the modern economy. However, hunting and fishing activities have come to rely, at least in part, on the availability of cash. Generations of Alaska natives have supported their hunting and fishing activities with money obtained through commercial fishing, and, consequently, problems in commercial fisheries can have cascading effects for subsistence practitioners.

Options for employment and income are limited in the North Aleutian Basin area. In addition, recent warm winters have hindered transportation and subsistence activities throughout much of the region. Residents throughout the Basin are confronting a range of challenges at the start of the 21 st century. A meaningful assessment of economic opportunities in this region needs to examine both traditional interests and the social and economic challenges that are characteristic of rural Alaska today. 


\section{BIBLIOGRAPHY}

\subsection{OCEANOGRAPHY AND ECOSYSTEMS}

Abromaitis, G.E. 2000. A Retrospective Assessment of Primary Productivity on the Bering and Chukchi Sea Shelves Using Stable Isotope Ratios in Seabirds. M.S. thesis, University of Alaska, Fairbanks.

Alexander, V. 1999. "Interdisciplinary Studies of the Bering Sea." pp. 683-686 in T.R. Loughlin and K. Ohtani (eds.), Dynamics of the Bering Sea. University of Alaska Sea Grant, AK-SG-9903, Fairbanks.

AMAP. See Arctic Monitoring and Assessment Programme.

Arctic Monitoring and Assessment Programme. 1998a. "Climate Change, Ozone, and Ultraviolet Radiation." In Arctic Monitoring and Assessment Programme: Arctic Pollution Issues. Arctic Monitoring and Assessment Programme, Oslo, Norway.

Arctic Monitoring and Assessment Programme. 1998b. "The Influence of Physical and Chemical Processes on Contaminant Transport into and within the Arctic." In Arctic Monitoring and Assessment Programme: Arctic Pollution Issues. Arctic Monitoring and Assessment Programme, Oslo, Norway.

Arctic Monitoring and Assessment Programme. 1998c. "Physical/Geographical Characteristics of the Arctic." In Arctic Monitoring and Assessment Programme: Arctic Pollution Issues. Arctic Monitoring and Assessment Programme, Oslo, Norway.

Ambrose, W.G., L.M. Clough, R.R. Tilney, and L. Beer. 2001. "Role of Echinoderms in Benthic Remineralization in the Chukchi Sea." Marine Biology 139(5):937-949.

Arzhanova, N.V., V.L. Zubarevich, and V.V. Sapozhnikov. 1996. "Seasonal Variability of Nutrient Stocks in the Euphotic Zone and Assessment of Primary Production in the Bering Sea." pp. 162-179 in B.N. Kotenev and V.V. Sapozhnikov (eds.), Complex Studies of the Bering Sea Ecosystem. VNIRO, Moscow, Russia.

Bailey, K.M. 2000. "Shifting Control of Recruitment of Walleye Pollock Theragra chalcogramma after a Major Climatic and Ecosystem Change." Marine Ecology Progress Series 198:215-224.

Bering Sea Impact Study Project Office. 1997. The Impacts of Global Climate Change in the Bering Sea Region-Results of a Workshop, Girdwood, Alaska. University of Alaska BESIS Project Office, Fairbanks. 
Bering Ecosystem Study Planning Group. 2004. BEST: Bering Ecosystem Study Science Plan Planning Workshop, 17-19 March 2003, Seattle, Washington. Bering Ecosystem Study (BEST) Planning Group, University of Washington, Seattle.

BESIS. See Bering Sea Impact Study.

BEST. See Bering Ecosystem Study.

Bond, N.A., and J.E. Overland. 2005. "The Importance of Episodic Weather Events to the Ecosystem of the Bering Sea Shelf." Fisheries Oceanography 14(2):97-111.

Brodeur, R.D., C.E. Mills, J.E. Overland, G.E. Walters, and J.D Schumacher. 1999. "Evidence for a Substantial Increase in Gelatinous Zooplankton in the Bering Sea, with Possible Links to Climate Change." Fisheries Oceanography 8(4):296-306.

Broerse, A.T.C., T. Tyrrell, J.R.Young, A.J. Poulton, A. Merico, W.M. Balch, and P.I. Miller. 2003. "The Cause of Bright Waters in the Bering Sea in Winter." Continental Shelf Research 23(16):1579-1596.

Budge, S.M., S.J. Iverson, A.M. Springer, and C.P. McRoy. 2002. "Elucidating Trophic Pathways of Sea Ice Algae Using Fatty Acid Signatures." Connectivity in Northern Waters: Arctic Ocean, Bering Sea, and Gulf of Alaska Interrelationships-53rd Arctic Science Conference. Arctic Division, American Association for the Advancement of Science, Anchorage.

Chen, M., Y.P. Huang, P.G. Cai, and L.D. Guo. 2003. "Particulate Organic Carbon Export Fluxes in the Canada Basin and Bering Sea as Derived from Th-234/U-238 Disequilibria." Arctic 56(1):32-44.

Cherniawsky, J.Y., W.R. Crawford, O.P. Nankitin, and E.C. Carmack. 2005. "Bering Strait Transports from Satellite Altimetry." Journal of Marine Research 63:887-900.

Chernyak, S.M., C.P. Rice, and L.L. McConnell. 1996. "Evidence of Currently-Used Pesticides in Air, Ice, Fog, Seawater and Surface Microlayer in the Bering and Chukchi Seas." Marine Pollution Bulletin 32(5):410-419.

CIFAR. See Cooperative Institute for Arctic Research.

Cokelet, E.D., and P.J. Stabeno. 1997. "Mooring Observations of the Thermal Structure, Density Stratification and Currents in the Southeastern Bering Sea Basin." Journal of Geophysical Research 102(C10):22947-22964.

Cokelet, E.D., M.L. Schall, and D. Dougherty. 1996. “ADCP-Referenced Geostrophic Circulation in the Bering Sea Basin." Journal of Physical Oceanography 26:1113-1128. 
Connors, M.E., A.B. Hallowed, and E. Brown. 2002. "Retrospective Analysis of Bering Sea Bottom Trawl Surveys: Regime Shift and Ecosystem Reorganization.” Progress in Oceanography 55:209-222.

Cooper, L. W J.M. Grebmeier, I.L. Larsen, V.G. Egorov, C. Theodorakis, H.P. Kelly, and J.R. Lovvorn. 2002. "Seasonal Variation in Sedimentation of Organic Materials in the St. Lawrence Island Polynya Region.” Bering Sea Marine Ecology Progress Series 226:13-26.

Cooperative Institute for Arctic Research. 2003. Annual Report, 1 July 2002 - 30 June 2003, Year 2 of Cooperative Agreement No. NA17RJ1224. Cooperative Institute for Arctic Research, University of Alaska, Fairbanks.

Cooperative Institute for Arctic Research. 2004. Annual Report, 1 July 2003 - 30 June 2004, Year 3 of Cooperative Agreement NA17RJ1224. Cooperative Institute for Arctic Research, University of Alaska, Fairbanks.

Cooperative Institute for Arctic Research. 2005. Annual Report, 1 July 2004 - 30 June 2005, Year 4 of Cooperative Agreement NA17RJ1224. Cooperative Institute for Arctic Research, University of Alaska, Fairbanks.

Coyle, C.O. 2005. "Zooplankton Distribution, Abundance and Biomass Relative to Water Masses in Eastern and Central Aleutian Island Passes." Fisheries Oceanography 14 (Suppl. 1):77-92.

Doyle, M.J., K.L. Mier, M.S. Busby, and R.D. Brodeur. 2002. "Regional Variation in Springtime Ichthyoplankton Assemblages in the Northeast Pacific Ocean." Progress in Oceanography 53(2-4):247-281.

Duffy-Anderson, J.T., M.S. Busby, K.L. Mier, C.M. Deliyanides, and P.J. Stabeno. 2006. "Spatial and Temporal Patterns in Summer Ichthyoplankton Assemblages on the Eastern Bering Sea Shelf 1996-2000.” Fisheries Oceanography 15:80-94.

Gradinger, R.R., and B.A. Bluhm. 2005. Susceptibility of Sea Ice Biota to Disturbances in the Shallow Beaufort Sea. Phase 1: Biological Coupling of Sea Ice with the Pelagic and Benthic Realms. OCS Study MMS 2005-062. U.S. Department of Interior, Minerals Management Service, Alaska Outer Continental Shelf Region, Anchorage.

Grebmeier, J.M. 1999. "Bering Strait: A Vital Ocean and Ecosystem Connection, Benthic Productivity and Carbon Cycling." In NOAA's Arctic Research Initiative: The First Three Years. U.S. Department of Commerce, National Oceanic and Atmospheric Administration, Arctic Research Office, Silver Spring, Maryland.

Grebmeier, J. 2006. Western Arctic Shelf-Basin Interactions (SBI) Project. University of Tennessee, Knoxville. Available at: http://sbi.utk.edu/ (accessed August 7, 2007). 
Grebmeier, J.M., and K.J. Dunton. 2000. "Benthic Processes in the Northern Bering/Chukchi Seas: Status and Global Change." In H.P. Huntington (ed.), Impacts of Changes in Sea Ice and Other Environmental Parameters in the Arctic. Marine Mammal Commission, Bethesda, Maryland.

Grebmeier, J.M., J.E. Overland, S.E. Moore, E.V. Farley, E.C. Carmack, L.W. Cooper, K.E. Frey, J.H. Halle, F.A. McLaughlin, and S.L. McNutt. 2006. "A Major Ecosystem Shift in the Northern Bering Sea." Science 311:1461-1464.

Hare, S.R., and N.J. Mantua. 2002. "Empirical Evidence for North Pacific Regime Shifts in 1977 and 1989." Progress in Oceanography 53:103-145.

Herman, A.J., P.J. Stabeno, D.B. Haidvogel, and D.L. Musgrave. 2002. “A Regional Tidal/Subtidal Circulation Model of the Southeastern Bering Sea: Development, Sensitivity Analysis and Hindcasting." Deep-Sea Research Part II 49:5495-5967.

Hoff, G.R. 2006. "Biodiversity as an Index of Regime Shift in the Eastern Bering Sea." Fishery Bulletin 104(3):445-455.

Hunt, G.L., Jr., P. Stabeno, G. Walters, E. Sinclair, R.D. Brodeur, J.M. Napp, and N.A. Bond. 2002. "Climate Change and Control of the Southeastern Bering Sea Pelagic Ecosystem.” Deep-Sea Research II 49:5821-5853.

Hunt, G.L., Jr., and P.J. Stabeno. 2002. "Climate Change and the Control of Energy Flow in the Southeastern Bering Sea." Progress in Oceanography 53:5-22.

Hunt, G.L., Jr., and P.J. Stabeno. 2005. "Oceanography and Ecology of the Aleutian Archipelago: Spatial and Temporal Variation." Fisheries Oceanography 14 (Suppl. 1):292-306.

Huntington, H.P. 2000. Impacts of Changes in Sea Ice and Other Environmental Parameters in the Arctic. Final Report of the Marine Mammal Commission Workshop, Girdwood, Alaska. Marine Mammal Commission. Bethesda, Maryland.

Interagency Arctic Research Policy Committee. 2005. Arctic Research of the United States. National Science Foundation, Office of Polar Programs, Arlington, Virginia. Available at: http://www.nsf.gov/od/opp/arctic/arctrsch/start.jsp (accessed August 6, 2007).

Jin, M., C.J. Deal, J. Wang, N. Tanaka, and M. Ikeda. 2006. "Vertical Mixing Effects on the Phytoplankton Bloom in the Southeastern Bering Sea Midshelf." Journal of Geophysical Research 111(C03002).

Johnson, G.C., P.J. Stabeno, and S.C. Riser. 2004. "The Bering Slope Current System Revisited." Journal of Physical Oceanography 34:384-398. 
Kachel, N.B., G.L. Hunt, S.A. Salo, J.D. Schumacher, P.J. Stabeno, and T.E. Whitledge. 2002. "Characteristics and Variability of the Inner Front of the Southeastern Bering Sea." Deep Sea Research Part II: Topical Studies in Oceanography 49(26):5889-5909.

Kaltin, S., and L.G. Anderson. 2005. "Uptake of Atmospheric Carbon Dioxide in Arctic Shelf Seas: Evaluation of the Relative Importance of Processes that Influence $\mathrm{pCO}_{2}$ in Water Transported over the Bering-Chukchi Sea Shelf." Marine Chemistry 94:67-79.

Khen, G.V. 2005. Oceanographic Condition of the Bering Sea in BASIS. NPAFC Technical Report No. 6, North Pacific Anadromous Fish Commission, Vancouver, British Columbia.

King, J.R. 2005. Report of the Study Group on Fisheries and Ecosystem Responses to Recent Regime Shifts. North Pacific Marine Science Organization, Sidney, British Columbia.

Kowalik, Z. 1999. "Bering Sea Tides.” pp. 93-177 in T.R. Loughlin and K. Ohtani (eds.), Dynamics of the Bering Sea. University of Alaska Sea Grant, AK-SG-99-03, Fairbanks.

Krembs, C., H. Eicken, K. Junge, and J.W. Denning. 2002. "High Concentrations of Exopolymeric Substances in Arctic Winter Sea Ice: Implications for the Polar Ocean Carbon Cycle and Cryoprotection of Diatoms.” Deep-Sea Research Part I 49:2163-2181.

Ladd, C., J. Hahncke, G.L. Hunt, Jr., K.O. Coyle, and P.J. Stabeno. 2005a. "Hydrographic Features and Seabird Foraging in Aleutian Passes." Fisheries Oceanography 14 (Suppl. 1):178195.

Ladd, C., G.L. Hunt, Jr., C.W. Mordy, S.A. Salo, and P.J. Stabeno. 2005b. "Marine Environment of the Eastern and Central Aleutian Islands." Fisheries Oceanography 14 (Suppl. 1):22-38.

Livingston, P., R. McCoy, and P. Rigby. 1997. Bering Sea Ecosystem Workshop Report, Anchorage, Alaska, December 4-5, 1997. U.S. Department of Commerce, National Oceanic and Atmospheric Administration, National Marine Fisheries Service, Seattle, Washington.

Loughlin, T.R., and K. Ohtani. 1999. Dynamics of the Bering Sea. University of Alaska Sea Grant, AK-SG-99-03, Fairbanks.

Lovvren, J.R., L.W. Cooper, M.L. Brooks, C.C. De Ruyck, J.K. Bump, and J.M. Grebmeier. 2005. "Organic Matter Pathways to Zooplankton and Benthos under Pack Ice in Late Winter and Open Water in Late Summer in the North-Central Bering Sea." Marine Ecology Progress Series 291:135-150.

Luchin, V.A., V.A. Menovshchikov, V.M. Lavrentiev, and R.K. Reed. 1999. "Thermohaline Structure and Water Masses in the Bering Sea." pp. 61-92 in T.R. Loughlin and K. Ohtani (eds.), Dynamics of the Bering Sea. University of Alaska Sea Grant, AK-SG-99-03, Fairbanks.

Luchin, V.A., I.P. Semiletov, and G.E. Weller. 2002. "Atmosphere-Ice-Water System in the Second Half of the Twentieth Century." Progress in Oceanography 55:23-44. 
MacDonald, R.W., D. Mackay, Y.F. Li, and B. Hickie. 2003. "How Will Global Climate Change Affect Risks from Long-Range Transport of Persistent Organic Pollutants?" Human and Ecological Risk Assessment 9(3):643-660.

Macklin, S.A. 1999. Report on the Fisheries-Oceanography Coordinated Investigations International Workshop on Recent Conditions in the Bering Sea, Seattle, Washington, November 9-10, 1998. PMEL Contribution 2044, NOAA ERL Special Report, Pacific Marine Environmental Laboratory, Seattle, Washington.

Merico, A., T. Tyrrell, C.W. Brown, S.B. Groom, and P.I. Miller. 2003. "Analysis of Satellite Imagery for Emiliania huxleyi Blooms in the Bering Sea before 1997." Geophysical Research Letters 30(6):1337.

Minobe, S. 2002. "Interannual to Interdecadal Changes in the Bering Sea and Concurrent 1998/99 Changes over the North Pacific.” Progress in Oceanography 55:45-64.

Mizobata, K., and S. Saitoh. 2003. "Characteristics of Cyclonic and Anticyclonic Eddies in the Southeastern Bering Sea 1998-2000 Using TOPEX/Poseidon Proceedings of the SPIE.” International Journal for Optical Engineering 4895:473-481.

Mizobata, K., and S. Saitoh. 2004. "Variability of Bering Sea Eddies and Primary Productivity along the Shelf Edge during 1998-2000 Using Satellite Multisensor Remote Sensing." Journal of Marine Systems 50:101-111.

Mordy, C.W., P.J. Stabeno, C. Ladd, S. Zeeman, D.P. Wisegarver, S.A. Salo, and G.L. Hunt, Jr. 2005. "Nutrients and Primary Production along the Eastern Aleutian Island Archipelago." Fisheries Oceanography 14 (Suppl. 1):55-76.

Napp, J.M., and G.L. Hunt, Jr. 2001. "Anomalous Conditions in the Southeastern Bering Sea 1997: Linkages among Climate, Weather, Ocean and Biology." Fisheries Oceanography 10:61-68.

Napp, J.M., A.W. Kendall, and J.D. Schumacher. 2000. "A Synthesis of Biological and Physical Processes Affecting the Feeding Environment of Larval Walleye Pollock (Theragra chalcogramma) in the Eastern Bering Sea." Fisheries Oceanography 9(2):147-162.

National Oceanic and Atmospheric Administration. 2006. Arctic Theme Page. U.S. Department of Commerce, National Oceanic and Atmospheric Administration. Available at: http://www.arctic.noaa.gov/ (accessed July 31, 2007).

Niebauer, H.J. 1998. "Variability in Bering Sea Ice Cover as Affected by a Regime Shift in the North Pacific in the Period 1947-1999." Journal of Geophysical Research 103(C12):2771727737. 
Niebauer, H.J., V. Alexander, and S. Henrichs. 1996. "Time Series of the Spring Bloom from the Bering Sea Ice Edge in Spring." Continental Shelf Research 15:1859-1877.

Niebauer, A.J., N.A. Bond, L.P. Yakunin, and V.V. Plotnikov. 1999. “An Update on the Climatology and Sea Ice of the Bering Sea.” pp. 29-39 in T.R. Loughlin and K. Ohtani (eds.), Dynamics of the Bering Sea. University of Alaska Sea Grant, AK-SG-99-03, Fairbanks.

NOAA. See National Oceanic and Atmospheric Administration.

North Pacific Research Board. 2005. North Pacific Research Board Science Plan. First Edition. North Pacific Research Board, Anchorage.

NPRB. See North Pacific Research Board.

Okkonen, S.R. 2001 "Altimeter Observations of the Bering Slope Current Eddy.” Journal of Geophysical Research 106:2465-2476.

Okkonen, S.R., G.M. Schmidt, E.D. Cokelet, and P.J. Stabeno. 2004. "Satellite and Hydrographic Observations of the Bering Sea 'Green Belt." Deep Sea Research Part II: Topical Studies in Oceanography 51(10-11):1033-1051.

Overland, J.E., and P.J. Stabeno. 2004. "Is the Climate of the Bering Sea Warming and Affecting the Ecosystem?" EOS, Transactions of the American Geophysical Union 85(13):309-312.

Overland, J.E., F. Fetterer, D. McGuire. J. Richter-Menge, and J. Walsh. 2002. SEARCH Workshop on Large-Scale Atmosphere/Cryosphere Observations. Contribution 2452 from National Oceanic and Atmospheric Administration, Pacific Marine Environmental Laboratory, Seattle, Washington.

Radi, T., D.E. Vernal, and O. Peyron. 2001. "Relationships between Dinoflagellate Cyst Assemblages in Surface Sediment and Hydrographic Conditions in the Bering and Chukchi Seas.” Journal of Quaternary Science 16(7):667-680.

Reed, R.K. 1998. "Confirmation of a Convoluted Flow over the Southeastern Bering Sea Shelf." Continental Shelf Research 18:99-103.

Reed, R.K., and P.J. Stabeno 1996. "On the Climatological Net Circulation over the Eastern Bering Sea Shelf.” Continental Shelf Research 16(10):1297-1305.

Reed, R.K., and P.J. Stabeno. 1997. "Long-Term Measurements of Flow near the Aleutian Islands." Journal of Marine Research 55:565-575.

Reed, R.K., and P.J. Stabeno. 1999. "The Aleutian North Slope Current.” pp. 177-192 in T.R. Loughlin and K. Ohtani (eds.), Dynamics of the Bering Sea. University of Alaska Sea Grant, AK-SG-99-03, Fairbanks. 
Robertson, D.G. 1997. "Bering and Chukchi Sea Bathymetry Coverages.” U.S. Geological Survey, Biological Resources Division, Alaska Science Center-Biological Science Office, Anchorage.

Rodionov, S.N., J.E. Overland, and N.A. Bond. 2005a. "The Aleutian Low and Winter Climatic Conditions in the Bering Sea. Part I: Classification." Journal of Climate 18:160-177.

Rodionov, S.N., J.E. Overland, and N.A. Bond. 2005b. "Spatial and Temporal Variability of the Aleutian Climate." Fisheries Oceanography 14 (Suppl. 1):3-21.

Rodionov, S.N., P. Stabeno, J. Overland, N. Bond, and S. Salo. 2005c. Eastern Bering Sea2005. Science Reports on the Bering Sea Climate Status and Trends, NOAA. Available at: http://www.beringclimate.noaa.gov/reports/ (accessed on August 6, 2007).

Sasaki, Y.N., and S. Minobe. 2005. "Seasonally Dependent Interannual Variability of Sea Ice in the Bering Sea and Its Relation to Atmospheric Fluctuations." Journal of Geophysical Research 110:C05011.

Schell, D.M. 1998. "Isotope Ratio Evidence of Declining Primary Productivity in the Bering Sea.” MMS Series 98-031, U.S. Department of Interior, Minerals Management Service, Fairbanks.

Schell, D.M. 2000. "Declining Carrying Capacity in the Bering Sea: Isotopic Evidence from Whale Baleen." Limnology and Oceanography 45:459-462.

Schumacher, J.D., and P.J. Stabeno. 1998. "The Continental Shelf of the Bering Sea." In A.R. Robinson and K.H. Brink (eds.), The Sea: The Global Coastal Ocean Regional Studies and Synthesis, Vol. XI:869-909. John Wiley and Sons, New York.

Schumacher, J.D., N.A. Bond, R.D. Brodeur, P.A. Livingston, J.M. Napp, and P.J. Stabeno. 2003. "Climate Change in the Southeastern Bering Sea and Some Consequences for Biota." In Hempel and Sherman (eds.), Large Marine Ecosystems of the World-Trends in Exploitation, Protection, and Research. Elsevier, Amsterdam.

Smith, O.P., and W.J. Lee. 2005. "Alaska Sea Ice Atlas.” In University of Alaska, Coastal Marine Institute Annual Report No. 11. OCS Study MMS 2005-055, University of Alaska, Fairbanks, and Minerals Management Service, Alaska Outer Continental Shelf Region, Anchorage.

Springer, A.M., C.P. McRoy, and M.V. Flint. 1996. "The Bering Sea Green Belt: Shelf Edge Processes and Ecosystem Production." Fisheries Oceanography 5:205-223.

Stabeno, P.J., and J.E. Overland. 2001. "Bering Sea Shifts toward an Earlier Spring Transition." EOS, Transactions of the American Geophysical Union 82:317-321. 
Stabeno, P.J., J.D. Schumacher, R.F. Davis, and J.M. Napp. 1998. "Under-Ice Observations of Water Column Temperature, Salinity and Spring Phytoplankton Dynamics: Eastern Bering Sea Shelf." Journal of Marine Research 56:239-255.

Stabeno, P.J., J.D. Schumacher, and K. Ohtani. 1999. "The Physical Oceanography of the Bering Sea." pp. 1-160 in T.R. Loughlin and K. Ohtani (eds.), Dynamics of the Bering Sea. University of Alaska Sea Grant, AK-SG-99-03, Fairbanks.

Stabeno P.J., N.A. Bond, N.B. Kachel, S.A. Salo, and J.D. Schumacher. 2001. “On The Temporal Variability of the Physical Environment over the South-Eastern Bering Sea." Fisheries Oceanography 10:81-98.

Stabeno, P.J., N.B. Kachel, M. Sullivan, and T.E. Whitledge. 2002a. "Variability of Physical and Chemical Characteristics along the 70-M Isobath of the Southeastern Bering Sea." Deep Sea Research Part II 49(26):5931-5943.

Stabeno, P.J., R.K. Reed, and J.M. Napp. 2002b. "Transport through Unimak Pass.” Alaska Deep Sea Research Part II: Topical Studies in Oceanography 49(26):5919-5930.

Stabeno, P.J., G.L. Hunt, Jr., and S.A. Macklin. 2005a. "Introduction to Processes Controlling Variability in Productivity and Ecosystem Structure of the Aleutian Archipelago." Fisheries Oceanography 14 (Suppl. 1):1-2.

Stabeno, P.J., D.G. Kachel, N.B. Kachel, and M.E. Sullivan. 2005b. “Observations from Moorings in the Aleutian Passes: Temperature, Salinity and Transport." Fisheries Oceanography 14 (Suppl. 1):39-54.

Stabeno, P., J. Napp, and T. Whitledge. 2006. A Decade of Change on the Southeastern Bering Sea Shelf. NPRB Project 2003 Final Report, North Pacific Research Board, Anchorage.

Steward, G.F., D.C. Smith, and F. Azam. 1996. "Abundance and Production of Bacteria and Viruses in the Bering and Chukchi Seas.” Marine Ecology-Progress Series 131(1-3):287-300.

Strachan, W.M.J., D.A. Burniston, W. Williamson, and H. Bohdanowicz. 2001. "Spatial Differences in Persistent Organochlorine Pollutant Concentrations between the Bering and Chukchi Seas." Marine Pollution Bulletin 43(1-6):132-142.

Tynan, C.T. 1999. "Redistributions of Cetaceans in the Southeastern Bering Sea Relative to Anomalous Oceanographic Conditions during the 1997 El Niño.” pp. 115-77 in H.J. Freeland, W.T. Peterson, and A. Tyler (eds.), Proceedings of the 1998 Science Board Symposium on the Impacts of the 1997/98 El Niño Event on the North Pacific Ocean and its Marginal Seas. North Pacific Marine Science Organization (PICES), Sidney, British Columbia.

University of Alaska Anchorage. 2001. Alaska Sea Ice Atlas Publications. University of Alaska Anchorage, School of Engineering. Available at:

http://holmes-iv.engr.uaa.alaska.edu/publications.html (accessed August 6, 2007). 
USGS. See U.S. Geological Survey.

U.S. Geological Survey. 2007. "Bering and Chukchi Sea Databases-Bathymetry Coverages." U.S. Geological Survey, Alaska Science Center, Anchorage. Available at: http://alaska.usgs.gov/science/biology/walrus/bering/bathy/index.html (accessed August 6, 2007).

van Meurs, P., and P.J. Stabeno. 1999. "Evidence of Episodic On-Shelf Flow in the Southeastern Bering Sea." Journal of Geophysical Research 104:29715-29720.

Vance, T., J. Schumacher, P. Stabeno, C. Baier, T. Wyllie-Echeverria, C. Tynan, R. Brodeur, and J. Napp. 1998. "Aquamarine Waters Recorded for First Time in Eastern Bering Sea." EOS, Transactions of the American Geophysical Union 79(10):121.

Vlietstra, L.S., K.O. Coyle, N.B. Kachel, and G.L. Hunt, Jr. 2005. "Tidal Front Affects the Size of Prey Used by a Top Marine Predator, the Short-Tailed Shearwater (Puffinus tenuirostris)." Fisheries Oceanography 14 (Suppl. 1):196-211.

Wang, B. 1999. Spatial Distribution of Chemical Constituents in the Kuskokwim River, Alaska. USGS Water-Resources Investigations Report 99-4177. U.S. Geological Survey, Anchorage.

Weller, G., P. Anderson, and G. Nelson. 1998. "Alaska and the Bering Sea Regional Workshop on Climate Change Impacts." Alaska and the Bering Sea Regional Workshop on Climate Change Impacts. Aspen Global Change Institute, Aspen, Colorado.

Wells, M., J.J. Walsh, D.A. Dieterle, F.E. Müller-Karger, K. Aagaard, A.T. Roach, T.E. Whitledge, and D. Stockwell. 1997. " $\mathrm{CO}_{2}$ Cycling in the Coastal Ocean. II. Seasonal Organic Loading of the Arctic Ocean from Source Waters in the Bering Sea." Continental Shelf Research 17(1):1-36.

Williams, E.H. 1999. Interrelationships of Pacific Herring, Clupea pallasi Populations and Their Relation to Large-Scale Environmental and Oceanographic Variables. Thesis, University of Alaska, Fairbanks.

Wirts, A.E., and G.C. Johnson. 2005. "Recent Interannual Upper Ocean Variability in the Deep Southeastern Bering Sea." Journal of Marine Research 63:381-404.

Woodgate, R.A., and K. Aagaard. 2004. "Revising the Bering Strait Freshwater Flux into the Arctic Ocean." Geophysical Research Letters 32:L02062.

Woodgate, R.A., K. Aagaard, and T.J. Weingartner. 2005. "Monthly Temperature, Salinity, and Transport Variability of the Bering Strait through flow." Geophysical Research Letters 32:L04601. 
Wyllie-Escheverria, T., and W.S. Wooster. 1998. "Year-to-Year Variations in Bering Sea Ice Cover and Some Consequences for Fish Distributions." Fisheries Oceanography 7(2):159-170.

Wyllie-Escheverria, T., and K. Ohtani. 1999. "The Role of Ice in Organizing the Bering Sea Ecosystem." pp. 435-451 in T.R. Loughlin and K. Ohtani (eds.), Dynamics of the Bering Sea. University of Alaska Sea Grant, AK-SG-99-03, Fairbanks.

Yao, Z.W., G.B. Jiang, and H.Z. Xu. 2002. "Distribution of Organochlorine Pesticides in Seawater of the Bering and Chukchi Sea." Environmental Pollution 116(1):49-56.

\subsection{FISH AND FISHERIES}

ADFG. See Alaska Department of Fish and Game.

Adkinson, M.D., and B.P. Finney. 2003. "The Long-Term Outlook for Salmon Returns in Alaska." Alaska Fishery Research Bulletin 10(2):83-94.

ADNR. See Alaska Department of Natural Resources.

Alaska Department of Fish and Game. 1997. Bristol Bay Area Commercial Fisheries Annual Management Report, 1996. Regional Information Report, No. 2A97-14, Alaska Department of Fish and Game, Division of Commercial Fisheries Management and Development, Anchorage.

Alaska Department of Fish and Game. 1997. Western Region Shellfish Fisheries Annual Management Report. Regional Information Report, No. 4K97-15, Alaska Department of Fish and Game, Division of Commercial Fisheries, Management and Development, Kodiak.

Alaska Department of Fish and Game. 2004. "ADF\&G Announces Fishery Closures Surrounding the Selendang Ayu Oil Spill." Alaska Department of Fish and Game, Division of Commercial Fisheries, Juneau. Available at:

http://www.cf.adfg.state.ak.us/region4/news/2004/nr122704.pdf (accessed August 7, 2007).

Alaska Department of Fish and Game. 2005. "ADF\&G Announces Reopening of Commercial Fishing in Skan and Makushin Bays." Alaska Department of Fish and Game, Division of Commercial Fisheries, Juneau. Available at:

http://www.cf.adfg.state.ak.us/region4/news/2005/nr100605.pdf (accessed August 7, 2007).

Alaska Department of Fish and Game. 2006a. Bristol Bay Salmon Fisheries by District. Alaska Department of Fish and Game, Division of Commercial Fisheries, Juneau. Available at: http://www.cf.adfg.state.ak.us/region2/finfish/salmon/maps/bb_all.php (accessed August 6, 2007). 
Alaska Department of Fish and Game. 2006b. "Bristol Bay Salmon Fisheries Historical Information." Alaska Department of Fish and Game, Division of Commercial Fisheries, Juneau. Available at: http://www.cf.adfg.state.ak.us/region2/finfish/salmon/bbay/bbayhist.php (accessed February 23, 2007).

Alaska Department of Fish and Game. 2006c. Shellfish Fisheries Kodiak, Alaska Peninsula, Bering Sea, and Aleutian Islands. Alaska Department of Fish and Game, Division of Commercial Fisheries, Juneau. Available at:

http://www.cf.adfg.state.ak.us/region4/shellfsh/shelhom4.php (accessed August 6, 2007).

Alaska Department of Fish and Game. 2006d. Togiak (Bristol Bay) Herring Fishery Historical Information. Alaska Department of Fish and Game, Division of Commercial Fisheries, Juneau. Available at:

http://www.cf.adfg.state.ak.us/region2/finfish/herring/togiak/toghhist.php (accessed August 6, 2007).

Alaska Department of Fish and Game. 2006e. "Fish Distribution Database (FDD)." Available at: http://www.sf.adfg.state.ak.us/SARR/FishDistrib/anadcat.cfm (accessed on August 6, 2007).

Alaska Department of Fish and Game. 2006f. "Subsistence Fisheries Annual Reports, 19992003." Available at: http://www.subsistence.adfg.state.ak.us/geninfo/publctns/articles.cfm (accessed on August 6, 2007).

Alaska Department of Natural Resources. 2005a. "Chapter 3: Habitat, Fish and Wildlife." In Alaska Peninsula Areawide Oil and Gas Lease Sale, Final Finding of the Director July 25, 2005. Alaska Department of Natural Resources, Division of Oil and Gas, Anchorage.

Alaska Department of Natural Resources. 2005b. "Appendix E. Catalogued Anadromous Fish Streams of the Alaska Peninsula." In Alaska Peninsula Areawide Oil and Gas Lease Sale, Final Finding of the Director July 25, 2005. Alaska Department of Natural Resources, Division of Oil and Gas, Anchorage.

Alaska Regional Response Team. 2001. "Sensitive Areas.” In Bristol Bay Subarea Contingency Plan for Oil and Hazardous Substance Discharge Releases. Alaska Regional Response Team, Alaska Department of Environmental Conservation, U.S. Coast Guard, and U.S. Environmental Protection Agency, Anchorage.

Arctic Yukon Kuskokwim Sustainable Salmon Initiative. 2006. Arctic-Yukon-Kuskokwim Salmon Research and Restoration Plan. Bering Sea Fishermen's Association, Anchorage.

ARRT. See Alaska Regional Response Team.

Aydin, K.Y. 2002. "The Eastern Bering Sea." pp. 33-38 in T. Pitcher and K. Cochrane (eds.), The Use of Ecosystem Models to Investigate Multispecies Management Strategies for Capture Fisheries. Fisheries Centre Research Reports, University of British Columbia, Vancouver. 
AYK-SSI. See Arctic Yukon Kuskokwim Sustainable Salmon Initiative.

Bailey, K.M. 2000. "Shifting Control of Recruitment of Walleye Pollock Theragra chalcogramma after a Major Climatic and Ecosystem Change." Marine Ecology Progress Series 198:215-224.

Bailey, K.M., P.J. Stabeno, and D.A. Powers. 1997. "The Role of Larval Retention and Transport Features in Mortality and Potential Gene Flow of Walleye Pollock." Journal of Fish Biology 51:135-154.

Bailey, K.M., T.J. Quinn, P. Bentzen, and W.S. Grant. 2000. "Population Structure and Dynamics of Walleye Pollock, Theragra chalcogramma." Advances in Marine Biology $37: 179-255$.

Baker, T.T., L.F. Fair, R.A. Clark, and J.J. Hasbrouk. 2006. Review of Salmon Escapement Goals in Bristol Bay, Alaska, 2006. Fishery Manuscript No. 06-05. Alaska Department of Fish and Game, Division of Sport Fish and Commercial Fisheries, Anchorage.

Barnard, D.R., and R. Burt. 2006. Summary of the 2005 Mandatory Shellfish Observer Program Database for the Non-rationalized Bering Sea Crab Fisheries. Fishery Data Series No. 06-36. Alaska Department of Fish and Game, Division of Sport Fish and Commercial Fisheries, Anchorage.

Barnard, D.R., and D. Pengilley. 2006. Estimates of Red King Crab Bycatch during the 2005/2006 Bristol Bay Red King Crab Fishery with Comparisons to the 1999-2004 Seasons. Fishery Data Series No. 06-03. Alaska Department of Fish and Game, Division of Sport Fish and Commercial Fisheries, Anchorage.

Barnhart, J.P. 2006. Annual Management Report for the Commercial Weathervane Scallop Fisheries in Alaska's Westward Region, 2004/05. Fishery Management Report No. 06-41. Alaska Department of Fish and Game, Division of Sport Fish and Commercial Fisheries, Anchorage.

Barnhart, J.P., and G.E. Rosenkranz. 2006. Summary and Analysis of Onboard ObserverCollected Data from the 2002/2003 Statewide Commercial Weathervane Scallop Fishery. Fishery Management Report No. 06-39. Alaska Department of Fish and Game, Division of Sport Fish and Commercial Fisheries, Anchorage.

Blaylock, R.B., L. Margolis, and J.C. Holmes. 2003. "The Use of Parasites in Discriminating Stocks of Pacific Halibut (Hippoglossus stenolepis) in the Northeast Pacific." Fishery Bulletin 101(1):1-9.

Blood, D.M. 2002. "Low-Temperature Incubation of Walleye Pollock (Theragra chalcogramma) Eggs from the Southeastern Bering Sea Shelf and Shelikof Strait, Gulf of Alaska." Deep-Sea Research II-Topical Studies in Oceanography 49(26):6095-6108. 
Bond, N.A., and J.E. Overland. 2005. "The Importance of Episodic Weather Events to the Ecosystem of the Bering Sea Shelf." Fisheries Oceanography 14(2):97-111.

Bowers, F.R., K.L. Cush, M. Schenzfeier, J. Barnhart, M. Bon, M.E. Calvin, Jr., S. Coleman, B. Failor-Rounds, K. Milani, and M. Salmon. 2005. Annual Management Report for the Commercial and Subsistence Shellfish Fisheries of the Aleutian Islands, Bering Sea and the Westward Region's Shellfish Observer Program, 2004. Fishery Management Report No. 0551. Alaska Department of Fish and Game, Division of Sport Fish and Commercial Fisheries, Anchorage.

Brodeur, R.D., K.W. Myers, and J.H. Helle. 2003. "Research Conducted By The United States on the Early Ocean Life History of Pacific Salmon." North Pacific Anadromous Fish Commission Bulletin 3:89-131.

Buklis, L.S. 1999. "A Description of Economic Changes in Commercial Salmon Fisheries in a Region of Mixed Subsistence and Market Economies." Arctic 52(1):40-48.

Byerly, M., B. Brooks, B. Simonson, H. Savikko, and H.J. Geiger. 1999. Alaska Commercial Salmon Catches, 1878-1997. Regional Information Report No. 5J99-05. Alaska Department of Fish and Game, Division of Commercial Fisheries, Juneau.

Callaway, D.G. 1997. Subsistence Fisheries-Implications of Global Change in Alaska and the Bering Sea Regions: Proceedings of a Workshop. University of Alaska, Fairbanks.

Cascorbi, A. 2004. King Crab: Paralithodes camtschaticus (Red King Crab), Paralithodes platypus (Blue King Crab), Lithodes aequispinus (Golden King Crab), Lithodes couesi (Scarlet King Crab). Seafood Watch Seafood Report. Monterey Bay Aquarium, Monterey, California.

CFEC. See Commercial Fisheries Entry Commission.

Christian, J.R., A. Mathieu, D.H. Thomson, D. White, and R.A. Buchanan. 2003. Effect of Seismic Energy on Snow Crab (Chionoecetes opilio). Environmental Research Funds Report No. 144. LGL Environmental Research Associates Ltd. and Oceans Ltd, Calgary, Alberta.

Clark, J.H. 2005a. Abundance of Sockeye Salmon in the Alagnak River System of Bristol Bay Alaska. Fishery Manuscript No. 05-01. Alaska Department of Fish and Game, Division of Sport Fish and Commercial Fisheries, Anchorage.

Clark, J.H. 2005b. Bristol Bay Salmon, A Program Review. Special Report No. 05-02. Alaska Department of Fish and Game, Division of Sport Fish and Commercial Fisheries, Anchorage.

Commercial Fisheries Entry Commission. 2004. Commercial Fisheries Entry Commission Report 2004. Juneau, Alaska. 
Commercial Fisheries Entry Commission. 2005. Commercial Fisheries Entry Commission Report 2005. Juneau, Alaska.

Connors, M.E., A.B. Hallowed, and E. Brown. 2002. "Retrospective Analysis of Bering Sea Bottom Trawl Surveys: Regime Shift and Ecosystem Reorganization." Progress in Oceanography 55:209-222.

DeCicco, F. 2003. Fishery Management Report for Sport Fisheries in the Northwest Alaska Management Area, 2001. Fishery Management Report No. 03-06. Alaska Department of Fish and Game, Division of Sport Fish, Research, and Technical Services, Anchorage.

Department of Commerce. 1997. "Fisheries of the Exclusive Economic Zone off Alaska; Management Measures to Reduce Seabird Bycatch in the Hook-and-Line Groundfish Fisheries." U.S. Department of Commerce, National Oceanic and Atmospheric Administration, National Marine Fisheries Service. Federal Register 62:23176-23184.

Department of Commerce. 1998. "Halibut Fisheries in U.S. Convention Waters off Alaska; Fisheries of the Exclusive Economic Zone off Alaska; Management Measures to Reduce Seabird Bycatch in the Hook-and-Line Halibut and Groundfish Fisheries." U.S. Department of Commerce, National Oceanic and Atmospheric Administration, National Marine Fisheries Service. Federal Register 63(44):11161-11167.

Dieter, B.E., D.A. Wion, and R.A. McConnaughey. 2003. Mobile Fishing Gear Effects on Benthic Habitats: A Bibliography. Second Edition. NOAA Technical Memorandum NMFSAFSC-135. National Oceanographic and Atmospheric Administration, Alaska Fisheries Science Center, Anchorage.

DOC. See Department of Commerce.

Downton, M.W., and K.A. Miller. 1998. "Relationships between Alaskan Salmon Catch and North Pacific Climate on Interannual and Interdecadal Time Scales." Canadian Journal of Fisheries and Aquatic Sciences 55:2255-2265.

DuBois, L. 2002. Pacific Herring Stocks and Fisheries in the Arctic-Yukon-Kuskokwim Region of the Bering Sea, Alaska, 2001 and Outlook for 2002. Regional Information Report No. 3A02-01. Alaska Department of Fish and Game, Division of Commercial Fisheries, Anchorage.

DuBois, L. 2003. Age, Sex, and Size Compositions of Pacific Herring from Coastal Spawning Sites in the Arctic-Yukon-Kuskokwim Region, 2002. Regional Information Report No. 3A0303. Alaska Department of Fish and Game, Division of Commercial Fisheries, Anchorage.

Duffield, J., D. Patterson, and C. Neher. 2007. Revised Final Report. Economics of Wild Salmon Watersheds: Bristol Bay, Alaska. Trout Unlimited, Anchorage. 
Duffy-Anderson, J.T., M.S. Busby, K.L. Mier, C.M. Deliyanides, and P.J. Stabeno. 2006. "Spatial and Temporal Patterns in Summer Ichthyoplankton Assemblages on the Eastern Bering Sea Shelf 1996-2000." Fisheries Oceanography 15(1):80-94.

Dunaway, D.O., and S. Sonnichsen. 2001. Area Management Report for Recreational Fisheries of the Southwest Fisheries Management Area, 1999. Fisheries Management Report No. 01-6. Alaska Department of Fish and Game, Division of Sport Fish, Dillingham.

Dye, J.E., C.J. Schwanke, and T.A. Jaecks. 2006. Report to the Alaska Board of Fisheries for the Recreational Fisheries of Bristol Bay, 2004, 2005, and 2006. Special Publication No. 0629. Alaska Department of Fish and Game, Division of Sport Fish and Commercial Fisheries, Anchorage.

Failor-Rounds, B. 2005. Bering Sea-Aleutian Islands Area State-Waters Groundfish Fisheries and Groundfish Harvest from Parallel Seasons in 2004. Fishery Management Report No. 0571. Alaska Department of Fish and Game, Division of Sport Fish and Commercial Fisheries, Anchorage.

Fall, J.A., and T. Krieg. 2006. An Overview of the Subsistence Fishery of the Bristol Bay Management Area. Alaska Department of Fish and Game, Division of Subsistence Fisheries, Juneau.

Farley, E.V., Jr., B. Wing, A. Middleton, J. Pohl, L. Hulbert, J. Moss, M. Trudel, E. Parks, T. Hamilton, C. Lagoudakis, and D. McCallum. 2003. 2002 Eastern Bering Sea (BASIS) Coastal Research (August-October 2002) on Juvenile Salmon. NPAFC Doc. 678, Auke Bay Laboratory, Alaska Fisheries Science Center, National Marine Fisheries Service, Juneau.

Finney, B.P., I. Gregory-Eaves, J. Sweetman, M.S.V. Douglas, and J.P. Smol. 2000. "Impacts of Climatic Change and Fishing on Pacific Salmon Abundance over the Past 300 Years." Science 290:795-799.

Flint, P., and A.K. Miles. 2002. Relationships Between Boat Harbors, Fish Processing, Organic Contamination, and Steller's Eiders Wintering in the Eastern Aleutian Islands and Alaska Peninsula. U.S. Fish and Wildlife Service, Anchorage.

Flynn, L., and R. Hilborn. 2004. "Test Fishery Indices for Sockeye Salmon (Oncorhynchus nerka) as Affected by Age Composition and Environmental Variables." Canadian Journal of Fisheries and Aquatic Science 61(1):80-92.

Flynn, L., R. Hilborn, and A.E. Punt. 2003. "Identifying the Spatial Distribution of Stocks of Migrating Adult Sockeye Salmon Using Age Composition Data." Alaska Fishery Research Bulletin 10(1):50-60.

FWS. See U.S. Fish and Wildlife Service. 
Gharrett, A.J., A.K. Gray, and V. Brykov. 2001. "Phylogeographic Analysis of Mitochondrial DNA Variation in Alaskan Coho Salmon, Oncorhynchus kisutch." Fishery

Bulletin 99(4):528-544.

Gillispie, J.A.G. 1997. The Biology and Ecology of Arctic Cod. University of Alaska, Fairbanks.

Gravel, K.A., L.J. Watson, and D. Pengilly. 2006. The 2005 Eastern Bering Sea Snow Crab Chionoecetes opilio Tagging Study. Fishery Management Report No. 06-31. Alaska Department of Fish and Game, Division of Sport Fish and Commercial Fisheries, Anchorage.

Gunderson, D.R. 1996a. "Theragra chalcogramma: Distribution and Abundance in Shelikof Strait: What Can We Learn from Acoustic Survey Results?” In R.D. Brodeur, P.A. Livingston, T.R. Loughlin, and A.B. Hollowed (eds.), Ecology of Juvenile Walleye Pollock, Theragra chalcogramma. NOAA Technical Report NMFS 126, National Oceanic and Atmospheric Administration, National Marine Fisheries Service, Seattle, Washington.

Gunderson, D.R. 1996b. “Theragra chalcogramma: Summary and Recommendations for Future Research. In R.D. Brodeur, P.A. Livingston, T.R. Loughlin, and A.B. Hollowed (eds.), Ecology of Juvenile Walleye Pollock, Theragra chalcogramma. NOAA Technical Report NMFS 126, National Oceanic and Atmospheric Administration, National Marine Fisheries Service, Seattle, Washington.

Hammond, T.R., G.L. Swartzman, and T.S. Richardson. 2001. "Bayesian Estimation of Fish School Cluster Composition Applied to a Bering Sea Acoustic Survey." ICES Journal of Marine Science 58(6):1133-1149.

Hart, D.A., and P.G. van Tamelen. 2002. A Reference Guide to the Alaska Department of Fish and Game Shellfish Literature Library and Database. Special Publication No. 16. Alaska Department of Fish and Game, Division of Commercial Fisheries, Juneau.

Hoff, G.R. 2000. "Biology and Ecology of Threaded Sculpin, Gymnocanthus pistilliger, in the Eastern Bering Sea.” Fishery Bulletin 98(4):711-722.

Jackson, J.V. 2006. Alaska Peninsula-Aleutian Island Management Area Herring Sac Roe, Food and Bait Fisheries Management Report, 2005. Fishery Management Report No. 06-20. Alaska Department of Fish and Game, Division of Sport Fish and Commercial Fisheries, Anchorage.

Jackson, J.V., and A.D. Poetter. 2006. Alaska Peninsula-Aleutian Island Management Area Herring Sac Roe, Food and Bait Fisheries Management Report to the Alaska Board of Fisheries, 2006. Fishery Management Report No. 06-72. Division of Sport Fish and Commercial Fisheries, Anchorage.

Jewett, S.C. 1999. "Assessment of Red King Crabs Following Offshore Placer Gold Mining in Norton Sound." Alaska Fisheries Research Bulletin 6(1):1-18. 
Jewett, S.C., and A. Naidu. 2000. "Assessment of Heavy Metals in Red King Crabs Following Offshore Placer Gold Mining.” Marine Pollution Bulletin 40(6):478-490.

Jewett, S.C., X. Zhang, A.S. Naidu, J.J. Kelley, D. Dasher, and L.K. Duffy. 2003. "Comparison of Mercury and Methylmercury in Northern Pike and Arctic Grayling from Western Alaska Rivers." Chemosphere 50(3):383-392.

Johnson, J., and E. Weiss. 2006. A Catalogue of Waters Important for Spawning, Rearing, or Migration of Anadromous Fishes: Southwestern Region, Effective March 1, 2006. Special Publication No. 06-05. Alaska Department of Fish and Game and Alaska Department of Natural Resources, Juneau.

King, J.R. 2005. Report of the Study Group on Fisheries and Ecosystem Responses to Recent Regime Shifts. North Pacific Marine Science Organization, Sidney, British Columbia.

Logerwell, E.A., K. Aydin, S. Barbeaux, E. Brown, M.E. Conners, L. Lowe, J.W. Orr, I. Ortiz, R. Reuter, and P. Spencer. 2005. "Geographic Patterns in the Demersal Ichthyofauna of the Aleutian Islands." Fisheries Oceanography 14 (Suppl. 1): 93-112.

Loher, T., and D.A. Armstrong. 2005. "Historical Changes in Distribution and Abundance of Ovigerous Red King Crabs (Paralithodes camtschaticus) in Bristol Bay (Alaska) and Potential Relationship with Bottom Temperature." Fisheries Oceanography 14(4):292-306.

Loher, T., D.A. Armstrong, and B.G. Stevens. 2001. "Growth of Juvenile Red King Crab (Paralithodes camtschaticus) in Bristol Bay Elucidated from Field Sampling and TrawlSurvey Data." Fishery Bulletin 99:572-587.

Lovvren, J.R., L.W. Cooper, M.L. Brooks, C.C. De Ruyck, J.K. Bump, and J.M. Grebmeier. 2005. "Organic Matter Pathways to Zooplankton and Benthos under Pack Ice in Late Winter and Open Water in Late Summer in the North-Central Bering Sea Marine." Ecology Progress Series 291:135-150.

Lowe, S.A., and L. W. Fritz. 1997. “Atka Mackerel.” In Stock Assessment and Fishery Evaluation Report for Groundfish Resources in the Bering Sea/Aleutian Islands Region as Projected for 1998. North Pacific Fishery Management Council, Anchorage.

McDermott, S.F., L.W. Fritz, and V. Haist. 2005. "Estimating Movement and Abundance of Atka Mackerel (Pleurogrammus monopterygius) with Tag-Release-Recapture Data." Fisheries Oceanography 14 (Suppl. 1):113-130.

McNair, M., and R.R. Holder. 2000. Salmon Hatchery Releases by Release Site, 1964-1999: Arctic-Yukon-Kuskokwim. Regional Information Report 5J00-08. Alaska Department of Fish and Game, Division of Commercial Fisheries, Juneau. 
Mecklenburg, C.W., T.A. Mecklenburg, and L.K. Thorsteinson. 2002. Fishes of Alaska. American Fisheries Society, Bethesda, Maryland.

Megrey, B.A. 1996. "On the Relationship of Juvenile Walleye Pollock, Theragra chalcogramma, Abundance to Adult Recruitment and Linkages with the Environment." In R.D. Brodeur, P.A. Livingston, T.R. Loughlin, and A.B. Hollowed (eds.), Ecology of Juvenile Walleye Pollock, Theragra chalcogramma. NOAA Technical Report NMFS 126. National Oceanic and Atmospheric Administration, National Marine Fisheries Service, Seattle, Washington.

Merrick, R.L., and D.G. Calkins. 1996. "Importance of Juvenile Walleye Pollock, Theragra chalcogramma, in the Diet of Gulf of Alaska Steller Sea Lions, Eumetopias jubatus." In R.D. Brodeur, P.A. Livingston, T.R. Loughlin, and A.B. Hollowed, (eds.), Ecology of Juvenile Walleye Pollock, Theragra chalcogramma. NOAA Technical Report NMFS 126. National Oceanic and Atmospheric Administration, National Marine Fisheries Service, Seattle, Washington.

Meyers, T.R., J.F. Morado, A.K. Sparks, G.H. Bishop, T. Pearson, D. Urban, and D. Jackson. 1996. "Distribution of Bitter Crab Syndrome in Tanner Crabs (Chionoecetes bairdi, C. opilio) from the Gulf of Alaska and the Bering Sea." Diseases of Aquatic Organisms 26(3):221-227.

Minerals Management Service. 2004. A Study of the Drift Gillnet Fishery and Oil/Gas Industry Interactions and Mitigation Possibilities in Cook Inlet. OCS Study MMS 2004-038. U.S. Department of Interior, Minerals Management Service, Alaska Outer Continental Shelf Region, Anchorage.

MMS. See Minerals Management Service.

Moles, A., and B.L. Norcross. 1998. "Effects of Oil-Laden Sediments on Growth and Health of Juvenile Flatfishes." Canadian Journal of Fisheries and Aquatic Sciences 55:605-610.

Morstad, S., and T.T. Baker. 2006. Kvichak River Sockeye Salmon Stock Status and Action Plan: Report to the Alaska Board of Fisheries. Special Publication No. 06-26. Alaska Department of Fish and Game, Division of Sport Fish and Commercial Fisheries, Anchorage. Mueter, F.J., C. Ladd, M.C. Palmer, and B.L. Norcross. 2006. "Bottom-Up and Top-Down Controls on Walleye Pollack (Theragra chalcogramma) on the Eastern Bering Sea Shelf." Progress in Oceanography 68:152-183.

Mundy, P.R. 1998. Principles and Criteria for Sustainable Salmon Management: A Contribution to the Development of a Salmon Fishery Evaluation Framework for the State of Alaska. Fisheries and Aquatic Sciences, Lake Oswego, Oregon.

Murphy, R.L. 2005. North Alaska Peninsula Salmon Management Plan, 2005. Fishery Management Report No. 05-10. Alaska Department of Fish and Game, Anchorage, Alaska. 
Murphy, R.L., and P. Tschersich. 2005. North Alaska Peninsula Salmon Management Plan, 2006. Fishery Management Report No. 05-70. Alaska Department of Fish and Game, Anchorage.

Murphy, R.L., and P. Tschersich. 2006. The North Alaska Peninsula Fishery Salmon Report to the Alaska Board of Fisheries, 2007. Fishery Management Report No. 06-71. Alaska Department of Fish and Game, Division of Sport Fish and Commercial Fisheries, Anchorage.

Murphy, M.L., R.A. Heintz, J.W. Short, M.L. Larsen, and S.D. Rice. 1999. "Recovery of Pink Salmon Spawning Areas after the Exxon Valdez Oil Spill." Transactions of the American Fisheries Society 128:909-918.

Myers, K.W., R.V. Walker, H.R. Carlson, and J.H. Helle. 2000. "Synthesis and Review of U.S. Research on the Physical and Biological Factors Affecting Ocean Production of Salmon." North Pacific Anadromous Fish Commission Bulletin 2:1-9.

Napp, J.M., and G.L. Hunt, Jr. 2001. "Anomalous Conditions in the Southeastern Bering Sea 1997: Linkages among Climate, Weather, Ocean and Biology. Fisheries Oceanography 10:61-68.

Napp, J.M., A.W. Kendall, and J.D. Schumacher. 2000. "A Synthesis of Biological and Physical Processes Affecting the Feeding Environment of Larval Walleye Pollock (Theragra chalcogramma) in the Eastern Bering Sea." Fisheries Oceanography 9(2):147-162.

National Marine Fisheries Service. 2001. Endangered Species Act - Section 7: Consultation Biological Opinion and Incidental Take Statement/Authorization of Bering Sea-Aleutian Islands Groundfish Fisheries based on the Fishery Management Plan for the Bering SeaAleutian Islands Groundfish. U.S. Department of Commerce, National Oceanic and Atmospheric Administration, National Marine Fisheries Service, Juneau.

National Marine Fisheries Service. 2003. Supplement to the Endangered Species Act-Section 7: Biological Opinion and Incidental Take Statement of October 2001. U.S. Department of Commerce, National Oceanic and Atmospheric Administration, National Marine Fisheries Service, Juneau.

National Marine Fisheries Service. 2006. Alaska 2006 Draft Stock Summary Report, Revised Appendix 2, Stock Summary Table (last revised 5/15/06). National Marine Fisheries Service, Office of Protected Resources, Anchorage. Available at:

http://www.nmfs.noaa.gov/pr/pdfs/sars/ak2006_draft_summary.pdf (accessed August 1, 2007).

Nelson, P.A., J.J. Hasbrouck, M.J. Witteveen, K.A. Bouwens, and I. Vining. 2006. Review of Salmon Escapement Goals in the Alaska Peninsula and Aleutian Islands Management Areas Report to the Alaska Board of Fisheries, 2004. Fisheries Manuscript No. 06-03. Alaska Department of Fish and Game, Division of Sport Fish and Commercial Fisheries, Anchorage. 
NMFS. See National Marine Fisheries Service.

NPFMC. See North Pacific Fisheries Management Council.

North Pacific Fisheries Management Council. 2006. Available at:

http://www.fakr.noaa.gov/npfmc/default.htm (accessed on August 6, 2007).

O’Connell, M., M.C. Dillon, J.M. Wright, P. Bentzen, S. Merkouris, and J. Seeb. 1998.

"Genetic Structuring among Alaskan Pacific Herring Populations Identified Using

Microsatellite Variation." Journal of Fish Biology 53(1):150-163.

Olsen, J.B., S.E. Merkouris, and J.E. Seeb. 2002. "An Examination of Spatial and Temporal Genetic Variation in Walleye Pollock (Theragra chalcogramma) Using Allozyme, Mitochondrial DNA And Microsatellite Data." Fishery Bulletin 100(4):752-764.

Oswood, M.W., J.B. Reynolds, J.G. Irons, and A.M. Milner. 2000. "Distributions of Freshwater Fishes in Ecoregions and Hydroregions of Alaska." Journal of the North American Benthological Society 19(3):405-418.

Paul, A.J. 2000. Bibliography of Research on Snow Crab (Chionoecetes opilio). Publication No. AK-SG-00-01, Sea Grant College Program, University of Alaska, Fairbanks.

Paul, A.J., E.G. Dawe, R. Elner, G.S. Jamieson, G.H. Kruse, R.S. Otto, B. Sainte-Marie, T.C. Shirley, and D. Woodby. 2002. Crabs in Cold Water Regions: Biology, Management, and Economics. Pub. No. AK-SG-02-01. Sea Grant College Program, University of Alaska, Fairbanks.

Peterson, C.H. 2000. "The Exxon Valdez Oil Spill in Alaska: Acute, Indirect, and Chronic Effects on the Ecosystem." Advances in Marine Biology 39:3-84.

Rugolo, L.J., A.E. Chilton, C.E. Armistead, and J.A. Haaga. 2006. Report to Industry on the 2006 Eastern Bering Sea Crab Survey. AFSC Processed Report. 2006-17. Alaska Fisheries Science Center, National Marine Fisheries Service, Kodiak.

Salomone, P. 2006. Summary of Bristol Bay Sockeye Salmon Harvests by Gear Type, 20012006: A Report to the Alaska Board of Fisheries. Special Report No. 06-27. Alaska Department of Fish and Game, Division of Sport Fish and Commercial Fisheries, Anchorage.

Sands, T. 2006. Overview of the Bristol Bay Salmon Fishery, 2004-2006, A Report to the Alaska Board of Fisheries. Special Report No. 06-28. Alaska Department of Fish and Game, Division of Sport Fish and Commercial Fisheries, Anchorage.

Schabetsberger, R, R.D. Brodeur, T. Honkalehto, and K.L. Mier. 1999. "Sex-Biased Egg Cannibalism in Spawning Walleye Pollock: The Role of Reproductive Behavior." Environmental Biology of Fishes 54(2):175-190. 
Schumacher, J.D., and G.H. Kruse. 2005. "Toward Sustainable Ecosystem Services from the Aleutian Archipelago." Fisheries Oceanography 14 (Suppl. 1):277-291.

Seeb, L.W., and P.A. Crane. 1999. "High Genetic Heterogeneity in Chum Salmon in Western Alaska: The Contact Zone between Northern and Southern Lineages." Transactions of the American Fisheries Society 128(1):58-87.

Sepez, J.A., B.D. Tilt, C.L. Package, H.M. Lazarus, and I. Vaccaro. 2005. Community Profiles for North Pacific Fisheries - Alaska. NOAA Technical Memo, NMSF-AFSC-160. U.S. Department of Commerce, National Oceanic and Atmospheric Administration National Marine Fisheries Service, Seattle, Washington.

Spalinger, K. 2006. Bottom Trawl Survey of Crab and Groundfish: Kodiak, Chignik, South Peninsula, and Eastern Aleutians Management Districts, 2005. Fishery Management Report No. 06-43. Alaska Department of Fish and Game, Division of Sport Fish and Commercial Fisheries, Anchorage.

Stehn, R.A., K.S. Rivera, S. Fitzgerald, and K.D. Wohl. 2001. "Incidental Catch of Seabirds by Longline Fisheries in Alaska." pp. 61-77 in E. F. Melvin and J. K. Parrish (eds.), Proceedings - Seabird Bycatch: Trends, Roadblocks, and Solutions. University of Alaska Sea Grant College Program, Fairbanks.

Trudel, M. 2002. Prevalence and Intensity of Sea Lice (Lepeoptheirus salmonis) Infection on Juvenile Pink Salmon (Oncorhynchus gorbuscha) in the Bering Sea-September 2002. Ocean Sciences and Productivity Division, Fisheries and Oceans Canada, Pacific Biological Station, Nanaimo, British Columbia.

Tschersich, P. 2006. Annual Summary of the Commercial, Subsistence and Personal Use Salmon Fisheries and Salmon Escapements in the Alaska Peninsula, Aleutian Islands, and Atka-Amlia Islands Management Areas, 2005. Fishery Management Report 06-05. Alaska Department of Fish and Game, Anchorage.

Tschersich, P., and M.B. Foster. 2006. Alaska Peninsula and Aleutian Islands Management Areas Salmon Escapement and Catch Sampling Results, 2005. Fishery Management Report No. 06-28. Alaska Department of Fish and Game, Anchorage.

U.S. Fish and Wildlife Service. 1998. Biological Opinion on the Effects of the Bering Sea/Aleutian Islands and Gulf of Alaska Halibut Fishery on Short-tailed Albatross. U.S. Department of Interior, Fish and Wildlife Service, Anchorage.

U.S. Fish and Wildlife Service. 1999. Endangered Species Act Formal Section 7: Consultation for 1999-2000 Hook-and-Line Groundfish Fisheries of the Gulf of Alaska and Bering Sea and Aleutian Islands Area. U.S. Department of Interior, Fish and Wildlife Service, Anchorage. 
U.S. Fish and Wildlife Service. 2001. 2000 Fisheries Resource Monitoring Plan: Status Report to the Regional Advisory Councils and Federal Subsistence Board. U.S. Department of Interior, Fish and Wildlife Service, Federal Subsistence Management Program, Anchorage.

van Tamelen, P., and D. Woodby. 2003. Interagency Crab Research Meeting, December 1113, 2002. Regional Information Report No. 5J03-08. Alaska Department of Fish and Game, Division of Commercial Fisheries, Juneau.

Vining, I.W., and J. Zheng. 2006. Status of King Crab Stocks in the Eastern Bering Sea in 2005. Fishery Management Report No. 06-29. Alaska Department of Fish and Game, Anchorage.

Webb, J., and D. Woodby. 2006. Summary of the Interagency Crab Research Meeting Held December 14-16, 2005. Special Publication No. 06-08, Alaska Department of Fish and Game, Anchorage.

West, F.W. 2006. Bristol Bay Sockeye Salmon Inriver Test Fishing, 2005. Fishery Data Series No. 06-69. Alaska Department of Fish and Game, Division of Sport Fish and Commercial Fisheries, Anchorage.

West, F.W., and L.F. Fair. 2006. Abundance, Age, Sex, and Size Statistics for Pacific Salmon in Bristol Bay, 2003. Fishery Data Series No. 06-47, Alaska Department of Fish and Game, Division of Sport Fish and Commercial Fisheries, Anchorage.

Westing, C., S. Morstad, K.A. Wieland, T. Sands, L. Fair, F. West, and C. Brazil. 2005. Annual Management Report 2004 Bristol Bay Area. Fishery Management Report No 05-41. Alaska Department of Fish and Game, Division of Sport Fish and Commercial Fisheries, Anchorage.

Westing, C., C. Brazil, F. West, and T. Sands. 2006a. Review of the Togiak Herring Sac Roe and Spawn-on-Kelp Fisheries of Bristol Bay, Alaska: A Report to the Alaska Board of Fisheries. Special Publication No. 06-25. Alaska Department of Fish and Game, Division of Sport Fish and Commercial Fisheries, Anchorage.

Westing, C., T. Sands, S. Morstad, P. Salomone, L. Fair, F. West, C. Brazil, and K.A. Weiland. 2006b. Annual Management Report 2005 Bristol Bay Area. Fishery Management Report No. 06-37. Alaska Department of Fish and Game, Division of Sport Fish and Commercial Fisheries, Anchorage.

Williams, N. 1998. “Temperature Rise Could Squeeze Salmon.” Science 280:1349.

Williams, E.H. 1999. Interrelationships of Pacific Herring, Clupea pallasi Populations and Their Relation to Large-Scale Environmental and Oceanographic Variables. Thesis, University of Alaska, Fairbanks. 
Williams, E.H., and T.J. Quinn II. 1998. "A Parametric Bootstrap of Catch-Age Compositions Using the Dirichlet Distribution.” pp. 371-384 in F. Funk et al. (eds.), Fishery Stock Assessment Models, Proceedings of the International Symposium on Fishery Stock Assessment Models for the 21st Century. University of Alaska Sea Grant College Program, Anchorage.

Witherell, D. 1999. "Incorporating Ecosystem Considerations in to Management of Bering Sea Groundfish Fisheries.” Lowell Wakefield Fisheries Symposia Series 1999:315-327.

Wolfe, R.J., and C.J. Utermohl. 2000. Wild Food Consumption Rates Estimates for Rural Alaska Populations. Technical Paper No. 261. Alaska Department of Fish and Game, Division of Subsistence, Juneau.

Wyllie-Escheverria, T. 1997. Sea Ice and Fish Distribution on A Sub-Arctic Shelf. Ph.D. Dissertation. University of Alaska, Fairbanks, Alaska.

Wyllie-Escheverria, T., and K. Ohtani. 1999. "The Role of Ice in Organizing the Bering Sea Ecosystem." pp. 435-451 in T.R. Loughlin and K. Ohtani (eds.), Dynamics of the Bering Sea. University of Alaska Sea Grant AK-SG-99-03, Fairbanks.

Wyllie-Escheverria, T., and W.S. Wooster. 1998. "Year-to-Year Variations in Bering Sea Ice Cover and Some Consequences for Fish Distributions." Fisheries Oceanography 7(2):159-170.

Zheng, J. 2003. Evaluation of Alternative Harvest Strategies for Bristol Bay King Crabs. Regional Information Report No. 5J03-04. Alaska Department of Fish and Game, Division of Commercial Fisheries, Juneau.

Zheng, J., and G.H. Kruse. 2005. "Ecosystem Effects on Bering Sea Crabs Populations." Presentation at Promoting a Strong Economy and a Healthy Ecosystem, Crab and Halibut. Pribilof Islands Collaborative, September 14-16, 2005, Anchorage. Available at: http://www.worldwildlife.org/beringsea_erbc/ppt/GordonKruse_Crab.pdf (accessed August 1, 2007).

Zheng, J. and G.H. Kruse. 2006. "Recruitment Variation of Eastern Bering Sea Crabs: Climate Forcing or Top-Down Effects?" Progress on Oceanography 68:184-204.

\subsection{SEABIRDS, SHOREBIRDS, AND WATERFOWL}

ADFG. See Alaska Department of Fish and Game.

ADNR. See Alaska Department of Natural Resources. 
Agler, B.A., and S.J. Kendall. 1997. Marine Bird and Sea Otter Population Abundance of Prince William Sound, Alaska: Trends Following the T/V Exxon Valdez Oil Spill. Exxon Valdez Oil Spill Restoration Final Report, Project No. 96159. U.S. Fish and Wildlife Service, Anchorage.

Ainley, D.G., D.N. Nettleship, H.R. Carter, and A.E. Storey. 2002. "Common Murre (Uria aalge)." In A. Poole and F. Gill (eds.), The Birds of North America. The Birds of North America, Inc., Philadelphia, Pennsylvania.

Alaska Department of Fish and Game. 1997a. MESA 18, Walrus Islands. Alaska Department of Fish and Game, Habitat and Restoration Division, Anchorage.

Alaska Department of Fish and Game. 1997b. MESA 19, Nushagak Bay. Alaska Department of Fish and Game, Habitat and Restoration Division, Anchorage.

Alaska Department of Fish and Game. 1997c. MESA 20, Kvichak Bay. Alaska Department of Fish and Game, Habitat and Restoration Division, Anchorage.

Alaska Department of Fish and Game. 1997d. MESA 21, Egigik Bay. Alaska Department of Fish and Game, Habitat and Restoration Division, Anchorage.

Alaska Department of Fish and Game. 1997e. MESA 22, Ugashik Bay. Alaska Department of Fish and Game, Habitat and Restoration Division, Anchorage.

Alaska Department of Fish and Game. 1997f. MESA 23, Cinder River. Alaska Department of Fish and Game, Habitat and Restoration Division, Anchorage.

Alaska Department of Fish and Game. 1997g. MESA 24, Port Heiden. Alaska Department of Fish and Game, Habitat and Restoration Division, Anchorage.

Alaska Department of Fish and Game. 1997h. MESA 38, Kujulik Bay. Alaska Department of Fish and Game, Habitat and Restoration Division, Anchorage.

Alaska Department of Natural Resources. 2000. "Bristol Bay, Alaska Contingency Plan Subarea, 2000 Seabird Populations." Alaska Department of Natural Resources, Anchorage. Available at: http://www.asgdc.state.ak.us/maps/cplans/bristol/bb3seabird.pdf (accessed August 1, 2007).

Alaska Maritime National Wildlife Refuge. 2006. Website for annual Breeding Status and Population Trends of Seabirds in Alaska reports. Available at:

http://alaskamaritime.fws.gov/whatwedo/bioprojects/publications.htm (accessed on August 6, 2007).

Alaska Natural Heritage Program. 2005. Kittlitz's Murrelet. Environmental and Natural Resources Institute, University of Alaska, Anchorage.

Alaska Regional Response Team. 2001. "Sensitive Areas.” In Bristol Bay Subarea Contingency Plan for Oil and Hazardous Substance Discharge Releases. Alaska Department of 
Environmental Conservation, U.S. Coast Guard, and U.S. Environmental Protection Agency, Anchorage.

Alaska Shorebird Working Group. 2000. U.S. Shorebird Conservation Plan: A Conservation Plan for Alaska Shorebirds. Version I. U.S. Fish and Wildlife Service and U.S. Geological Survey, Anchorage.

ARRT. See Alaska Regional Response Team.

BLM. See Bureau of Land Management.

Bureau of Land Management. 2005. "Appendix D: Endangered and Threatened Species Consultation and Final Biological Assessment." In Northeast National Petroleum Reserve Alaska, Final Amended IAP/EIS. U.S. Department of Interior, Bureau of Land Management, Anchorage.

Bustnes, J.O., M. Asheim, T.H. Bjǿrn, H. Gabrielsen, and G.H. Systad. 2000. "The Diet of Steller's Eiders Wintering in Varangerfjord, Northern Norway." Wilson Bulletin 112:8-13.

Byrd, G.V., and D.E. Dragoo. 1997. Breeding Success and Population Trends of Selected Seabirds in Alaska in 1996. Fish and Wildlife Service Report AMNWR 97/11. U.S. Fish and Wildlife Service, Alaska Maritime National Wildlife Refuge, Homer.

Byrd, G.V., H.M. Renner, and M. Renner. 2005. Distribution Patterns and Population Trends of Breeding Seabirds in the Aleutian Islands. Fisheries Oceanography 14 (Suppl. 1):139-159.

Causey, D., D.G. Corbett, C. Fefevre, D.L. West, A. Savinetsky, M.K. Kiseleva, and B. Khassanov. 2005. "The Palaeoenvironment of Humans and Marine Birds of the Aleutian Islands: Three Millennia of Change." Fisheries Oceanography 14 (Suppl. 1):259-276.

Center for Biological Diversity et al. 2001. Petition to List the Kittlitz's Murrelet (Brachyramphus brevirostris) as Endangered under the Endangered Species Act. Center for Biological Diversity Coastal Coalition, Eyak Preservation Council, Lynn Canal Conservation, Inc., and Sitka Conservation Society. Available at: http://www.biologicaldiversity.org/swcbd/species/murrelet/Petition.pdf (accessed August 1, 2007).

Christopher, S.J., S.S. Vander Pol, R.S. Pugh, R.D. Day, and P.R. Becker. 2002. "Determination of Mercury in the Eggs of Common Murres (Uria aalge) for the Seabird Tissue Archival and Monitoring Project." Journal of Analytical Atomic Spectrometry 17:780-785.

Circumpolar Seabird Working Group. 1997. Circumpolar Eider Conservation Strategy and Action Plan. Available at: http://arcticportal.org/uploads/WC/0x/WC0xEbzLwdbFA7mv8SsnOA/ CircumpolarEiderStrategyandActionPlan.pdf (accessed August 1, 2007). 
Dau, C.P., and E.J. Mallek. 2006. Aerial Survey of Emperor Geese and Other Waterbirds in Southwestern Alaska, Spring 2006. U.S. Fish and Wildlife Service, Migratory Bird Management Office, Anchorage.

Dau, C.P., P.L. Flint, and M.R. Peterson. 2000. "Distribution of Recoveries of Steller's Eiders Banded on the Lower Alaska Peninsula, Alaska." Journal of Field Ornithology 71:541-548.

Day, R.H., and D.A. Nigro. 2000. "Feeding Ecology of Kittlitz's and Marbled Murrelets in Prince William Sound, Alaska.” Waterbirds 23:1-14.

Day, R.H., and D.A. Nigro. 2003. "Is the Kittlitz's Murrelet Exhibiting Reproductive Problems in Prince William Sound, Alaska?" Waterbirds 27:89-95.

Day, R.H., S.M. Murphy, J.A. Wiens, G.D. Hayward, E.J. Harner, and B.E. Lawhead. 1997a. "Effects of the Exxon Valdez Oil Spill on Habitat Use by Birds along the Kenai Peninsula, Alaska." Condor 99:728-742.

Day, R.H., S.M. Murphy, J.A. Wiens, G.D. Hayward, E.J. Harner, and L.N. Smith. 1997b. "Effects of the Exxon Valdez Oil Spill on Habitat Use by Birds in Prince William Sound, Alaska." Ecological Applications 7:593-613.

Day, R.H., K.J. Kuletz, and D.A. Nigro. 1999. "Kittlitz's Murrelet Brachyramphus brevirostris." In A. Poole and F. Gill (eds.), The Birds of North America. The Birds of North America, Inc., Philadelphia, Pennsylvania.

Day, R.H., D.A. Nigro, and A.K. Prichard. 2000. “At-Sea Habitat Use by the Kittlitz's Murrelet Brachyramphus brevirostris in Nearshore Waters of Prince William Sound, Alaska." Marine Ornithology 28:105-114.

Day, R.H., A.K. Prichard, and D.A. Nigro. 2003a. "Ecological Specialization and Overlap of Brachyramphus Murrelets in Prince William Sound, Alaska.” Auk 120:680-699.

Day, R.H., J.R. Rose, J.R. Ritchie, J.E. Shook, and B.A. Cooper. 2003b. Collision Potential of Eiders and Other Birds near a Proposed Windfarm at St. Lawrence Island, October-November 2002. ABR Environmental Research and Services, Fairbanks.

Day, R.H., A.K. Pritchard, and J.R. Rose. 2005a. Migration and Collision Avoidance of Eiders and Other Birds at Northstar Island, Alaska, 2001-2004: Final Report. BP Exploration Alaska, Anchorage.

Day, R.H., J.R. Rose, A.K. Pritchard, R.J. Blaha, and B.A. Cooper. 2005b. "Environmental Effects on the Fall Migration of Eiders at Barrow, Alaska." Marine Ornithology 32:13-24.

Department of Commerce. 1997. "Fisheries of the Exclusive Economic Zone off Alaska; Management Measures to Reduce Seabird Bycatch in the Hook-and-Line Groundfish Fisheries." 
U.S. Department of Commerce, National Oceanic and Atmospheric Administration, National Marine Fisheries Service. Federal Register 62:65635-65638.

Department of Commerce. 1998. "Halibut Fisheries in U.S. Convention Waters off Alaska; Fisheries of the Exclusive Economic Zone off Alaska; Management Measures to Reduce Seabird Bycatch in the Hook-and-Line Halibut and Groundfish Fisheries." U.S. Department of Commerce, National Oceanic and Atmospheric Administration, National Marine Fisheries Service. Federal Register 63(44):11161-11167.

Department of Defense. 1999. Final Environmental Impact Statement-Beaufort Sea Oil and Gas Development: Northstar Project. U.S. Army Corps of Engineers, Anchorage.

Department of Interior. 1997. "Final Rule for Threatened Status for the Alaska Breeding Population of the Steller's Eider." U.S. Department of Interior, Fish and Wildlife Service. Federal Register 62:31748-31757.

Department of Interior. 2000. "Proposed Designation of Critical Habitat for Spectacled Eider." U.S. Department of Interior, Fish and Wildlife Service. Federal Register 65:13262-13284.

Department of Interior. 2001a. "Endangered and Threatened Wildlife and Plants; Final Determination of Critical Habitat for the Spectacled Eider." U.S. Department of Interior, Fish and Wildlife Service. Federal Register 66(25):9145-9185.

Department of Interior. 2001b. "Final Determination of Critical Habitat for the Alaska-Breeding Population of Steller's Eider.” U.S. Department of Interior, Fish and Wildlife Service. Federal Register 66(25):8850-8884.

Department of Interior. 2001c. "Final Rule to Remove the Aleutian Canada Goose from the Federal List of Endangered and Threatened Wildlife." U.S. Department of Interior, Fish and Wildlife Service. Federal Register 66(54):15643-15656.

Department of Interior. 2003. "Availability of the Recovery Plan for the Alaska Breeding Population of the Steller's Eider (Polysticta stelleri).” U.S. Department of Interior, Fish and Wildlife Service. Federal Register 68 (78):20020-20021.

Department of Interior. 2005a. "The Seabird Tissue Archival and Monitoring Project (STAMP)." U.S. Department of Interior, Fish and Wildlife Service, U.S. Geological Survey. Available at: http://www.absc.usgs.gov/research/ammtap/stamp.htm (accessed August 2, 2007).

Department of Interior. 2005b. "Wetlands Digital Data." U.S. Department of Interior, Fish and Wildlife Service, Branch of Habitat Assessment, National Wetland Inventory. Available at: http://wetlandsfws.er.usgs.gov/ (accessed August 2, 2007).

DOC. See Department of Commerce.

DOD. See Department of Defense. 
DOI. See Department of Interior.

Dragoo, D.E., G.V. Byrd, and D.B. Irons. 2000. Breeding Status and Population Trends of Seabirds in Alaska in 1999. Fish and Wildlife Service Report AMNWR 00/02. U.S. Department of Interior, Fish and Wildlife Service, Alaska Maritime National Wildlife Refuge, Homer.

Dragoo, D.E., G.V. Byrd, and D.B. Irons. 2003. Breeding Status, Population Trends and Diets of Seabirds in Alaska, 2001. Fish and Wildlife Service Report AMNWR 03/05. U.S. Department of Interior, Fish and Wildlife Service, Alaska Maritime National Wildlife Refuge, Homer.

Dragoo, D.E., G.V. Byrd, and D.B. Irons. 2004. Breeding Status, Population Trends, and Diets of Seabirds in Alaska, 2002. Fish and Wildlife Service Report AMNWR 04/15. U.S. Department of Interior, Fish and Wildlife Service, Alaska Maritime National Wildlife Refuge, Homer.

Drew, G.S., and J.F. Piatt. 2005a. North Pacific Pelagic Seabird Database (NPPSD): Compiling Datasets and Creating an Archive, Accessible Database, and Pelagic Seabird Atlas. Final report for the North Pacific Marine Research Institute, Report No. NPMRI 18. U.S. Department of Interior, U.S. Geological Survey, Alaska Science Center, Anchorage.

Drew, G.S., and J.F. Piatt. 2005b. "Surveying the Past: North Pacific Pelagic Seabird Database." Keynote address in Marine Science in Alaska: 2004 Symposium. Available at: http://www.absc.usgs.gov/research/NPPSD/MSS2005.ppt (accessed August 2, 2007).

Esler, D., J.A. Schmutz, R.L. Jarvis, and D.M. Mulcahy. 2000. "Winter Survival of Adult Harlequin Ducks in Relation to History of Contamination by the Exxon Valdez Oil Spill." Journal of Wildlife Management 64: 839-847.

Esler, D., T.D. Bowman, K.A. Trust, B.E. Ballachev, T.A. Dean, S.C. Jewett, and C.E. O'Clair. 2002. "Harlequin Duck Population Recovery Following the 'Exxon Valdez' Oil Spill: Progress, Process and Constraints." Marine Ecology Progress Series 241:271-286.

Estes, J.A., B.C. Bacon, W.M. Jarman, R.J. Norstrom, R.G. Anthony, and A.K. Miles. 1997. "Organochlorines in Sea Otters and Bald Eagles from the Aleutian Archipelago." Marine Pollution Bulletin 34(6):486-492.

Flint, P.L., and A.C. Fowler. 1998. "A Drift Experiment to Assess the Influence of Wind on Recovery of Oiled Sea Birds on St. Paul Island, Alaska." Marine Pollution Bulletin 36(2):165-166.

Flint, P., and A.K. Miles. 2002. Relationships between Boat Harbors, Fish Processing, Organic Contamination, and Steller's Eiders Wintering in the Eastern Aleutian Islands and Alaska Peninsula. Progress Report Prepared for U.S. Fish and Wildlife Service, Anchorage.

Flint, P.L., M.R. Petersen, and J. B. Grand. 1997. "Exposure of Spectacled Eiders and Other Diving Ducks to Lead in Western Alaska." Canadian Journal of Zoology 75:439-443. 
Flint, P.L., J.B. Grand, and R.F. Rockwell. 1998. "Modeling Northern Pintail Productivity and Population Growth Rate." Journal of Wildlife Management 62:1110-1118.

Flint, P.L., A.C. Fowler, and R.F. Rockwell. 1999. "Modeling Bird Mortality Associated With the M/V Citrus Oil Spill off St. Paul Island, Alaska.” Ecological Modelling 117:261-267.

Flint, P.L., M.R. Petersen, C.P. Dau, J.E. Hines, and J.D. Nichols. 2000. "Annual Survival and Site Fidelity of Steller's Eiders along the Alaska Peninsula." Journal of Wildlife Management 64:261-268.

Flint, P.L., D.L. Lacroix, J.A. Reed, and R.B. Lanctot. 2004. "Movements of Flightless LongTailed Ducks during Wing Molt." Waterbirds 27:35-40.

Fowler, A.C., and P.L. Flint. 1997. "Persistence Rates and Detection Probabilities of Oiled King Eider Carcasses on St. Paul Island, Alaska.” Marine Pollution Bulletin 34(7):522-526.

Fredrickson, L.H. 2001. "Steller's Eider (Polysticta stelleri)." In A. Poole and F. Gill (eds.), The Birds of North America. The Birds of North America, Inc., Philadelphia, Pennsylvania.

FWS. See U.S. Fish and Wildlife Service.

Gaston, A.J., and J.M. Hipfner. 2000. "Thick-Billed Murre (Uria lomvia).” In A. Poole and F. Gill (eds.), The Birds of North America. The Birds of North America, Inc., Philadelphia, Pennsylvania.

Gilchrist, H.G. 2001. "Glaucous Gull (Larus hyperboreus). In A. Poole and F. Gill (eds.), The Birds of North America. The Birds of North America, Inc., Philadelphia, Pennsylvania.

Gill, B. 2004. Summaries of Ongoing or New Studies of Alaska Shorebirds during 2003. U.S. Geological Survey, Alaska Science Center, Anchorage.

Gill, R.E., Jr., and B.J. McCaffery. 1999. "Bar-Tailed Godwits Limosa lapponica in Alaska: A Population Estimate from the Staging Grounds.” Wader Study Group Bulletin 88:49-54.

Gill, R.E., Jr., and S.E. Senner. 1996. "Alaska and Its Importance to Western Hemisphere Shorebirds." International Wader Studies 8:8-14.

Golet, G.H., P.E. Seiser, A.D. McGuire, D.D. Roby, J.B. Fischer, K.J. Kuletz, D.B. Irons, T.A. Dean, S.C. Jewett, and S.H. Newman. 2002. "Long-Term Direct and Indirect Effects of the Exxon Valdez Oil Spill on Pigeon Guillemots in Prince William Sound, Alaska." Marine Ecology Progress Series 241:287-304.

Goudie, R.I., G.J. Robertson, and A. Reed. 2000. "Common Eider (Somateria mollissima)." In A. Poole and F. Gill (eds.), The Birds of North America. The Birds of North America, Inc., Philadelphia, Pennsylvania. 
Grand, J.B., P.L. Flint, M.R. Petersen, and C.L. Moran. 1998. "Effect of Lead Poisoning on Spectacled Eider Survival Rates.” Journal of Wildlife Management 62:1103-1109.

Grand, J.B., J.C. Franson, P.L. Flint, and M.R. Peterson. 2002. "Concentrations of Trace Elements in Eggs and Blood of Spectacled and Common Eiders in the Yukon-Kuskokwim Delta, Alaska, USA.” Environmental Toxicology and Chemistry 21(8):1673-1678.

Guillemette, M. 1998. "The Effect of Time and Digestion Constraints in Common Eiders while Feeding and Diving over Blue Mussel Beds.” Functional Ecology 12:123-131.

Guillemette, M. 2001. "Foraging Before Spring Migration and before Breeding in the Common Eider: Does Hyperphagia Occur?” Condor 103:633-638.

Handel, C.M., and R.E. Gill. 2000. "Mate Fidelity and Breeding Site Tenacity in a Monogamous Sandpiper, the Black Turnstone.” Animal Behaviour 60:471-481.

Handel, C.M., and R.E. Gill. 2001. "Black Turnstone (Arenaria melanocephala).” In A. Poole and F. Gill (eds.), The Birds of North America. The Birds of North America, Inc., Philadelphia, Pennsylvania.

Harding, A.M.A., J.F. Piatt, G.V. Byrd, S.A. Hatch, N.B. Konyukov, E.U. Golubova, and J.C. Williams. 2005. "Variability in Colony Attendance of Crevice-Nesting Horned Puffins, Implications for Population Monitoring." Journal of Wildlife Management 69 (3):1279-1296.

Hatch, S.A., P.M. Meyers, D.M. Mulcahy, and D.C. Douglas. 1996. Seasonal Movements and Pelagic Habitat Use of Murres and Puffins Determined by Satellite Telemetry. Restoration Project 95021, Final Report. U.S. Department of Interior, National Biological Service, Anchorage.

Hatch, S.A., P.M. Meyers, D.M. Mulcahy, and D.C. Douglas. 2000. "Seasonal Movements and Pelagic Habitat Use of Murres and Puffins Determined by Satellite Telemetry." Condor 102(1):145-154.

Hobson, K.A. 1997. "Pelagic Cormorant (Phalacrocorax pelagicus)." In A. Poole and F. Gill (eds.), The Birds of North America. The Birds of North America, Inc., Philadelphia, Pennsylvania.

Hodges, J.I., J.G. King, B. Conant, and H.A. Hanson, 1996. Aerial Surveys of Waterbirds in Alaska 1957-94: Population Trends and Observer Variability. Information and Technology Report 4. U.S. Department of Interior, National Biological Service, Anchorage.

Hunt, G.L. Jr., H. Kato, and S.M. McKinnell. 2001. Predation by Marine Birds and Mammals in the Subarctic North Pacific Ocean. PICES Scientific Report No. 14 (2000). North Pacific Marine Science Organization, Sydney, British Columbia. 
Hunt, G.L., Jr., G.S. Drew, J. Jahncke, and J.F. Piatt. 2005. "Prey Consumption and Energy Transfer by Marine Birds in the Gulf of Alaska.” Deep Sea Research II 52:781-797.

Irons, D.B., S.J. Kendall, W.P. Erickson, L.L. McDonald, and B.K. Lance. 2000. "Nine Years after the Exxon Valdez Oil Spill: Effects on Marine Bird Populations in Prince William Sound, Alaska." Condor 102: 723-737.

Jahncke, J., K.O. Coyle, and G.L. Hunt, Jr. 2005. "Seabird Distribution, Abundance and Diets in the Eastern and Central Aleutian Islands." Fisheries Oceanography 14 (Suppl. 1):160-177.

Jones, I.L., N.B. Konyukhov, J.C. Williams, and G.V. Byrd, 2001. "Parakeet Auklet (Aethia psittacula)." In A. Poole and F. Gill (eds.), The Birds of North America. The Birds of North America, Inc., Philadelphia, Pennsylvania.

Kitaysky, K.S., E.V. Kitaiskaia, J.F. Piatt, and J.C. Wingfield. 2006. “A Mechanistic Link between Chick Diet and Decline in Seabirds?" Proceedings of the Royal Society B 273:445-450.

Kucklick, J. R., S.S. Vander Pol, P.R. Becker, R.S. Pugh, K. Simac, G.W. York, and D.G. Roseneau. 2002. "Persistent Organic Pollutants in Murre Eggs from the Bering Sea and Gulf of Alaska.” Organohalogen Compounds 59:13-16.

Kuletz, K.J. 2004. Kittlitz's Murrelet: A Glacier Bird in Retreat. U.S. Department of Interior, Fish and Wildlife Service, Anchorage.

Kuletz, K.J., S.W. Stephenson, D.B. Irons, E.A. Labunski, and K.M. Brenneman. 2003. "Changes in Distribution and Abundance of Kittlitz's Murrelet Brachyramphus brevirostris relative to Glacial Recession in Prince William Sound, Alaska." Marine Ornithology 31:133-140.

Lacroix, D.L., R.B. Lanctot, J.A. Reed, and T.L. McDonald. 2003. "Effect of Underwater Seismic Surveys on Molting Male Long-Tailed Ducks in the Beaufort Sea, Alaska." Canadian Journal of Zoology 81:1862-1875.

Ladd, C., J. Hahncke, G.L. Hunt Jr., K.O. Coyle, and P.J. Stabeno. 2005. “Hydrographic Features and Seabird Foraging in Aleutian Passes." Fisheries Oceanography 14 (Suppl. 1):178-195.

Lance, B.K., D.B. Irons, S.J. Kendall, and L.L. McDonald. 2001. “An Evaluation of Marine Bird Population Trends Following the Exxon Valdez Oil Spill, Prince William Sound, Alaska." Marine Pollution Bulletin 42:298-309.

Lanctot, R., B. Goatcher, K. Scribner, S. Talbot, B. Pierson, D. Esler, and D. Zwiefelhofer. 1999. "Harlequin Duck Recovery from the Exxon Valdez Oil Spill: A Population Genetics Perspective." Auk 116:781-791. 
Larned, W.W. 1998. Aerial Surveys to Evaluate King Eider Molting Areas Detected by Satellite Telemetry in Western Alaska, 1998. Progress Report. U.S. Fish and Wildlife Service, Migratory Bird Management-Waterfowl Branch, Anchorage.

Larned, W.W. 2000a. Aerial Surveys of Steller's Eiders and Other Waterbirds and Marine Mammals in Southwest Alaska Areas Proposed for Navigation Improvements by the U.S. Army Corps of Engineers, Alaska. U.S. Fish and Wildlife Service, Kenai.

Larned, W.W. 2000b. Steller's Eider Spring Migration Surveys, Southwest Alaska, 2000. U.S. Fish and Wildlife Service, Migratory Bird Management Office, Anchorage.

Larned, W.W. 2002. Steller's Eider Spring Migration Surveys, Southwest Alaska, 2002. U.S. Fish and Wildlife Service, Migratory Bird Management Office, Anchorage.

Larned, W.W. 2003. Steller's Eider Spring Migration Surveys, Southwest Alaska, 2003. U.S. Fish and Wildlife Service, Migratory Bird Management Office, Anchorage.

Larned, W.W. 2004. Steller's Eider Spring Migration Surveys, Southwest Alaska, 2004. U.S. Fish and Wildlife Service, Migratory Bird Management Office, Anchorage.

Larned, W.W. 2005. Steller's Eider Spring Migration Surveys-Southwest Alaska, 2005. U.S. Fish and Wildlife Service, Migratory Bird Management Office, Anchorage.

Larned, W.W.. and T. Tiplady. 1997. Late Winter Population and Distribution of Spectacled Eiders (Somateria fischeri) in the Bering Sea, 1996-97. U.S. Fish and Wildlife Service, Migratory Bird Management Office, Anchorage.

Larned, W.W., and T.J. Tiplady. 1999. Late Wintering Distribution of Spectacled Eiders (Somateria fischeri) in the Bering Sea 1998. U.S. Fish and Wildlife Service, Migratory Bird Management, Anchorage.

Laubhan, M.K., and K.A. Metzner. 1999. "Distribution and Diurnal Behavior of Steller's Eiders Wintering on the Alaska Peninsula." Condor 101:694-698.

Litzow, M.A., J.F. Piatt, A. K. Prichard, and D.D. Roby. 2002. "Response of Pigeon Guillemots to Variable Abundance of High-Lipid and Low-Lipid Prey." Oecologia 132(2):286-295.

Lovvorn, J.R., J.M. Grebmeier, and L.W. Cooper. 2000. "Effects of Possible Changes in the St. Lawrence Island Polynya on a Top Benthic Predator: the Spectacled Eider." ARCUS 12th Annual Meeting and Arctic Forum 2000, Washington D.C. Available at:

http://www.arcus.org/annual_meetings/2000/posters.html (accessed August 2, 2007).

Lovvorn, J.R., S.E. Richman, J.M. Grebmeier, and L.W. Cooper. 2003. "Diet and Body Condition of Spectacled Eiders Wintering in Pack Ice of the Bering Sea." Polar Biology 26:259-267. 
Mallek, E.J., and C.P. Dau. 2004. Aerial Survey of Emperor Geese and other Waterbirds in Southwestern Alaska, Fall 2004. U.S. Fish and Wildlife Service, Migratory Bird Management Office, Anchorage.

Mallek, E.J., and C.P. Dau. 2005. Aerial Survey of Emperor Geese and other Waterbirds in Southwestern Alaska, Fall 2005. U.S. Fish and Wildlife Service, Migratory Bird Management Office, Anchorage.

McCaffery, B.J., and Gill, R.E. 2001. "Bar-tailed Godwit (Limosa lapponica)." In A. Poole and F. Gill (eds.), The Birds of North America. The Birds of North America, Inc., Philadelphia, Pennsylvania.

Meehan, R., G.V. Byrd, G.J. Divoky, and J.F. Piatt. 1999. "Implications of Climate Change for Alaska's Seabirds." In G. Weller and P.A. Anderson (eds.), Assessing the Consequences of Climate Change for Alaska and the Bering Sea Region, Proceedings of a Workshop at the University of Alaska Fairbanks, 29-30 October 1998. University of Alaska, Fairbanks.

Melvin, E.F., M.D. Wainstein, K.S. Dietrich, K.L. Ames, T.O. Geernaert, and L.L. Conquest. 2006. The Distribution of Seabirds on the Alaskan Longline Fishing Grounds: Implications for Seabird Avoidance Regulations. Washington Sea Grant Program, University of Washington, Seattle, Washington.

Murphy, S.M., R.H. Day, J.A. Wiens, and K.R. Parker. 1997. "Effects of the Exxon Valdez Oil Spill on Birds: Comparisons of Pre- and Post-Spill Surveys in Prince William Sound, Alaska." Condor 99:299-313.

Pearce, J.M., S.L. Talbot, M.R. Petersen, and J.R. Rearick. 2005. "Limited Genetic Differentiation among Breeding, Molting, and Wintering Groups of the Threatened Steller's Eider: The Role of Historic and Contemporary Factors." Conservation Genetics 6:743-757.

Petersen, M.R., and D.C. Douglas. 2004. "Winter Ecology of Spectacled Eiders: Environmental Characteristics and Population Change." Condor 106:79-94.

Petersen, M.R., and P.L. Flint. 2002. "Population Structure of Pacific Common Eiders Breeding in Alaska." Condor 104:780-787.

Petersen, M.R., J.F. Piatt, and K.A. Trust. 1998. "Foods of Spectacled Eiders Somateria fischeri in the Bering Sea, Alaska." Wildfowl 49:124-128.

Petersen, M.R., W.W. Larned, and D.C. Douglas. 1999. "At-Sea Distribution of Spectacled Eiders: A 120-Year-Old Mystery Resolved.” Auk 116:1009-1020.

Piatt, J., and G. Drew. 2004. Preliminary Assessment of Marine Bird Abundance and Species Composition in the Vicinity of the Selendang Ayu Grounding, Based on Historical Data from the North Pacific Pelagic Seabird Database. U.S. Geological Survey, Alaska Science Center, Anchorage. 
Piatt, J.F., and R.G. Ford. 2000a. A Computerized Pelagic Seabird Atlas for Alaska.

U.S. Geological Survey, Biological Resources Division, Anchorage.

Piatt, J.F., and R.G. Ford. 2000b. Monitoring Seabird Populations in Areas of Oil and Gas Development on the Alaskan Continental Shelf: A Computerized Pelagic Seabird Atlas for Alaska. OCS Study MMS 2000-072. U.S. Department of Interior, Minerals Management Service, Anchorage.

Piatt, J.F., and A.S. Kitaysky. 2002. "Horned Puffin (Fratercula corniculata)." In A. Poole and F. Gill (eds.), The Birds of North America. The Birds of North America, Inc., Philadelphia, Pennsylvania.

Piatt, J.F., and A.M. Springer. 2004. "Advection, Pelagic Food Webs and the Biogeography of Seabirds in Beringia." Marine Ornithology 31:141-154.

Piatt, J.F., G.S. Drew, and D.B. Irons. 2006. Atlas of Seabird Distribution at Sea. U.S. Geological Survey, Alaska Science Center and U.S. Fish and Wildlife Service, Anchorage.

Richman, S.E., and J.R. Lovvorn. 2003. "Effects of Clam Species Dominance on Nutrient and Energy Acquisition by Spectacled Eiders in the Bering Sea." Marine Ecology Progress Series 261:283-297.

Robertson, G.J., and J.P. Savard. 2002. "Long-tailed Duck (Clangula hyemalis).” In A. Poole and F. Gill (eds.), The Birds of North America. The Birds of North America, Inc., Philadelphia, Pennsylvania.

Russell, R.W. 2005. Interactions between Migrating Birds and Offshore Oil and Gas Platforms in the Northern Gulf Of Mexico: Final Report. U.S. Department of Interior, Minerals Management Service, New Orleans, Louisiana.

Schauer, J.H.S., and E.C. Murphy. 1996. "Predation on Eggs and Nestlings of Common Murres (Uria aalge) at Bluff, Alaska.” Colonial Waterbirds 19(2):186-198.

Sea Duck Joint Venture. 2003. Steller's Eider (Polysticta stelleri). Sea Duck Information Series, Information Sheet 13 of 15. Sea Duck Joint Venture, Anchorage.

Solovieva, D.V. 1999. Biology and Bioenergetics of the Steller's Eider (Polysticta stelleri). Ph.D. Dissertation. University of Saint Petersburg, Saint Petersburg, Russia.

Springer, A.M., J.F. Piatt, and G.V. Van Vliet. 1996. "Sea Birds as Proxies of Marine Habitats and Food Webs in the Western Aleutian Arc." Fisheries Oceanography 5:45-55.

Stehn, R.A., K.S. Rivera, S. Fitzgerald, and K. Wohl 2001. "Incidental Catch of Seabirds by Longline Fisheries in Alaska." pp. 61-77 in E.F. Melvin and J.K. Parrish (eds.), Proceedings-Seabird Bycatch: Trends, Roadblocks, and Solutions. University of Alaska Sea Grant College Program, Fairbanks. 
Stephenson, S.W., and D.B. Irons. 2003. "Comparison of Colonial Breeding Seabirds in the Eastern Bering Sea and Gulf of Alaska.” Marine Ornithology 31:167-173.

Stout, J.H. 2002. "Environmental Contaminants in Four Eider Species from Alaska and Arctic Russia." Environmental Pollution 119:215-226.

Suydam, R.S. 2000. "King Eider (Somateria spectabilis).” In A. Poole and F. Gill (eds.), The Birds of North America. The Birds of North America, Inc., Philadelphia, Pennsylvania.

Systad, G.H., and J.O. Bustnes. 2001. "Coping with Darkness and Low Temperatures: Foraging Strategies in Steller's Eiders, Polysticta stelleri, Wintering at High Latitudes." Canadian Journal of Zoology 79(3):402-406.

Trust, K.A., K.T. Rummel, A.M. Scheuhammer, I.L. Brisbin, Jr., and M.J. Hooper. 2000. "Contaminant Exposure and Biomarker Responses in Spectacled Eiders (Somateria fischeri) from St. Lawrence Island, Alaska." Archives of Environmental Contamination and Toxicology 38:107-113.

U.S. Fish and Wildlife Service. 1996a. Catalog of Alaska Seabird Colonies-Computer Archives. U.S. Department of Interior, Fish and Wildlife Service, Anchorage.

U.S. Fish and Wildlife Service. 1996b. Spectacled Eider Recovery Plan. U.S. Department of Interior, Fish and Wildlife Service, Anchorage.

U.S. Fish and Wildlife Service. 1999a. Endangered Species Act Formal Section 7 Consultation for 1999-2000 Hook-and-Line Groundfish Fisheries of the Gulf of Alaska and Bering Sea and Aleutian Islands Area. U.S. Department of Interior, Fish and Wildlife Service, Anchorage.

U.S. Fish and Wildlife Service. 1999b. Population Status and Trends of Sea Ducks in Alaska. U.S. Department of Interior, Fish and Wildlife Service, Migratory Bird Management, Anchorage.

U.S. Fish and Wildlife Service. 2000. Biological Opinion Regarding the Effects of Harbor Construction at False Pass, Alaska, on the Threatened Steller's Eider (Polysticta stelleri). U.S. Department of Interior, Fish and Wildlife Service, Anchorage.

U.S. Fish and Wildlife Service. 2001. Short-tailed Albatross (Phoebastria albatrus).

U.S. Department of Interior, Fish and Wildlife Service, Anchorage.

U.S. Fish and Wildlife Service. 2002. Steller's Eider Recovery Plan. U.S. Department of Interior, Fish and Wildlife Service, Fairbanks.

U.S. Fish and Wildlife Service. 2004a. Steller's Eider Spring Migration Surveys Southwest Alaska. U.S. Department of Interior, Fish and Wildlife Service, Anchorage. 
U.S. Fish and Wildlife Service. 2004b. "Critical Habitat Map. U.S. Department of Interior, Fish and Wildlife Service, Anchorage." Available at:

http://alaska.fws.gov/media/StellEider_CHMap.htm (accessed August 12, 2006).

Vander Pol, S.S., P.R. Becker, J.R. Kucklick, R.S. Pugh, D.G. Roseneau, K. Simac, and G.W. York. 2003. Trends in Concentrations of Persistent Organic Pollutants in Eggs from Alaskan Murre Colonies. Second AMAP International Symposium on Environmental Pollution of the Arctic, Rovaniemi, Finland.

Vlietstra, L.K., O. Coyne, N.B. Kachel, and G.L. Hunt, Jr. 2005. "Tidal Front Affects the Size of Prey Used by a Top Marine Predator, the Short-Tailed Shearwater (Puffinus tenuirostris)." Fisheries Oceanography 14 (Suppl. 1):196-211.

Ward, D.H., R.A. Stehn, W.P. Erickson, and D.V. Derksen. 1999. "Response of Fall Staging Brant and Canada Geese to Aircraft Overflights in Southwestern Alaska." Journal of Wildlife Management 63:373-381.

Wiese, F.K., and G.J. Robertson. 2004. "Assessing Seabird Mortality from Chronic Oil Discharges at Sea." Journal of Wildlife Management 68:627-638.

Wiese, F.K., W.A. Montevecchi, G.K. Davoren, F. Huetmann, A.W. Diamond, and J. Linke. 2001. "Seabirds at Risk around Offshore Oil Platforms in the North-West Atlantic." Marine Pollution Bulletin 42:1285-1290.

Wilbor, S.L. 1999. Status Report on the Bering Sea/Pacific Oldsquaw (Clangula hyemalis) Population. Environment and Natural Resources Institute, University of Alaska, Anchorage.

Wilson, H.M., M.R. Petersen, and D.M. Troy. 2004. "Concentrations of Metals and Trace Elements in Blood of Spectacled and King Eiders in Northern Alaska, USA." Environmental Toxicology and Chemistry 23(2):408-414.

Winker, K., and D.A. Rocque. 2004. Seabird Samples as Resources for Marine Environmental Assessment. OCS Study MMS 2004-035. University of Alaska Fairbanks and U.S. Department of Interior, Minerals Management Service, Anchorage.

York, G.W., B.J. Porter, R.S. Pugh, D.G. Roseneau, K. Simac, P.R. Becker, L.K. Thorsteinson, and S.A. Wise. 2001. Seabird Tissue Archival and Monitoring Project: Protocol for Collecting and Banking Seabird Eggs. OCS Study MMS 2001-031. U.S. Department of Interior, Minerals Management Service, Anchorage.

\subsection{MARINE MAMMALS}

ADFG. See Alaska Department of Fish and Game. 
Agler, B.A., and S.J. Kendall. 1997. Marine Bird and Sea Otter Population Abundance of Prince William Sound, Alaska: Trends Following the T/V Exxon Valdez Oil Spill. Exxon Valdez Oil Spill Restoration Final Report. Project No. 96159. U.S. Fish and Wildlife Service, Anchorage.

Alaska Department of Fish and Game. 1997a. MESA 18, Walrus Islands. Alaska Department of Fish and Game, Habitat and Restoration Division, Anchorage.

Alaska Department of Fish and Game. 1997b. MESA 19, Nushagak Bay. Alaska Department of Fish and Game, Habitat and Restoration Division, Anchorage.

Alaska Department of Fish and Game. 1997c. MESA 20, Kvichak Bay. Alaska Department of Fish and Game, Habitat and Restoration Division, Anchorage.

Alaska Department of Fish and Game. 1997d. MESA 21, Egigik Bay. Alaska Department of Fish and Game, Habitat and Restoration Division, Anchorage.

Alaska Department of Fish and Game. 1997e. MESA 22, Ugashik Bay. Alaska Department of Fish and Game, Habitat and Restoration Division, Anchorage.

Alaska Department of Fish and Game. 1997f. MESA 23, Cinder River. Alaska Department of Fish and Game, Habitat and Restoration Division, Anchorage.

Alaska Department of Fish and Game. 1997g. MESA 24, Port Heiden. Alaska Department of Fish and Game, Habitat and Restoration Division, Anchorage.

Alaska Department of Fish and Game. 1997h. MESA 38, Kujulik Bay. Alaska Department of Fish and Game, Habitat and Restoration Division, Anchorage.

Alaska Fisheries Science Center. 2006. Publications Database Search. Available at: http://access.afsc.noaa.gov/pubs/search.cfm (accessed on August 6, 2007).

Alaska Science Center. 2004. "Pacific Walrus Research, Alaska Science Center - Biological Science Office: Data Products." U.S. Department of Interior, U.S. Geological Survey, Alaska Science Center, Anchorage. Available at: http://alaska.usgs.gov/science/biology/ (accessed on August 6, 2007).

Alaska Sea Life Center. 2006. "Alaska Sea Life Center - Research" website. Available at: http://www.alaskasealife.org/New/research/index.php?page=firstpage.php (accessed on August 6, 2007).

American Cetacean Society. 2004. Pacific White-Sided Dolphin Leganorhyncus obliquidens. Fact sheet. American Cetacean Society, San Pedro, California.

American Cetacean Society. 2005a. Dall's Porpoise Phocoenoides dalli. Fact sheet. American Cetacean Society, San Pedro, California. 
American Cetacean Society. 2005b. Harbor Porpoise Phocoena phocoena. Fact sheet. American Cetacean Society, San Pedro, California.

Angliss, R., and R.B. Outlaw. 2005. Alaska Marine Mammal Stock Assessments, 2005. NOAA Technical Memorandum NMFS-AFSC-161. National Oceanic and Atmospheric Administration, National Marine Fisheries Service, Alaska Fisheries Science Center, Seattle, Washington.

Angliss, R.P., G.K. Silber, and R. Merrick. 2002. Report of a Workshop on Developing Recovery Criteria for Large Whale Species. NOAA Technical Memorandum NMFS-F/OPR-21. U.S. Department of Commerce, National Oceanic and Atmospheric Administration, National Marine Fisheries Service, Office of Protected Resources, Anchorage.

Antonelis, G.A., E.H. Sinclair, R.R. Ream, and B.W. Robson. 1997. "Inter-Island Variation in the Diet of Female Northern Fur Seals (Callorhinus ursinus) in the Bering Sea." Journal of Zoology (London) 242:435-451.

Baker, A.R., T.R. Loughlin, V. Burkanov, C.W. Matson, R.G. Trujillo, D.G. Calkins, J.K. Wickliffe, and J.W. Bickham. 2005. "Variation of Mitochondrial Control Region Sequences of Steller Sea Lions: The Three-Stock Hypothesis. ” Journal of Mammalogy 86(6):1075-1084.

Bengtson, J.L., P.L. Boveng, V. Burkanov, D.P. DeMaster, K.J. Frost, and L.F. Lowry. 1999. "Life History of Arctic Seals: Do Apex Predators Reflect Inter-Decadal Changes in the Bering Sea Ecosystems?" pp. 11-13 in NOAA's Arctic Research Initiative: The First Three Years. U.S. Department of Commerce, National Oceanic and Atmospheric Administration, Office of Oceanic and Atmospheric Research, Arctic Research Office, Silver Spring, Maryland.

Brownell, R.L., P.J. Clapham, T. Miyashita, and T. Kasuya. 2001. "Conservation Status of North Pacific Right Whales.” Journal of Cetacean Research and Management, Special Issue 2:269-286.

Brueggeman, J.J. 1998. "Marine Mammal Habitat Use on the North Aleutian Basin, St. George Basin, and Gulf of Alaska." pp. 97-108 in L.E. Jarvela and L.K. Thorsteinson (eds.), Proceedings of the Gulf of Alaska, Cook Inlet, and North Aleutian Basin Information Update Meeting. U.S. Department of Commerce, National Oceanic and Atmospheric Administration, Office of Ocean and Marine Assessments, Anchorage.

Buckland, S.T., and J.M. Breiwick. 2002. "Estimated Trends in Abundance of Eastern Pacific Gray Whales from Shore Counts (1967/68 to 1995/96)." Journal of Cetacean Research and Management 4(1):41-48.

Burek, K.A., M.D. Frances, G.S. Gulland, G. Sheffield, K.B. Beckmen, E. Keyes, T.R. Spraker, A.W. Smith, D.E. Skilling, J.F. Evermann, J.L. Stott, J.T. Saliki, and A.W. Trites. 2005. "Infectious Disease and the Decline of Steller Sea Lions (Eumetopias jubatus) in Alaska, USA: Insights from Serologic Data.” Journal of Wildlife Diseases 41(3):512-524. 
Burn, D.M. 1998. "Estimation of Hunter Compliance with the Marine Mammal Marking, Tagging, and Reporting Program for Walrus.” Wildlife Society Bulletin 26(1):68-74.

Burn, D.M. and W.L. Perryman. 1999. "Application of Remote Sensing to Walrus Studies in Alaska." In 13th Biennial Conference on the Biology of Marine Mammals, Wailea, Hawaii. Society for Marine Mammalogy, Orlando, Florida.

Burn, D.M., M. Webber, and M. Udevitz. 2003. "Application of Airborne Thermal Remote Sensing to Surveys of Pacific Walrus (Odobenus rosmarus divergens)." In 15th Biennial Conference on the Biology of Marine Mammals, Greensboro, North Carolina. Society for Marine Mammalogy, Orlando, Florida.

Butterworth, D.S., D.L. Borchers, and A.E. Punt. 2002a. "Dynamic Response Analysis for the Eastern North Pacific Gray Whale Population: An Alternative Approach." Journal of Cetacean Research and Management 4(1):77-83.

Butterworth, D.S., J.L. Korrübel, and A.E. Punt. 2002b. "What is Needed to Make a Simple Density-Dependent Response Population Model Consistent with Data for the Eastern North Pacific Gray Whales?" Journal of Cetacean Research and Management 4(1):63-76.

Calambokidis, J., G.H. Steiger, J.R. Evenson, K.R. Flynn, K.C. Balcomb, D.E. Claridge, P. Bloedel, J.M. Straley, C.S. Baker, O. von Ziegesar, M.E. Dahlheim, J.W. Waite, J.D. Darling, G. Ellis, and G.A. Green. 1996. "Interchange and Isolation of Humpback Whales off California and Other North Pacific Feeding Grounds.” Marine Mammal Science 12(2):215-226.

Calkins, D.G., E.F. Becker, and K.W. Pitcher. 1998. "Reduced Body Size of Female Steller Sea Lions from a Declining Population in the Gulf of Alaska." Marine Mammal Science $14(2): 232-244$.

Call, K.A., and T.R. Loughlin. 2005. "An Ecological Classification of Alaskan Steller Sea Lion (Eumetopias jubatus) Rookeries: A Tool for Conservation/Management.” Fisheries Oceanography 14 (Suppl. 1):212-222.

Cascadia Research. 2006. "Structure of Populations, Levels of Abundance, and Status of Humpbacks (SPLASH).” Cascadia Research, Olympia, Washington. Project website available at: www.cascadiaresearch.org/SPLASH/splash.htm (accessed on August 6, 2007).

Castellini, M.A., B. Fadely, L. Jemison, B. Kelly, J. Lewis, L. Lowry, G. O’Corry-Crowe, G. Pendleton, K. Pitcher, U. Swain, K. Wynne, and R. Zarnke. 1996. Annual Report - Harbor Seal Investigations in Alaska. NOAA Grant NA57FX0367. Alaska Department of Fish and Game, Division of Wildlife Conservation, Juneau.

Chadwick, V.J., B.E. Ballachey, S.M. Arthur, G.W. Garner, and D.M. Mulcahy. 1996. "Preliminary Research on Pacific Walrus to Evaluate Potential Effects of Disturbance by OCS Related Oil and Gas Activities in the Chukchi Sea." pp. 151-158 in Proceedings of the 1995 
Arctic Synthesis Meeting, Anchorage, Alaska. U.S. Department of Interior, Minerals Management Service, Alaska OCS Region, Anchorage.

Chivers, S.J. 1999. "Biological Indices for Monitoring Population Status of Walrus Evaluated with an Individual-Based Model." In Garner et al. (eds.), Marine Mammal Survey and Assessment Methods. Balkema, Rotterdam, The Netherlands.

Chivers, S.J., A.E. Dizon, P.J. Gearin, and K.M. Robertson. 2002. "Small-Scale Population Structure of Eastern North Pacific Harbour Porpoises (Phocoena phocoena) Indicated by Molecular Genetic Analyses." Journal of Cetacean Research and Management 4(2):111-122.

Clark, C.W., and W.T. Ellison. 2000. "Calibration and Comparison of the Acoustic Location Methods Used during the Spring Migration of the Bowhead Whale, Balaena mysticetus, off Point Barrow, Alaska, 1984-1993." Journal of the Acoustical Society of America 107(6):3509-3517.

Clarke, J.T., and S.E. Moore. 2002. "A Note on Observations of Gray Whales in the Southern Chukchi and Northern Bering Seas, August-November, 1980-89." Journal of Cetacean Research and Management 4(3):283-288.

Clark, C.W., R. Charif, S. Mitchell, and J. Colby. 1996. "Distribution and Behavior of the Bowhead Whale, Balaena mysticetus, Based on Analysis of Acoustic Data Collected during the 1993 Spring Migration off Point Barrow, Alaska." Report of the International Whaling Commission 46:541-552.

Coffing, M., C.L. Scott, and C. J. Utermohle. 1998. The Subsistence Harvest of Seals and Sea Lions by Alaska Natives in Three Communities of the Yukon-Kuskokwim Delta, Alaska, 1997-98. Technical Paper No. 255. Alaska Department of Fish and Game, Division of Subsistence, Juneau.

Coffing, M., C.L. Scott, and C.J. Utermohle. 1999. The Subsistence Harvest of Seals and Sea Lions by Alaska Natives in Three Communities of the Yukon-Kuskokwim Delta, Alaska, 1998-99. Technical Paper No. 255. Alaska Department of Fish and Game, Division of Subsistence, Juneau.

Coombs, A.P., A.W. Trites, and D. Pauly. 2003. "Assessing Impacts of Contaminants on Marine Mammals and Human Health in the Eastern Bering Sea." In 15th Biennial Conference on the Biology of Marine Mammals, Greensboro, North Carolina. Society for Marine Mammalogy, Orlando, Florida.

Da Silva, C.Q., J. Zeh, D. Madigan, J. Laake, D. Rugh, W. Baraff, W. Koski, and G. Miller. 2000. "Capture-Recapture Estimation of Bowhead Whale Population Size Using PhotoIdentification Data." Journal of Cetacean Research and Management 2(1):45-61. 
Dahlheim, M.E., A. York, R. Towell, J. Waite, and J. Breiwick. 2000. "Harbor Porpoise (Phocoena phocoena) Abundance in Alaska: Bristol Bay to Southeast Alaska, 1991-1993." Marine Mammal Science 16(1):28-45.

Dehn, L.A., G. Sheffield, E.H. Follmann, G.R. Bratton, V.M. Woshner, P.F. Hoekstra, and T.M. O'Hara. 2002. "Feeding Ecology of Arctic Phocids: Implications for Heavy Metal Dynamics." In 53rd Arctic Science Conference, Connectivity in Northern Waters. American Association for the Advancement of Science, Arctic Division, Fairbanks.

Dehn, L.A., G. Sheffield, E.H. Follmann, L.K. Duffy, V.M. Woshner, and T.M. O’Hara. 2003. "Age and Diet Related Distribution of Heavy Metals in Renal and Hepatic Tissue of Ringed, Bearded, and Spotted Seals Harvested in Alaska." In 15th Biennial Conference on the Biology of Marine Mammals Greensboro, North Carolina. Society for Marine Mammalogy, Orlando, Florida.

DeMaster, D.P., D.J. Rugh, B. Jones, L.F. Lowry, K.J. Frost, and G. Sheffield. 1996.

"Summaries of Data Collected from Ice-Associated Seals in the Bering, Chukchi, and Beaufort Seas, 1975-1991." pp. 213-213 in P.S. Hill and D.P. DeMaster (eds.), Marine Mammal Protection Act and Endangered Species Act Implementation Program 1996. National Marine Mammal Laboratory, Seattle, Washington.

DeMaster, D.P., J.M. Waite, K.J. Frost, and L.F. Lowry 1997. "Distribution and Abundance of Ringed Seals in Northern Alaska, May 1996." in P.S. Hill and D.P. DeMaster (eds.), Marine Mammal Protection Act and Endangered Species Act Implementation Program 1996. National Marine Mammal Laboratory, Seattle, Washington.

DeMaster, D.P, L.F. Lowry, K.J. Frost, and R.A. Bengtson. 2001. "The Effect of Sea State on Estimates of Abundance for Beluga Whales (Delphinapterus leucas) in Norton Sound." Alaska Fishery Bulletin 99(1):197-201.

Department of Commerce. 2002. "Endangered and Threatened Species; Final Determination on a Petition to Designate Critical Habitat for the Bering Sea Stock of Bowhead Whales." National Oceanic and Atmospheric Administration. Federal Register 67(169):55767-55771.

Department of Commerce. 2006. "Endangered and Threatened Species; Revision of Critical Habitat for the Northern Right Whale in the Pacific Ocean." National Oceanographic and Atmospheric Administration. Federal Register 71(129):38277-38297.

Department of Defense. 1999. Final Environmental Impact Statement-Beaufort Sea Oil and Gas Development: Northstar Project. U.S. Army Engineer District, Anchorage.

Department of Interior. 2000. "Notice of Designation of the Northern Sea Otter in the Aleutian Islands as a Candidate Species." U.S. Department of Interior, Fish and Wildlife Service. Federal Register 65(218):67343-67345.

DOC. See Department of Commerce. 
DOD. See Department of Defense.

DOI. See Department of Interior.

Eberhardt, L.L., J.L. Sease, and D.P. Demaster. 2005. "Projecting the Trend of Steller Sea Lion Populations in Western Alaska." Marine Mammal Science 21(4):728-738.

Estes, J.A., C.E. Bacon, W.M. Jarman, R.J. Norstrom, R.G. Anthony, and A.K. Miles. 1997. "Organochlorines in Sea Otters and Bald Eagles from the Aleutian Archipelago." Marine Pollution Bulletin 34(6):486-492.

Evans, T.J., D.M. Burn, and A.R. DeGange. 1997. Distribution and Relative Abundance of Sea Otters in the Aleutian Archipelago. Technical Report MMM 97-5. U.S. Department of Interior, Fish and Wildlife Service, Anchorage.

Fadely, B.S., B.W. Robson, J.T. Sterling, A. Greig, K.A. Call. 2005. "Immature Steller Sea Lion (Eumetopias jubatus) Dive Activity in Relation to Habitat Features of the Eastern Aleutian Islands." Fisheries Oceanography 14 (Suppl. 1):243-258.

Fay, F.H., L.L. Eberhardt, B.P. Kelly, J.J. Burns, and L.T. Quakenbush. 1997. "Status of the Pacific Walrus Population, 1950-1989.” Marine Mammal Science 13(4):537-565.

Fedoseev, G.A. 2000. Population Biology of Ice-Associated Forms of Seals and Their Role in the Northern Pacific Ecosystems. Coronet Books, Philadelphia, Pennsylvania.

Ferrero, R.C. 1996. Growth Patterns of the Pacific White-sided Dolphin in the Central North Pacific. AFSC Quarterly Report, October-November-December 1996. National Oceanic and Atmospheric Administration, National Marine Fisheries Service, Alaska Fisheries Science Center, Seattle, Washington.

Ferrero, R.C., and W.A. Walker. 1996. "Age, Growth, and Reproductive Patterns of Pacific White-Sided Dolphin (Lagenorhynchus obliquidens) Taken in High Seas Driftnets in the Central North Pacific Ocean." Canadian Journal of Mammalogy 74:1673-1687.

Folkens, P. 2003. "Global Climate Change and Implications for Marine Mammal Survival." In 15th Biennial Conference on the Biology of Marine Mammals, Greensboro, North Carolina. Society for Marine Mammalogy, Orlando, Florida.

Forney, K.A., and R.L. Brownell, Jr. 1996. Preliminary Report of the 1994 Aleutian Island Marine Mammal Survey. International Whaling Commission Scientific Committee, Aberdeen, Scotland.

Fritz, L.W., and S. Hinckley. 2005. "A Critical Review of the Regime Shift-'Junk Food'Nutritional Stress Hypothesis for the Decline of the Western Stock of the Steller Sea Lion." Marine Mammals Science 21(3):476-518. 
FWS. See U.S. Fish and Wildlife Service.

Garlich-Miller, J.L. 1997. Age, Sex, and Reproductive Status of Pacific Walrus Harvested in the Bering Strait Region, 1994-1996. Technical Report MMM 97-1. U.S. Department of Interior, Fish and Wildlife Service, Region 7, Marine Mammals Management, Anchorage.

Garlich-Miller, J.L., and D.M. Burn. 1999. "Estimating the Harvest of Pacific Walrus, Odobenus rosmarus divergens, in Alaska." Fishery Bulletin 97(4):1043-1046.

Garlich-Miller, J.L., and C.V. Jay. 2000. Proceedings of a Workshop Concerning Walrus Survey Methods, Anchorage, Alaska. U.S. Department of Interior, Fish and Wildlife Service, Marine Mammals Management, Anchorage, Alaska.

Garlich-Miller, J.L., and C. Pungowiyi. 1999. Proceedings of a Workshop Concerning Walrus Harvest Monitoring in Alaska and Chukotka. U.S. Department of Interior, Fish and Wildlife Service, Region 7, Anchorage.

Garlich-Miller, J.L., L.T. Quakenbush, and J.F. Bromaghin. 2006. "Trends in Age Structure and Productivity of Pacific Walruses Harvested in the Bering Strait Region of Alaska, 1952-2002." Marine Mammal Science 22(4):880-896.

Gelatt, T.S. 1996. Activity Patterns and Time Budgets of Sea Otters at Amchitka Island, Alaska. M.S. Thesis. University of Minnesota, Minneapolis.

George, J.C., D. Goering, M. Sturm, R. Elsner, and E. Follman, E. 2001. "Energetic Adaptations of the Bowhead Whales." 14th Biennial Conference on the Biology of Marine Mammals, Vancouver, Canada. Society for Marine Mammalogy, Orlando, Florida.

George, J.C., J.E. Zeh, R.S. Suydam, and R.S.C. Clark. 2002. Population Size of the BeringChukchi-Beaufort Seas Stock of Bowhead Whales, Balaena mysticetus, based on the 2001 Census off Point Barrow, Alaska. Paper presented to the International Whaling Commission Scientific Committee, Shimonski, Japan.

Givens, G.H. 2000. "Strike Limit Algorithm Optimization: A Realistic Example.” Journal of Cetacean Research and Management 2(1):75-83.

Givens, G.H. 2003. "Empirical Estimation of Safe Aboriginal Whaling Limits for Bowhead Whales." Journal of Cetacean Research and Management 5(1):39-43.

Givens, G.H., and M.V. Bravington. 1996. Confirmation, Revision and Sensitivity Analysis of the 1994 Scientific Committee Assessment of the Bering-Chukchi-Beaufort Seas Stock of Bowhead Whales. Report of the International Whaling Commission 46:501-507.

Goddard, P.D., and D.J. Rugh. 1998. "A Group of Right Whales Seen in the Bering Sea in July 1996." Marine Mammal Science 14(2):344-349. 
Greene, C.R., Jr., M.W. McLennan, R.G. Norman, T.L. McDonald, and W.J. Richardson. 2003. "Using DIFAR Sensors to Locate Calling Bowhead Whales and Monitor their Migration." 15th Biennial Conference on the Biology of Marine Mammals, Greensboro, North Carolina. Society for Marine Mammalogy, Orlando, Florida.

Gudmundson, C.J, T.K. Zeppelin, and R.T. Ream. 2006. "Application of Two Methods for Determining Diet of Northern Fur Seals (Callorhinus ursinus)." Fishery Bulletin 104(2):226-237.

Hastings, K.K. 2001. "Monitoring Contaminants in Alaskan Harbor Seals.” In Harbor Seal Investigations in Alaska. Annual Report for NOAA Award NA87FX0300. Alaska Department of Fish and Game, Division of Wildlife Conservation, Anchorage.

Hill, P.S., and D.P. DeMaster. 1999. Alaska Marine Mammal Stock Assessments, 1999. NOAA Technical Memorandum NMFS-AFSC-110. U.S. Department of Commerce, National Oceanic and Atmospheric Administration, National Marine Fisheries Service, Seattle, Washington.

Hill, P.S., D.P. DeMaster, and R.J. Small. 1997. Alaska Marine Mammal Stock Assessment 1996. NOAA Technical Memorandum NMFS-AFSC-78. U.S. Department of Commerce, National Oceanic and Atmospheric Administration, National Marine Fisheries Service, Seattle, Washington.

Hills, S. 2001. "Movements and Behavior of Male Pacific Walruses in Spring and Early Summer." 14th Biennial Conference on the Biology of Marine Mammals, Vancouver, Canada. Society for Marine Mammalogy, Orlando, Florida.

Hirons, A.C. 1996. "Trophic Relationships of Alaskan Pinnipeds in the Bering Sea and Gulf of Alaska as Indicated by Stable Carbon and Nitrogen Istopes." pp. 21-22 in Arctic Science Conference. Shaping an Unpredictable Future. Communities and Science, Girdwood, Alaska. Arctic Division, American Association for the Advancement of Science, Anchorage.

Hirons, A.C., D.M. Schell, and B.P. Finney. 2001. "Temporal Records of Delta C-13 and Delta N-15 in North Pacific Pinnipeds: Inferences Regarding Environmental Change and Diet." Oecologia 129(4):591-601.

Hobson, K.A., and J.L. Sease. 1998. "Stable Isotope Analyses of Tooth Annuli Reveal Temporal Dietary Records: An Example Using Steller Sea Lions." Marine Mammal Science 14(1):116-129.

Hoekstra, P.F., L.A. Dehn, J.C. George, K.R. Solomon, D.C.G. Muir, and T.M. O’Hara. 2002a. "Trophic Ecology of Bowhead Whales (Balaena mysticetus) Compared with that of other Arctic Marine Biota as Interpreted from Carbon-, Nitrogen-, and Sulfur-Isotope Signatures." Canadian Journal of Zoology 80(2):223-231. 
Hoekstra, P.F., T.M. O’Hara, S.J. Pallant, K.R. Solomon and D.G.S. Muir. 2002b. "Bioaccumulation of Organochlorine Contaminants in Bowhead Whales (Balaena mysticetus) from Barrow, Alaska." Archives of Environmental Contamination and Toxicology 42(4):497-507.

Houck, W.J., and T.A. Jefferson. 1999. "Dall's Porpoise (Phocoenoides dalli).” pp. 443-472 in S.H. Ridgeway and R. Harrison (eds.), Handbook of Marine Mammals, Vol. 6: The Second Book of Dolphins and Porpoises. Academic Press, San Diego, California.

Hunt, G.L., Jr., H. Kato, and S.M. McKinnell. 2001. Predation by Marine Birds and Mammals in the Subarctic North Pacific Ocean. PICES Scientific Report No. 14 (2000). North Pacific Marine Science Organization, Sydney, British Columbia.

International Whaling Commission. 2006. Report of the Scientific Committee Annual Meeting of 26 May-6 June, 2006, St. Kitts Nevis. International Whaling Commission, Cambridge, England.

Ivashchenko, Y., G. Tsidulko, A. Burdin, O. Sichenko, and Y. Lebedeva. 2003. "Reactions of Western Gray Whales to Seismic Surveys off Northeastern Sakhalin Island, Russia." In 15th Biennial Conference on the Biology of Marine Mammals, Greensboro, North Carolina. Society for Marine Mammalogy, Orlando, Florida.

Jamison, L.A. 2001. "Summary of Harbor Seal Diet Data Collected in Alaska from 1990-1999." In Harbor Seal Investigations in Alaska. Annual Report for NOAA Award NA87FX0300. Alaska Department of Fish and Game, Division of Wildlife Conservation, Anchorage. Jamison, L.A., G.W. Pendleton, and C.A. Wilson. 2001. "Harbor Seal Population Trends and Factors Influencing Counts in Nanvak Bay, Northern Bristol Bay, Alaska." In Harbor Seal Investigations in Alaska. Annual Report for NOAA Award NA87FX0300. Alaska Department of Fish and Game, Division of Wildlife Conservation, Anchorage.

Jay, C.V., T.L. Olson, G.W. Garner, and B.E. Ballachey. 1998. "Response of Pacific Walruses to Disturbances from Capture and Handling Activities at a Haulout in Bristol Bay, Alaska." Marine Mammal Science 14(4):819-828.

Kasuya, T. 2002. "Giant Beaked Whales.” pp. 519-522 in W.F. Perrin, B. Würsig, and J.G.M. Thewissen (eds), Encyclopedia of Marine Mammals. Academic Press, San Diego, California.

Kelly, B.P., B.D. Taras, and L.T. Quakenbush. 1999. "Pacific Walruses: Evidence of a Declining Population." In 13th Biennial Conference on the Biology of Marine Mammals, Wailea, Hawaii. Society for Marine Mammalogy, Orlando, Florida.

Kim, G.B., J.S. Lee, S. Tanabe, H. Iwata, R. Tatsukawa, and K. Shimazaki. 1996. "Specific Accumulation and Distribution of Butyltin Compounds in Various Organs and Tissues of the Steller Sea Lion (Eumetopias jubatus): Comparison with Organochlorine Accumulation Pattern." Marine Pollution Bulletin 32(7):558-563. 
Krahn, M.M., P.R. Becker, K.L. Tilbury, and J.E. Stein 1997. "Organochlorine Contaminants in Blubber of Four Seal Species: Integrating Biomonitoring and Specimen Banking."

Chemosphere 34(9/10):2109-2121.

Krahn, M.M., D.G. Burrows, J.E. Stein, P.R. Becker, M.M. Schantz, D.C.G. Muir, T.M. O’Hara, and T. Rowles. 1999. "White Whales (Delphinapterus leucas) from Three Alaskan Stocks:

Concentrations and Patterns of Persistent Organochlorine Contaminants in Blubber." Journal of Cetacean Research and Management (3):239-249.

Krahn, M.M., G.M. Ylitalo, D.B. Burrows, J. Calambokidis, S.E. Moore, M. Gosho, P. Gearin, P.D. Plesha, R.L.J. Brownell, S.A. Blokhin, K.L. Tilbury, T. Rowles, and J.E. Stein. 2001. "Organochlorine Contaminant Concentrations and Lipid Profiles in Eastern North Pacific Gray whales (Eschrichtius robustus)." Journal of Cetacean Research and Management 3(1):19-29.

Kucey, L., and A.W. Trites. 2006. "A Review of the Potential Effects of Disturbance on Sea Lions: Assessing Response and Recovery.” pp. 581-589 in A.W. Trites, S. Atkinson, D.P. DeMaster, L.W. Fritz, T.S. Gelatt, L.D. Rea, and K. Wynne (eds.), Sea Lions of the World. Alaska Sea Grant College Program, University of Alaska, Fairbanks.

Le Boeuf, B.J., H.M. Pérez-Cortés, R.J. Urbán, B.R. Mate, and U.F. Ollervides. 2000. "High Gray Whale Mortality and Low Recruitment in 1999: Potential Causes and Implications." Journal of Cetacean Research and Management 2(2):85-99.

LeDuc, R., W.L. Perryman, M. MacDonald, J. Hyde, and R.L. Brownell, Jr. 2000. Progress Report on the Eastern North Pacific Right Whale Research during July 1999.

Paper SC/52/OS13. International Whaling Commission. Cambridge, England.

LeDuc, R., W.L. Perryman, J.W. Gilpatrick, Jr., J. Hyde, C. Stinchcomb, J.V. Carretta, and R.L. Brownell, Jr. 2001. "A Note on Recent Surveys for Right Whales in the Southeastern Bering Sea." Journal of Cetacean Research and Management (Special Issue) 2:287-289.

LeDuc, R.G., D.W. Weller, J. Hyde, A.M. Burdin, P.E. Rosel, R.L. Brownell Jr., B. Würsig, and A.E. Dizon. 2002. "Genetic Differences between Western and Eastern North Pacific Gray Whales (Eschrichtius robustus)." Journal of Cetacean Research and Management 4(1):1-5.

Lee, J.S., S. Tanabe, H. Umino, R. Tatsukawa, T.R. Loughlin, and D.C. Calkins. 1996. Persistent Organochlorines in Steller Sea Lion (Eumetopias jubatus) from the Bulk of Alaska and the Bering Sea, 1976-1981." Marine Pollution Bulletin 32(7):535-545.

Lesage, V., C. Barrette, M.C.S. Kingsley, and B. Sjare. 1999. "The Effect of Vessel Noise on the Vocal Behavior of Belugas in the St. Lawrence River estuary Canada." Marine Mammal Science 15:65-84.

Loughlin, T.R., and A.E. Yorke. 2000. "Accounting for the Sources of Steller Sea Lion (Eumetopias jubatus) Mortality." Marine Fisheries Review 62(4):40-45. 
Lowry, L.F., K.J. Frost, R.A. Davis, D.P. DeMaster, and R.S. Suydam. 1998. "Movements and Behavior of Satellite-Tagged Spotted Seals (Phoca largha) in the Bering and Chukchi Seas." Polar Biology 19(4):221-230.

Lowry, L.F., B.V. Burkanov, K.J. Frost, M.A. Simpkins, R. Davis, D.P. DeMaster, R. Suydam and A. Springer. 2000a. "Habitat Use and Habitat Selection by Spotted Seals (Phoca largha) in the Bering Sea." Canadian Journal of Zoology 78:1959-1971.

Lowry, L.F., H.P. Huntington, R.H. Mattlin, and J.E. Reynolds III. 2000b. "Marine Mammal-Sea Ice Relationships." pp. 91-96 in H.P. Huntington (ed.), Impacts of Changes in Sea Ice and other Environmental Parameters in the Arctic: Report of the Marine Mammal Commission Workshop, Girdwood, Alaska. Marine Mammal Commission, Bethesda, Maryland.

Maldini, D., D. Calkins, S. Atkinson, and R. Meehan. 2005. Alaska Sea Otter Research Workshop: Addressing the Decline of the Southwestern Alaska Sea Otter Population. Pub. No. AK-SG-04-03, Sea Grant College Program, University of Alaska, Fairbanks.

Marine Mammal Commission. 2001. Annual Report to Congress 2000. Marine Mammal Commission, Bethesda, Maryland. Available at: http://www.mmc.gov/reports/annual/ (accessed on August 6, 2007).

Marine Mammal Commission. 2002. Annual Report to Congress 2001. Marine Mammal Commission, Bethesda, Maryland. Available at: http://www.mmc.gov/reports/annual/ (accessed on August 6, 2007).

Marine Mammal Commission. 2003. Annual Report to Congress 2002. Marine Mammal Commission, Bethesda, Maryland. Available at: http://www.mmc.gov/reports/annual/ (accessed on August 6, 2007).

Marine Mammal Commission. 2004. Annual Report to Congress 2003. Marine Mammal Commission, Bethesda, Maryland. Available at: http:/www.mmc.gov/reports/annual/ (accessed on August 6, 2007).

Marine Mammal Commission. 2005. Annual Report to Congress 2004. Marine Mammal Commission, Bethesda, Maryland. Available at: http://www.mmc.gov/reports/annual/ (accessed on August 6, 2007).

Marine Mammal Commission. 2006. Annual Report to Congress 2005. Marine Mammal Commission, Bethesda, Maryland. Available at: http://www.mmc.gov/reports/annual/ (accessed on August 6, 2007).

Matkin, C.O., L.B Lannaer, and G. Ellis. 2001. "Killer Whales and Predation on Steller Sea Lions." pp.61-67 in Steller Sea Lion Decline: Is It Food II. Alaska Sea Grant AK-SG-02-02, Fairbanks. 
McDonald, M.A., and S.E. Moore. 2002. "Calls Recorded from North Pacific Right Whales (Eubalaena japonica) in the Eastern Bering Sea." Journal of Cetacean Research and Management 4(3):261-266.

Merrick, R.L., and D.G. Calkins. 1996. "Importance of Juvenile Walleye Pollock, Theragra chalcogramma, in the Diet of Gulf of Alaska Steller Sea Lions, Eumetopias jubatus." in R. D. Brodeur, P.A. Livingston, T.R. Loughlin, and A.B. Hollowed (eds.), Ecology of Juvenile Walleye Pollock, Theragra chalcogramma. Workshop. U.S. Department of Commerce, National Oceanic and Atmospheric Administration, National Marine Fisheries Service, Seattle, Washington.

Merrick, R.L., M.K. Chumbley, and G.V. Byrd. 1997. "Diet Diversity of Steller Sea Lions (Eumetopias jubatus) and their Population Decline in Alaska: A Potential Relationship." Canadian Journal of Fisheries and Aquatic Science 54(6):1342-1348.

Minerals Management Service. 2006a. Biological Evaluation of the Potential Effects of Oil and Gas Leasing and Exploration in the Alaska OCS Beaufort Sea and Chukchi Sea Planning Areas on Endangered Bowhead Whales (Balaena mysticetus), Fin Whales (Balaenoptera physalis) and Humpback Whales (Megaptera novaeangeliae). U.S. Department of Interior, Mineral Management Service, Alaska OCS Region, Anchorage.

Minerals Management Service. 2006b. Final Study Plan for Estimating the Size of the Pacific Walrus Population. U.S. Fish and Wildlife Service, Marine Mammals Management; U.S. Geological Survey, Alaska Science Center; GiproRybFlot, Research and Engineering Institute for the Development and Operation of Fisheries; and ChukotTINRO, Pacific Research Institute of Fishes.

MMS. See Minerals Management Service.

Moore, S.E. 2000. "Provisional Estimates of Mysticete Whale Abundance on the Central Bering Sea Shelf, 1999." pp. 63-80 in A. Lopez and D.P. DeMaster (eds.), Marine Mammal Protection Act and Endangered Species Act Implementation Program 1999. National Marine Mammal Laboratory, Seattle, Washington.

Moore, S.E. 2002. "Cetacean Detection and Assessment Via Passive Acoustics, 2001." pp. 13-17 in A. Lopez and S.E. Moore (eds.), Marine Mammal Protection Act and Endangered Species Act Implementation Program 2001. National Marine Mammal Laboratory, Seattle, Washington.

Moore, S.E. 2005. "Long-Term Environmental Change and Marine Mammals." pp. 137-147 in J.E. Reynolds III, W.F. Perrin, R.R. Reeves, S. Montgomery, and T.J. Ragen (eds.), Marine Mammal Research: Conservation Beyond Crisis. Johns Hopkins University Press, Baltimore.

Moore, S. 2006. "Bering Climate-What Is Happening to Whales in the Bering Sea?" National Oceanic and Atmospheric Administration, National Marine Fisheries Service, Alaska Fisheries Science Center, Seattle, Washington. Available at: http://www.beringclimate.noaa.gov/ essays_moore.html (accessed August 5, 2007). 
Moore, S.E., and J.T. Clarke. 2002. "Potential Impact of Offshore Human Activities on Gray Whales (Eschrichtius robustus)." Journal of Cetacean Research and Management 4(1):19-25.

Moore, S.E., J.M. Waite, L.L. Mazzuca, and R.C. Hobbs. 2000. "Mysticete Whale Abundance and Observations of Prey Associations on the Central Bering Sea Shelf." Journal of Cetacean Research and Management 23:227-234.

Moore, S.E., J.R. Urban, W.L. Perryman, H.M. Perez-Cortez, P.R. Wade, L. Rojas-Bracho, and T. Rowles. 2001. "Are Gray Whales Hitting "K” Hard?" Marine Mammal Science 17(4):954-958.

Moore, S.E., J.M. Waite, N.A. Friday, and T. Honkalehto. 2002. "Distribution and Comparative Estimates of Cetacean Abundance on the Central and Southeastern Bering Sea Shelf with Observations on Bathymetric and Prey Associations." Progress in Oceanography 55: 249-262.

Moulton, V.D., W.J. Richardson, R.E. Elliott, T.L. McDonald, C. Nations, and M.T. Williams. 2003. "Effects of an Offshore Oil Development on Local Abundance and Distribution of Ringed Seals (Phoca hispida) of the Alaskan Beaufort Sea." In 15th Biennial Conference on the Biology of Marine Mammals, Greensboro, North Carolina. Society for Marine Mammalogy, Orlando, Florida.

National Marine Fisheries Service. 2001. Endangered Species Act-Section 7: Consultation Biological Opinion and Incidental Take Statement /Authorization of Bering Sea-Aleutian Islands Groundfish Fisheries based on the Fishery Management Plan for the Bering Sea-Aleutian Islands Groundfish. U.S. Department of Commerce, National Oceanic and Atmospheric Administration, National Marine Fisheries Service, Juneau.

National Marine Fisheries Service. 2003. Supplement to the Endangered Species Act-Section 7 Biological Opinion and Incidental Take Statement of October 2001. U.S. Department of Commerce, National Oceanic and Atmospheric Administration, National Marine Fisheries Service, Juneau.

National Marine Fisheries Service. 2005. EIS on Northern Right Whale Research: Scoping Meeting, San Diego, CA, December 10, 2005. U.S. Department of Commerce, National Oceanic and Atmospheric Administration, National Marine Fisheries Service. Available at: http://www.nmfs.noaa.gov/pr/pdfs/permits/eis_rightwhale_presentation.pdf (accessed August 5, 2007).

National Marine Fisheries Service. 2006a. Draft Recovery Plan for the Fin Whale (Balaenoptera physalus). National Marine Fisheries Service, Silver Springs, Maryland. Available at: http://www.nmfs.noaa.gov/pr/recovery/plans.htm (accessed on August 6, 2007).

National Marine Fisheries Service. 2006b. "North Pacific Right Whale" website. NMFS Alaska Regional Office. Available at: http://www.fakr.noaa.gov/protectedresources/whales/nright/default.htm (accessed on August 6, 2007). 
National Marine Fisheries Service. 2006c. Steller Sea Lion Designated Critical Habitat. U.S. Department of Commerce, National Oceanic and Atmospheric Administration, National Marine Fisheries Service. Available at:

http://www.fakr.noaa.gov/protectedresources/stellers/criticalhabitat_map.pdf (accessed August 5, 2007).

National Marine Mammals Laboratory. 2006. "National Marine Mammal Laboratory Library." Searchable database available at: http://www.afsc.noaa.gov/nmml/library/ (accessed on August 6, 2007).

National Oceanic and Atmospheric Administration. 2006a. Draft Recovery Plan for the Fin Whale (Balaenoptera physalus). U.S. Department of Commerce, National Oceanic and Atmospheric Administration, National Marine Fisheries Service, Office of Protected Resources, Silver Spring, Maryland.

National Oceanic and Atmospheric Administration. 2006b. Draft Steller Sea Lion Recovery Plan-Draft, First Revision. U.S. Department of Commerce, National Oceanic and Atmospheric Administration, National Marine Fisheries Service, Office of Protected Resources, Silver Spring, Maryland.

National Oceanic and Atmospheric Administration. 2006c. Protected Resources Division. Website. National Marine Fisheries Service, Alaska Regional Office. Available at: www.fakr.noaa.gov/protectedresources/ (accessed on August 6, 2007).

National Oceanic and Atmospheric Administration. 2006d. Steller Sea Lion Critical Habitat and No Entry Zones. Website. Available at: http:/www.fakr.noaa.gov/protectedresources/ stellers/habitat.htm (accessed on August 6, 2007).

NMFS. See National Marine Fisheries Service.

NOAA. See National Oceanic and Atmospheric Administration.

Nordeen, C., and J. Lien. 2001. "The Effects of High Amplitude Acoustic Deterrents on the Distribution, Abundance and Behaviour of Baleen Whales." 14th Biennial Conference on the Biology of Marine Mammals, Vancouver, Canada. Society for Marine Mammalogy, Orlando, Florida.

Pauly, D., A.W. Trites, E. Capuli, and V. Christensen. 1998. "Diet Composition and Trophic Levels of Marine Mammals.” ICES Journal of Marine Science 55:467-481.

Perryman, W.L., and M.S. Lynn. 2002. "Evaluation of Nutritive Condition and Reproductive Status of Migrating Gray Whales (Eschrichtius robustus) Based on Analysis of Photogrammetric Data." Journal of Cetacean Research and Management 4(2):155-164. 
Poole, D., and G.H. Givens. 2001. "An Explanatory Assessment of the Bering-Chukchi-Beaufort Seas of Bowhead Whales Using a Stochastic Population Model." Journal of Cetacean Research and Management 3(1):1-6.

Punt, A.E., and D.S. Butterworth. 1996. "Further Remarks on the Bayesian Approach for Assessing the Bering-Chukchi-Beaufort Seas Stock of Bowhead Whales." Report of the International Whaling Commission 46:481-491.

Punt, A.E., and D.S. Butterworth. 1997. "Assessments of the Bering-Chukchi-Beaufort Seas Stock of Bowhead Whales (Balaena mysticetus) Using Maximum Likelihood and Bayesian Methods." Report of the International Whaling Commission 47:603-618.

Punt, A.E., and D.S. Butterworth. 1999. "An Assessment of the Bering-Chukchi-Beaufort Seas Stock of Bowhead Whales (Balaena mysticetus) Using a Bayesian Approach.” Journal of Cetacean Research and Management (1):53-71.

Punt, A.E., and D.S. Butterworth. 2000. "Why Do Bayesian and Maximum Likelihood Assessments of the Bering-Chukchi Beaufort Seas Stock of Bowhead Whales Differ?" Journal of Cetacean Research and Management 2(2):125-133.

Punt, A.E., and D.S. Butterworth. 2002. "An Examination of Certain of the Assumptions Made in the Bayesian Approach Used to Assess the Eastern North Pacific Stock of Gray Whales (Eschrichtius robustus)." Journal of Cetacean Research and Management 4(1):99-110.

Punt, A.E, T. Polafcheck, and D.S. Butterworth. 1997. "Comparison of SLAs for the BeringChukchi-Beaufort Seas Stock of Bowhead Whales." Report to the International Whaling Commission 47:865-870.

Read, A.J., and P.R. Wade. 2000. "Status of Marine Mammals in the United States." Conservation Biology 14(4):929-940.

Ream, R.R., J.T. Sterling, and T.R. Loughlin. 2005. "Oceanographic Features Related to Northern Fur Seal Migratory Movements.” Deep-Sea Research II 52: 823-843.

Reeves, R.R., G.K. Silber, and P.M. Payne. 1998. Draft Recovery Plan for the Fin Whale Balaenoptera physalus and Sei Whale Balaenoptera borealis. U.S. Department of Commerce, National Oceanic and Atmospheric Administration, National Marine Fisheries Service, Office of Protected Resources, Silver Spring, Maryland.

Richardson, W.J. 1996. “Acoustic Effects on Bowhead Whales: Overview.” pp. 107-110 in Alaska OCS Region: Proceedings of the 1995 Arctic Synthesis Meeting, Anchorage, Alaska. U.S. Department of Interior, Minerals Management Service, Alaska OCS Region, Anchorage, Alaska.

Rugh, D.J., K.E.W. Shelden, and D. E. Withrow. 1997. "Spotted Seals, Phoca largha, in Alaska." Marine Fisheries Review 59(1):1-18. 
Rugh, D.J., M.M. Muto, S.E. Moore, and D.P. DeMaster. 1999. Status Review of the Eastern North Pacific Stock of Gray Whales. NOAA Technical Memorandum NMFS-AFSC-103. U.S. Department of Commerce, National Oceanic and Atmospheric Administration, National Marine Fisheries Service, Seattle, Washington.

Rugh, D.J., K.E.W. Shelden, and A. Schulman-Janiger. 2001. "Timing of the Gray Whale Southbound Migration." Journal of Cetacean Research and Management 3(1):31-39.

Schell, D.M. 2000. "Declining Carrying Capacity in the Bering Sea: Isotopic Evidence from Whale Baleen." Limnology and Oceanography 45:459-462.

Scribner, K.T., J. Bodkin, B. Ballachey, S.R. Fain, M.A. Cronin, and M. Sanchez. 1997. "Population Genetic Studies of the Sea Otter (Enhydra lutris): A Review and Interpretation of Available Data." pp. 197-208 in A.E. Dizon, S.J. Chivers, and W.F. Perrin (eds.), Molecular Genetics of Marine Mammals. Special Publication Number 3, Society for Marine Mammalogy, Lawrence, Kansas.

Seagars, D.J., and J. Garlich-Miller. 2001. "Organochlorine Compounds and Aliphatic Hydrocarbons in Pacific Walrus Blubber.” Marine Pollution Bulletin 43(1-6):122-131.

Sheffield, G., F.H. Fay and B.P. Kelly. 2001. "Laboratory Digestion of Prey and Interpretation of Walrus Stomach Contents.” Marine Mammal Science 17(2):310-330.

Shelden, K.E.W., and D.J. Rugh. 2002. The Bowhead Whale, Balaena mysticetus: Its Historic and Current Status. U.S. Department of Commerce, National Oceanic and Atmospheric Administration, National Marine Fisheries Service, National Marine Mammal Laboratory and Alaska Fisheries Science Center, Seattle, Washington.

Shelden, K.E.W., D.P. DeMaster, D.J. Rugh, and A.M. Olson. 2001. "Developing Classification Criteria under the U.S. Endangered Species Act: Bowhead Whales as a Case Study." Conservation Biology 15(5):1300-1307.

Shelden, K.E.W., S.E. Moore, J.M. Waite, P.R. Wade, and D.J. Rugh. 2005. "Historic and Current Habitat Use by North Pacific Right Whales Eubalaena japonica in the Bering Sea and Gulf of Alaska." Mammal Review 35(2): 129-155.

Shelden, K.E.W., S.E. Moore, J.M. Waite, P.R. Wade, and D.J. Rugh. 2006. North Pacific Right Whales, Eubalaena japonica, in the Eastern North Pacific. U.S. Department of Commerce, National Oceanic and Atmospheric Administration, National Marine Fisheries Service, National Marine Mammal Laboratory, Seattle, Washington.

Simpkins, M.A., L.M. Hiruki-Raring, G. Sheffield, J.M. Grebmeier, and J.L. Bengtson. 2003. "Habitat Selection by Ice-Associated Pinnipeds near St. Lawrence Island, Alaska in March 2001." Polar Biology 26(9):577-586. 
Sinclair, E.H, S.E. Moore, N.A. Friday, T.K. Zeppelin, J.M. Waite. 2005. "Do Patterns of Steller Sea Lion (Eumetopias jubatus) Diet, Population Trend and Cetacean Occurrence Reflect Oceanographic Domains from the Alaska Peninsula to the Central Aleutian Islands?" Fisheries Oceanography 14 (Suppl. 1):223-242.

Small, R.J. 2001. "Aerial Survey of Harbor Seals in Southern Bristol Bay, Alaska, 1998-1999." In Harbor Seal Investigations in Alaska, Alaska Department of Fish and Game, Anchorage.

Small, R.J., G.W. Pendleton, and K.W. Pitcher. 2003. "Trends in Abundance of Alaska Harbor Seals, 1983-2001." Marine Mammal Science 19(2):344-362.

Smultea, M.A., K.W. Koski, G.W. Miller, W.J. Richardson, and C.R. Greene, Jr. 1999. "Reactions of Seals to Underwater Playbacks of Drilling and Icebreaker Noise in the Alaskan Beaufort." Northwestern Naturalist 81(2):87-175.

Strick, J.M., L.W. Fritz, and J.P. Lewis. 1997. Aerial and Ship-based Surveys of Steller Sea Lions in southeast Alaska, the Gulf of Alaska, and Aleutian Islands during June and July 1994. NOAA Tech. Mem. NMFS-AFSC-71. U.S. Department of Interior, Fish and Wildlife Service and National Marine Fisheries Service, Alaska Fisheries Science Center, Seattle, Washington.

Taylor, M. 2003. "Why the Bering-Chukchi-Beaufort Seas Bowhead Whale Is Endangered: Response to Shelden et al." Conservation Biology 17(3):915-917.

Trites, A., and K. Heise. 1996. "Marine Mammals of the Alaska Gyre." pp. 25-30 in D. Pauly and V. Christensen (eds.), Mass-Balance Models of Northeastern Pacific Ecosystems. University of British Columbia, Fisheries Centre Research Reports 4(1).

Trites, A.W., S.K. Atkinson, D.P. DeMaster, L.W. Fritz, T.S. Gelatt, L.D. Rea, and K.M. Wynne. 2006. Sea Lions of the World. Pub. No. AK-SG-06-01. Sea Grant College Program, University of Alaska, Fairbanks.

Tynan, C.T. 1999. "Redistributions of Cetaceans in the Southeastern Bering Sea Relative to Anomalous Oceanographic Conditions during the 1997 El Niño." pp. 115-77 in H.J. Freeland, W.T. Peterson, and A. Tyler (eds.), Proceedings of the 1998 Science Board Symposium on the Impacts of the 1997/98 El Niño Event on the North Pacific Ocean and its Marginal Seas. North Pacific Marine Science Organization (PICES), Sidney, British Columbia.

UBC. See University of British Columbia.

USGS. See U.S. Geological Survey.

University of British Columbia. 1999. Ecosystem Change and the Decline of Marine Mammals in the Eastern Bering Sea: Testing the Ecosystem Shift and Commercial Whaling Hypotheses. Fisheries Centre Research Reports, Volume 7(1). University of British Columbia Fisheries Centre, Vancouver, British Columbia. 
U.S. Fish and Wildlife Service. 2006a. Endangered Species Listing Program. Website. Available at: http://alaska.fws.gov/fisheries/endangered/listing.htm (accessed on August 6, 2007).

U.S. Fish and Wildlife Service. 2006b. Marine Mammals Management. Website. Available at: http://alaska.fws.gov/fisheries/mmm/index.htm (accessed on August 6, 2007).

U.S. Fish and Wildlife Service. 2006c. Marine Mammals Management Marking, Tagging, and Reporting Program. Website. Available at:

http://alaska.fws.gov/fisheries/mmm/mtrp/mtrpmain.htm (accessed on August 6, 2007).

U.S. Fish and Wildlife Service. 2006d. Northern Sea Otter Species Profile. Website. Available at: http://ecos.fws.gov/speciesProfile/SpeciesReport.do?spcode=A0HK (accessed on August 6, 2007).

U.S. Geological Survey. 2004. Pacific Walrus International Database (PWID) Bering and Chukchi Sea Datasets. U.S. Department of Interior, U.S. Geological Survey, Alaska Science Center, Anchorage.

Wade, P.R. 1998. "Calculating Limits to the Allowable Human-Caused Mortality of Cetaceans and Pinnipeds." Marine Mammal Science 14(1):1-37.

Wade, P.R. 2002. "Bayesian Stock Assessment of the Eastern Pacific Gray Whale Using Abundance and Harvest Data from 1967-1996." Journal of Cetacean Research and Management 4(1):85-98.

Wade, P., M.P. Heide-Jørgensen, K. Shelden, J. Barlow, J. Carretta, J. Durban, R. LeDuc, L. Munger, S. Rankin, A. Sauter, and C. Stinchcomb. 2006. "Acoustic Detection and SatelliteTracking Leads to Discovery of Rare Concentration of Endangered North Pacific Right Whales." Biological Letters 2:417-419.

Waite, J.M. 1998. "Northern Right Whale Sighted off Alaska." Marine Mammal Society Newsletter 6(3):7.

Waite, J.M., N.A. Friday, and S.E. Moore. 2002. "Killer Whale (Orcinus orca) Distribution and Abundance in the Central and Southeastern Bering Sea, July 1999 and June 2000." Marine Mammal Science 18(3):779-786.

Weller, D.W., Y.V. Ivashchenko, G.A. Tsidulko, A.M. Burdin, and R.L. Brownell, Jr. 2002. Influence of Seismic Surveys on Western Gray Whales off Sakhalin Island, Russia in 2001. Paper $\mathrm{SC} / 54 / \mathrm{BRG} 14$, presented to International Whaling Commission Scientific Committee, Shimonoseki, Japan.

Wiggens, S.M., M.A. MacDonald, L.A. Munger, S.E. Moore, and J.A. Hildebrand. 2004. "Waveguide Propagation Allows Range Estimates for North Pacific Right Whales in the Bering Sea." Canadian Acoustics 32(2): 146-154. 
Winship, A.J., and A.W. Trites. 2006. "Risk of Extirpation of Steller Sea Lions in the Gulf of Alaska and Aleutian Islands: A Population Viability Analysis Based on Alternative Hypotheses for Why Sea Lions Declined in Western Alaska." Marine Mammal Science 22(1):124-155.

Winship, A.J, A.W. Trites, and D.G. Calkins. 2001. "Growth in Body Size of the Steller Sea Lion (Eumetopias jubatus).” Journal of Mammalogy 82(2):500-519.

Wolfe, R.J., and C. Mishler. 1996. The Subsistence Harvest of Harbor Seal and Sea Lion by Alaska Natives in 1995. Technical Paper No. 238. Alaska Department of Fish and Game, Division of Subsistence, Juneau.

Wolfe, R.J., and L.B. Hutchinson-Scarbrough. 1999. The Subsistence Harvest of Harbor Seals and Sea Lions by Alaska Natives in 1998. Technical Report 250. Alaska Department of Fish and Game, Division of Subsistence, Juneau, Alaska.

Wolfe, R.J, J.A, Fall, and R.T. Stanek. 2002. The Subsistence Harvest of Harbor Seals and Sea Lions by Alaska Natives in 2001. Technical Paper No. 273. Alaska Department of Fish and Game, Division of Subsistence, Juneau.

Wolfe, R.J, J.A, Fall, and R.T. Stanek. 2003. The Subsistence Harvest of Harbor Seals and Sea Lions by Alaska Natives in 2002. Technical Paper No. 277. Alaska Department of Fish and Game, Division of Subsistence, Juneau.

Wolfe, R.J, J.A. Fall, and R.T. Stanek. 2004. The Subsistence Harvest of Harbor Seals and Sea Lions by Alaska Natives in 2003. Technical Paper No. 291. Alaska Department of Fish and Game, Division of Subsistence, Juneau.

Wolfe, R.J, J.A. Fall, and R.T. Stanek. 2005. The Subsistence Harvest of Harbor Seals and Sea Lions by Alaska Natives in 2004. Technical Paper No. 303. Alaska Department of Fish and Game, Division of Subsistence, Juneau.

Zeh, J.E., D. Poole, G.W. Miller, W.R. Koski, L. Baraff, and D.J. Rugh. 2002. "Survival of Bowhead Whales, Balaena mysticetus, Estimated from 1981-1998 Photoidentification Data." Biometrics 58:832-840.

\subsection{SOCIOECONOMICS AND SUBSISTENCE}

Alaska Fisheries Science Center. 2006. "Outreach in Alaska Fishing Communities: A Pilot Project in Sand Point." AFSC Quarterly Research Reports April-June 2006. Available at: http://www.afsc.noaa.gov/quarterly/amj2006/items3.htm (accessed February 7, 2007). 
Bauman, M. 2006. "Fishermen in False Pass Look to Gain with Marketing Agreement." Alaska Journal of Commerce. October 29, 2006. Available at:

http://www.alaskajournal.com/stories/102906/hom_20061029054.shtml (accessed

February 7, 2007).

Black, L.T., S. McGowan, J. Jacka, N. Taksami, and M. Wright. 1999. The History and Ethnohistory of the Aleutians East Borough. University of Alaska Press, Fairbanks.

BBNA. See Bristol Bay Native Association.

Bristol Bay Native Association. 2005. Community Profile: Naknek. Website. Available at: http://www.bbna.com/villages/snaknek/snaknek1b.htm (accessed February 7, 2007).

Bristol Bay Native Association. 2006. Resolution 1006-37. Website. Available at: http://www.renewableresourcescoalition.org/BBNA_resolution.pdf (accessed February 7, 2007).

Commercial Fishery Entry Commission. 2005. 2005 Permit and Fishing Activity by Year, State, Census Area, or City. Available at: http://www.cfec.state.ak.us/gpbycen/2005/mnu.htm (accessed February 7, 2007).

Cournia, L. 2006. "Boat Harbor Construction Begins in False Pass." Kodiak Daily Mirror, July 18, 2006.

Crowell, A.L., A.F. Steffian, and GL. Pullar. 2001. Looking Both Ways - Heritage and Identity of the Alutiiq People. University of Alaska Press, Fairbanks.

Department of Commerce, Community and Economic Development - Alaska Economic Information System. No date. Bristol Bay Census Area: Subsistence. Website. Available at: http://www.dced.state.ak.us/dca/AEIS/AEISMainFrame.cfm?CensusArea= Bristol\&Industry=Subsistence \&IndexItem=SubsistenceOverview (accessed February 7, 2007).

Department of Commerce, Community and Economic Development - Alaska Economic Information System. No date. Bristol Bay Census Area: Tourism. Website. Available at: http://www.dced.state.ak.us/dca/AEIS/AEISMainFrame.cfm?CensusArea= Bristol\&Industry=Tourism\&IndexItem=TourismOverview (accessed February 7, 2007).

Department of Economic and Community Development. No date. King Salmon, Alaska. Website. Available at: http://www.alaskatravel.com/alaska/king-salmon.html (accessed February 7, 2007).

Harbanuk, S. No date. Bristol Bay CRSA Coastal Management Plan Final Draft Plan Amendment. Appendix L: Community Profiles. Available at: http://www.dnr.state.ak.us/acmp/District/FinalFinalPlans/BristolBay/ BB_Appendix_L_CommunityProfiles.pdf (accessed February 7, 2007). 
Harbanuk, S. 2005. Appendix A: Aleutians East Borough Community Profiles. Alaska Department of Natural Resources. Available at: http://www.dnr.state.ak.us/acmp/District/ FinalPlans/AleutiansEast/AEB_Appendix_A_Community\%20profile.pdf (accessed February 7, 2007).

IAI. See Impact Assessment Inc.

Impact Assessment Inc. 2005. The Effects and Implications for Local Communities of the Oil Spill Resulting from the Sinking of the Selendang Ayu. Preliminary Overview of the Sequence of Events Leading up to and Following the Grounding of the Malaysia-Registered Freighter off the Coast of Unalaska Island. Prepared for the U.S. Department of Interior, Minerals Management Service, Alaska OCS Region. La Jolla, California.

Impact Assessment Inc. 2007. Summary of Socioeconomic Trends and Current Conditions in the North Aleutian Basin Planning Area. Prepared for the U.S. Department of Interior, Minerals Management Service, Alaska OCS Region. La Jolla, California.

Northern Dynasty Mines. No date. Pebble Project: What is the Pebble Project? Available at: http://www.ndmpebblemine.com/ (accessed February 7, 2007).

Northern Economics Inc. and EDAW Inc. 2001. Sector and Regional Profiles of the North Pacific Groundfish Fisheries-2001. SSL-Social Impact Assessment, Appendix F. Available at: http://www.fakr.noaa.gov/sustainablefisheries/seis/sslpm/final/appendix_f.pdf (accessed February 7, 2007).

Nuka Research and Planning Group, LLC. 2005. An Overview of the Major Commercial Fisheries in the Unalaska Area that may Be Impacted by the M/V Selendang Ayu Oil Spill. Report to the Fisheries Work Group. Compiled at the request of the Alaska Department of Environmental Conservation (NTP 1880032807B) to support decision-making during the M/V Selendang Ayu oil spill response. Seldovia, Alaska.

Sepez, J.A., B.D. Tilt, C.L. Package, H.M. Lazarus, and I. Vaccaro. 2005. Community Profiles for North Pacific Fisheries - Alaska. NOAA Technical Memorandum NMFS-AFSC-160. Available at: http://www.afsc.noaa.gov/Publications/AFSC-TM/NOAA-TM-AFSC-160/NOAATM-AFSC-160.pdf (accessed February 7, 2007).

Southwest Alaska Municipal Conference. 2005. Chapter 9.0, Southwest Alaska Regional Economy. Available at: http://www.swamc.org/economics/09-SWRegionalEconomy.pdf (accessed February 7, 2007). 
Southwest Alaska Municipal Conference. 2006. Southwest Alaska Comprehensive Economic Development Strategy Annual Update 2006. Prepared for the U.S. Department of Commerce Economic Development Administration, Alaska Department of Community and Economic Development, Division of Community Advocacy. Available at:

http://electra.he.net/ swamc/images/stories/pdf/ceds_06_update_swamc.pdf (accessed February 7, 2007).

U.S. Army Corps of Engineers. 1997. Navigation Improvements, Detailed Project Report and Environmental Assessment: King Cove, Alaska. U.S. Army Corps of Engineers, U.S. Army Engineer District, Alaska; Elmendorf Air Force Base, Alaska.

U.S. Army Corps of Engineers. 1998. Harbor Improvements, Feasibility Report and Environmental Assessment: Sand Point, Alaska. U.S. Army Corps of Engineers, U.S. Army Engineer District, Alaska; Elmendorf Air Force Base, Alaska. 